University of Louisville

ThinkIR: The University of Louisville's Institutional Repository

Electronic Theses and Dissertations

8-2011

\title{
Power in plaster : the installation of stuccowork during the late antique and early Byzantine periods.
}

Kaelin Merritt Jewell

University of Louisville

Follow this and additional works at: https://ir.library.louisville.edu/etd

\section{Recommended Citation}

Jewell, Kaelin Merritt, "Power in plaster : the installation of stuccowork during the late antique and early Byzantine periods." (2011). Electronic Theses and Dissertations. Paper 685.

https://doi.org/10.18297/etd/685

This Master's Thesis is brought to you for free and open access by ThinkIR: The University of Louisville's Institutional Repository. It has been accepted for inclusion in Electronic Theses and Dissertations by an authorized administrator of ThinkIR: The University of Louisville's Institutional Repository. This title appears here courtesy of the author, who has retained all other copyrights. For more information, please contact thinkir@louisville.edu. 
POWER IN PLASTER: THE INSTALLATION OF STUCCOWORK DURING THE LATE ANTIQUE AND EARLY BYZANTINE PERIODS

\author{
By \\ Kaelin Merritt Jewell \\ B.A., University of Louisville, 2006 \\ B.F.A., University of Louisville, 2006 \\ A Thesis \\ Submitted to the Faculty of the \\ College of Arts and Sciences of the University of Louisville \\ in Partial Fulfillment of the Requirements \\ for the Degree of \\ Master of Arts \\ Department of Art History \\ University of Louisville \\ Louisville, Kentucky
}

August 2011 
Copyright 2011 by Kaelin Merritt Jewell

All rights reserved 
POWER IN PLASTER: THE INSTALLATION OF STUCCOWORK DURING THE LATE ANTIQUE AND EARLY BYZANTINE PERIODS

By

Kaelin Merritt Jewell

B.A., University of Louisville, 2006

B.F.A., University of Louisville, 2006

A Thesis Approved on

August 5, 2011

by the following Thesis Committee:

Thesis Director (Karen C. Britt)

Linda Marie Gigante

Blake Beattie 


\section{ACKNOWLEDGEMENTS}

I would like to thank my mentor, Dr. Karen Britt, for her support, guidance, and encouragement during the thesis writing process. Also, I would like to thank the members of my thesis committee, Dr. Linda Gigante and Dr. Blake Beattie, for their thoughtful comments and participation in my thesis defense.

For their unwavering support of my education, I would like to thank my parents, Mary and Thomas Jewell. In addition, I want to acknowledge the help and inspiration of GAC and ABL, whose intelligence and laughter provided me with an invaluable source of strength. 


\title{
ABSTRACT \\ POWER IN PLASTER: THE INSTALLATION OF STUCCOWORK DURING THE LATE ANTIQUE AND EARLY BYZANTINE PERIODS
}

\author{
Kaelin M. Jewell
}

August 5, 2011

This thesis traces the evolution of trends in stucco decoration during the late antique and early Byzantine periods. The focus of the thesis is to identify and explain the transition between the figural stuccowork trends of the fifth century and the non-figural stuccowork trends of the sixth century. The results of a survey taken of extant late antique and early Byzantine stuccowork of Italy, Istria, and Constantinople, indicate that figural stuccowork was confined to the Italian peninsula with a terminus ante quem of $473 \mathrm{CE} .^{1}$ As a whole, the stuccowork of the sixth century was conspicuously non-figural in its design and could be found in all three geographical areas. This data shows that there was a stylistic shift in stuccowork trends between the late fifth and early sixth centuries, but how should this shift be interpreted? This thesis proposes that the figural stuccoes of the fifth century be seen as classicizing elements that were installed by the bishops of the Italian peninsula in order to establish their ties to Imperial Rome. Moreover, the transition to non-figural stuccowork during the sixth century should been seen as a result of Constantinopolitan influence.

\footnotetext{
${ }^{1}$ This date corresponds to the death of Bishop Neon, the patron responsible for the monumental figural stuccoes of the Neonian Baptistery in Ravenna.
} 
TABLE OF CONTENTS

PAGE

ACKNOWLEDGMENTS ..............................................................

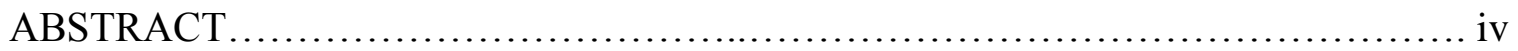

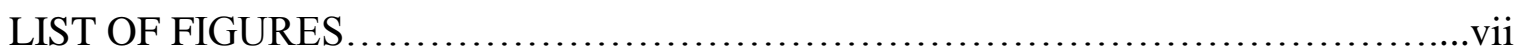

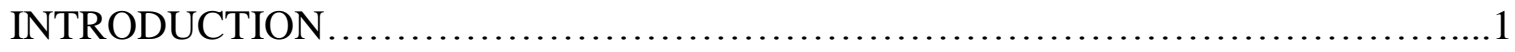

1. HISTORIOGRAPHY OF STUCCOWORK.........................................

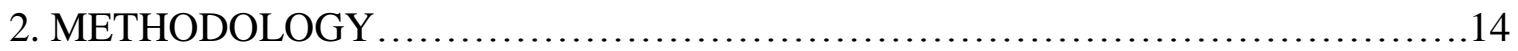

3. STUCCO AS MATERIAL: THE PRODUCTION AND INSTALLATION OF STUCCOWORK DURING THE ROMAN PERIOD ............................... 18

4. SHIFTING WESTERN CAPITALS: ROME, MILAN, AND RAVENNA............ 28

Constantine and Rome in the Fourth Century.................................29

Ambrose and Milan in the Fourth Century.................................. 33

Ravenna in the Fifth Century........................................... 37

Sixtus III and his "Renaissance".......................................... 41

5. CLASSICIZING PLASTER: STUCCOWORK FROM THE FOURTH AND FIFTH CENTURIES IN ROME, MILAN, AND RAVENNA.............................. 45

San Lorenzo, Milan..........................................................

Santa Maria Maggiore, Rome............................................48

Mausoleum of Quirinus of Sescia, San Sebastiano, Rome...................... 50

Ursiana Cathedral, Ravenna............................................ 52 
Santa Croce and the so-called Mausoleum of Galla Placidia, Ravenna.

Neonian (Orthodox) Baptistery, Ravenna.

6. FROM GOTHS TO BYZANTINES: ITALY AND ISTRIA DURING THE SIXTH CENTURY ............................................................65

Theoderic and Ostrogothic Italy...................................... 65

Justinian and Early Byzantine Italy.................................. 72

Early Byzantine Ravenna and the Istrian Peninsula........................ 75

7. EARLY BYZANTINE STUCCOWORK FROM THE SIXTH CENTURY IN ITALY AND ISTRIA .......................................................... 78

Santa Maria in Cosmedin, Rome......................................... 78

San Vitale, Ravenna.............................................. 80

Santa Maria delle Grazie, Grado......................................... 86

Basilica Eufrasiana and the Episcopal Palace Complex, Poreč...............87

Chapel of Santa Maria del Canneto, Santa Maria Formosa, Pula............... 89

Hagia Sophia, Constantinople......................................... 91

8. LOMBARD AND UMAYYAD STUCCOWORK: REVISITING THE PAST?.........94

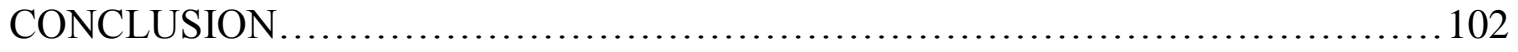

REFERENCES........................................................ 105

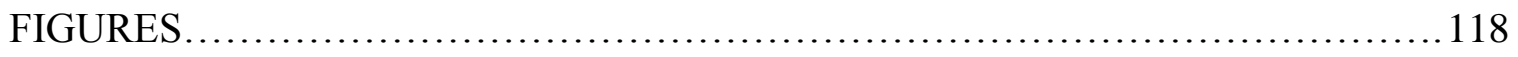

APPENDIX ............................................................ 167

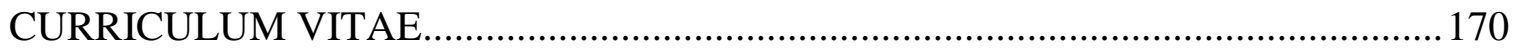




\section{LIST OF FIGURES}

\section{FIGURE}

1. A soldier chopping lime; detail from Trajan's Column, Rome, 113 CE; Ling (1976): fig. 340.

2. Plaster trowels and floats from Roman fort at Saalburg, Germany; Ling (1976): fig. 346.

3. Temple of Portunus, Rome, c. 75 BCE; ARTstor

4. Stucco fluting on a brick-faced column, House of the Gem at Herculaneum, before 79 CE; Ling (1976): fig. 342.

5. Stuccoed Columns at Neonian Baptistery, Ravenna, 450-473 CE; ARTstor

6. Stuccoed capitals from Herculaneum, before 79 CE; Ling (1976): fig. 341.

7. Double-sided bronze tool from tomb at Pozzuoli, Italy, $1^{\text {st }}$ to $2^{\text {nd }}$ c. CE; fig. 355.

8. Plan of hypogeum (Underground Basilica), Rome, mid- $1^{\text {st }}$ c. CE; Strong and Jolliffe (1924): 67.

9. Interior of hypogeum (Underground Basilica), Rome, mid- $1^{\text {st }}$ c. CE; Strong and Jolliffe (1924): pl. II

10. Map of late-fourth century Milan; Christie (2006): 109.

11. Map of Ravenna, c. 200 CE; Deliyannis (2010): 22.

12. Map of Ravenna, c. 480 CE; Deliyannis (2010):42.

13. Interior of Santa Maria Maggiore, Rome, c. 432-440 CE; ARTstor.

14. Interior of Santa Sabina, Rome, c. 422-432 CE; ARTstor.

15. Plan of San Lorenzo, late- $4^{\text {th }}$ to early-5 $5^{\text {th }}$ century CE; ARTstor.

16. Stucco fragment, arch soffit north of entrance to Sant'Hippolytus chapel, San Lorenzo, Milan, late- $4^{\text {th }}$ C. CE; Pasquini (2002): 234. 
17. Stucco fragment, cornice, Sant'Aquilino chapel, San Lorenzo, Milan, late- $4^{\text {th }}$ to early$5^{\text {th }}$ c. CE; Pasquini (2002): 234.

18. Stucco fragment, frieze, Santa Maria Maggiore, Rome, 432-440 CE; Pasquini (2002): 196.

19. Reconstruction of San Sebastiano, Rome, $4^{\text {th }}$ century CE; ARTstor

20. Plan of San Sebastiano, Rome, $4^{\text {th }}$ century CE and later; Krautheimer (1937-1977): vol. V pl. VII

21. View facing east, Mausoleum of Quirinus, San Sebastiano, Rome, c. $4^{\text {th }}$ century CE with c. $5^{\text {th }}$ century CE decoration; Krautheimer (1937-1977): 138.

22. Niche \#12 stucco decoration, Mausoleum of Quirinus, San Sebastiano, Rome, c. $5^{\text {th }}$ century CE; Pasquini (2002): 199.

23. Soffit of niche arcade, Mausoleum of Quirinus, San Sebastiano, Rome, c. $5^{\text {th }}$ century CE; Pasquini (2002): 198.

24. Upper part of an unidentified niche, Mausoleum of Quirinus, San Sebastiano, Rome, c. $5^{\text {th }}$ century CE; Pasquini (2002): 199.

25. Niche \#7 stucco decoration, Mausoleum of Quirinus, San Sebastiano, Rome, c. $5^{\text {th }}$ century CE; Pasquini (2002): 198.

26. Standing figure, Tomb of the Valerii (Tomb H), Vatican Necropolis, Rome, 160 CE; Allag and Blanc (2006): 108.

27. Plan of Ursiana Cathedral, Ravenna, c. 405-431 CE; Cirelli (2008): 73.

28. Plan of Santa Croce, Ravenna, after 425 CE; Deliyannis (2010): 71.

29. Interior of so-called Mausoleum of Galla Placidia, Ravenna, after 425 CE; ARTstor

30. Cornice fragments, Santa Croce, Ravenna, after 425 CE; Pasquini (2002): 121.

31. Column fragments, Santa Croce, Ravenna, after 425 CE; Pasquini (2002): 121.

32. Human and quadruped fragments, Santa Croce, Ravenna, after 425 CE; Pasquini (2002): 125.

33. Plan of Neonian Baptistery, Ravenna, c. 431-450 CE; Deliyannis (2010): 90. 
34. Elevation of Neonian Baptistery, Ursian and Neonian periods, Ravenna, c. 405-473 CE; Deliyannis (2010): 92.

35. Interior of Neonian Baptistery, Ravenna, c. 450-473 CE; ARTstor.

36. Stucco decoration, general view, Neonian Baptistery, Ravenna, c. 450-473 CE; ARTstor.

37. Schematic drawing of stuccowork program, Neonian Baptistery, Ravenna, c. 450-473

CE; Kostof (1965): fig. 41.

38. View of soffits, Neonian Baptistery, Ravenna, c. 450-473 CE

39. Niche 1, Neonian Baptistery, Ravenna, c. 450-473 CE; Kostof (1965): fig. 83.

40. Niche 2, Neonian Baptistery, Ravenna, c. 450-473 CE; Kostof (1965): fig. 85.

41. Niche 3, Neonian Baptistery, Ravenna, c. 450-473 CE; Kostof (1965): fig. 86.

42. Niche 4, Neonian Baptistery, Ravenna, c. 450-473 CE; Kostof (1965): fig. 87.

43. Niche 5, Neonian Baptistery, Ravenna, c. 450-473 CE; Kostof (1965): fig. 89.

44. Niche 6, Neonian Baptistery, Ravenna, c. 450-473 CE; Kostof (1965): fig. 90.

45. Niche 7, Neonian Baptistery, Ravenna, c. 450-473 CE; Kostof (1965): fig. 91.

46. Niche 8, Neonian Baptistery, Ravenna, c. 450-473 CE; Kostof (1965): fig. 93.

47. Niche 9, Neonian Baptistery, Ravenna, c. 450-473 CE; Kostof (1965): fig. 94.

48. Niche 10, Neonian Baptistery, Ravenna, c. 450-473 CE; Kostof (1965): fig. 95.

49. Niche 11, Neonian Baptistery, Ravenna, c. 450-473 CE; Kostof (1965): fig. 96.

50. Niche 12, Neonian Baptistery, Ravenna, c. 450-473 CE; Kostof (1965): fig. 97.

51. Niche 13, Neonian Baptistery, Ravenna, c. 450-473 CE; Kostof (1965): fig. 98.

52. Niche 14, Neonian Baptistery, Ravenna, c. 450-473 CE; Kostof (1965): fig. 99.

53. Niche 15, Neonian Baptistery, Ravenna, c. 450-473 CE; Kostof (1965): fig. 101.

54. Niche 16, Neonian Baptistery, Ravenna, c. 450-473 CE; Kostof (1965): fig. 102. 
55. Goats, above Niche 1, Neonian Baptistery, Ravenna, c. 450-473 CE; Kostof (1965): fig. 78.

56. Jonah and the Whale, above Niche 12, Neonian Baptistery, Ravenna, c. 450-473 CE; Kostof (1965): fig. 79.

57. Christ trampling the lion and adder, above Niche 13, Neonian Baptistery, Ravenna, c. 450-473 CE; Kostof (1965): fig. 80.

58. Traditio Legis, above Niche 14, Neonian Baptistery, Ravenna, c. 450-473 CE; Kostof (1965): fig. 81.

59. Daniel and the Lion's Den, above Niche 15, Neonian Baptistery, Ravenna, c. 450-473

CE; Kostof (1965): fig. 82.

60. Interior of Red Monastery, Sohag, Egypt, c. 525 CE;

http://alumnews.blogs.brynmawr.edu/2011/04/21/elizabeth-bolman-guggenheim/

61. Christ militans, Archiepiscopal Chapel, Ravenna, c. 494-519 CE; ARTstor.

62. Tubi fittili and pumice blocks, Neonian Baptistery, Ravenna, c. 450-473; Kostof (1965): fig. 29.

63. Jonathan Bardill's reconstruction of St. Polyeuktos, Constantinople, 524-527 CE; Bardill (2006): 363.

64. Map of Istria; Bratož (2009): 12.

65. Plan of Santa Maria in Cosmedin, Rome, after 536 CE; Krautheimer (1937-1977): v. II pl. XX.

66. Elevation and plan of loggia, Santa Maria in Cosmedin, Rome, after 536 CE; Krautheimer (1937-1977): v. II 292.

67. Soffit 1; loggia of Santa Maria in Cosmedin, Rome, after 536 CE; Pasquini (2002): 197.

68. Soffit 2; loggia of Santa Maria in Cosmedin, Rome, after 536 CE; Pasquini (2002): 197.

69. Plan and map of San Vitale and surrounding church complexes, Ravenna, c. 527-547 CE; Cirelli (2008): 101.

70. Sculptural fragments, St. Polyeuktos, Constantinople, 524-527 CE; Harrison (1986): 37. 
71. Reconstruction of marble revetment, San Vitale, Ravenna, c. 527-547 CE; Deliyannis (2010): 235.

72. Presbytery mosaics, San Vitale, Ravenna, c. 527-547 CE; Photograph by author.

73. Southern vestibule, San Vitale, Ravenna, c. 527-547 CE; Pasquini (2002): 166.

74. Southern vestibule barrel vault, San Vitale, Ravenna, c. 527-547 CE; Pasquini (2002): 167.

75. Old Testament Scenes, South Wall, Presbytery, San Vitale, Ravenna, c. 527-547 CE; Photograph by author.

76. Northern vestibule arcade soffits, San Vitale, Ravenna, c. 527-547 CE; Pasquini (2002): 153.

77. Central soffit, northern vestibule arcade, San Vitale, Ravenna, c. 527-547 CE;

Pasquini (2002): 156.

78. Lateral soffit 1, northern vestibule arcade, San Vitale, Ravenna, c. 527-547 CE; Pasquini (2002): 154.

79. Lateral soffit 2, northern vestibule arcade, San Vitale, Ravenna, c. 527-547 CE; Pasquini (2002): 155.

80. Central Soffit, North triforium of presbytery, San Vitale, Ravenna, c. 527-547 CE; Pasquini (2002): 150.

81. South triforium of presbytery, San Vitale, Ravenna, c. 527-547 CE; Pasquini (2002): 147.

82. Sasanian textile fragment, now at Aachen Cathedral; Harrison (1986): 125.

83. Apse window, Santa Maria delle Grazie, Grado, c. 571-587 CE; Pasquini (2002): 176.

84. Soffit 1, Basilica Eufrasiana, Poreč, mid-6 ${ }^{\text {th }}$ c. CE; Pasquini (2002): 178.

85. Soffit 2, Basilica Eufrasiana, Poreč, mid-6 ${ }^{\text {th }}$ c. CE; Pasquini (2002): 180.

86. Soffit 3, Basilica Eufrasiana, Poreč, mid-6 ${ }^{\text {th }}$ c. CE; Pasquini (2002): 181.

87. Soffit 4, Basilica Eufrasiana, Poreč, mid-6 ${ }^{\text {th }}$ c. CE; Pasquini (2002): 182.

88. Soffit 5, Basilica Eufrasiana, Poreč, mid-6 ${ }^{\text {th }}$ c. CE; Pasquini (2002): 183.

89. Soffit 6, Basilica Eufrasiana, Poreč, mid-6 ${ }^{\text {th }}$ c. CE; Pasquini (2002): 185. 
90. Soffit 7, Basilica Eufrasiana, Poreč, mid-6 ${ }^{\text {th }}$ c. CE; Pasquini (2002): 186.

91. Soffit 8, Basilica Eufrasiana, Poreč, mid- $6^{\text {th }}$ c. CE; Pasquini (2002): 187.

92. Soffit 9, Basilica Eufrasiana, Poreč, mid-6 ${ }^{\text {th }}$ c. CE; Pasquini (2002): 188.

93. Soffit 10, Basilica Eufrasiana, Poreč, mid-6 ${ }^{\text {th }}$ c. CE; Pasquini (2002): 190.

94. Western window, Basilica Eufrasiana, Poreč, mid-6 ${ }^{\text {th }}$ c. CE; Matejčić (2006): 126.

95. Cornice, apse, Basilica Eufrasiana, Poreč, mid-6 ${ }^{\text {th }}$ c. CE; Matejčić (2006): 126.

96. Episcopal palace complex, Poreč, mid-6 ${ }^{\text {th }}$ c. CE; Pasquini (2002): Matejčić (2006): 126.

97. Plan, Santa Maria Formosa complex, Pula, c. 546-557 CE; Mackie (2003): fig. 34.

98. Exterior view, Chapel of Santa Maria del Canneto, Santa Maria Formosa complex, Pula, c. 546-557 CE; Mackie (2003): fig. 35.

99. Vault, Chapel of Santa Maria del Canneto, Santa Maria Formosa complex, Pula, c. 546-557; Matejčić (2006): 131.

100. Southwestern vestibule, Hagia Sophia, Constantinople, c. 532-537 CE

101. Plan, Tempietto Longobardo, Cividale, c. 752-755 CE; Codini (2002): 101.

102. Reconstruction of original aula decoration, Tempietto Longobardo, Cividale, c. 752755 CE; Siena (2002): 249.

103. Western wall of aula, Tempietto Longobardo, Cividale, c. 752-755 CE; ARTstor.

104. Detail of standing figures, Tempietto Longobardo, Cividale, c. 752-755 CE;

Pasquini (2002): 208.

105. Vault stuccowork decoration, Khirbat al-Mafjar, c. 724-743 CE; ARTstor.

106. Reconstruction of stuccowork program at Khirbat al-Mafjar, c. 724-743 CE;

ARTstor.

107. Façade, Quasr al-Hayr, c. 724-743 CE; ARTstor.

108. Façade detail, Qasr al-Hayr West, c. 724-743 CE; ARTstor. 


\section{INTRODUCTION}

The decorative programs of late antique and early Byzantine ecclesiastical architecture have earned their share of scholarly attention with a significant emphasis placed on the study of frescoes and mosaics. Recently, increased attention has been paid to less conspicuous areas of these buildings. Scholars have begun to consider opus sectile, ${ }^{l}$ marble revetment, and stuccowork in their evaluations of architectural decoration in an effort to expand our understanding of how these monuments were visually experienced in antiquity. The most enigmatic material used in late antique and early Byzantine architectural decoration is stucco. This less costly material appeared in the most lavish late antique and early Byzantine monuments and seamlessly mingled with mosaic, marble, and other more expensive materials. The stylistic differences that are present in the stuccowork of these two periods are reflections of an underlying political agenda that was associated with the assertion of authority. In this thesis, I trace these stylistic differences in an effort to identify and explain the transition between the figural stuccowork trends of the fifth century and the tendency towards non-figural stuccowork of the sixth century.

This study is divided into eight chapters. The thesis begins with a survey of the history of scholarship on the stuccowork of Italy, Istria, and Constantinople, and includes

\footnotetext{
${ }^{1}$ Decorative marble inlay, often intricate, occurring on the floors and walls of late antique and early Byzantine churches. See L. James, "opus sectile." In The Oxford Companion to Western Art, Hugh Brigstocke, ed., (Oxford Art Online, http://www.oxfordartonline.com).
} 
material from the Roman, late antique, early Byzantine, Lombard, and Umayyad periods. Chapter 2 outlines the results of a survey taken of stuccowork remains from late antique and early Byzantine Italy, Istria, and Constantinople. The following chapter includes a discussion of the physical composition of stuccowork as well as an examination of the production and installation of the material during the Roman period, which is essential to an understanding of how the material was used during later periods. Chapter 4 presents the historical context for late antique Italy in order to provide the framework upon which the discussion of chapter 5's stuccowork is based. Chapter 5 presents a detailed examination of late antique stucco in Italy. This evidence suggests that the installation of classicizing stuccowork, along with other forms of architectural decoration, was used by bishops to exert their political authority by aligning their building programs with past emperors. The following two chapters focus on the historical context and stuccowork of the early Byzantine period. There is an observable stylistic shift in stuccowork that occurred between the late antique and early Byzantine periods, that is marked by the abandonment of figural stuccowork in favor of non-figural motifs that were directly influenced by Constantinopolitan trends. Chapter 6 will demonstrate how this stylistic shift was used as an effective tool for promoting the newly reestablished Byzantine authority on the Italian and Istrian peninsulas. Lastly, I will conclude this study with a brief examination of Lombard and Umayyad stuccowork in an effort to support the hypothesis that stuccowork, like other forms of architectural decoration, was used to exert political authority. 


\section{CHAPTER 1}

\section{HISTORIOGRAPHY OF STUCCOWORK}

In this chapter, a chronological approach will be taken in order to understand fully the framework within which current scholarship on late antique and early Byzantine stucco is situated. Stuccowork from the Roman period is widely extant and, therefore, has been the focus of scholarly investigation for decades. The earliest scholarship comes in the form of museum catalog entries, the earliest of which is found in the Bulletin of the Art Institute in Chicago and is entitled, "Stucco Reliefs from Nero's Palace” (1923). This entry provides a brief historical background and formal analysis of two stucco reliefs brought to the museum from Nero's Domus Aurea. ${ }^{2}$ In 1924, A.W. Van Buren wrote an article that described the technique of the stucco ceilings of Pompeii. ${ }^{3}$ In this article, Van Buren investigated the work of the first century architect Vitruvius in an effort to catalogue surviving evidence of the wooden frameworks that supported the non-figural stucco ceilings of Pompeiian houses. Van Buren's methodology, which considered textual sources and material evidence, broke with earlier, strictly formal, analysis and led to an increased interest in a synoptic approach to the study of Roman architectural decoration. That same year, Emily L. Wadsworth published a detailed study of Roman

\footnotetext{
${ }^{2}$ M.B.W., "Stucco Reliefs from Nero's Palace," Bulletin of the Art Institute of Chicago 17:2 (Feb., 1923): 15-16.

${ }^{3}$ A.W. Van Buren, "The Technique of Stucco Ceilings at Pompeii," The Journal of Roman Studies 14 (1924): 112-122.
} 
stucco entitled, "Stucco reliefs of the first and second centuries still extant in Rome."4 Wadsworth's monograph includes detailed discussions of stucco reliefs from eighteen different monuments in Rome that date from the late Republican period to the second century CE. Wadsworth contextualized the figural stuccoes within the textual and archaeological evidence. This study also includes a discussion of the origins of this particular type of Roman stucco relief, which is characterized by a free-form application, in which Wadsworth proposed a connection to Alexandria. ${ }^{5}$ However, Wadsworth admits that this connection is tenuous due to an absence of surviving stucco evidence in both textual and archaeological contexts. ${ }^{6}$

For the next forty years or so, English-language scholarship on Roman stucco was nearly nonexistent. However, beginning in the 1960s, there was renewed interest in the subject. In addition to Michael Cheilik's PhD dissertation entitled, “Opus Albarium: A Chronology of Roman Stucco Reliefs in Italy" (1965), Roger Ling wrote a series of articles dedicated to the investigation of all aspects of Roman stucco that were compiled into an anthology entitled, Stuccowork and Painting in Roman Italy (1999). ${ }^{7}$ One article, originally published in 1972, continues the work of Wadsworth with an investigation of pre-Augustan Italian stuccoes. ${ }^{8}$ These stuccoes, similar in design to other forms of architectural decoration such as opus sectile and mosaic, covered the vaults of Republican period tombs and bath complexes. Ling's analysis of the so-called "coffer

\footnotetext{
${ }^{4}$ E.L. Wadsworth, "Stucco reliefs of the first and second centuries still extant in Rome," Memoirs of the American Academy in Rome 4 (1924): 9-102.

${ }^{5}$ Ibid., 12.

${ }^{6}$ Ibid., 12.

${ }^{7}$ Michael Cheilik, "Opus Albarium: A Chronology of Roman Stucco Reliefs in Italy" (PhD diss., Johns Hopkins University, 1965); and Roger Ling, Stuccowork and Painting in Roman Italy. (Aldershot: Ashgate Publishing Company, 1999).

${ }^{8}$ Ling, "Stucco decoration in pre-Augustan Italy," originally published in the Papers of the British School at Rome v. 40 (1972): 11-58; reprinted in Stuccowork and Painting in Roman Italy. (Aldershot: Ashgate Publishing Company, 1999).
} 
style" provided a much needed study of the non-figural stuccoes of the Republican period. In addition, he addresses the question of the origin of this type of architectural decoration. Due to the absence of surviving physical evidence in Alexandria, Ling looks to the large amount of archaeological evidence from the greater Hellenistic world. ${ }^{9}$ Based on the evidence, he concludes that the stuccoes of the Republican period are a product of both Egyptian and Greek traditions. ${ }^{10}$

The increased interest in Roman stucco during the 1960s and 1970s led to the publication of Hetty Joyce's PhD dissertation titled, “The Decoration of Walls, Ceilings, and Floors in Italy in the Second and Third Centuries A.D." "11 Joyce's dissertation relies heavily on the scholarship of Ling as well as Wadsworth and considers all aspects of Roman architectural decoration. Inexplicably, after Joyce's publication in 1981, interest in Roman stucco declined, and there is an absence of scholarship on the subject until the publication of Claudine Allag and Nicole Blanc's conference paper titled, "Vouneuil et la tradition des stucs antiques" (2006). ${ }^{12}$ Allag and Blanc discuss late Imperial Roman stuccoes from the Italian peninsula as a means for contextualizing material from Roman Gaul; however, there is no attempt to interpret the stuccoes within the greater Mediterranean world.

Scholarship on late antique and early Byzantine stuccowork is not as extensive as on Roman material and tends to be limited to regions that contain the largest amount of extant material. The earliest scholarship (1920s) on this period considers the stuccoes at

\footnotetext{
${ }^{9}$ Ling (1972): 15.

${ }^{10}$ Ibid., 17.

${ }^{11}$ Hetty Joyce, The Decoration of Walls, Ceilings, and Floors in Italy in the Second and Third Centuries A.D. (Roma: Giorgio Bretschneider, 1981).

${ }^{12}$ Claudine Allag and Nicole Blanc, "Vouneuil et la tradition des stucs antiques" Stucs et décors de la fin de l'Antiquité au Moyen Âge (Ve-XIIe siècle): Actes du colloque international tenu à Poitiers du 16 au 19 Septembre 2004 (2006): 105-114.
} 
San Vitale in Ravenna. ${ }^{13}$ Joy Shapley undertook a detailed formal analysis of the stuccowork as well as attempted to contextualize the motifs within other sixth-century decorative material. Shapley also includes a discussion of the decorative trends of the region, which she defines as "Adriatic Art."14 According to Shapley, the eclecticism of this style, which she attributes to the prevalence of active trading centers in the upper Adriatic, can be compared to the eclectic nature of sixth-century Constantinopolitan styles. $^{15}$

Shapley's thorough investigation of this material is deeply indebted to the influential work of J. Strzygowski, whose publication of Orient oder Rom in 1901 led to a significant shift in the interpretation of late antique material culture. In this book, Strzygowski rejected the views of scholars who saw Italy, specifically Rome, as the source for all late antique artistic trends. ${ }^{16}$ The so-called Western School stood in sharp contrast to Strzygowski, who saw the eastern provinces as a source and origin for late antique artistic trends. ${ }^{17}$ His influence on subsequent scholars of late antique Italy is twofold: since the publication of his treatise, most scholars have adopted the approach of the Eastern School. However, this approach is limited to the study of mosaic and marble sculpture. Scholars working on these two media often return to the Western school of thought when discussing stuccowork. Frequently these scholars view late antique and

\footnotetext{
${ }^{13}$ J. Shapley, "The Stuccoes of San Vitale" Studien zur Kunst des Ostens. Josef Strzygowski zum sechzigsten Geburtstage con seinen Freunden un Schülern (1923): 19-32.

${ }^{14}$ Shapley (1923): 31.

${ }^{15}$ Ibid., 31.

${ }^{16}$ Josef Strzygowski, Orient oder Rom: Beiträge zur Geschichte der spätantiken und frühchristlichen Kunst. Leipzig: J.C. Hinrichs'sche Buchhandlung, 1901; and J. Strzygowski, "Orient or Rome: The Porphyry Groups at St. Mark's, Venice, as Test Case," translated by Iain Boyd White in Art in Translation 1:1, pp. 61-76 (2009). Originally published in German as "Orient oder Rom. Stichprobe: Die Porphyrguppen von S. Marco in Venedig," in C.F. Lehmann (ed.) Kilo: Beiträg zur alten Geschichte vol. 2, Leipzig: Dietrich'sche Verlagsbuchhandlung, (1902), pp. 105-124.

${ }^{17}$ Karen Britt, "Mosaics in the Early Byzantine Churches of Palestine: Innovation or Replication?" (PhD diss., Indiana University, 2003), 6.
} 
early Byzantine stuccowork as evidence for the decline of classical forms of art, based on the implied inferiority of stucco to more expensive materials like marble. However, scholars such as Laura Pasquini, whose primary focus is stuccowork, recognize its close connection to both classical antiquity and to the eastern half of the Mediterranean.

The work of Arthur Haselhoff will serve as a good example. In the 1930s, he published Pre-Romanesque Sculpture in Italy, a monograph that concentrated on the stone sculpture of the Italian peninsula during the late antique, early Byzantine, and Lombard periods. ${ }^{18}$ Haselhoff, in his chapter on the sculpture of Ravenna, concentrated on the marble sarcophagi found throughout the city. He examined them within the scope of other extant sculptural material, including the monumental stuccowork program of the Neonian (Orthodox) Baptistery. Haselhoff attributed what he viewed as a jumbled composition of the stucco assemblage to the "most astonishing lack of foresight and ability on the part of the artists." ${ }^{19}$ His interpretation, which lacks critical analysis, becomes problematic when he acknowledges the historical importance of stuccowork in the churches of Ravenna. ${ }^{20}$ He discusses the presence of stuccowork in textual sources but fails to place the baptistery's stucco program within an accurate historical framework, seeing it only as a later addition executed by mediocre artists. ${ }^{21}$

The influence of the Eastern School did, however, have a positive impact on the scholarship of stucco beyond the work of Shapley. During the 1960s, scholars began to

\footnotetext{
${ }^{18}$ Arthur Haselhoff, Pre-Romanesque Sculpture in Italy. (New York: Harcourt, Brace and Company: 1931).

${ }^{19}$ Ibid., 32.

${ }^{20}$ Ibid., 31.

${ }^{21}$ Ibid., 31.
} 
look outside of Ravenna to the stuccowork of Poreč and Constantinople. ${ }^{22}$ Then, in 1965, there was a renewal of interest in the monuments of Ravenna that began with Spiro Kostof's architectural survey of the Neonian (Orthodox) Baptistery. ${ }^{23}$ In his discussion of the decorative program, Kostof rejects the claims of the stuccowork program's later execution, as proposed by Haselhoff, instead, securely dating it to the same period as the mosaics of the dome above. ${ }^{24}$ Moreover, Kostof's formal analysis of this program acknowledges its original polychromed appearance and considers the use of the material in other Ravennate contexts. ${ }^{25}$ The most important aspect of his analysis, for this study, is the fact that Kostof connects the expressive quality of the figures and the drapery of their garments to earlier classical styles. ${ }^{26}$

Another interpretation of Ravennate stuccowork was written by M.T. Bracci Pinza in an article entitled, "Decorazioni in stucco degli edifici di culto paleocristiani di Ravenna" (1970). ${ }^{27}$ In her article, which continued the work of Shapley, Bracci Pinza places the large amount of stuccowork in San Vitale within a sixth-century historical framework. ${ }^{28}$ Also during the 1970 s, the study of Ravenna's late antique and early Byzantine architecture shifts from a focus on extant monuments to the excavation and interpretation of sites associated with textual sources. Archaeologists, using descriptions from Agnellus' ninth-century Liber pontificalis ecclesiae Ravennatis, began to excavate the churches of Santa Croce and Santa Agata. The excavation of the fifth-century church

\footnotetext{
${ }^{22}$ For Constantinople see E.J.W. Hawkins, "Plaster and Stucco Cornices at Haghia Sophia, Istanbul" Actes du XIIe Congrés International d'études byzantines (1964): 131-135; for Poreč see A. Šonje, "Gli stucchi della basilica eufrasiana di Parenzo" Felix Ravenna (1967): 51-68.

${ }^{23}$ S. Kostof, The Orthodox Baptistery of Ravenna. New Haven: Yale University Press, 1965.

${ }^{24}$ Kostof, 94-100.

${ }^{25}$ Ibid., 95.

${ }^{26}$ Ibid., 96.

${ }^{27}$ Maria Teresa Bracci Pinza, "Decorazioni in stucco degli edifici di culto paleocristiani di Ravenna" Felix Ravenna (1970): 151-167.

${ }^{28}$ Ibid., 151-156.
} 
of Santa Croce began in 1970 under the direction of the Soprintendenza ai monumenti led by Gino Pavan, Giuseppe Cortesi, and Monsignor Mario Mazzotti. ${ }^{29}$ These excavations revealed numerous fragments of stucco decoration that included both non-figural and figural motifs. ${ }^{30}$ While it is impossible to pinpoint the precise original location of these fragments, their discovery reveals that, indeed, stucco was commonly used in the decorative programs of ecclesiastical buildings as outlined in an article published by Gino Pavan in $1980 .^{31}$

The excavation of the presbytery at Santa Agata, under the direction of Eugenio Russo, took place between 1984 and 1985. These excavations, like those of Santa Croce, revealed numerous fragments of stucco decoration. ${ }^{32}$ These fragments date to the latefifth or early-sixth century, and consist of vegetal and geometric motifs. The original placement of these fragments is more secure due to their discovery in the area of the church's apse along with fragments of opus sectile, a commonly used material for apse decoration..$^{33}$

During the late 1980s and early 1990s, European scholars spearheaded scholarship on stucco. In particular, the work of Mab van Lohuizen-Mulder, whose article "Stuccoes in Ravenna, Poreč and Cividale of Coptic Manufacture" (1990) expanded upon his earlier publications in which he connected Coptic and Ravennate

\footnotetext{
${ }^{29}$ Laura Pasquini, La Decorazione a stucco in Italia fra tardo antico e alto medioevo (Ravenna: Longo Editore, 2002) 24.

${ }^{30}$ Giuseppe Cortesi, "La Chiesa di S. Croce di Ravenna alla luce degli ultimi scavi e ricerche" Corso di cultura sull'arte ravennate e bizantina (1978) 47-76.

${ }^{31}$ Gino Pavan, "Il problema della decorazione a stucco nelle basiliche ravennati alla luce degli ultimi ritrovamenti" Corso di cultura sull'arte ravennate e bizantina (1980) 137-165.

${ }^{32}$ Eugenio Russo, "Scavi e scoperte nella chiesa di S. Agata di Ravenna. Notizie Preliminari," in Actes du XIe Congrès international d'archéologie chrétienne: Lyon, Vienne, Grenoble, Genève et Aoste, (1989), pp. 2317-2341.

${ }^{33}$ Ibid., 2330-2335.
} 
decorative programs, has been influential. ${ }^{34}$ However, his conclusions have been refuted by Italian scholars such as Laura Pasquini, whose own contribution to Ravennate stucco scholarship is, perhaps, the most extensive. ${ }^{35}$

Pasquini's book, La decorazione a stucco in Italia fra Tardo Antico e Alto Medioevo (2002), provided a much needed resource on the topic of late antique and early Byzantine stucco. This book provides a comprehensive list of extant stucco from both the Italian and Istrian peninsulas and considers both the textual and archaeological evidence. Throughout the book, Pasquini connects the stuccowork of Italy and Istria to classical sources, Sasanian Persia, and the early Islamic Near East. Pasquini’s most successful comparisons occur in her discussion of the Lombard stuccoes at Cividale in relation to those of the Umayyad period. ${ }^{36}$

Another significant contribution is Emanuela Penni Iacco's book, La Basilica di S. Apollinare Nuovo di Ravenna attraverso I secoli (2004). This book provides a thorough architectural history of Theoderic's sixth-century church that includes a discussion of the non-extant stucco decoration described by Agnellus in the Liber pontificalis Ravennatis. ${ }^{37}$ Penni Iacco describes the architectural renovations that occurred during sixteenth century which raised the pavement in the nave by $1.25-1.5 \mathrm{~m}$

\footnotetext{
${ }^{34}$ For his earlier work see Mab van Lohuizen-Mulder. "Early Christian Lotus-panel capitals and other socalled Impost Capitals," in Bulletin Antieke Beschaving, 62 (1987), pp. 131-151; ibid, "The Cathedra of St. Mark in Venice," in Bulletin Antieke Beschaving, 63 (1988), pp. 165-179; and ibid, "The Two-zone Capitals," in Bulletin Antieke Beschaving, 64 (1989), pp. 172-183.

${ }^{35}$ Laura Pasquini, "Il battistero della cattedrale cattolica a Ravenna," in Venezia e Bisanzio : aspetti della cultura artistica bizantina da Ravenna a Venezia, V-XIV secolo, (2005), pp. 327-344.

${ }^{36}$ Pasquini (2002), 84-91.

${ }^{37}$ Emanuela Penni Iacco, La Basilica di S. Apollinare Nuovo di Ravenna attraverso I secoli (Bologna: Università di Bologna, 2004); and Agnellus of Ravenna, The Book of the Pontiffs of the Church of Ravenna. Translated by Deborah Mauskopf Deliyannis (Washington D.C.: The Catholic University of America Press, 2004): 200.
} 
and hypothetically destroyed the zone of stucco decoration that was placed above the nave arcade and below the level of fenestration. ${ }^{38}$

The most recent scholarship on late antique and early Byzantine stucco can be found in Stucs et décors de la fin de l'Antiquité au Moyen Âge (Ve-XIIe siècle), a volume of conference papers published in 2006. This volume contains papers on decorative stucco from France, Italy, and Istria. Christian Sapin’s paper "Vouneuil et les stucs de l'Antiquité tardive" contains an analysis of stucco fragments from a church dating between 450-550 CE, a date that would have impossible to reach without the use of modern archaeometric analysis. ${ }^{39}$ Gisella Cantino Wataghin's paper "Lo stucco nei sistemi decorative della tarda antica" provides a discussion of how stuccowork was viewed in antiquity alongside other forms of architectural decoration. ${ }^{40}$ The volume also includes Ivan Matejčić’s paper “Breve nota a novitá sulle decorazioni a stucco del periodo paleocristiano in Istria," which provides a summary of extant stuccowork on the Istrian peninsula. $^{41}$

The scholarship on late antique and early Byzantine stucco is limited due to the dearth of surviving evidence and, consequently, attempts to reconstruct non-extant decorative programs have been limited. A means of compensating for the absence of surviving stucco from these periods is to examine later Lombard and early Islamic scholarship on stucco. The scholarship of the Lombard period benefits from large

\footnotetext{
${ }^{38}$ Penni Iacco (2004), 34.

${ }^{39}$ Christian Sapin, "Vouneuil et les stucs de l'Antiquité tardive" Stucs et décors de la fin de l'Antiquité au Moyen Âge (Ve-XIIe siècle): Actes du colloque international tenu à Poitiers du 16 au 19 Septembre 2004 (2006): 59.

${ }^{40}$ Gisella Cantino Wataghin, "Lo stucco nei sistemi decorative della tarda antica" Stucs et décors de la fin de l'Antiquité au Moyen Âge (Ve-XIIe siècle): Actes du colloque international tenu à Poitiers du 16 au 19 Septembre 2004 (2006): 115-124.

${ }^{41}$ Ivan Matejčić, "Breve nota a novitá sulle decorazioni a stucco del periodo paleocristiano in Istria" Stucs et décors de la fin de l'Antiquité au Moyen Âge (Ve-XIIe siècle): Actes du colloque international tenu à Poitiers du 16 au 19 Septembre 2004 (2006): 125-132.
} 
amounts of extant material, most notably from the church of Santa Maria in Valle located in Cividale, and relies heavily on archaeological evidence. ${ }^{42}$ This evidence has been used by Italian scholars who connect the surviving figural stuccoes from Cividale to the figural stuccoes of the early Islamic Near East. ${ }^{43}$

Stucco from the Umayyad period (mid-seventh to mid-eighth century) has been the focus of scholarship by Islamic art historians for decades. Early studies of stuccoes from the desert palaces of the Umayyad period provided a basis for analyzing stuccowork in the medieval Islamic sphere, as well as the greater medieval world. ${ }^{44}$ The synoptic approach taken by scholars of the early Islamic Near East stands in sharp contrast to the selective one employed by scholars of the Western School, a division that again recalls J. Strzygowski's question, Orient oder Rom. ${ }^{45}$ Due to the abundant use of stucco, much of which is extant, when investigating architectural space, scholars of the early Islamic Near East found it difficult to ignore such a clearly important element of architectural decoration. The work of Finbarr Barry Flood exemplifies the inclusive approach adopted by Islamic art historians, and his discussions of Umayyad and Byzantine interaction in the Near East may provide a parallel for the classicizing tendencies of the monumental stuccoes of Lombard Italy. ${ }^{46}$

\footnotetext{
${ }^{42}$ Silvia Lusuardi Siena, ed., Cividale Longobarda: Materiali per una rilettura archaeologica (Milan: Università Cattolica, 2002); and Sergio Tavano, Il Tempietto Longobardo di Cividale (Longobarde, 1990).

${ }^{43}$ See Isabella Vaj, "Il tempietto di Cividale e gli stucchi omayyadi," in Cividale Longobarda: Materiali per una rilettura archaeologica (Milan: Università Cattolica, 2002): 175-204.

${ }^{44}$ R. W. Hamilton, "Carved Plaster in Umayyad Architecture" Iraq 15:1 (1953): 43-55; Ignacio Arce, "The Umayyad Carved Stucco from Amman Citadel Congregational Mosque" Lo Stucco Proceedings of the XVII International Conference "Scienza e Beni Culturali" (2001): 107-123; Finbarr Barry Flood, The Great Mosque of Damascus: Studies on the Makings of Umayyad Visual Culture. Leiden: Brill, 2001; and Garth Fowden, Qusayr 'Amra: Art and the Umayyad Elite in Late Antique Syria. Berkeley: University of California Press, 2004.

${ }^{45}$ Josef Strzygowski, Orient oder Rom: Beiträge zur Geschichte der spätantiken und frühchristlichen Kunst. Leipzig: J.C. Hinrichs'sche Buchhandlung, 1901.

${ }^{46}$ See Flood (2001).
} 
Scholarship on the stuccowork of the late antique and early Byzantine periods, as demonstrated, is limited. Fortunately, the scholarship on Roman, Near Eastern, and Islamic stucco is extensive and provides a model for the investigation of material from the fourth to sixth centuries in the Mediterranean world. 


\section{CHAPTER 2}

\section{METHODOLOGY}

Due to the nature of the material, it is necessary to adopt an interdisciplinary approach to answer the questions of influence and interpretation of late antique and early Byzantine stucco. In preparing for this thesis, I have synthesized literary and archaeological evidence in an effort to identify the intersections between the two types of data. These interconnections have allowed me to compile a dataset documenting the presence of stuccowork in the ecclesiastical monuments of Italy, Istria, and Constantinople. In this dataset I have documented the following characteristics of stucco: geographical location (e.g. Rome), contextual location (e.g. soffits of nave arcades), type (figural or non-figural), date, evidence of polychromy, and current condition (extant or non-extant). (Appendix 1)

As a result of this survey, I have found a combined total of twenty-one ecclesiastical monuments that contained evidence of stuccowork in the cities of Rome, Milan, Ravenna, Grado, Poreč, Pula, and Constantinople. Below is a summary of the information found in Appendix 1:

Fourteen out of twenty-one structures with original stuccowork are extant:

Rome:

Santa Maria Maggiore (c. 432-440 CE)

The Mausoleum of Quirinus of Sescia at San Sebastiano (c. fifth c. CE)

Santa Maria in Cosmedin (after 536 CE) 
Milan:

San Lorenzo (late-fourth to early-fifth c. CE)

Ravenna:

The so-called Mausoleum of Galla Placidia (after 425 CE)

The Neonian Baptistery (c. 450-473 CE)

The Archiepiscopal Chapel (c. 494-519 CE)

San Vitale (527-547 CE)

Grado:

Santa Maria del Grazie (c. 571-587 CE)

Poreč:

Basilica Eufrasiana (c. mid-sixth c. CE)

Eufrasiana Episcopal Palace Complex (c. mid-sixth c. CE)

Pula:

Santa Maria Assunta (fifth to sixth c. CE)

Santa Maria del Canneto (546-557 CE)

\section{Constantinople:}

Hagia Sophia (532-537 CE).

Three out of twenty-one structures are extant with archaeological evidence of stuccowork:

Ravenna:

Sant'Agata (late-fifth to early sixth c. CE)

Sant'Apollinare in Classe (mid-fifth to mid-eighth c. CE)

Arian Baptistery (late-fifth to early-sixth c. CE).

The Chapel of Sant'Aquilino at San Lorenzo (Milan; late-fourth to early-fifth c. CE) contains only photographic evidence of stucco. The church of Santa Croce (Ravenna; c. $430 \mathrm{CE}$ ) is non-extant; however there is an abundant amount of archaeological evidence. The two remaining structures do not contain extant or archaeological evidence; however, there is textual evidence from Agnellus' Liber pontificalis Ravennatis. These include the 
non-extant Ursiana Cathedral (Ravenna; c. 405-431 CE) and the extant church of Sant'Apollinare Nuovo (Ravenna; c. 504 or c. 557-570 CE). ${ }^{47}$

Each church surveyed contains examples of geometric and vegetal motifs in stucco that are found in various locations that include, most commonly, the soffits of arches and, in some cases, the vaulting of entrances. Where stucco occurs as a surface treatment for walls, it consistently acts as a visual separation between the marble revetment or opus sectile of the lower walls and the mosaic decoration above. Extant evidence of this employment of stuccowork is found in the Mausoleum of Galla Placidia, the Neonian Baptistery, the Archiepiscopal Chapel, Santa Maria del Grazie, the apse at the Basilica Eufrasiana, and the apse of Santa Maria del Canneto. Of the churches surveyed, four exhibit figural stuccowork motifs that include standing figures and, when extant, appear in sculpted architectural settings dressed in long flowing robes. These are found in the Mausoleum of Quirinus of Sescia at San Sebastiano, the Ursiana Cathedral, Santa Croce, and the Neonian Baptistery. Each of these figural stuccowork motifs, found exclusively on the Italian peninsula, date to the fifth century. By contrast, stuccowork that dates to the sixth century abandons the use figural imagery in favor of geometric and vegetal motifs.

Based upon the results of this data collection, I have identified trends in stuccowork during the late antique and early Byzantine periods. As mentioned, these trends include specific placement within monuments, decoration type, and connections with earlier patterns in Roman stuccowork. The identification of these trends will provide the basis for an interpretation of these stuccoes that contextualizes them among

\footnotetext{
${ }^{47}$ For the Ursiana Cathedral see Agnellus of Ravenna, The Book of the Pontiffs of the Church of Ravenna Translated by Deborah Mauskopf Deliyannis (Washington D.C.: The Catholic University of America Press, 2004): 119; for Sant'Apollinare Nuovo see ibid., 200.
} 
better known forms of architectural decoration in order to understand how they were viewed (literally and figuratively) during the late antique and early Byzantine periods. 


\section{CHAPTER 3}

\section{STUCCO AS MATERIAL: \\ THE PRODUCTION AND INSTALLATION OF STUCCOWORK DURING THE ROMAN PERIOD}

Stucco is a plastic material, made of plaster compounds, that was used to cover both interior and exterior surfaces in antiquity. Often, this stuccowork was unadorned and served simply as a wall covering to which paint or mosaic could be applied. However, decorative stuccowork, in the form of sculptural or architectural motifs, has had a long history in the architectural decoration of the ancient world. ${ }^{48}$ Antecedents for Roman stuccowork can be found in both Egyptian and Greek traditions. ${ }^{49}$ The difference between the stuccowork of these two civilizations lies in the chemical composition of the material which, in turn, influenced the variation in application. The earliest Egyptian stucco, a form of plaster that made use of gypsum which was based on calcium sulfate to create a quicker drying material, allowed for the use of molds and sculpting tools in order to create relief decoration. ${ }^{50}$ The durability and hardness of this type of stucco made it a close substitution for stone. ${ }^{51}$ The Minoans and Mycenaeans made use of a similar compound; however the tradition did not survive beyond the end of the Bronze Age. ${ }^{52}$ The earliest Greek stuccowork, on the other hand, was made of a slower drying lime-

\footnotetext{
${ }^{48}$ For eastern origins, see Neilson C. Debevoise, "The Origins of Decorative Stucco," American Journal of Archaeology 45:1 (1941), 45-61.

${ }^{49}$ For a full discussion of this see Wadsworth (1924), 9-11; and Ling (1972), 12-24.

${ }^{50}$ Ling (1972), 23.

${ }^{51}$ Ibid., 12-13.

${ }^{52}$ Ibid., 14.
} 
plaster compound, which was based on calcium oxide. ${ }^{53}$ The slower drying time of this material allowed for the application of fresco decoration and restricted sculptural decoration to any motif in low relief. It should be noted that while some scholars identify this type of early Greek wall decoration with the term "stucco," it can cause a great deal of confusion when discussing the sculptural stuccowork of later periods. ${ }^{54}$ For the sake of clarity, the term "stucco" in this thesis will be used to refer to a plaster compound (of gypsum or lime) that has been applied to ceilings, vaults, and walls with the use of molds and sculpting tools-i.e., sculptural stucco. As a result of Alexander's conquests during the fourth century BCE, these two earlier plaster-stucco traditions fused into what appears during the Roman period. ${ }^{55}$

While Roman artists utilized both gypsum and lime-plaster for their stucco decorations, after the Augustan period there was a preference for the latter. Often, gypsum was added to the lime-plaster compound to form a material that combined the durability of Egyptian stucco and the slow-setting quality of Greek examples. Roger Ling defines this type of stucco as "a hard slow-setting plaster based on lime and normally employed for architectural work." ${ }^{56}$ The production of lime-plaster stucco was complex and involved the manufacture of lime, a substance that does not occur naturally. It is useful to quote, at length, Roger Ling's description of this process:

Lime "has to be obtained by the calcination of one of the calcium carbonates (calcite and its massive varieties limestone, marble and chalk). When roasted, these give off carbon dioxide, being thus converted into quicklime (calcium oxide). The reaction can be expressed in the chemical formula:

\footnotetext{
${ }^{53}$ Ling (1972): 23.

${ }^{54}$ For a discussion of these issues see Claire Gapper, "What is 'Stucco'? English Interpretations of an Italian Term," Architectural History 42 (1999), 333-343; also Roger Ling, "Stuccowork," Roman Crafts (London: 1976), 209.

${ }^{55}$ Ling (1972), 17.

${ }^{56}$ Ling (1976), 209.
} 


$$
\mathrm{CaCO}_{3}+\text { heat } \rightarrow \mathrm{CaO}+\mathrm{CO}_{2}
$$

The new material has lost nothing in volume, but weighs barely half as much as the original calcium carbonate, and may easily be broken up. If it were now treated with just sufficient water, it would give off considerable heat before crumbling to a white powder (slaked lime or hydrate of lime).

$$
\mathrm{CaO}+\mathrm{H}_{2} \mathrm{O} \rightarrow \mathrm{Ca}(\mathrm{OH})_{2}+\text { heat }
$$

But treatment with more water produces the thick suspension of this powder in water which is mixed with some form of grit to create the mortar and plaster used by builders. In drying it takes back carbon dioxide from the air and reverts to what it was at the beginning of the cycle: calcium carbonate.

$$
\mathrm{Ca}(\mathrm{OH})_{2}+\mathrm{CO}_{2} \rightarrow \mathrm{CaCO}_{3}+\mathrm{H}_{2} \mathrm{O} \text {, } 57
$$

The most labor intensive of these processes was the slaking of lime. This required the use of the purest calcite sources in addition to creating temperatures hot enough to begin the calcination process. The earliest textual evidence for the slaking of lime and subsequent production of lime-plaster stucco comes from the first century BCE architect, Vitruvius. In book VII of De Architectura he describes the importance of consistency in the preparation of lime and adds that once lime has been properly slaked it should be broken into pieces with a metal hoe. ${ }^{58}$ He states, “...when the lime is rich and properly slaked, it will stick to the tool like glue, proving that it is completely tempered." ${ }^{\text {59 }}$ (fig. 1) Once the lime has been properly slaked, it can be added to a variety of plaster mixtures that vary in accordance to their use. According to ancient sources, milk and saffron could be added to retard drying times and it was recommended that crushed tile or brick be added for use in humid areas. ${ }^{60}$ Perhaps the most common additive to lime-plaster was marble dust.

\footnotetext{
${ }^{57}$ Ling (1976), 210.

${ }^{58}$ Vitruvius. The Ten Books on Architecture trans. Morris Hicky Morgan (New York: Dover Publications, Inc., 1960), 204-210.

${ }^{59}$ Ibid., 205.

${ }^{60}$ Ling (1976), 212.
} 
The addition of this substance altered the appearance of the final product to imitate the luminous qualities of real marble. According to Vitruvius, the selection of marble was essential to the outcome of the final product. He writes,

"Marble is not produced everywhere of the same kind. In some places the lumps are found to contain transparent grains like salt, and this kind when crushed and ground is extremely serviceable in stuccowork. In places where this is not found, the broken bits of marble or 'chips,' as they are called, which marble-workers throw down as they work, may be crushed and ground and used in stucco after being sifted."

Yet, these stuccoes should not be viewed as mere imitations of marble but an improvement upon another popular material used for architectural decoration:

terracotta. ${ }^{61}$ The similarities between terracotta and stucco stem from their plastic natures and their adaptability to a variety of surfaces. However, unlike terracotta, which has to be molded and fired in a kiln prior to installation, stucco is unique in its ability to be molded, sculpted, and allowed to dry to a comparable hardness in situ. The adaptability of stucco accounted for its popularity, especially during the post-Augustan period, as a material for architectural decoration throughout the Roman world.

The employment of stucco decoration was just as dependent on environmental factors as its production. According to Vitruvius, dry rooms that were to contain an abundance of artificial light should be decorated with flat stucco atop a sand-mortar rendering coat to serve as a smooth base for wall paintings to allow for easier cleaning. ${ }^{62}$ Vitruvius explains that when this type of decoration is properly executed it "does not get rough as time goes on, nor lose its colors when it is wiped off." ${ }^{\text {63 }}$ In dry rooms that are

\footnotetext{
${ }^{61}$ Ling (1972), 21.

62 Vitruvius (1960), 206-207.

${ }^{63}$ Ibid., 207.
} 
free from such environmental concerns, relief stuccowork should be applied. ${ }^{64}$ Vitruvius also explains how to properly install stucco in damp interior spaces. He suggests that burnt brick should be added to the rendering coat, instead of sand, in order to compensate for the increased levels of moisture on the walls. Lime-plaster is then applied to this rendering coat in layers until a smooth finish is achieved. In more humid rooms with an abundance of artificial light, flat stuccowork and wall paintings should, again, be applied to walls and ceilings. Vitruvius explains that in winter dining rooms, specifically,

"neither paintings on grand subjects nor delicacy of decoration in the cornice work of the vaultings is a serviceable kind of design, because they are spoiled by the smoke from the fire and the constant soot from the lamps. In these rooms there should be panels above the dadoes, worked in black, and polished, with yellow ochre or vermilion blocks interposed between them." ${ }^{, 65}$

The conservative nature of this painted decoration, albeit for a specific space, is contrasted with the lavish quality of sculptural stucco. This type of three-dimensional stucco, according to Vitruvius, was appropriate "in summer apartments and in exedrae where there is no smoke nor soot to hurt them., ${ }^{, 66}$ Therefore, stucco decoration became a popular medium for the adornment of niches as well as the vaulting of subterranean architectural spaces.

The installation of stucco was an elaborate process that involved the application of successive layers of plaster upon a wooden framework. Furring strips made of cypress and woven reeds were affixed to walls and ceilings to create the curves necessary for vaulted surfaces. ${ }^{67}$ Depending on the environmental conditions of the room, either lime

\footnotetext{
${ }^{64}$ Vitruvius (1960): 207.

${ }^{65}$ Ibid., 209-210.

${ }^{66}$ Ibid., 206.

${ }^{67}$ Ibid., 205.
} 
or sand-plaster was applied to the framework in layers until a smooth coat was achieved.

Vitruvius explains the preparation of a wall for fresco decoration:

“...apply a very rough rendering coat to the walls, and afterwards, when the rendering coat gets pretty dry, spread upon it the layers of sand mortar, exactly adjusted in length to rule and line, in height to the plummet, and at the angles to the square. The stucco will thus present a faultless appearance for paintings. When it gets pretty dry, spread on a second coat and then a third. The better the foundation of sand mortar that is laid on, the stronger and more durable its solidity will be the stucco.

When that has been applied and well rubbed down, spread on a finer coat. The walls, being thus rendered solid by three coats of sand mortar and as many of marble, will not possibly be liable to cracks or to any other defect." 68

Ancient sources are a valuable tool for understanding how smooth stucco was applied as a base for fresco decoration. However, there is little written about architectural and sculptural stucco. Perhaps this is due to the fact that Vitruvius was writing during the Augustan period, which provided few examples of these threedimensional types of stucco. Of the examples that do exist, such as late-Republican and early-Imperial stucco ceiling-coffers, Vitruvius writes, "we must also beware of the ancients' scheme for vaultings; for in their moldings the soffits overhang very heavily, and are dangerous.." ${ }^{\circ 9}$ Therefore, it is during the post-Augustan period, after the processes had been perfected, that sculptural stucco becomes a popular form of architectural decoration.

We can surmise that the application of sculptural stucco followed the same steps outlined by Vitruvius, with the addition of three-dimensional architectural members and figural work on top of the rendering coat. The tools used by stuccoists were made of wood, which explains their absence in the archaeological record. There are, however,

\footnotetext{
${ }^{68}$ Vitruvius (1960) 206-207.

${ }^{69}$ Ibid., 206.
} 
stone examples from excavations at Aegina that date to the fifth or sixth century BCE. ${ }^{70}$ These stone tools, due to their weight, were used to smooth floors and are quite similar to modern floats. In addition to floats of different shapes and sizes, stuccoists also relied on trowels of varying shapes and sizes. ${ }^{71}$ (fig. 2) Depending on the composition, artists would divide the surface into highly organized panels, that, during the Republican period, contained repeating geometric low relief panels.

In addition, Republican artists installed imitation marble veneers that covered columns made of either tufa, travertine, or brick. As stated, the addition of marble dust allowed dried and polished stucco to take on the appearance of finely carved marble. More importantly, the application of these stucco veneers created a seal, which protected the tufa and travertine construction from the damages of humidity and water vapor. ${ }^{72}$ One of the earliest examples comes from the Temple of Portunus. (fig. 3) This tradition continued during the Roman Empire, as evidenced by the numerous examples found at Herculaneum (fig. 4), and well into the late antique period. (fig. 5)

It is during the Imperial period that trends in stuccowork shift from protective or structural in function to the exploitation of the material for decorative purposes. This begins to occur with the decorative stucco capitals from the high Imperial period, examples of which can be found at Herculaneum. (fig. 6) The stuccowork of this period is characterized by its compositional organization, which dictated the function of a particular space, and the artist's skillful use of modeling to create naturalistic vegetal and

\footnotetext{
${ }^{70}$ Ling (1976), 214.

${ }^{71}$ Ibid., 214.

${ }^{72}$ For a full discussion of this see, M.D. Jackson et al., "The Judicious Selection and Preservation of Tuff and Travertine Building Stone in Ancient Rome," Archaeometry 47:3 (2005): 485-510.
} 
figural motifs. ${ }^{73}$ While the use of molds was common in the application of repeating geometric motifs, figural reliefs relied on the combined skills of painting and sculpting. These three-dimensional paintings began with sinopias, or underdrawings, that could be sketched or scratched onto the prepared surface. ${ }^{74}$ For figural scenes without landscape or architectural settings, as was common, a mass of lime-plaster was applied to the prepared surface. ${ }^{75}$ Then, artists modeled figural motifs in situ with long and relatively lightweight bronze tools. (fig. 7) These double-ended tools contained a curved rectangular end that was useful for removing larger portions of plaster while the pointed end was essential for adding fine details. It should be noted that these tools were found in sculpture workshops and were most likely used for the production of clay models. ${ }^{76}$

Since workshops specializing in stucco production and installation are impossible to identify and considering the close connection between stuccowork and terracotta manufacture we can surmise that similar tools would have been used in both processes.

The best preserved examples of these post-Augustan stucco reliefs were removed during the nineteenth and twentieth centuries from their original contexts and placed in museums throughout Europe and North America. ${ }^{77}$ Fortunately, many examples, such as the vaulted tombs of Roman necropoli, have retained their original context. Emily L. Wadsworth catalogued these extant stuccoes in her comprehensive survey, "Stucco

\footnotetext{
${ }^{73}$ This theory has been applied in the investigation and interpretation of Roman floor mosaics, most recently, by Ellen Swift. For a full discussion see Ellen Swift, Style and Function in Roman Decoration: Living with Objects and Interiors (Farnham, Ashgate, 2009): 27-104, esp. 70-74.

${ }^{74}$ Ling (1976), 217.

${ }^{75}$ Ibid., 217.

${ }^{76}$ Ibid., 220.

${ }^{77}$ M.B.W., (1923): 15-16; D.E. Strong, "A Group of Roman Stucco Reliefs,” The British Museum Quarterly 21:4 (1959): 98-100; Roger Ling, "Some Roman Stucco Reliefs from Pozzuoli now in The British Museum," Papers of the British School at Rome 34 (1966): 24-33 and pl. VII-XI; and Roger Ling, "Roman Paintings and Stucco Reliefs in the Victoria and Albert Museum," Papers of the British School at Rome 49 (1981): 46-58 and pl.V-XIII.
} 
Reliefs of the First and Second Centuries still Extant in Rome."78 Included in her survey was a description of the so-called "Underground Basilica," a monument also studied by Eugénie Strong and Norah Jolliffe. ${ }^{79}$

This hypogeum, or subterranean structure, has been dated, based upon the composition of concrete used in its construction, to the mid-first century CE. This date has been supported by the dating of the mosaic and stucco decoration to the same period. According to various scholars, this structure was used for traditional Roman religious rituals for groups such as the Neo-Pythagorean sect. ${ }^{80}$ The most unusual feature of this hypogeum is the architectural plan, which unlike typical Roman religious spaces, is not a typical temple-plan, but a basilica. (fig. 8) This is highly unusual, especially at this early date. It is not until the Constantinian period that we find examples of civic building-types being used for religious worship. It should be acknowledged, however, that this so-called "underground basilica" was not a free-standing structure, but one that was excavated into the ground similar to nearby necropoleis. ${ }^{81}$ Yet, the decoration of the hypogeum is not unusual for the period. The stucco decoration, which covers the barrel vaults of the nave and two side aisles, contains various mythological scenes alongside depictions of winged victories. $^{82}$ (fig. 9) The composition of the barrel vaults recall earlier trends in stucco decoration, specifically the so-called "coffer-style" identified by Roger Ling. ${ }^{83}$

\footnotetext{
${ }^{78}$ Wadsworth (1924): 9-102

${ }^{79}$ Eugénie Strong and Norah Jolliffe, "The Stuccoes of the Underground Basilica near the Porta Maggiore," Journal of Hellenic Studies 44 (1924): 65-111.

${ }^{80}$ For a discussion of the hypotheses of M. Cumont and F. Fornari and Luigi, see Strong and Jolliffe (1924): 68.

${ }^{81}$ Ibid., 68-69.

${ }^{82}$ For a detailed discussion of the stucco decoration see, Wadsworth (1924): 79-87; and Strong and Jolliffe (1924): 71-111.

${ }^{83}$ Roger Ling, "Stucco Decorations at Baia," Papers of the British School at Rome 45 (1977): 31-32; and Ling (1972): 11-58.
} 
The conservative nature of the composition is juxtaposed with the spontaneity of the stuccoes themselves. These stuccoes, similar to examples housed in museums, exude a lively quality that is less like sculpture and more like the expressive qualities of painting. These stuccoes represent a different form of architectural decoration, further removed from stone sculpture than previously acknowledged. As stated, the plastic quality of these stuccoes allows for a new kind of artistic expression, one that recalls the fluidity found in the brushstrokes of wall-painting. Unlike the rigid tool marks found in marble sculpture, evidence of the artistic hand can be seen in the delicate impressions left by the stuccoist's tools and, most remarkably, their hands. The presence of finger and handprints in the stuccoes of ancient Rome recall similar qualities of ceramic production. Yet with a significant difference: these finger and handprints have moved from being visible on everyday objects, to the walls, ceilings, and vaults of architecture. 


\section{CHAPTER 4}

\section{SHIFTING WESTERN CAPITALS: ROME, MILAN, AND RAVENNA}

Trends in architecture and architectural decoration are inevitably related to their historical context and, therefore, it is essential to firmly situate their evolution within the social, political, and religious atmosphere of the late antique Mediterranean. Prior to Diocletian's reign, the city of Rome remained the political and cultural center of the Empire until a catastrophic fire in the ceremonial center of the city as well as continued reports of civilian and military unrest began to change the city's status. ${ }^{84}$ Then, Diocletian's adept political maneuvers of the late-third century caused a visible shift in political power away from Rome and toward the newly established capitals of the Tetrarchy at Trier, Milan, Sirmium, and Nicomedia. ${ }^{85}$ After the collapse of the Tetrarchy and the re-unification of the Roman Empire as a result of the military victories of Constantine I, a new imperial capital was established at Byzantium. This "New Rome," named after its founder, would become the administrative center of the Roman Empire for the remainder of late antiquity; however, Rome remained an influential bastion of classical antiquity even as it became integrated with the newly established Christian authority. The nature of Rome's authority in both traditional religious and Christian contexts would shape the policies of fourth century Rome and its provinces, and

\footnotetext{
${ }^{84}$ John Curran, Pagan City and Christian Capital: Rome in the Fourth Century (Oxford: Clarendon Press, 2000): 43.

${ }_{85}$ Andrew Gillett, "Rome, Ravenna and the Last Western Emperors," Papers of the British School at Rome vol. 69 (2001): 133.
} 
continued to do so for the remainder of the medieval period. ${ }^{86}$ Constantine and his successors were acutely aware of Rome's historical authority even after the rise of Christianity and, during the political and religious tumult of the fifth century, the emperors, bishops, and religious leaders of the Mediterranean looked to the caput mundi for support. ${ }^{87}$

\section{Constantine and Rome in the Fourth Century}

The rise in monumental Christian architecture in the city of Rome appeared almost immediately after Constantine's victory over his fellow Tetrarch, Maxentius, at the Battle of the Milvian Bridge on October 28, 312. The first of Constantine's monumental churches, which borrowed heavily from traditional Roman architectural forms, was the Basilica Constantiniana (Lateran). This church was built on a plot of imperial patrimony over the site of Maxentius' horse guards. John Curran argues that the construction of the Lateran, a distinctly Christian monument, over a site closely associated with Maxentius illustrated Constantine's desire to eradicate the city of "the specter of his rival." ${ }^{88}$ Curran suggests that the Lateran, unlike the funerary basilicas of S.S. Peter and Paul, was an example of an ex-voto church, one that was built in celebration of his victory over Maxentius. ${ }^{89}$ The dedication of the church, according to Curran, dates to November 312, approximately fourteen days after Constantine's victory

\footnotetext{
${ }^{86}$ Averil Cameron, "Remaking the Past," Interpreting Late Antiquity: Essays on the Postclassical World (Cambridge: The Belknap Press of Harvard University Press, 2001): 1-20.

${ }^{87}$ Richard Krautheimer, Three Christian Capitals: Topography and Politics (Berkeley: University of California Press, 1983): 93.

${ }^{88}$ Curran (2000): 96.

${ }^{89}$ Ibid., 95.
} 
over Maxentius at the Milvian Bridge. ${ }^{90}$ This is similar to the ex-voto construction of the Arch of Constantine, a monument that was erected by the Roman senate three years later.

The architectural forms of these early fourth-century monuments are noteworthy for their adoption of traditional Roman architectural forms. Constantine's deliberate appropriation of the Roman civic basilica for Christian sacred spaces emphasized the emperor's wish to impart imperial legitimacy to the emerging religion. Moreover, the issue of the so-called Edict of Milan in $313 \mathrm{CE}$ forced traditional Roman cults to share the urban topography of Rome with the newly sanctioned monotheistic religion. The Edict of Milan explicitly stated that followers of traditional Roman religions and Christianity were to "have been granted a similarly open and free permission to follow their own religio and worship as befits the peacefulness" of the time, which followed a period of state-sponsored Christian persecution. ${ }^{91}$ The Edict of Milan illustrated Constantine's understanding of the complex relationship between the followers of traditional Roman religions and Christianity; therefore, he proceeded to construct monumental Christian architecture on the outskirts of Rome. Moreover, in the tradition of "good emperors," Constantine built traditional Roman monuments in the Forum Romanum. Again, these traditional buildings were built with the intention of eradicating the memory of Maxentius and of stressing the legitimacy of Constantine's reign. This can be seen in his renovation of the Basilica Nova, begun by Maxentius, in which Constantine installed a colossal statue of himself. His respect for the traditions of the

\footnotetext{
${ }^{90}$ Curran bases this hypothesis upon the work of Krautheimer who identified two foundation dates associated with the Lateran. Krautheimer suggested that November 312 should correspond to the dedication, literally the dedicatio, of land for imperial use, while November 318 should correspond to the consecration of the church upon its completion. For Curran's summary, see Curran (2000): 94-95. For Krautheimer's hypothesis, see Richard Krautheimer, Corpus Basilicarum Christianarum Romae vol. V, (Città del Vaticano: Pontificio Instituto di Archeologia Cristiana, 1937-): 90.

${ }^{91}$ Curran (2000): 170-171.
} 
urban topography was restricted to Rome and the Italian peninsula, due to the presence of the Senate, which, by this time, was a nominal entity made up of the elite. ${ }^{92}$ When Constantine moved his capital to Byzantium, he did not feel constrained by the established classical heritage that pervaded all aspects of the urban landscape. In Constantinople, he was free to place monumental church architecture in the heart of the city without the fear of offending the stalwarts of Roman traditional religion.

The ability of Constantine to straddle both sides of the early fourth-century religious divide is illustrated by the adaptability of his building programs. In Rome, a respect for the classical past and its use in his own bid for legitimacy led him to place his Christian monuments, which represented the future, away from the historical city center. Yet, outside of Rome, site appropriation was aligned with pre-existing sites of Christian worship, such as martyr shrines or tombs. The notion that the emperors of the earlyfourth century ceded their architectural aspirations to the influence of the classical past can be explained by the way contemporaries viewed history. Averil Cameron writes, "The past was very real to the men and women of late antiquity: as they saw it, it had not so much to be remade as to be reasserted." ${ }^{, 93}$ This reassertion was present, not just in Rome, but in many cities in Italy.

The more civil relationship between followers of traditional Roman religions and Christians in the early fourth century underwent a drastic change during the brief, but

\footnotetext{
${ }^{92}$ For complete discussions of this see Allen Doig, Liturgy and Architecture: From the Early Church to the Middle Ages (Aldershot: Ashgate Publishing Company, 2009): 21-52; Neil Christie, From Constantine to Charlemagne: An Archaeology of Italy AD 300-800 (Aldershot: Ashgate Publishing Company, 2006): 80107; Johannes Roldanus, The Church in the Age of Constantine: The Theological Challenges (London: Routledge, 2006): 11-19; Géza Alföldy, "Difficillima Tempora: Urban Life, Inscriptions, and Mentality in Late Antique Rome," Urban Centers and Rural Contexts in Late Antiquity ed. Thomas S. Burns and John W. Eadie (East Lansing: Michigan State University Press, 2001): 3-24; A.D. Lee, Pagans and Christians in Late Antiquity: A Sourcebook (London: Routledge, 2000): 80-110; and Curran (2000): 70-115;

${ }^{93}$ Cameron (2001): 2.
} 
tumultuous, reign of Julian the Apostate. This Christian-born emperor, who renounced his faith, began to support the destruction and dissolution of Christian edifices and reinstatement of traditional Roman temples. ${ }^{94}$ The most visible example of this could be seen in the emperor's attempt to reconstruct the Jewish Temple in Jerusalem. ${ }^{95}$ This reconstruction was sanctioned, not for any particular feelings of good will toward the Jewish population of Jerusalem, but as a way to aggravate Palestinian Christians. Contemporary with the events in Jerusalem was the reinstallation of the Altar of Victory in Rome, a monument first erected by Augustus to commemorate the Battle of Actium in 31 BCE. ${ }^{96}$ This monument, removed by Julian's predecessor, the emperor Constantius II in $357 \mathrm{CE}$ at the request of Christian Senators, served as a place for traditional Roman ritual sacrifice prior to senatorial gatherings. ${ }^{97}$ In the wake of Julian's reign, Christians rallied around clergymen who reversed the emperor's anti-Christian policies, which included the removal of the Altar of Victory. ${ }^{98}$ The rise in status of the clergy during the late-fourth century began to rival that of emperors who, during the reign of Gratian, dropped the title of pontifex maximus, which paved the way for the increased authority of the Church. ${ }^{99}$ The renewed status of Christianity during the post-Julian period also led to an increase in the religion's architectural presence in the ancient city. It was during the second half of the fourth century that Popes sanctioned the construction of basilica-style churches within Rome's city walls. These churches, often supplanted their domus

\footnotetext{
${ }^{94}$ Lee (2000): 94.

${ }^{95}$ Hagith Sivan, Palestine in Late Antiquity (Oxford: Oxford University Press, 2008): 204-210.

${ }^{96}$ Lee (2000): 111.

${ }^{97}$ Christie (2006): 81-82.

${ }^{98}$ The final removal of the Altar of Victory occurred in 382 during the reign of Gratian with the influence of Pope Damasus. See Lee (2000): 111.

${ }^{99}$ Lee (2000): 111; also see Gisella Cantino Wataghin, "Architecture and Power: Churches in Northern Italy from the 4th to the 6th c." Social and Political Life in Late Antiquity ed. William Bowden et al (Leiden: Brill, 2006): 287-309.
} 
ecclesiae predecessors, forever altered the religious topography of Rome, and transformed the city into a wholly Christian capital by the dawn of the fifth century. ${ }^{100}$

\section{Ambrose and Milan in the Fourth Century}

Even with the rise in status of the clergy, the Church continued to remain fiscally connected to the Roman aristocracy, as is exemplified by the political and religious atmosphere of late-fourth century Milan. This northern Italian city became an imperial capital during the Tetrarchy and was the residence of Maximian from 293 to 305. ${ }^{101}$ The city was designed according to a traditional Roman plan that centered on a forum surrounded by various entertainment complexes. The topographical similarities between Milan and Rome began to change in the post-Constantinian period with the construction of monumental church architecture in the center of the city, unlike the peripheral arrangement found in Rome. As Krautheimer notes, "The map of Milan in the second half of the fourth century mirrors a conflict of political and religious ideas, just as that of Rome did fifty years before under Constantine, with the difference that in Milan the contenders were Christian factions and the bishop versus the emperor rather than an emperor turning with Christian sympathies versus a conservative senate." ${ }^{\prime 102}$ As a result, Milan became a center of debate between Orthodoxy and Arianism.

The theological underpinnings of these debates originated with an Alexandrian presbyter named Arius who preached that Christ had only one nature, and that nature was solely human. ${ }^{103}$ These views, in direct conflict with the Orthodox view that Christ had

\footnotetext{
${ }^{100}$ Krautheimer (1983): 94.

${ }^{101}$ Ibid., 69.

102 Ibid., 69.

${ }^{103}$ William Harmless, s.j., Desert Christians (Oxford: Oxford University Press, 2004): 25-27.
} 
two natures (human and divine), became widely popular in the western half of the empire, especially among the Constantinian emperors. These emperors, including Constantius II who resided in Milan for two years of his reign, secured the appointment of bishops sympathetic to the Arian cause. The episcopacy of Auxentius, an Arian, was fraught with political maneuvering on the part of emperors who subscribed to the views of Arian theology and Orthodox Christians who sided with the opposition led by Athanasius of Alexandria. Constantius II, who resided in Milan from 352 to 355, exerted his imperial authority with the appointment of Auxentius after the Council of Milan in 355, which ratified the condemnation of Athanasius' Orthodox views. ${ }^{104}$ As a result, the city of Milan became a center for Arian theology, which led to the construction of Arian churches in the center of the city. ${ }^{105}$ However, after the deaths of the pro-Arian leadership of Constantius II and Auxentius by 374, the religious tension between Arian and Orthodox Christians rose to a new level.

Ambrose, the successor of Auxentius who was appointed in December 374, sought to unite the two Christian factions of Milan. The distinctly imperial style of leadership employed by Ambrose is a direct result of his own background. Ambrose was born in 339 during his father's tenure as praetorian prefect at the court of Constantine II in Trier. ${ }^{106}$ After his father's premature death, Ambrose's family moved to Rome where he received a classical Roman education. ${ }^{107}$ The impact that the city of Rome had on the young Ambrose cannot be discounted and, as he honed his Romanitas, he also bore

\footnotetext{
${ }^{104}$ Neil McLynn, Ambrose of Milan: Church and Court in a Christian Capital (Berkeley: University of California Press, 1994): 14.

${ }^{105}$ For a discussion of these Arian churches see Christie (2006): 108-109; and Doig (2009): 58-61.

${ }^{106}$ McLynn (1994): 32.

${ }^{107}$ Ibid., 32.
} 
witness to the political and religious tensions between emperors and church leaders. ${ }^{108}$ Ambrose followed in the shadow of his father's career and became "an advocate in the praetorian prefect's court at Sirmium."109 This choice of career secured Ambrose's status on the margins of Roman aristocracy, which at the time was still closely associated with traditional Roman values. ${ }^{110}$

At the same time, Ambrose's family was deeply connected to Christian martyr worship, an increasingly popular movement. The burial of Ambrose's mother next to the third-century virgin-martyr, Soteris, was claimed by his sister, Marcellina, to be evidence of the family's Christian ancestry. ${ }^{111}$ The familial connection to an early Christian martyr increased the religious authority of Ambrose and led to his promotion by Petronius Probus, the wealthy praetorian prefect of Italy, in the late 360 's. ${ }^{112}$ During this period, the popularity of Pope Damasus led to an increased devotion to Orthodox Christianity among the Christians of Rome. Conversely, in Milan, the same period witnessed the height of Auxentius' Arian majority. The polarity between the Orthodox adherents in Rome and the Arian followers in Milan can be explained by the relatively neutral response of Valentinian I. Pope Damasus' predecessor, Liberius, discussed Valentinian I's stance on religious matters and stated, "His reign was distinguished by toleration in that it remained neutral in religious differences neither troubling anyone on the ground nor ordering him to reverence this or that. He did not bend the necks of his subjects to his own belief by threatening edicts but left matters undisturbed as he found them."113

\footnotetext{
${ }^{108}$ He was sixteen at the time of the Council of Milan where the divide between Arian and Orthodox Christians widened.

${ }^{109}$ McLynn (1994): 37.

${ }^{110}$ Ibid., 37.

${ }^{111}$ Ibid., 34-35.

112 Ibid., 38-39.

${ }^{113}$ From Liberius, Oratio 30, quoted by Curran (2000): 198.
} 
This hands-off approach allowed religious factions to develop, unchecked, and led to the appointment of the politically-savvy Ambrose in 374.

Ambrose was the successor of the Arian bishop, Auxentius, who had a loyal following among the Christian citizens of Milan. Well-versed in the politics of the Roman aristocracy, Ambrose ceded his reservations about his appointment as bishop to the will of Valentinian I, who resided in the imperial palace at Milan. ${ }^{114}$ However, the tension between Ambrose and the Valentinian dynasty led the bishop to look to the eastern provinces for a political and religious ally. The devoutly Orthodox emperor of the East, Theodosius I, enjoyed a close relationship with the Milanese bishop. After an unnecessary and disastrous military campaign in 390 at Thessaloniki, Theodosius travelled to Milan in order to join the ranks of penitents. ${ }^{115}$ McLynn describes this as a "solution provided by Ambrose, who turned the catastrophe into a public relations triumph for the emperor." ${ }^{\text {"16 }}$ The subordination of the Constantinopolitan Augustus to the Bishop of Milan before an audience of Milanese Christians illustrated the religious and political authority that Ambrose had sought to cultivate since his consecration and, therefore, was a political relations victory for the bishop, as well. ${ }^{117}$

This new level of authority allowed Ambrose the freedom to lead the Milanese church, as well as to engage more closely in political affairs. It is not surprising, then, that he chose to model his episcopacy upon the imperial reign of Constantine. This notion became visible in the built environment; during his tenure, Ambrose solicited the construction and renovation of a series of churches as well as the creation of a sprawling

\footnotetext{
${ }^{114}$ Ambrose, reluctant to become bishop, was highly recommended by Valentinian's close friend, and Ambrose's benefactor, Petronius Probus. See McLynn (1994): 49.

${ }^{115}$ McLynn (1994): 323.

${ }^{116}$ Ibid., 323.

${ }^{117}$ Ibid., 323.
} 
Episcopium, the Episcopal residential complex, which took on the role of a traditional Roman forum. ${ }^{118}$ The building program of Ambrose mirrored the Constantinian foundations of Rome as well as the imperial complex of Constantinople. The construction of a triumphal arch, situated on the road that connected Milan to Rome, which opened onto a porticoed causeway, recalled imperial routes in both Rome and Constantinople. (fig. 10) Additionally, Ambrose's construction of the Church of the Apostles was known to be a copy of the Constantinian Apostoleion in Constantinople. ${ }^{119}$ The success of Ambrose's policies should, again, be attributed to his carefully cultivated public persona as a distinctly imperial-like bishop, modeled on the life of Constantine. The authority associated with Constantine was not lost on the leaders, religious and political, of the late-fourth century. Again, there was a desire among all leaders of late antiquity to reassert and stress their personal connections to the past, which appeared physically in the implementation of classicizing motifs in the art and architecture of the period. ${ }^{120}$

\section{Ravenna in the Fifth Century}

After the death of Theodosius I in 395, the Empire was split into eastern and western halves between Theodosius I's two sons. Arcadius took up residence in Constantinople, while his brother, Honorius, moved to Italy. There had been an imperial residence in Milan since the days of the Tetrarchy; however, in 402 Honorius decided to

\footnotetext{
${ }^{118}$ Wataghin (2006): 294-295; and Christie (2006): 108.

${ }^{119}$ Christie (2006): 109; and Doig (2009): 58.

${ }^{120}$ Several scholars have addressed this subject. See Ernst Kitzinger, "The Hellenistic Heritage in Byzantine Art," Dumbarton Oaks Papers 17 (1963): 95-115; George M.A. Hanfmann, "The Continuity of Classical Art: Culture, Myth, and Faith," Age of Spirituality: A Symposium ed. Kurt Weitzmann (New York: Metropolitan Museum of Art, 1980): 75-99; and Bente Kiilerich, Late fourth century classicism in the plastic arts : studies in the so-called Theodosian renaissance (Odense: Odense University Press, 1993).
} 
move his capital for strategic and, primarily, defensive reasons. The ongoing invasions of Germanic speaking groups from the north, themselves driven out by the Hunnic invasions, into Italian territory forced Honorius to look for a safer capital. Honorius chose the Roman port city of Ravenna, which was conveniently located on the shores of the Adriatic and, therefore, had access to the ports of North Africa and the Eastern Mediterranean. ${ }^{121}$ Additionally, the city was protected by a variety of environmental factors, which included a marshy topography to the west and the Adriatic to the east. ${ }^{122}$ At the beginning of the fifth century, Ravenna was essentially in ruins, which added to its desirable qualities; it was a clean slate upon which an imperial capital could be built ex novo. However, during the early and high Imperial period, Ravenna was known for its naval base that was established during the Augustan period. ${ }^{123}$ In point of fact, this naval base was located in the neighboring town of Classe, which boasted a substantial population well into the late antique period. The two urban centers were connected by a canal called the Fossa Augusta. (fig. 11) This canal, along with another smaller port closer to the center of Ravenna, essentially connected the city to the other urban centers of the Adriatic, which included the cities of the Istrian peninsula located on the northern part of the Dalmatian coast.

The population of Ravenna suffered a significant decline during the third and fourth centuries, and it was not until Honorius moved the western capital there that the population began to rebound. The relatively ruinous state of Ravenna's urban center upon the arrival of the imperial court allowed for the construction of a new capital, a

\footnotetext{
${ }^{121}$ Deborah Mauskopf Deliyannis, Ravenna in Late Antiquity (Cambridge: Cambridge University Press, 2010): 18.

${ }^{122}$ Ibid., 46.

${ }^{123}$ Ibid., 27.
} 
sedes imperii, that rivaled Milan, Rome, and even Constantinople. ${ }^{124}$ The layout of the new capital was similar to both Milan and Constantinople and housed approximately fifteen-hundred government officials with a total population reaching five-thousand to ten-thousand. ${ }^{125}$ The construction of a new imperial palace, referred to as "At the Laurel," recalls the Constantinian "Palace of Daphne" in Constantinople. ${ }^{126}$ Moreover, Agnellus, the ninth-century author of the Liber Pontificalis Ravennatis, uses the words "ad Calchi" in reference to the monumental gate of the imperial palace, which recalls the Chalke from the Great Palace in Constantinople. ${ }^{127}$ It should be noted, however, that "Ravenna was not simply a pale imitation of the eastern capital, but a place in which new ideas and elements were introduced into the imperial repertoire."128

According to Agnellus, much of this new construction took place during the reign of Valentinian III and his mother, Galla Placidia. ${ }^{129}$ The influence of this imperial matriarch on fifth-century Ravenna cannot be overestimated. Due to Valentinian III's young age, his mother acted as regent and was responsible for an extensive building program. Galla Placidia, the half-sister of Honorius and Arcadius, was the only daughter of Theodosius I. She was raised in the household of Stilicho, the prominent general and consul of the western empire, and was twenty years old at the time of the Visigothic sack of Rome in $410 .{ }^{130}$ In 414, as a result of the attack, Galla Placidia was taken hostage and

\footnotetext{
${ }^{124}$ Deliyannis (2010): 48.

125 Ibid., 49.

126 Ibid., 56.

127 Ibid., 56.

128 Ibid., 51.

${ }^{129}$ According to Agnellus, there were churches built during the Honorian period, but archaeological evidence points to only a single martyrial basilica dedicated to St. Lawrence that was located outside the city walls. See Deliyannis (2004): 136; and Deliyannis (2010); 61-62, and 51.

130 Ibid., 44.
} 
forced to marry the Visigothic leader, Ataulf. ${ }^{131}$ After a brief stay in Spain and upon the assassination of her husband, Galla Placidia returned to Honorius's court in 416 on the condition that she was to marry a prominent military commander named Constantius III. ${ }^{132}$ When Constantius III unsuccessfully tried to assassinate Honorius in 421, Honorius subsequently had him assassinated and forced his half-sister and her two children, Iusta Grata Honoria and Valentinian III, to leave Ravenna and reside in the imperial court at Constantinople under the supervision of their nephew, Theodosius II. ${ }^{133}$ Two years later Honorius died and Theodosius II appointed Valentinian III as his successor and Galla Placidia as regent. ${ }^{134}$

During the trip back to Ravenna, Galla Placidia's boat encountered a violent storm, which caused her to pray to St. John the Evangelist for a safe return. Her prayers were answered and she dedicated her first church in Ravenna to San Giovanni Evangelista. ${ }^{135}$ Galla Placidia remained at the forefront of Ravennate politics from 425 until Valentinian married Theodosius II's daughter, Licinia Eudoxia, in 437. During this period, Galla Placidia was one of the major patrons of lavish Christian churches in Ravenna, which, in addition to the large basilica of San Giovanni Evangelista, included the church of Santa Croce with its side chapel dedicated to St. Lawrence, commonly referred to as the "Mausoleum of Galla Placidia." 136

The bishops of fifth-century Ravenna, in addition to Galla Placidia, provided the flourishing imperial city with a series of large ecclesiastical complexes. According to

\footnotetext{
${ }^{131}$ Deliyannis (2010): 44.

${ }^{132}$ Ibid., 44.

${ }^{133}$ Ibid., 44.

${ }^{134}$ Ibid., 44.

${ }^{135}$ Ibid., 63.

${ }^{136}$ For a full discussion of these churches see ibid., 63-84.
} 
Agnellus, Christianity's origins in Ravenna date to the apostolic period with the Bishop Apollinaris. ${ }^{137}$ However, the first documented evidence of an episcopate in Ravenna dates to the mid-fourth century with Bishop Severus, while the first Episcopal building programs were built under the patronage of Bishop Ursus in the fifth century. ${ }^{138}$ The construction of the city's cathedral, the Ursiana with its neighboring baptistery, and the Episcopium's "location at the eastern edge of the former oppidum, provided the city with two poles of authority: the emperor to the east and the bishop to the west." ${ }^{\text {,139 }}$ (fig. 12)

The Orthodox nature of these fifth-century churches, while not apparent in terms of architecture or decoration, existed in the religious allegiance of their patrons. Galla Placidia and the bishops of fifth-century Ravenna were, like the emperor in the East, fiercely Orthodox. Galla Placidia's father, Theodosius I, proclaimed Christianity as the state religion in 380, while his grandson, Theodosius II, emphasized the Orthodoxy of imperial Christianity as a result of the Council of Ephesus in 431. The fifth-century ecclesiastical spaces of Ravenna, while not visibly Orthodox, do exhibit classicizing tendencies, which will be discussed below. As demonstrated in Constantinian Rome and Ambrosian Milan, evoking the legitimacy and prestige of the classical past was an effective way of proclaiming political and religious authority for the future. After Ravenna fell into the hands of the Ostrogoths in the late-fifth century, Arian-sponsored monuments with deliberately classicizing architectural plans and decoration were constructed.

\section{Sixtus III and his "Renaissance"}

\footnotetext{
${ }^{137}$ For a translation of the original text see Deliyannis (2004): 101-104.

${ }^{138}$ Ibid., 4.

${ }^{139}$ Deliyannis (2010): 85.
} 
The religious debates that raged throughout the fourth and fifth centuries came to a head at the Council of Ephesus in 431, which clearly articulated the Orthodox position of Christ's nature as being both human and divine through the proclamation of the Virgin as the Theotokos, or "God-Bearer." While Orthodoxy was further solidified at the Council of Chalcedon in $451 \mathrm{CE}$, it did not mean that the Nestorian or Arian heresies were permanently stamped out, as we will see during the late-fifth and early-sixth centuries in Ostrogothic Ravenna. However, the reassertion of Orthodoxy became physically apparent through the implementation of classical architectural and decorative trends in the built environment of post-Ephesian Rome.

In the aftermath of the Council of Ephesus, there was a rise in monumental church architecture dedicated to the Virgin. The consecration of the church of Santa Maria Maggiore during the papacy of Sixtus III, shortly after the Council of Ephesus in 431, illustrates the burgeoning devotion to the Virgin as well as the triumph of Orthodoxy, through its employment of the traditional Roman basilica-style. According to Margaret Miles, the church's "plan was based on Hellenistic principles stated by Vitruvius at the time of Augustus" and was, for some time, thought to be a renovation of an earlier Imperial temple on that site from the second century. ${ }^{140}$ The original interior consisted of a nave and two side aisles divided by two Ionic colonnades of forty columns each, made of marble and granite. ${ }^{141}$ (fig. 13) Certainly, basilica-style churches were common during this period, but their naves were usually divided by two rows of columns topped with arcades, which can be seen in the nearly contemporary Church of Santa Sabina located on the Aventine Hill. (fig. 14) The use of the colonnade at Santa Maria

\footnotetext{
${ }^{140}$ Margaret R. Miles, "Santa Maria Maggiore's Fifth-Century Mosaics: Triumphal Christianity and the Jews," The Harvard Theological Review 86:2 (1993): 158.

${ }^{141}$ Ibid., 158.
} 
Maggiore is, therefore, unique, and has more in common with Imperial Roman architecture than the Christian architecture of the fifth-century. Classicizing elements can also be found in the architectural decoration, which included an extensive mosaic program, expensive marble revetment, and vegetal motifs rendered in stucco. ${ }^{142}$ The deliberately classicizing qualities of this monumental fifth-century church, viewed within the context of the triumph of Orthodoxy at the Council of Ephesus, led to what scholars have identified as the "Sixtine Renaissance." "143

The continuation of these styles after the papacy of Sixtus III bolsters the notion of a fifth-century renaissance. Krautheimer discusses the conservative nature of these monuments and ascribes them to the overwhelming aura of classicism that was still present in Rome during the fifth century. ${ }^{144}$ It is important to note that by this time, the bonds that tied the architectural trends to classical antiquity and traditional Roman religious practices had been severed. ${ }^{145}$ In addition, the Visigothic sack of Rome in 410 was still fresh in the minds of its citizens and, according to Krautheimer, the Sixtine Renaissance illustrated the moment at which the Roman apostolic See stepped into the power vacuum created by the absence of a Roman political machine. This space allowed for the continuation of traditional Roman culture from a distinctly Christian perspective. ${ }^{146}$ He also states that this was a uniquely Roman phenomenon and one that was not present in the "more progressive employment of classicizing motifs found in

\footnotetext{
${ }^{142}$ Richard Krautheimer, "The Architecture of Sixtus III: A Fifth-Century Renascence?" Essays in Honor of Erwin Panofsky ed. Millard Meiss (New York: New York University Press, 1961): 291-302.

${ }^{143}$ Ibid., 291-302.

${ }^{144}$ Recently, scholars have refined Krautheimer's arguments. Most notably, in Maria Fabricius Hansen, The Eloquence of Appropriation: Prolegomena to an Understanding of Spolia in Early Christian Rome (Rome, L'Erma di Breschneider, 2003): 276-278. For the original argument, which is presented here, see Krautheimer (1961): 296.

${ }^{145}$ Krautheimer (1961): 301.

${ }^{146}$ Ibid., 302.
} 
Ravenna and Constantinople," which did not "cling as slavishly" to traditional models. ${ }^{147}$ However, these carefully constructed reassertions of Rome's classical past, which were visually manifest in the physical environment through the employment of classicizing motifs, gave way to the increasing stylization that becomes pervasive during the sixth century after the rise of Justinian and the transition to the Byzantine style.

${ }^{147}$ Krautheimer (1961): 296. 


\section{CHAPTER 5}

\section{CLASSICIZING PLASTER: STUCCOWORK FROM THE FOURTH AND FIFTH CENTURIES IN ROME, MILAN, AND RAVENNA}

Stuccowork from the fourth and fifth centuries can be divided into two iconographical types. The first, and most common, consists of geometric and vegetal motifs that often appeared in low-relief on the interior entablatures and cornices of ecclesiastical monuments. The second type is characterized by figural elements found primarily in the chapels, tombs, churches, and baptisteries of the Italian peninsula. Both categories of stuccowork were part of an overall decorative program that included mosaics, frescoes, marble revetment, and opus sectile. The classicizing nature of these decorative programs illustrates the desire to evoke the prestige of the classical past that legitimated the patronage and construction of Christian sacred spaces during the fourth and fifth centuries.

\section{San Lorenzo, Milan}

The earliest extant examples of late antique stuccowork are found in the Church of San Lorenzo, Milan (late fourth or early fifth centuries). ${ }^{148}$ (fig. 15) For decades scholars have debated the chronology of this church. Some have assigned a preAmbrosian foundation on the site to the reign of Constantius II and his Arian bishop, Auxentius, while others favor a Theodosian date that coincides with the episcopacy of

\footnotetext{
${ }^{148}$ Pasquini (2002): 105.
} 
Ambrose. ${ }^{149}$ For the purposes of this study a decision is not necessary, because, in either case, the church was an imperial foundation. The architectural plan, an elaborate doubleshell quatrefoil, is similar in design to Constantine's Golden Octagon in Antioch, a form that was copied throughout the late antique and early Byzantine periods. The proximity of the Milanese church to the nearby palatine residence also supports an imperial foundation. However, the architectural design, combined with the classicizing nature of the architectural decoration that included mosaic, marble revetment, opus sectile, and stuccowork illustrates a wish to evoke Constantine's Christian appropriation of classical antiquity which aligned with Ambrose's imperial ambitions.

As a result of extensive renovations during both the Romanesque and Renaissance periods, the original decorative programs no longer survive in large quantities. However, during restoration work in the late-1930s, two fragments of late-fourth or early-fifth century stuccowork were uncovered. ${ }^{150}$ The first fragment was discovered on the soffit of an arch located north of the entrance to the Sant'Hippolytus chapel, a subsidiary chapel located on the western side of the church. (fig. 16) This fragment contains a vegetal and floral motif which includes a rosette embedded within a bundle of elongated leaves, a motif, as Pasquini points out, that is strikingly similar to the soffit mosaics of the so-called Mausoleum of Galla Placidia. ${ }^{151}$ The second, less conspicuous, fragment was found in the entryway to the chapel of Sant'Aquilino. (fig. 17) This fragmentary

\footnotetext{
${ }^{149}$ For pre-Ambrosian dating see W. Eugene Kleinbauer, "Toward a dating of San Lorenzo in Milan: Masonry and Building Methods of Milanese Roman and Early Christian Architecture," Arte Lombarda XMII (1968): 1-22; and Dale Kinney, "The Evidence for the Dating of S. Lorenzo," Journal of the Society of Architectural Historians 31 (1972): 92-107; and for a Theodosian context see Suzanne Lewis, "San Lorenzo Revisited: A Theodosian Palace Church at Milan," Journal of the Society of Architectural Historians 32 (1973): 197-222.

${ }^{150}$ Pasquini (2002): 205.

${ }^{151}$ Ibid., 205.
} 
cornice, now destroyed, consisted of a traditional egg-and-dart motif, which was a common framing device used throughout classical antiquity.

Due to the fragmentary nature of the stucco decoration, it is difficult to reconstruct the stuccowork program of this church. However, the presence of the decorative material, alongside mosaic and marble installations, attests to its popularity (at all social levels) during the late antique period. It is important to note that these stuccoes were found near or in the entryways of two side chapels that were added after the initial construction of the church in the late-fourth century. The location of the stuccoed soffit, on an arcade that is inside the main structure, points to a late-fourth century date. (fig. 16) The egg-and-dart cornice fragment, however, was found in the entryway of the chapel of Sant'Aquilino, a chapel that has been dated, based on mortar analysis, to a second building phase during the early-fifth century. ${ }^{152}$ (fig. 17) Based upon this information, we can deduce that some form of stucco decoration was present in the structure as early as the first construction of the building during the late-fourth century. The controversial dating of this church to either an Arian foundation under Constantius II, as proposed by Kleinbauer, or a slightly later Orthodox establishment under Theodosius I, as posited by Lewis, has no relevance for the analysis of its stuccowork programs. The notion that decorative programs are not subject to differences based on religious affiliation, is significant and will be revisited in the stuccowork of fifth-century Ravenna.

\footnotetext{
${ }^{152}$ Kleinbauer (1968): 18; and Lewis (1973): 199.
} 


\section{Santa Maria Maggiore, Rome}

In Rome, fifth-century stuccowork was discovered at Santa Maria Maggiore during restoration work in $1928{ }^{153}$ The dating of this church, unlike San Lorenzo, is not controversial; the textual and archaeological evidence points to a foundation during the papacy of Sixtus III (432-440). ${ }^{154}$ The construction of a monumental basilica-style church dedicated to the Virgin illustrates the triumph of Orthodoxy after the Council of Ephesus in 431. At this council, the hypostatic union of Christ's dual-natures was solidified through the proclamation of the Virgin as the Theotokos, or the bearer of God. ${ }^{155}$ Sixtus III chose a traditional basilica-style church to celebrate this victory and installed an elaborate decorative program, which contained a variety of classicizing elements. While the mosaics of Santa Maria Maggiore have been thoroughly examined, the decorative program also included the installation of stuccowork. ${ }^{156}$

While the full extent of the original stuccowork program is unknown, discovery of a fragmentary stuccowork frieze along both the north and south walls of the nave, which adorned the entablature and was placed immediately below the roof trusses, allows

\footnotetext{
${ }^{153}$ For the discovery of the fragmentary frieze see Massimo Bonelli, "Rilevamento delle decorazioni in stucco altomedievali di Roma," Roma e l'età Carolingia (Roma: Multigrafica Editrice, 1976): 304-305; and Pasquini (2002): 71. In addition to this frieze, Krautheimer discussed the possibility that the sixteenthcentury stucco pilasters and frames, which surround the mosaic panels of the nave, were restorations of fifth-century stuccowork. For this see Krautheimer (1942): 378.

${ }^{154}$ The ninth-century Liber Pontificalis Romani discusses a fifth-century date that corresponds to both the dedicatory inscription that reads, "XYTVS EPISCOPVS PLEBI DEI" (Sixtus Bishop of the People of God) and the mortar analysis undertaken by Krautheimer. See Richard Krautheimer, "The Architecture of Sixtus III: A Fifth-Century Renascence?" Essays in Honor of Erwin Panofsky ed. Millard Meiss (New York: New York University Press, 1961): 291; and Richard Krautheimer, "Recent Publications on S. Maria Maggiore in Rome," American Journal of Archaeology 46:3 (1942): 373-379.

155 J.N.D. Kelly, Early Christian Doctrines (New York, Harper \& Row, Publishers: 1978): 325.

${ }^{156}$ For discussions of these mosaics see Suzanne Spain, “"The Promised Blessing': The Iconography of the Mosaics of Santa Maria Maggiore," Art Bulletin 61 (1979): 518-540; and Margaret R. Miles, "Santa Maria Maggiore's Fifth-Century Mosaics: Triumphal Christianity and the Jews," The Harvard Theological Review 86:2 (1993): 155-175.
} 
for a partial reconstruction. ${ }^{157}$ Two fragmentary sections of the frieze survive, only one dates to the original fifth-century construction which was found below the sixteenthcentury wooden frieze. ${ }^{158}$ (fig. 18) The fragment's poor state of preservation only hints at the original design. The use of swirling acanthus leaves, applied in low relief, recalls classical architectural decoration. While traces of paint or gilt do not survive, it is likely that the frieze had both. Krautheimer contextualizes the "classical conservatism" of the church's decorative program alongside other Sixtine monuments, especially the Lateran Baptistery. ${ }^{159}$ According to Krautheimer, the continuation of this "classical conservatism" after the death of Sixtus III confirms the notion of the "Sixtine Renaissance," 160 which, in turn, supports the late antique desire to evoke the legitimacy and prestige of the classical past.

The stuccowork frieze, placed near the roof-line, would have been the threedimensional element that balanced the two-dimensional nature of the mosaics below. It is its three-dimensional quality that made stuccowork significantly different from mosaic, marble revetment, or opus sectile. An important consideration, however, is why this material was chosen over marble sculpture. The lavish nature of the decorative program, which included a large amount of marble sculpture, indicates that cost was not a factor. It is more likely that the unique benefits of stucco, specifically its adaptability and lightweight quality, were favored over the rigidness and heavy weight of a sculpted marble frieze. The installation of this three-dimensional decorative frieze, at the highest point in the nave, required the use of a material that was lightweight so that it would not

\footnotetext{
${ }^{157}$ Pasquini (2002): 71.

${ }^{158}$ Ibid., 71.

${ }^{159}$ Krautheimer (1961): 292.

${ }^{160}$ Ibid., 293.
} 
detach from the wall, a quality that marble sculpture lacked. Additionally, the use of a lightweight material such as stucco could allow for a higher relief, which would have been more easily visible from the floor.

\section{Mausoleum of Quirinus of Sescia, San Sebastiano, Rome}

The most extensive program of late antique stuccowork to survive in Rome is found in the mausoleum dedicated to Quirinus of Sescia, located on the southeastern side of the Church of San Sebastiano. ${ }^{161}$ This Constantinian funerary church was built over a series of catacombs that bear the same name. A few decades after the initial construction in the first half of the fourth-century, an ancillary building was erected, during the pontificate of Damasus (366-384), behind the church's apse on the southeastern slope. ${ }^{162}$ (fig. 19) The dedication of this mausoleum to the early-fourth century martyr, Quirinus of Sescia, illustrated the sanctity of the site, which had been associated with the relics of both Peter and Paul prior to their transfer to Old St. Peter's and the Via Ostiensis, respectively. ${ }^{163}$

The mausoleum is semi-circular in plan and originally contained fourteen arcosolia along its interior, two of which were destroyed during later renovations. ${ }^{164}$ (figs. 20 and 21) From the fragmentary remains of polychrome stucco found on the interior and exterior of at least three of the niches, scholars have inferred that stuccowork was originally present in all fourteen arcosolia. ${ }^{165}$ The majority of the mausoleum's extant stuccowork exhibits various geometric and floral motifs, which decorate the

\footnotetext{
${ }^{161}$ Bonelli (1976): 302-303; and Pasquini (2002): 73.

${ }^{162}$ Krautheimer (1937-1977): vol. V 103-104.

${ }^{163}$ Ibid., 102.

${ }^{164}$ Pasquini (2002): 74.

${ }^{165}$ Bonelli (1976): 302-303; and Pasquini (2002): 74.
} 
exterior and interiors of the arcosolia. A relatively well-preserved set of stuccos is found on the exterior of niche \#12. The fragmentary stuccowork of this arcade contains a stylized, fluted Corinthian column with a decorative cornice and a portion of the corner, which is decorated with a garland punctuated with a four-petalled flower that is surrounded by a delicately incised ribbon motif. (fig. 22) Stuccowork from the interior of these arcosolia can be seen in two unidentified niches, which contain repeating geometric and floral patterns. The first fragment exhibits a repeating pattern of flowers surrounded by stylized leaves within an octagonal frame that is formed by a beaded motif. (fig. 23) A similar pattern is found on another niche, albeit with a rectilinear pattern that is devoid of any floral elements. (fig. 24) However, this fragment is significant due to a set of three fragmentary beaded stucco frames, which are found on the upper part of the back of the niche. While these frames are empty, we can surmise that they would have contained imagery similar to the stuccoes found in niche \#7. This niche, located to the left of the eastern entrance, contains a set of three fragmentary beaded stucco frames. ${ }^{166}$ While the contents of the two side frames no longer survive, the central frame contains the remains of a standing man wearing a toga who holds up his right arm and extends an open palm. (fig. 25)

The stuccowork programs of this mausoleum have been dated, based on style, to the fifth century. ${ }^{167}$ While the patron is unknown, the use of traditional motifs places it within the same context as the fifth-century stuccowork of Santa Maria Maggiore. The conservative nature of these motifs, both figural and non-figural, recall the Roman imperial stuccowork discussed in Chapter 3. Additionally, the inclusion of a standing

\footnotetext{
${ }^{166}$ Bonelli (1976): 302; and Pasquini (2002): 74.

${ }^{167}$ Bonelli (1976): 303; and Pasquini (2002): 76.
} 
male figure who wears a toga is similar to the standing figures located in the Tomb of the Valerii (Tomb H) of the Vatican Necropolis, which dates to 160 CE. ${ }^{168}$ (fig. 26) This bearded figure, who stands atop a pedestal, placed within a semi-circular niche is strikingly similar to the figural stuccowork of Ravenna, which also dates to the fifthcentury.

The stuccoes from the Mausoleum of Quirinus have, appropriately, been compared to the lavish stuccowork program of the Neonian Baptistery. ${ }^{169}$ Pasquini goes further in comparing them to the stuccowork of the sixth-century Basilica Eufrasiana in Poreč. ${ }^{170}$ These comparisons are problematic because the stuccoes of Poreč are nonfigural in nature and were installed in a significantly different historical context. I propose that the installation of figural stuccowork was a trend that continued from Classical antiquity into the fourth and fifth centuries. It is the sixth century, with the expansion of Constantinopolitan influence, which was characterized by a greater focus on the stylization of form and environmental setting that might explain the decline in the use of figural stuccowork.

\section{Ursiana Cathedral, Ravenna}

The establishment of Ravenna as a metropolitan see during the first half of the fifth century led to the construction of an ecclesiastical complex that included the city's cathedral, which, according to Agnellus, was built during the episcopate of Ursus (405431). ${ }^{171}$ The church, which no longer survives, is known only through textual sources

\footnotetext{
168 Allag and Blanc (2006): 109.

${ }^{169}$ Bonelli (1976): 303; and Pasquini (2002): 75-76.

170 Pasquini (2002): 75.

${ }^{171}$ Deliyannis (2010): 85-86.
} 
and eighteenth-century drawings made during its demolition. ${ }^{172}$ These sources have led scholars like Paola Novara to reconstruct the church as a double-aisled basilica with an eastern semi-circular apse. ${ }^{173}$ (fig. 27) According to Deliyannis, the Ursiana measured approximately 60 x 35 meters and was slightly smaller than both the Lateran in Rome and the Ambrosian cathedral of Milan. The similar layout of these three cathedrals points to the conservative nature of the architecture that was favored in these orthodox ecclesiastical complexes. ${ }^{174}$

Due to the lack of surviving material remains of this cathedral, our only evidence for its decorative program is found in Agnellus' Liber Pontificalis Ravennatis. In this text, which is based on the Liber Pontificalis of Rome, Agnellus identifies the workers responsible for the decorative stuccowork program. He writes:

"Euserius and Paul decorated one wall surface, on the north side, next to the altar of St. Anastasia, which Agatho made. That is the wall where columns are placed in a row up to the wall of the main door. Satius and Stephen decorated the other wall on the south side, up to the above-mentioned door, and here and there they carved in stucco different allegorical images of men and animals and quadrupeds, and they arranged them with the greatest skill."175

It is difficult to reconstruct the layout of this stuccowork program from an absence of material evidence. However, it should be recognized that, because Agnellus made a point to describe the material, it is reasonable to assume that the cathedral contained some form of sculptural stucco that included human and animal imagery. This hypothesis is bolstered by the discovery of comparable human and animal sculptural stucco fragments during the excavation of the fifth-century Ravennate church of Santa Croce.

\footnotetext{
172 Deliyannis (2010): 87.

173 See Paola Novara, La cattedrale di Ravenna: storia e archeologia (Ravenna: D. Montanari, 1997): 6870; and Paola Novara, “ La Ravenna tardo imperiale,” Ravenna Romana ed. Maurizio Mauro (Ravenna: Adriapress, 2001): 263-265.

${ }^{174}$ Deliyannis (2010), 86.

175 Deliyannis (2004), 118-119.
} 


\section{Santa Croce and the so-called Mausoleum of Galla Placidia, Ravenna}

Excavations at Santa Croce, located in the northwestern part of the city, began during the mid-nineteenth century. However, the excavations of 1967-1980 and the 1990s have provided scholars with a wealth of information that includes a reliable chronology of the church's construction, its original plan, and a portion of the original decorative program. ${ }^{176}$ According to the most recent excavations conducted by Gelichi and Novara, the church dates to the triumphant return of Galla Placidia from Constantinople, sometime after $425 .{ }^{177}$

The aiseless basilica-style church includes an eastern transept that transformed the traditional longitudinal space into a Latin-cross plan. (fig. 28) The architectural precedents for this church are the churches of Ambrosian Milan, which include the Basilica Apostolorum and the Basilica Virginium, both based on a Latin-cross plan, and which, in turn, are closely related to Constantine's Apostoleion in Constantinople. ${ }^{178}$ The dedication of Santa Croce was, according to scholars, a result of Galla Placidia's connection to the Holy Cross, a symbol that came to represent the Theodosian Dynasty. ${ }^{179}$ The symbolism of the Latin cross is further emphasized by the addition of at

\footnotetext{
${ }^{176}$ Friedrich Wilhelm Deichmann, Ravenna, Hauptstadt des spätantiken Abendlandes (Weisbaden: F. Steiner, 1974): 51-59; Cortesi (1978): 47-76; Sauro Gelichi and Paola Novara, "La Chiesa di Santa Croce a Ravenna: la sequenza architettonica," Corso di cultura sull'arte ravennate e bizantina 42 (1995): 347-382. ${ }^{177}$ Deliyannis (2010): 74; and Gelichi and Novara (1995): 357.

${ }^{178}$ Deliyannis (2010): 70; Christie (2006): 109; and Doig (2009): 58.

${ }^{179}$ This is evident in the coinage of Theodosius II, Pulcheria, Honorius, Iusta Grata Honoria, Valentinian III, and Galla Placidia. See Deliyannis (2010): 83; Kenneth Holum, "Pulcheria's Crusade A.D. 421-22 and the Ideology of Imperial Victory," Greek, Roman, and Byzantine Studies 18: 153-172; and Kenneth Holum, Theodosian Empresses: Women and Imperial Dominion in Late Antiquity (Berkeley: University of California Press, 1982): 110.
} 
least one cruciform chapel, dedicated to St. Lawrence, at the southern end of the church's narthex. ${ }^{180}$

The chapel, which became known as the Mausoleum of Galla Placidia in the thirteenth century, remains completely intact and contains the most extensive fifthcentury decorative program in the city of Ravenna. ${ }^{181}$ The lavish quality of the decorative program, which dates to the original construction of the main church, provides scholars with a model upon which a reconstruction of the church's decorative program can be based. The imperial patronage of this church complex is apparent in the sumptuous nature of the materials used, which included opus sectile, marble sculpture, marble revetment, mosaics, and sculptural stuccowork. It contains each of these materials with an emphasis on the marble revetment and the elaborate mosaic program. However, a plain stuccowork cornice between the marble revetment and the mosaics acts as a visual, three-dimensional barrier between the field of smooth marble below and the two-dimensional mosaics above. (fig. 29)

The stuccowork uncovered during the excavations of Santa Croce reveals an elaborate program that included architectural, animal, and figural elements. A complete reconstruction of the stuccowork program is difficult, due to the fragmentary nature of the material evidence, which is no longer attached to architectural elements, thus making it impossible to assign a place to the fragments within the structure. Nevertheless, the large amount of stuccowork uncovered can be divided into four main groups according to their find spots: the first group was found in the area of the southern porch, which abutted

\footnotetext{
${ }^{180}$ Scholars propose the existence of a second cruciform chapel which would have been located at the northern end of the narthex. However, recent studies have shown that there is a lack of archaeological evidence for this structure. See Gelichi and Novara (1995): 347-382.

${ }^{181}$ Deliyannis (2010): 74.
} 
the south wall of the nave; the second group was found around the exterior of the original apse; the third group was found near the northeast corner of the apse, and the fourth group was found in the northern arm of the transept that led to the exterior of the church. $^{182}$

Unfortunately, Pavan does not provide an archaeological context for the stucco remains within the structure, which further emphasizes the difficulty in creating an accurate reconstruction. However, Pavan does provide detailed discussions of numerous fragments, which he divides into groups corresponding to their type. ${ }^{183}$ These types include cornices, engaged columns, pilasters, animals, and human figures. He identifies at least four different styles of cornices that range in size from $2.5 \mathrm{~cm}$ to $12.7 \mathrm{~cm}$ high, which consisted of egg-and-dart, Greek meander, floral, and geometric motifs. ${ }^{184}$ (fig. 30) At least four different styles of engaged columns and pilasters were identified, that included Corinthian capitals with either simple-fluted, spiral-fluted, or foliate shafts. ${ }^{185}$ (fig. 31) A reconstruction of a quadruped and a standing toga-clad figure indicates the possibility of some sort of figural scene. ${ }^{186}$ (fig. 32)

The stylistic similarity between the figural stuccowork fragments of Santa Croce and the figural mosaics of the Mausoleum of Galla Placidia points to a connection between the two materials. (fig. 29) This connection is strengthened by the presence of pigment on several stucco fragments, which indicates the polychromy of the original

\footnotetext{
${ }^{182}$ Pavan (1980): 144.

${ }^{183}$ Ibid., 146-161.

${ }^{184}$ Ibid., 146-150.

${ }^{185}$ Ibid., 153-158.

${ }^{186}$ Pasquini (2002): 125.
} 
installation. ${ }^{187}$ Therefore, I suggest that the stuccowork program of Santa Croce was intended to be viewed as a form of three-dimensional mosaic.

The classical nature of the motifs, both figural and non-figural, recalls the stuccowork in both Milan and Rome. Specifically, the inclusion of a standing figure wearing a toga is reminiscent of the standing figure of niche \#7 in the Mausoleum of Quirinus at San Sebastiano. A question that arises concerns why the figural stuccowork is restricted to the main church and not included in the Mausoleum of Galla Placidia. Without precise location for the figural stuccowork inside Santa Croce, it is impossible to answer this question. However, the connection between the figural stuccowork in Rome and what was uncovered at Santa Croce illustrates a trend that favors figural stuccoes, a hypothesis that is bolstered by the monumental figural stuccowork program of the Neonian (Orthodox) Baptistery.

\section{Neonian (Orthodox) Baptistery, Ravenna}

The most extensive examples of late antique stuccowork in the Mediterranean are found in the Neonian Baptistery in Ravenna. ${ }^{188}$ This baptistery, erected by Bishop Ursus (405-431), was extensively remodeled and redecorated by Bishop Neon (450-473). ${ }^{189}$

The structure is octagonal in plan and is architecturally similar to the late antique

\footnotetext{
${ }^{187}$ Pavan (1980): 148.

${ }^{188}$ The decision to use the term "Neonian" in reference to the Orthodox Baptistery of Ravenna is to acknowledge the renovation of the building, which included the installation of the monumental stuccowork program, during the episcopate of Neon (450-473).

${ }^{189}$ Kostof (1965): 12-13; Deichmann (1974): 21-22; Laura Pasquini (2002): 27; Laura Pasquini, "Il battistero della cattedrale cattolica," Venezia e Bisanzio: Aspetti della cultura artistica bizantina da Ravenna a Venezia (V-XIV secolo) ed. Clementina Rizzardi (Venice: Istituto Veneto di scienze, lettere ed arti, 2005): 327; Eugenio Russo, "L'Architettura di Ravenna paleocristiana," Venezia e Bisanzio: Aspetti della cultura artistica bizantina da Ravenna a Venezia (V-XIV secolo) ed. Clementina Rizzardi (Venice: Istituto Veneto di scienze, lettere ed arti, 2005): 89-103; Deliyannis (2010): 92.
} 
baptisteries in Rome, Milan, and Aquileia. ${ }^{190}$ (fig. 33) The popularity of the octagonal plan for these buildings is closely tied to the theology of Ambrose who "identified the number 8 as symbolic of baptism, because it corresponds to the Resurrection of Christ that took place on the eighth day." ${ }^{\text {"191 }}$ Additionally, these octagonal buildings were recollections of Roman bathing complexes, by their association with water, and to imperial mausolea, by their association with spiritual death and subsequent Christian rebirth. ${ }^{192}$

The major structural change that occurred, as a result of the Neonian renovation, was the removal of the original timber vault and the construction of a shallow dome that measures $9.6 \mathrm{~m}$ in diameter and rises to a height of $14.6 \mathrm{~m}$ above the original floor. ${ }^{193}$ (fig. 34) It should be noted that the current floor level is $3 \mathrm{~m}$ above the original, which was raised c. $1000 \mathrm{CE}$ to compensate for the rising water table. ${ }^{194}$ In addition to these structural changes, Neon commissioned a new decorative program that consisted of opus sectile on the lower walls, followed by a zone of monumental stuccoes, and topped with a brightly colored mosaic program in the dome that depicted a procession of the twelve apostles and the baptism of Christ. ${ }^{195}$ (fig. 35) These decorative changes were, again, described by Agnellus who writes: "He decorated the baptisteries [sic] of the Ursiana

\footnotetext{
${ }^{190}$ Annabel J. Wharton, "Ritual and Reconstructed Meaning: The Neonian Baptistery in Ravenna," The Art Bulletin 69:3 (1987): 358; Deliyannis (2010): 89.

${ }^{191}$ Deliyannis (2010): 89.

192 Ibid., 89.

${ }^{193}$ Kostof describes this dome as a baldacchino that is draped over the interior space which is supported not by the exterior walls but by the use of arches and columns placed at the level of fenestration. See Kostof (1965): 42-43.

${ }^{194}$ Ibid., 44-45; Deliyannis (2010): 93.

${ }^{195}$ For a full discussion of these mosaics see Kostof (1965): 76-93 and 100-123;
} 
church most beautifully: he set up in mosaic and gold tesserae the images of the apostles and their names in the vault, he girdled the side-walls with different types of stones." ${ }^{196}$

The monumental stucco decoration, located above the opus sectile and below the dome mosaics, fills the spaces between the eight windows that puncture each wall of the baptistery. (figs. 36 and 37) The program is broken up by the broad arches that support the dome. Each of these broad arches covers a tripartite arcade whose soffits exhibit motifs of birds, rosettes, and grain made entirely of stucco. (fig. 38) Located on either side of the large windows, sixteen architectural niches, sculpted in low relief, are separated by twenty-four reused, and therefore unmatched, slender Ionic colonnettes. To create a sense of unity, these colonnettes were coated with plaster and painted to imitate costlier marbles, a technique that was common in the late antique period. ${ }^{197}$ Each of these niches is constructed of stucco fluted pilasters topped with stylized Corinthian capitals, which support alternating rounded and pointed pediments. The rounded pediments contain downturned scallop shells and the pointed pediments contain upturned scallops, all of which are sculpted in higher relief.

Located inside each of the sixteen elaborate niches stands a figure clad in a billowing pallium who holds either a codex or scroll. Below is an inventory of these

\footnotetext{
${ }^{196}$ Deliyannis (2004): 125.

${ }^{197}$ The recently restored decorative program of the Red Monastery in Sohag, Egypt provides a parallel for this type of technique. For the most recent discussions of this important monument, see Elizabeth Bolman, "The Red Monastery Conservation Project, 2004 Campaign: New Contributions to the Corpus of Late Antique Art," Interactions: Artistic Interchange Between the Eastern and Western Worlds in the Medieval Period, ed. Colum Hourihane (Princeton: Index of Christian Art, 2007): 260-281; idem., "Late Antique Aesthetics, Chromophobia, and the Red Monastery, Sohag Egypt," Eastern Christian Art 3 (2006): 1-24; idem., "The Red Monastery Conservation Project, 2006 and 2007 Campaigns: Contributing to the Corpus of Late Antique Art," Christianity and Monasticism in Upper Egypt vol. 1: Akhmim and Sohag, ed. Gawdat Gabra and Hany N. Takla, Saint Mark Foundation Book (Cairo: American University of Cairo Press, 2008): 305-317; and idem., "Painted Skins: The Illusions and Realities of Architectural Polychromy, Sinai and Egypt," Approaching the Holy Mountain: Art and Liturgy at St Catherine's Monastery in the Sinai, eds. S.E.J. Gerstel and R.S. Nelson (Brepols, forthcoming).
} 
sixteen figures, using the numbering system from Kostof's schematic drawing: ${ }^{198}$ (fig.

37)

1. Short hair; left hand holds open codex; right hand in a gesture of blessing (fig. 39)

2. Short hair; both hands hold closed scroll (fig. 40)

3. Longer hair; left hand holds open codex; right hand in a gesture of blessing (fig. 41)

4. Short hair; both hands hold unfurled scroll (fig. 42)

5. Short hair; both hands hold closed scroll (fig. 43)

6. Short hair; left hand holds open codex; right hand in a gesture of blessing (fig. 44)

7. Short hair; both hands hold unfurled scroll (fig. 45)

8. Short hair; both hands hold closed scroll (fig. 46)

9. Longer hair; left hand holds open codex; right hand is held open (fig. 47)

10. Short hair; both hands hold closed scroll (fig. 48)

11. Longer hair; left hand holds open codex; right hand is held open (fig. 49)

12. Short cropped hair; both hands hold closed scroll (fig. 50)

13. Short hair; left hand holds open codex; right hand in a gesture of blessing (fig. 51)

14. Short hair; both hands hold closed scroll (fig. 52)

15. Longer hair; both hands hold open scroll (fig. 53)

16. Longer hair; both hands hold closed scroll (fig. 54)

Deichmann identifies these sixteen figures as Old Testament prophets and adds them to the eight similarly styled figures rendered in the mosaic spandrels below, and thereby identifies them as the twenty-four elders of the Apocalypse. ${ }^{199}$ Located above these figures, in the awkward space between the pediments and the arches that spring from the plain impost blocks, is a series of twelve paired animals in heraldic composition that confront either vases or flowers. The animals include goats, doves, deer, seahorses, eagles, lions, sheep, roebucks, peacocks, hares, cocks, and pheasants. (fig. 55) The remaining four niches, located on the north and northwest sides, are topped with narrative scenes from both the Old and New Testaments, which include Jonah and the whale; Christ trampling the lion and adder (Christ militans); Christ giving the law to Peter and Paul (the Traditio Legis); and Daniel in the Lion's Den. ${ }^{200}$ (figs. 56-59)

The composition of this stuccowork program, specifically the standing figures within the architectural niches, recalls the tomb decoration of the Mausoleum of Quirinus

\footnotetext{
${ }^{198}$ Kostof (1965): Fig. 41.

199 Deichmann (1974): 30-31.

${ }^{200}$ Deliyannis (2010): 96.
} 
of Sescia and its antecedents from the Tomb of the Valerii in the Vatican Necropolis in Rome. (figs. 25 and 26) Additionally, there are typological similarities between the stuccoes of the Neonian Baptistery and the lavish wall paintings from the Red Monastery in Sohag, Egypt. (fig. 60) The polychrome nature of these paintings, paired with a similar compositional arrangement to the Neonian stuccoes perhaps provides an idea of how the original decoration, whose polychromy was removed during nineteenth and twentieth century renovations, would have appeared. Elizabeth Bolman explicitly connects the wall paintings of the Red Monastery to the "vibrancy, pattern and color" of Ravennate mosaic programs. ${ }^{201}$ She goes on to suggest that these Ravennate antecedents are firmly rooted within the classicizing trend that was widely popular during the late antique period. ${ }^{202}$

Due to the complex nature of the surviving decorative program of the Neonian Baptistery, scholars like Wharton have attempted to reconstruct the rituals associated with late antique baptism, based on the writings of Ambrose. Wharton argues for a close connection between the viewer and the overwhelming nature of the decoration. ${ }^{203}$ She describes how the initiates were brought into the baptistery through one of the original doorways located on the north and west sides. ${ }^{204}$ Then, they were to face west in order to renounce the Devil. ${ }^{205}$ By facing west, the initiates, according to Wharton, would have had a direct view of the four narrative stuccoes showing Jonah and the whale, Christ militans, the Traditio Legis, and Daniel in the Lion's Den. ${ }^{206}$ The choice of these scenes

\footnotetext{
${ }^{201}$ Bolman (2006): 20.

202 Ibid., 20.

${ }^{203}$ Wharton (1987): 358-375.

${ }^{204}$ Ibid., 362.

${ }^{205}$ Ibid., 362.

${ }^{206}$ Ibid., 362.
} 
is related to their association with the triumph over evil, or in the case of the Traditio Legis, a triumph of Christianity over the old law. By the fifth century, these scenes had become visual shorthand for Christians and were used throughout Ravenna, including inside the Archiepiscopal Chapel, a building that is located within the Ursiana complex. (fig. 61) Wharton also makes a connection between the initiates and the sixteen standing figures. She argues that the initiates, after their baptism, would have resembled the standing figures above them who were all clad in similar white garments. ${ }^{207}$

However, these interpretations do not attempt to discuss the choice of stucco as a material for rendering these important figures. To address this issue, we must return to the renovations undertaken by Neon. As discussed above, the major structural renovation of this building was the removal of the wooden vault and the addition of a higher dome, which was not structurally connected to the exterior supporting walls. This dome, which acted more as an interior canopy, similar to a ciborium, was constructed using a system of interlocking tubi fittili, or terracotta tubes. These tubi were placed in decreasing concentric circles until they reached the summit of the dome, where pumice blocks were cemented together in order to complete the structure. (fig. 62) The care taken to create a lightweight dome underscores the concern for collapse due to the relative thinness of the walls below (approximately .6m thick). The builders knew that any decoration placed on the interior walls would have to be relatively lightweight, which effectively ruled out marble sculpture. Kostof notes that the "insertion of a band of decoration in a different medium than mosaic, with its own individual texture and mat [sic] colors, was a happy solution which avoided any monotony of continued and undifferentiated surfaces." ${ }^{208} \mathrm{He}$

\footnotetext{
${ }^{207}$ Deliyannis (2010): 94; and Wharton (1987): 373-374.

${ }^{208}$ Kostof (1965): 99.
} 
also suggests that "the strong light pouring in through the windows [of this zone] would have made the use of mosaic at this level impracticable."209 The choice of stucco, therefore, was both a structural and an aesthetic choice, which allowed for the incorporation of three-dimensional forms that, again, recalled classical trends.

Based upon extant fifth-century Ravennate stuccowork, Kostof suggests that the artists responsible for the installation of the program were from a local stucco workshop who had been at work "since sometime before the refurbishing of the Neonian monument. ${ }^{210}$ Mab van Lohuizen-Mulder took a different approach and suggests that the artists were of Coptic origin, a hypothesis he based on the stylistic similarities between Ravennate and Coptic art, most noticeably in the representation of drapery. ${ }^{211}$ He boldly claimed that Coptic artists "really had something to offer, which was appreciated and that they received some fame because of their skillfulness...proved by the fact that later both a bishop and a caliph invited numerous Copts to help with the rebuilding and building of churches and mosques in Jerusalem." ${ }^{212}$ While there was certainly an independent stuccowork tradition in the Near East, Lohuizen-Mulder's hypothesis that artists of the late antique west abandoned "traditional forms of Hellenistic-Roman heritage... because they carried associations that were no longer desirable" is incorrect. ${ }^{213}$ Pasquini, too, identifies eastern influences specifically from Sasanian Persia in the geometric nature of the drapery. However, she also identifies the

\footnotetext{
${ }^{209}$ Kostof (1965): 99.

${ }^{210}$ This theory directly refutes the earlier suggestions that the stuccoes were a later medieval addition, as posited by Haselhoff. See Haselhoff (1931): 31-32; for Kostof's interpretation, see Kostof (1965): 95.

${ }^{211}$ Lohuizen-Mulder (1990): 139-156.

${ }^{212}$ Ibid., 141. For a brief discussion of the Byzantine employment of Coptic artists in Jerusalem c. 629, see Rina Talgam, The Stylistic Origins of Umayyad Sculpture and Architectural Decoration (Wiesbaden: Harrassowitz Verlag, 2004): 98. For a discussion of the Umayyad employment of Coptic artists in Jerusalem during the reign of al-Walid I (705-715), see ibid., 98; and K.A.C. Creswell, "Coptic Influences on Early Muslim Architecture," Bulletin de la société d'archéologie copte 6 (1938): 29-42.

${ }^{213}$ Lohuizen-Mulder (1990): 141.
} 
standing figures of the Neonian Baptistery as belonging to the iconografica imperiale. ${ }^{214}$ Pasquini's nuanced view of these stuccoes allows for the interpretation of these fully mottled figures as classicizing elements.

When these stuccoes are viewed within the larger context of the Neonian Baptistery's decorative program, one can see the deliberate classicizing nature of the figure-style. This stands in contrast to the mosaics in the dome, which consist of figures that become increasingly dematerialized as they perform their activities of processing or baptism against a plain gold background. ${ }^{215}$ (fig. 38) It is likely that the figures rendered in stucco are meant, as Wharton suggests, to engage in the terrestrial world, while the mosaic figures of the dome move within the celestial one. ${ }^{216}$

The remains of stuccowork from the late antique periods in Milan, Rome, and Ravenna illustrate a trend that was closely connected to classical antiquity. The installation of figural stuccoes, specifically those inside the tombs in Rome, was transferred into the Christian mausolea, basilicas, and baptisteries of the great western capitals. The continued use of this material to render the human form recalled the plastic qualities of classical relief sculpture.

\footnotetext{
${ }^{214}$ Pasquini (2005): 337.

${ }^{215}$ Wharton (1987): 373; and Deliyannis (2010): 94.

${ }^{216}$ Ibid., 373.
} 


\section{CHAPTER 6 \\ FROM GOTHS TO BYZANTINES: ITALY AND ISTRIA DURING THE SIXTH CENTURY}

The terms late antique and early Byzantine are often used in tandem to describe the historical context of the fifth and sixth century Mediterranean. However, care should be taken to use these terms accurately. As demonstrated in chapters 4 and 5 , late antiquity is used to describe the political, religious, and artistic contexts of the Mediterranean world during the fourth and fifth centuries. In this chapter, the term early Byzantine will be used to describe the period of the sixth century beginning with the reign of Justinian. This is due, in part, to the creation of an identity which contemporaries would have called Romaioi, but what modern scholars call "Byzantine," that stemmed from the political and religious policies put in place by Justinian. ${ }^{217}$ In addition, the spread of this identity is closely tied to Justinian's successful military campaigns against the Vandals of North Africa and the Ostrogoths of Italy.

\section{Theoderic and Ostrogothic Italy}

The arrival of Germanic-speaking tribes in the Italian peninsula during the fifth century, led to the continued dissolution of the western Roman Empire, with the

\footnotetext{
${ }^{217}$ For a full discussion of the issues surrounding the use of these two terms see the chapter titled, "The World a City: Romans of the East" in Anthony Kaldellis, Hellenism in Byzantium: The Transformations of Greek Identity and the Reception of the Classical Tradition (Cambridge: Cambridge University Press, 2007): 42-119.
} 
exception of the imperial city of Ravenna. ${ }^{218}$ The resistance of Ravenna to these "Gothic invasions" can be attributed to a variety of factors ranging from natural topography to the Gothic preoccupation with the Hunnic incursions. The deaths of Attila the Hun in 453 and the western Roman emperor Valentinian III in 454 allowed the Ostrogoths (a group of Goths who lived, primarily, in the eastern portions of the Empire) to realign their political priorities. ${ }^{219}$ As a result of the death of Valentinian III, and after a series of power struggles, authority fell into the hands of the Germanic magister militum, Ricimer, who died in $472 .^{220}$ By 474 the emperor Nepos was forced to retreat to the Dalmatian coast by the unpopular leader of the Ostrogothic military, Orestes. ${ }^{221}$ From Dalmatia, Nepos bestowed the title of Augustus upon his son, Romulus, who came to be known as the last western Roman emperor. Moorhead discusses the relatively benign response to the dissolution of the western Roman imperial throne and notes that the historical impact was more noticeable in Constantinople than it was in Rome. ${ }^{222}$ Whatever the response, the "collapse" led to the installation of the Ostrogothic King Odoacer, who controlled Italy by $476 .^{223}$

According to sixth-century sources, the reign of Odoacer was incredibly unpopular. $^{224}$ These sources, however, were written under the patronage of Odoacer's

\footnotetext{
${ }^{218}$ For a brief overview of this period see Christie (2006): 32-34

219 John Moorhead, Theoderic in Italy (Oxford: Clarendon Press, 1992): 6-7.

220 Ibid., 7.

221 Ibid., 7.

${ }^{222}$ For an archaeoethnographic survey of the response see Federico Marazzi, "The Last Rome: From the End of the Fifth to the End of the Sixth Century," The Ostrogoths from the Migration Period to the Sixth Century: An Ethnographic Perspective, ed. S.J. Barnish and F. Marazzi (Woodbridge, The Boydell Press, 2007): 281-285; and Moorhead (1992): 8-9 and 35.

223 Ibid., 7.

${ }^{224}$ Cassiodorus, Ennodius, Jordanes, and Procopius discuss the decay of society during Odoacer's reign. See ibid., 28-29, notes 113-115.
} 
successor, Theoderic and, therefore, should not be taken as historically accurate. ${ }^{225}$

Contemporaries of Odoacer would have had few reasons to complain, especially Roman senators, who benefitted from his restoration of their seats in the Flavian Amphitheater, for example. ${ }^{226}$ In addition, Odoacer secured the annexation of Dalmatia and removed the Vandals from Sicily. ${ }^{227}$ By the end of the fifth century, Italy had become increasingly isolated, politically and economically, from the eastern Roman Empire, a development that led to the intervention of Constantinople with the help of another Ostrogoth, named Theoderic. $^{228}$

As a result of an Ostrogothic uprising in 461, led by the brothers Thiudimir and Vidimir, against the imperial territory of Illyricum, Thiudimir's seven or eight year old son, Theoderic, was taken to Constantinople as a hostage. ${ }^{229}$ Theoderic lived in the court of Leo I at Constantinople for ten years and received a classical education that befitted a member of the imperial family. ${ }^{230}$ When Theoderic was eighteen years old, he was allowed to leave the court and subsequently returned to his people who, by this time, had become deeply fractured from constant internal conflict. Upon his father's death in 474, Theoderic was named king of his faction of Ostrogoths. ${ }^{231}$ Theoderic sought economic support from the new emperor, Zeno, who instead sent unwanted gifts and marriage proposals. ${ }^{232}$ Theoderic responded angrily and vowed to plunder imperial land. ${ }^{233}$ By 476, however, the two had come to terms, which led Zeno to bestow the Gothic ruler with

\footnotetext{
${ }^{225}$ Sabine G. MacCormack discusses the propagandistic quality of these sources. See her, Art and Ceremony in Late Antiquity (Berkley: University of California Press, 1981): 229-235.

${ }^{226}$ Moorhead (1992): 9.

${ }^{227}$ Ibid., 9.

${ }^{228}$ Ibid., 10.

${ }^{229}$ Ibid., 13; and Deliyannis (2010): 109.

${ }^{230}$ Moorhead (1992): 14; Deliyannis (2010): 19

${ }^{231}$ Moorhead (1992): 15

${ }^{232}$ Ibid., 16

${ }^{233}$ Ibid., 16.
} 
the title magister militum praesentalis and soon he was known as the emperor's son-atarms. ${ }^{234}$ In 484 Theoderic was named Consul of the Eastern Empire and four years later he led a group of Ostrogothic soldiers into Italy in order to remove Odoacer. ${ }^{235}$ Whether he initiated this campaign of his own accord, or upon the instigation of Zeno, by 490 Theoderic had control of the majority of Italy. ${ }^{236}$

That same year Theoderic laid siege to Ravenna where Odoacer had taken refuge, presumably on the assumption that the city could not be breached due to its natural defenses. Theoderic used these natural defenses against the city and surrounded its protective marshes, effectively starving the ruler and his people into submission. ${ }^{237}$ In a desperate attempt for peace, Odoacer, an Arian Christian, turned to the city's Orthodox bishop, John, as a mediator. In February 493 the bishop "opened the gates and came out with crosses, thuribles, and gospels, and prostrated himself before Theoderic.. ${ }^{238}$ By March $5^{\text {th }}$, Theoderic and Odoacer had reached an accord that allowed for joint leadership of Italy. ${ }^{239}$ Security was short-lived, however, and ten days later, on March $15^{\text {th }}$ at a celebratory banquet, Theoderic murdered his co-ruler and claimed himself Rex, King of Italy. $^{240}$

The ruthlessness of Theoderic's meteoric rise to power was tempered with an overwhelming sense of tolerance. Throughout the thirty years of his reign, Theoderic ruled from his capital at Ravenna, a city that had been founded as a Roman imperial

\footnotetext{
${ }^{234}$ Moorhead (1992): 16; Deliyannis (2010): 109.

${ }^{235}$ Moorhead (1992): 16-17; Deliyannis (2010): 109.

${ }^{236}$ According to Moorhead, Theoderic acted upon the request of emperor Zeno, who wanted to punish Odoacer for his support of the rebel patrician, Illus. See Moorhead (1992): 17. Deliyannis is more cautious and suggests that Theoderic was acting on his own strategic impulses. See Deliyannis (2010): 109.

${ }^{237}$ Moorhead (1992): 25; Deliyannis (2010): 109.

${ }^{238}$ Moorhead (1992): 25.

${ }^{239}$ Ibid., 25; Deliyannis (2010): 109.

${ }^{240}$ Moorhead (1992): 25; Deliyannis (2010): 109.
} 
capital. Theoderic was acutely aware of the Ostrogothic minority, amounting to approximately 5-10\% of Ravenna's total population and, therefore, ruled accordingly. ${ }^{241}$ He was known for his staunch support of the imperial senate in Rome and bestowed upon the ancient city a series of renovations that included the city's walls, sewers, palaces, Curia, Theater of Pompey, aqueducts, and granaries and championed himself as a restorer of the Roman infrastructure. ${ }^{242}$ Procopius, who wrote during the reign of Justinian, discussed Theoderic's popularity and his refusal to call himself emperor, even though he ruled as one. ${ }^{243}$ This refusal, along with the traditional Roman governmental style of his administration, allowed him to be seen as a powerful subordinate to the emperor in Constantinople.

Theoderic sought to place himself in a long line of strong rulers, specifically of Roman birth. While he did not deny his Gothic origins, he sought to gain political authority through the emulation and reassertion of the Roman imperial past. ${ }^{244}$ This strategy, also taken by emperors and bishops of the fourth and fifth centuries, became even more politically expedient for Theoderic because of his non-Roman origins. Moreover, Theoderic's Arian beliefs conflicted with Rome and Ravenna's Orthodox majority. Therefore, when Theoderic embarked on his building campaign, he looked to traditional Orthodox forms as prototypes for his Arian structures. This, paired with a vibrant literary culture in Ravenna, points to an "Ostrogothic Renaissance" that also included a deliberately classicizing building program. ${ }^{245}$

\footnotetext{
${ }^{241}$ Deliyannis (2010): 110.

${ }^{242}$ Moorhead (1992): 61; Deliyannis (2010): 112.

${ }^{243}$ Deliyannis (2010): 110.

${ }^{244}$ Ibid., 111.

${ }^{245}$ Mark J. Johnson, “Toward a History of Theoderic's Building Program," Dumbarton Oaks Papers 42 (1988): 76; Deliyannis (2010): 111-112.
} 
Theoderic's building program included an equal amount of sacred and secular construction that consistently recalled earlier basilica-style churches, centrally-planned baptisteries, and the sprawling imperial palace complexes of Rome, Ravenna, and Constantinople. ${ }^{246}$ Recent excavations of Ravenna's imperial palace complex reveal sixth-century renovations indicating that Theoderic built onto the fifth-century complex, an act similar to the ongoing construction of the Great Palace at Constantinople. ${ }^{247}$ Based on these excavations, the notion that Ostrogothic Ravenna was segregated into Gothic and Roman areas has been refuted. ${ }^{248}$ The Arian Episcopal complex was located outside of the so-called Gothic zone (an area purported to encompass the northeastern part of the city), as were Arian churches found in Ravenna and Classe. ${ }^{249}$

The ability for Arian and Orthodox churches to coexist peacefully illustrates Theoderic's ability to govern adherents to both sides of the Christological debate with an even hand. This practice is also manifest in Theoderic's use of the basilica-style for the churches of Santo Spirito (the Arian Cathedral) and Sant'Apollinare Nuovo (originally dedicated to the Savior). ${ }^{250}$ In addition, the Arian Baptistery, located to the west of Santo Spirito, is so remarkably similar to the Neonian (Orthodox) Baptistery that some scholars have suggested that it was deliberately copied after it. ${ }^{251}$ The similarities between the architecture and decorative programs of these churches also reveal the close relationship

\footnotetext{
${ }^{246}$ Johnson (1988): 82; Deliyannis (2010): 115.

${ }^{247}$ For the Ravennate palace, see Andrea Augenti, "Archeologia e topografia a Ravenna: il Palazzo di Teodorico e la Moneta Aurea," Archeologia Medievale 31 (2005): 13-16. For the Great Palace of Constantinople see Jonathan Bardill, "The Great Palace of the Byzantine emperors and the Walker Trust excavations," Journal of Roman Archaeology 12:1 (1999): 216-230.

${ }^{248}$ Deliyannis (2010): 116.

${ }^{249}$ Ibid., 116.

${ }^{250}$ For a discussion on Santo Spirito see Deliyannis (2010): 174-177; for Sant'Apollinare Nuovo see Ibid., 146-174.

${ }^{251}$ This argument is strengthened by similarities in the dome mosaics. For a full discussion, see Deliyannis (2010): 177-187.
} 
between the Arian and Orthodox churches. While the two differed theologically, Theoderic was aware that, if he were to support the election of Orthodox bishops, he would, in turn, be able to appoint his own Arian clergy. ${ }^{252}$ This is yet another example of Theoderic's adroit leadership skills.

While Theoderic's success was closely tied to his ability to connect himself to the imperial past, his only shortcoming was his failure to produce a male heir. Therefore, succession was dependent on the success of his daughter's husband, Eutharic. In 519, to great fanfare, Theoderic celebrated the consulship of Eutharic who soon became son-atarms to the Emperor Justin, thus ensuring him as a successor. ${ }^{253}$ Unfortunately for Theoderic, Eutharic died in 522. ${ }^{254}$ This paved the way for Amalasuintha's son, Athalaric, to become heir to the throne. Upon Theoderic's death in 526, Athalaric was named Rex and Amalasuintha became regent. ${ }^{255}$ The untimely death of Athalaric in 534 allowed Amalasuintha to become queen and she chose her cousin, Theodahad, as her coruler. ${ }^{256}$ This proved to be a disastrous decision because within a year Theodahad shipped her off to the island of Volsena (modern Martana Island) assumed full control. ${ }^{257}$ While imprisoned, Amalasuintha sent a letter to the new emperor, Justinian, and pleaded for his intervention. ${ }^{258}$ By the end of 535 Amalasuintha had been killed, which caused Justinian to send his most successful general, Belisarius, to reclaim the Italian peninsula. ${ }^{259}$

\footnotetext{
${ }^{252}$ Christie (2006): 137-140; Deliyannis (2010): 188.

${ }^{253}$ Moorhead (1992): 212; Deliyannis (2010): 114.

${ }^{254}$ Deliyannis (2010): 114.

${ }^{255}$ Moorhead (1992): 254-255; Deliyannis (2010): 136.

${ }^{256}$ Moorhead (1992): 255; Deliyannis (2010): 137.

${ }^{257}$ Moorhead (1992): 255; Deliyannis (2010): 137.

${ }^{258}$ Deliyannis (2010): 137.

${ }^{259}$ Moorhead (1992): 255; Deliyannis (2010): 137.
} 


\section{Justinian and Early Byzantine Italy}

The political transition that occurred after the onset of the Gothic Wars signaled the advent of the early Byzantine period. The change in terminology stems from the rapid accession of the emperor Justinian through his uncle and imperial predecessor, Justin I, and the transformation of the Roman Empire into a thoroughly Christian state. ${ }^{260}$ According to Maas, the reign of Justinian "was the chief catalyst in forging the Byzantine Alloy, a world in which Christian, Roman, Greek, and many local elements fused to create a new medieval civilization within the imperial borders." ${ }^{261}$ Of course, the emperor would not have seen his reign as one that ushered in a new era; to Justinian he was simply piecing back together "a very old, but unorganized empire.,"262

In the early years of Justinian's reign, his top priority was to rein in the chaos that had overtaken the Empire. He began with an overhaul of the Roman legal system and, in 529, with the help of a specially appointed group of ten commissioners, produced the Codex Justinianus (the Code of Justinian). ${ }^{263}$ This newly codified legal system placed the corpus of Roman law "within an explicitly Christian framework."264 Next, Justinian entered the military arena and sent a contingent of Byzantine troops to the eastern border of Sasanian Persia. By 532 he pulled these troops from the eastern provinces and realigned his focus, for a brief time, on the Nika Riots of Constantinople, which were

\footnotetext{
${ }^{260}$ Michael Mass, "Roman Questions, Byzantine Answers: Contours of the Age of Justinian," The Cambridge Companion to The Age of Justinian ed. Michael Mass (Cambridge: Cambridge University Press, 2004): 4.

${ }^{261}$ Maas (2004): 4.

${ }^{262}$ Ibid., 4.

${ }^{263}$ For a detailed discussion of the Codex Justinianus and Justinian's other legal changes, see Caroline Humfress, "Law and Legal Practice in the Age of Justinian," The Cambridge Companion to The Age of Justinian ed. Michael Mass (Cambridge: Cambridge University Press, 2004): 161-184.

${ }^{264}$ Ibid., 162.
} 
followed by the overthrow of the Vandal and Gothic kingdoms of North Africa and Italy, respectively. $^{265}$

Justinian's decision to attack Vandal North Africa and Gothic Italy was, initially, unpopular with his generals. Procopius writes, "when he revealed to his officials that he was assembling an army against the Vandals...most of them were unhappy about it and regarded it as a mistake."266 Justinian explained to his advisors that the invasions were necessary in order to release North Africa from the plight of Arian Christianity. After the death of Amalasuintha, an Arian who had close ties to the Orthodox court, Justinian saw another opportunity to emancipate a former province from the grip of Arianism. In 535 Justinian sent Belisarius to Ostrogothic Sicily. The battle was quick and soon Belisarius and the Byzantine army began to march north through Campania to Rome. The success in Sicily was not matched in other parts of Italy and it took approximately twenty years for Belisarius and his armies to completely defeat the Ostrogothic forces.

Ravenna, however, quickly ceded to Byzantine rule in 540. This was due, in part, to the city's large Orthodox population, which must have seen the imperial armies as liberators. Ostrogothic Ravenna had not been overtly oppressive to the Orthodox majority, a fact illustrated by the rise in political authority of the Orthodox bishops. ${ }^{267}$ However, the religious freedom that could be gained by the dissolution of the Arian administration would have, certainly, been attractive to them. Sometime before 533, the political influence of Ravenna's Orthodox bishops grew exponentially and Justinian was

\footnotetext{
${ }^{265}$ For an overview of Justinian's military engagements see A.D. Lee, "The Empire at War," The Cambridge Companion to The Age of Justinian ed. Michael Mass (Cambridge: Cambridge University Press, 2004): 113-133.

${ }^{266}$ Lee (2004): 116.

${ }^{267}$ Maas (2004): 107; and Wataghin (2006): 287-309.
} 
persuaded to elevate their Episcopal status to the level of Archbishop, which transformed Ravenna into a provincial capital of the Empire. ${ }^{268}$

While still under Ostrogothic control, Ravennate bishops oversaw the construction of a number of privately funded ecclesiastical monuments, whose architectural plans were closely associated with Constantinopolitan trends. ${ }^{269}$ Many of these new Orthodox monuments were built during the episcopate of Ecclesius (522-532), who served during the height of Ostrogothic power and in the wake of Theoderic's death. Ecclesius was one of the clerics who had been, with Pope John I, sent by Theoderic to Constantinople in 525 to protest against Justinian's predecessor, Justin, in an effort to bring an end to the persecution of Arian Christians. ${ }^{270}$ While in the imperial capital, Ecclesius would have come into direct contact with Constantinopolitan architectural trends that varied greatly from the traditional basilica-style and central-plan churches of Italy. These eastern trends were lavishly illustrated in the Church of St. Polyeuktos, a monument built by the Byzantine noblewoman, Anicia Juliana. The date of this church, between 524-527, places its construction during Ecclesius' visit. Excavations of this church revealed that it was based on a basilica-style plan that was covered either by a dome or a timber-trussed roof. ${ }^{271}$ The use of semi-circular exedrae, which separated the nave from the side aisles, combined with the expensive decorative program, created a thoroughly innovative and new style of sacred space. ${ }^{272}$ (fig. 63) The nature of the

\footnotetext{
${ }^{268}$ Deliyannis (2010): 201, 210.

${ }^{269}$ Ibid., $199-200$

${ }^{270}$ Ibid., 198.

${ }^{271}$ For the domed-basilica reconstruction, see R. M. Harrison, Excavations at Saraçhane in Istanbul, (Princeton: Princeton University Press, 1986): 410. Jonathan Bardill suggests that the church was covered with a timber-trussed roof, see Jonathan Bardill, "A New Temple for Byzantium: Anicia Juliana, King Solomon, and the Gilded Ceiling of the Church of St. Polyeuktos in Constantinople." in Social and Political Life in Late Antiquity ed. William Bowden, et al., (Leiden: Brill, 2006): 339-370.

${ }^{272}$ Ibid., 364.
} 
decoration and the complexity of the architectural plan befitted the monument and its patron who saw herself as a rival to the imperial throne and sought to build the most lavish church in Constantinople.

Upon his return to Ravenna, Ecclesius sanctioned the construction of several churches that were funded by the wealthy banker, Julianus Argentarius. ${ }^{273}$ Many of these monuments were built on land owned by the bishop and located in the northwestern part of the city. ${ }^{274}$ The revolutionary architectural plans of these churches and their lavish interior decoration point to Ecclesius' journey to the imperial capital. ${ }^{275}$ A detailed discussion of these monuments and their distinctly Byzantine stuccowork motifs will be discussed in the following chapter.

\section{Early Byzantine Ravenna and the Istrian Peninsula}

While the focus of Justinian's military campaigns was concentrated in Italy, his successful overthrow of Ravenna's Ostrogothic leadership had an impact on the cities of the Istrian peninsula. ${ }^{276}$ Located on the western shore of the Adriatic Sea, Istria is the site of numerous sixth-century ecclesiastical foundations. (fig. 64) During the sixth century, the cities of Poreč (Parentium, Parenzo) and Pula (Pola) contained the majority of these buildings. The theological and architectural connections between the Istrian cities and Ravenna are many and stem from Justinian's decision to make Ravenna an

\footnotetext{
${ }^{273}$ For a discussion of these churches see Deliyannis (2010): 219-275.

274 Ibid., 221.

275 Ibid., 221-222.

${ }^{276}$ Rajko Bratož, "The Development of the Early Christian Research in Slovenia and Istria Between 1976 NS 1986," Actes du XIe Congrès International d'Archéologie Chrétienne (1989): 2345-2388; and Ibid., "Cristianesimo in Istria. Una sintesi e alcune riflessioni (con particolare riguardo allo sviluppo dell'organizzazione ecclesiastica)," Il Christianesimo in Istria fra tarda antichità e alto medioevo: Novita e riflessioni: Atti delle giornata tematica dei Seminari di Archeologia Cristiana (Roma-8 marzo 2007), ed. Emilo Marin and Danilo Mazzoleni (Città del Vaticano: Pontifico Istituto di Archeologia Cristiana, 2009): 9-46.
} 
Archiepiscopal see. As a result, Ravennate bishops no longer had to emerge from the local clergy. ${ }^{277}$

One of the most influential of the foreign-born archbishops was Maximian (546-

557). Agnellus writes, "He was not from this flock, but an alien sheep from the church of Pula, ordained as a deacon by its bishop."278 Agnellus continues with the consecration of Maximian in 546:

"It happened at that time that Victor, bishop of this city of Ravenna, died, and the citizens of Ravenna, the priests together with people, went to the emperor, seeking the pallium for their candidate. After hearing them, the emperor ordered the petitioners to wait. Having considered the matter, he ordered blessed Maximian, the deacon from Pula, to be consecrated..., 279

Upon entering Ravenna, Maximian, like his predecessors, embarked on an extensive building program. ${ }^{280}$ Unfortunately, his ex novo foundations no longer survive, but we are told by Agnellus that he constructed a basilica-style church dedicated to Santa Maria Formosa in the town of Pula. ${ }^{281}$ The Episcopal palace complex and cathedral of Eufrasius (c. mid $6^{\text {th }}$-century), found in Poreč, illustrates yet another Ravennate connection, albeit based on stylistic grounds. ${ }^{282}$

The ties connecting Ravenna and Istria during the Justinianic period reveal a desire, on the part of provincial towns, to incorporate imperial architectural trends. These trends traveled back and forth between Italy and Constantinople as a result of the military campaigns of Justinian and his generals. In addition, the appointment of bishops, directly

\footnotetext{
277 Deliyannis (2010): 210.

278 Deliyannis (2004): 184.

279 Ibid., 185.

${ }^{280}$ Ibid., 256-257.

${ }^{281}$ Ibid., 189. For a discussion of the remains of this church, see Gillian Mackie, Early Christian Chapels in the West: Decoration, Function, and Patronage (Toronto: University of Toronto Press, 2003): 47-51.

${ }^{282}$ Ann Terry and Henry Maguire, Dynamic Splendor: The Wall Mosaics in the Cathedral of Eufrasius at Poreč (University Park, The Pennsylvania State University Press, 2007): 59-69.
} 
from the capital allowed Constantinopolitan influence to permeate not only Ravenna, but the smaller towns of Italy and Istria as well. 


\section{CHAPTER 7}

\section{EARLY BYZANTINE STUCCOWORK FROM THE SIXTH CENTURY IN ITALY AND ISTRIA}

During the sixth century, the inclusion of human figures in stuccowork programs was replaced by an increased interest in the installation of geometric, vegetal, and floral stucco elements. Moreover, stuccowork in the sixth century appears to have been relegated to less-conspicuous parts of ecclesiastical interiors. Even with this demotion of placement, stuccowork programs of this period continued to be installed in monumental architecture. The decorative quality of this stuccowork was juxtaposed with elaborate figural mosaic programs. The chronology of the shift in decorative trends is closely tied to the historical framework of the sixth century, which bore witness to Italy's transformation into a Byzantine province. In this chapter, the close political and religious connections between Italy and Constantinople will be explored in terms of architectural decoration, as well as their influence on the decorative programs of the Istrian peninsula.

\section{Santa Maria in Cosmedin, Rome}

Stuccowork in early Byzantine Rome is limited to the Church of Santa Maria in Cosmedin, which is located at the foot of the Aventine and Palatine Hills and on the banks of the Tiber River. The basilica-style church consists of several building phases, 
the earliest of which dates to the late sixth century. ${ }^{283}$ Since the fourth century, the site had been associated, with the distribution of the empire's grain supply, known as the statio annonae. ${ }^{284}$ Sometime after the Byzantine reconquest of the city in 536, a food distribution center (a diaconia) was built to accommodate the city's population. The sixth-century diaconia was enlarged into a basilica-style church in the eighth-century for the city's Greek-speaking population who lived in the quarter known as Cosmedin, a Greek word that means "embellished."285 Although Cosmedin was a later appellation, the area had been known in the sixth-century as the schola graeca, a term that was applied to "foreign communities and their compounds in early medieval Rome."286 Therefore, it is plausible that there was a Byzantine connection to the building programs of both the sixth and eighth centuries at the site.

The only surviving elements of the sixth-century building phase are located in the western entryway of the loggia into the church and the western portion of the nave's northern wall. (figs. 65 and 66) The extant decoration from this phase is found on two of the six soffits of the loggia. The fragmentary stucco remains of these two soffits include stylized vegetal motifs of grain, appropriate for the site, and acanthus leaves emerging from wicker baskets. ${ }^{287}$ (figs. 67 and 68). Pasquini asserts that there is no indication of the use of molds and thereby posits that the stuccoes were installed in a free-form manner. ${ }^{288}$ She makes a stylistic comparison to the stuccowork of sixth-century Ravenna,

\footnotetext{
${ }^{283}$ Krautheimer (1937-1977): v. II 306-307; and Ibid., Rome: Profile of a City, 312-1308, (Princeton: Princeton University Press, 1983), 77.

${ }^{284}$ Krautheimer (1983): 77; Pasquini (2002): 72.

285 Krautheimer (1983): 77

${ }^{286}$ Ibid., 78.

${ }^{287}$ Pasquini (2002): 72.

${ }^{288}$ Ibid., 73.
} 
where similarly stylized vegetal motifs are found. ${ }^{289}$ She also proposes a stylistic connection to Byzantine styles because of the presence of Greeks at the site during the period of construction. ${ }^{290}$ Pasquini's hypotheses are strengthened by an analysis of sixthcentury Ravennate stuccowork, which also displays conspicuous connections to Byzantine styles, specifically from Constantinople.

\section{San Vitale, Ravenna}

The most extensive sixth century stuccowork program in Ravenna is found in the Church of San Vitale. Initial construction of the church dates to the episcopate of Ecclesius, probably in 527..$^{291}$ The church's dedication took place in 547, during the episcopate of Maximian, who renovated the imperial panel mosaics in order to include himself, prominently displayed alongside Justinian and his officers. ${ }^{292}$ The church is based on a double-shell octagonal plan, which is rare on the Italian peninsula, ${ }^{293}$ and points to eastern influences. However, Deliyannis notes that such comparisons should be made cautiously and must take into account the chronology of its founder, Ecclesius, and his journey to the imperial capital. ${ }^{294}$

\footnotetext{
${ }^{289}$ Pasquini (2002): 73.

${ }^{290}$ Ibid., 73.

${ }^{291}$ Deliyannis (2010): 226.

${ }^{292}$ For this interpretation see Irina Andreescu-Treadgold and Warren Treadgold, "Procopius and the Imperial Panels of S. Vitale," Art Bulletin 79, (1997): 708-723.

${ }^{293}$ For an architectural history, see F. W. Deichmann, Ravenna, Hauptstadt des spätantiken Abendlandes (Wiesbaden: F. Steiner, 1976): 34-205; and Patrizia Angiolini, La Basilica di San Vitale a Ravenna (Modena: F.C. Panini, 1997).

${ }^{294}$ Deliyannis (2010): 226; Deichmann proposes that the church was influenced by the Church of S.S. Sergius and Bacchus (526-536) in Constantinople. For this see Deichmann (1976): 83. For an additional note on octagonal churches, see Cyril Mango, "The Church of Saints Sergius and Bacchus at Constantinople and the Alleged Tradition of Octagonal Palatine Churches," Jahrbuch der österreichischen Byzantinistik 21 (1972): 189-193.
} 
At the request of Theoderic, Ecclesius had been sent to Constantinople in 525, along with Pope John I in order to protest Emperor Justin’s Arian persecutions. ${ }^{295}$ After his return in 527, Ecclesius initiated the construction of a church, dedicated to St. Vitalis, which was funded by Julianus Argentarius and cost 26,000 gold solidi. ${ }^{296}$ The church was constructed from newly manufactured brick and was built on a plot of Episcopal property, within 40-50 meters from Santa Croce (after 425) and Santa Maria Maggiore (526-532). ${ }^{297}$ (fig. 69) As discussed in the previous chapter, Ecclesius would have encountered a variety of buildings in the imperial capital during his stay, including Anicia Juliana's massive church, St. Polyeuktos (524-527). While the architectural plan of San Vitale is significantly different than that of St. Polyeuktos, the decorative programs are quite similar. While excavations at St. Polyeuktos did not reveal traces of stuccowork, a large amount of finely carved marble sculpture was uncovered. ${ }^{298}$ The fragments indicated that the interior of St. Polyeuktos was filled with peacocks, scallop shells, vine scrolls, jewel-inlaid columns topped with elaborate basket-capitals, and a lengthy dedicatory poem, all carved from Proconessian marble. (fig. 70)

With the exception of a dedicatory poem, similar elements decorated the interior of Ecclesius' San Vitale. However, unlike St. Polyeuktos, the use of marble was limited to non-figural sculptural elements, opus sectile, and marble revetment. (fig. 71) The marble used for the revetment included Proconessian and cipollino rosso, which were

\footnotetext{
${ }^{295}$ Deliyannis (2010): 198.

${ }^{296}$ For Agnellus' account, see Deliyannis (2004): 171-177. In addition, San Vitale was just one of several Orthodox churches built during the waning years of Ostrogothic rule. These churches, funded by Julianus Argentarius, included Santa Maria Maggiore, Sant'Apollinare in Classe, and San Michele in Afrisco. For a detailed discussion of these churches, see Deliyannis (2010): 200 and 221-274.

${ }^{297}$ Deliyannis (2010): 222-223.

${ }^{298}$ Harrison (1986): 117-181.
} 
imported from the islands of Proconessos and Iasos, respectively. ${ }^{299}$ In total, the marble sculpture, opus sectile, and revetment, are approximated to weigh 188 metric tons, which is the largest amount of marble in any Ravennate church. ${ }^{300}$ The conspicuous lack of three-dimensional figural elements is a hallmark of sixth-century decorative programs. Any figural elements present in San Vitale, or any early Byzantine church in Ravenna, appear in the expansive mosaic programs that covered the upper portions of walls and vaults. $^{301}$ (fig. 72) This is illustrated by the figural mosaic programs found in the Archiepiscopal Chapel and the churches of San Michele in Afrisco and Sant'Apollinare in Classe. ${ }^{302}$

While every surface was covered with the most expensive materials, the designers of San Vitale continued the tradition of decorative stuccowork and installed programs on surfaces that were not already covered by either marble or mosaic. ${ }^{303}$ Upon close physical examination of the church's stuccowork, it is clear that the programs were installed without the use of molds and were, instead, applied in a free-form manner. ${ }^{304}$

\footnotetext{
${ }^{299}$ Deliyannis (2010): 234.

${ }^{300}$ For a full discussion of the acquisition of marble in the sixth-century, see James G. Harper, "The Provisioning of Marble for the Sixth-Century Churches of Ravenna: A Reconstructive Analysis," Pratum Romanum: Richard Krautheimer zum 100. Gerburtstag, (Wiesbaden, 1997): 131-148.

${ }^{301}$ For an overview of these mosaics see Deliyannis (2010): 236-250; for interpretations of these see Irina Andreescu-Treadgold, "The Mosaic Workshop at San Vitale," Mosaici a S. Vitale e altri restauri: il restauro in situ di mosaici parietali. Atti del Convegno nazionale sul restauro in situ di mosaici parietali: Ravenna 1-3 ottobre 1990, ed. Anna Maria Iannucci, (1992): 31-41; Ibid., "The Emperor's New Crown and St. Vitalis' New Clothes," Corso di cultura sull'arte Ravennate e Bizantine 41, (1994): 149-186; and Andreescu-Treadgold (1997): 708-723.

${ }^{302}$ For an overview of the decorative program of the Archiepiscopal Chapel, see Deliyannis (2010): 188196). For a discussion of the reconstructed apse mosaics of San Michele in Afrisco that are on display at the Staatliche Museen zu Berlin, see Deliyannis (2010): 250-254; and Irina Andreescu-Treadgold, "The Wall Mosaics of San Michele in Africisco, Ravenna, Rediscovered," Corso di cultura sull'arte Ravennate e Bizantine 37 (1990): 13-57. For an overview of the mosaics of Sant'Apollinare in Classe, see Deliyannis (2010): 265-274.

${ }^{303}$ Deliyannis (2010): 235; Pasquini (2002): 40-50.

${ }^{304}$ Pasquini (2002): 40-41.
} 
This is remarkable given the stuccowork's highly organized compositions, which would have been more quickly and consistently applied with the use of molds.

The surviving stuccowork of San Vitale is found in several locations. The first, and most extensive, is found on the walls and vaults of the southern triangular vestibule that connects the narthex to the ambulatory. (fig. 73) The remarkable state of preservation is due to the renovation of the vestibule, which blocked off the arcade and protected the stucco from further deterioration. ${ }^{305}$ The stuccoes are entirely non-figural and consist of vinescrolls on the walls, and field of identical grape leaves in a tightly organized grid, which are found in a barrel-vaulted section of the vestibule. (fig. 74) Similar to the mosaics of the presbytery, each of the stuccowork sections is surrounded by a framing device. These frames render the vegetal motifs in a more stylized fashion than their organic counterparts in the tombs of ancient Rome. This is further emphasized by the inclusion of an arbitrary grid system that contains the field of grape leaves. ${ }^{306}$ In addition, these framing devices, which are present throughout the church, work together to unify the variety of materials used in the decorative program. ${ }^{307}$ Ernst Kitzinger also suggests that these devices were used as classicizing elements framing non-classical styles, as illustrated in the shallow depth of field and the emphasis on linear elements found in the Old Testament scenes of the presbytery mosaics. ${ }^{308}$ (fig. 75)

A second group of stuccoes is found on the soffits of the triple arcade that separates the northern triangular vestibule from the ambulatory. (fig. 76) The central

\footnotetext{
305 Shapley (1923): 22.

306 This type of grid system was common in the floor mosaics of the early Byzantine period, throughout the empire. For the development of this motif see, Anna Gonosová, "The Formation and Sources of Early Byzantine Floral Semis and Floral Diaper Patterns Reexamined," Dumbarton Oaks Papers 41 (1987): $227-$ 237.

${ }^{307}$ For a full discussion of these framing devices, see Kitzinger (1997): 81-98.

${ }^{308}$ Ibid., 84.
} 
soffit is filled with symmetrical vinescrolls emerging from cornucopias. Within the vinescrolls, grape leaves, rosettes, and birds fill the highly organized composition. (fig. 77) The two soffits flanking the central arcade contain similar motifs, although without the cornucopias and birds. (figs. 78 and 79) The soffits also have framing devices that are consistent in style, albeit simplified, with the frames throughout the church.

The third group of stuccoes is found in the soffits of the two triforia flanking the presbytery in the eastern end of the church. They are relatively well preserved, which is due, in part, to the protection they received after the triforia were walled up. It was only during the eighteenth century that the medieval walls were removed and revealed the stucco that can be seen today. ${ }^{309}$ There are four distinct grid-patterns that appear on these soffits, all of which are geometric and contain stylized floral elements. ${ }^{310}$ (figs. 80-81) The central soffit of the northern triforium contains a field of rosettes, each enclosed by an octagonal frame, which creates a repeating pattern of flowers and geometric elements. This soffit is flanked by two identical soffits that contain patterns of four-petalled flowers, each enclosed by a circle, which creates another repeating floral and geometric pattern. The central soffit of the southern triforium contains a field of four-petalled flowers surrounded by notched circles. This soffit is flanked by identical soffits within similar four-petalled flowers surrounded by circles. Egg-and-dart and acanthusembellished framing devices are included along the edges of the triforia's soffits, which correspond to the frames found elsewhere in the structure.

San Vitale's stuccowork should be viewed as a three-dimensional version of twodimensional mosaics, which composed the majority of the decorative program. When

\footnotetext{
${ }^{309}$ Shapley (1923): 22.

${ }^{310}$ Ibid., 25-27.
} 
taken as a whole, the decorative program reflects the Eucharist through the inclusion of vinescrolls and grape leaves, which reference the wine used during the Eucharistic liturgy. ${ }^{311}$ Additionally, scholars have interpreted the stuccoes as representative of the terrestrial world. ${ }^{312}$ This interpretation is bolstered by the free-form application of the floral and geometric motifs and can be seen as deliberately classicizing. ${ }^{313}$ However, another interpretation takes into consideration the stylization of the vegetal motifs, which places an emphasis on linear elements instead of the mottling of figures through the careful use of shadows. The emphasis on symmetry and pattern connects these stuccoes to eastern sources, specifically from Sasanian Persia. ${ }^{314}$ The popularity of Persian textiles during the sixth century led to the incorporation of similar styles and motifs in the architectural decoration of early Byzantine churches. ${ }^{315}$ This can be seen in the similarities between the vegetal motifs found in both Sasanian textiles and the decorative marble sculpture from St. Polyeuktos, the Constantinopolitan church that was built shortly before San Vitale. $^{316}$ (figs. 82 and 70) It should be noted that this is not a novel concept for Ravennate architectural decoration. Scholars have, for decades, connected the lavish mosaics of the so-called Mausoleum of Galla Placidia with the textiles of Sasanian Persia. $^{317}$

\footnotetext{
${ }^{311}$ Deliyannis (2010): 248.

${ }^{312}$ The first to offer this interpretation was Shapley (1923): 30-31.

${ }^{313}$ Shapley (1923): 27; Kitzinger (1977): 82-83.

${ }^{314}$ Laura Pasquini, "Elementi orientali-costantinopolitani nelle decorazioni a stucco di S. Vitale," Corso di cultura sull'arte Ravennate e bizantina (1994): 187-206; Pasquini (2002): 42-44.

${ }^{315}$ Anna Gonosová, "Exotic Taste: The Lure of Sasanian Persia," Antioch: The Lost Ancient City ed. Christine Kondoleon (Princeton: Princeton University Press, 2000): 130-133, reprinted in Late Antique and Medieval Art of the Mediterranean World ed. Eva R. Hoffman (Malden: Blackwell Publishing Ltd, 2007): 40-46.

${ }^{316}$ Martin Harrison, A Temple for Byzantium : The Discovery and Excavation of Anicia Juliana's PalaceChurch in Istanbul (Austin: University of Texas, 1989): 122-125; Gonosová (2007): 45; Pasquini (2002): 45-48.

${ }^{317}$ See Shapley (1923): 31.
} 
The style of San Vitale's stuccowork is best described as early Byzantine, which refers to the structure's implicit connection to the imperial capital that had just re-gained control of the Italian peninsula. As described in the previous chapter, the fall of Ostrogothic Ravenna in 540 paved the way for a fully formed Byzantine city, which was filled with structures that recalled Constantinopolitan trends. Moreover, these trends, which included the stylization of vegetal motifs and an emphasis on geometry and pattern, extended beyond major Episcopal centers and into smaller ecclesiastical centers along the Adriatic coast.

\section{Santa Maria delle Grazie, Grado}

Fragments of sixth-century stucco are extant in the Church of Santa Maria delle Grazie. This small basilica-style church, built during the episcopate of Elias (571-586), is located in Grado, a town neighboring the ecclesiastical center at Aquileia. ${ }^{318}$

Fragmentary stucco cornices were discovered during renovations undertaken in $1920 .{ }^{319}$ The fragments are found on the lower parts of a window soffit inside the apse and consists of a repeating pattern of stylized acanthus leaves. ${ }^{320}$ (fig. 83) Based on iconographic similarities to Ravennate stucco, scholars date these fragments to the midsixth century. ${ }^{321}$ While there are connections to Ravennate stucco, a difference in style is evident with the emphasis placed on the incised lines on the vegetal motifs. This difference in style does not disconnect it from the free-form quality of San Vitale's

\footnotetext{
${ }^{318}$ Cantino Wataghin (2006): 118; for a discussion of Grado's religious and political context see Sergio Tavano, "Rilievi paleocristiani di Grado," Grado nella storia e nell'arte (1980): 355-371.

${ }^{319}$ Pasquini (2002): 52; for the renovations see P.L. Zovatto, "La Basilica di S. Maria di Grado," Memorie Storiche Forogiulesi XXXIX (1951): 14-33.

${ }^{320}$ Pasquini (2002): 52; Cantino Wataghin (2006): 117-118.

${ }^{321}$ Pasquini (2002): 52-53; it should be noted that at least one scholar argues for a later date. For this see $\mathrm{L}$. Bertacchi, "Architettura e mosaico, Grado, S. Maria delle Grazie," Da Aquileia a Venezia: una mediazione tra l'Europa e l'Oriente dal II secolo a.C. al VI secolo d.C. (Milano: Libri Scheiwiller, 1980): 1980.
} 
stuccoes, as both display an irregularity that cannot be achieved with the use of molds.

Moreover, the similar use of stylized motifs connects the stuccowork of Santa Maria delle

Grazie is related to Justinianic churches found in Poreč, Pula, and Constantinople. ${ }^{322}$

\section{Basilica Eufrasiana and the Episcopal Palace Complex, Poreč}

The stuccowork remains found in the Basilica Eufrasiana and the Episcopal Palace Complex of Poreč provide solid evidence for the stylistic link between Ravennate and Constantinopolitan decorative trends in the early Byzantine period. The Basilica Eufrasiana was built during the episcopacy of Eufrasius (mid-sixth century) on the foundations of an earlier structure and contains the majority of the stuccowork at Poreč. $^{323}$ Because textual evidence for Bishop Eufrasius is scant, the dating of the church relies heavily on comparative examples of architecture and decoration from Ravenna and its environs, as well as from Constantinople.

The decorative program has been thoroughly investigated, with an emphasis placed on the elaborate mosaic program and opus sectile in the church's apse. ${ }^{324}$

Additionally, scholars have provided interpretations of the church's stuccowork program, which has been consistently connected to Ravennate and Constantinopolitan models. ${ }^{325}$ This program was renovated during the 1950s when a bonding agent was applied to

\footnotetext{
${ }^{322}$ Pasquini (2002): 53; Ann Terry, "The Early Christian Sculpture at Grado: A Reconsideration," Gesta 26:2 (1987): 93-112.

${ }^{323}$ Ann Terry, "The Opus Sectile in the Eufrasius Cathedral at Poreč," Dumbarton Oaks Papers 40 (1986): 147; Pasquini (2002): 54.

${ }^{324}$ For the mosaics see Terry and Maguire (2007); Marina Vicelja-Matijašić, "Christological Program in the Apse of Basilica Eufrasiana in Poreč," IKON (2008): 91-102; for the opus sectile see Terry (1986): 147164. Terry also addresses the large amount of original marble sculpture. For this see Ibid., "The Sculpture at the Cathedral of Eufrasius in Poreč," Dumbarton Oaks Papers 42 (1988): 13-64.

325 Šonje (1967): 51-68; Ann Terry, "The Architecture and Architectural Sculpture of the sixth-century Eufrasius Cathedral," PhD diss., University of Illinois at Urbana-Champaign (1984): 280-289; and more recently, Laura Pasquini “Gli stucchi della basilica Eufrasiana di Parenzo," Ocnus, Quaderni della Scuola di Specializzazione in Archeologia IV (1996): 191-201; Pasquini (2002): 54-62; and Matejčić (2006): 125132.
} 
ensure the material's survival. ${ }^{326}$ As the result of an extensive cleaning, traces of the original pigment were revealed, which provides valuable information concerning the original appearance of the sixth-century stuccowork. ${ }^{327}$

The Eufrasiana's stuccowork is found, almost entirely, on the ten soffits of the northern arcade. ${ }^{328}$ Each of the soffits exhibits unique motifs that include a combination of circles, lozenges, octagons, and grids that are filled with a variety of birds, fruits, and vegetal elements. ${ }^{329}$ (figs. 84-93) Additionally, stucco fragments are present in the three soffits of the western windows, which contain similar geometric and vegetal motifs. ${ }^{330}$ (fig. 94) There is also an elaborate stucco cornice in the apse that divides the opus sectile from the mosaic program. The cornice is divided into three sections: the first is a row of dentils; the second is an egg-and-dart motif; and the third is a repeating pattern of stylized acanthus leaves. ${ }^{331}$ (fig. 95) The stuccowork of the Episcopal palace complex, which dates to the same period as the Basilica, is found in the structure's main hall. ${ }^{332}$ The stucco of this hall consists of a fragmentary cornice of swirling grape leaves interspersed with various types of birds. (fig. 96)

The diversity in the motifs of the Eufrasiana's stuccowork was further enhanced by the vivid polychromy of the original installation. While many of the compositions of the stuccoes adhere to geometric patterns, the irregularities reveal a free-form installation that is similar to the stuccoes of San Vitale and Santa Maria delle Grazie. The use of incised lines to emphasize shape also connects the stuccoes in this complex to the

\footnotetext{
${ }^{326}$ Terry (1984): 280.

${ }^{327}$ Ibid., 280.

${ }^{328}$ The stuccowork of the southern arcade was presumably destroyed by an earthquake in 1440 . See Terry (1984): 531, n. 2.

${ }^{329}$ Terry provides a detailed catalogue of these soffits, Terry (1984): 281-286.

${ }^{330}$ Ibid., 286-287.

${ }^{331}$ Ibid., 287.

${ }^{332}$ Ibid., 287; Pasquini (2002): 62; Matejčić (2006): 126-127.
} 
aforementioned examples. The stylization of vegetal and floral motifs, when combined with a geometric composition, points to similar textile sources, which, as we have seen, are closely associated with the decorative trends from Constantinople. ${ }^{333}$ It is difficult to trace the flow of Constantinopolitan influence; however, it is likely that it arrived in Poreč through the transmission of trends from Ravennate bishops. In particular, the Istrian-born Bishop Maximian, who consecrated San Vitale in 547, funded the construction of Santa Maria del Canneto on Istrian land that was owned by the Ravennate church. $^{334}$

\section{Chapel of Santa Maria del Canneto, Santa Maria Formosa, Pula}

A small amount of stuccowork is found in a chapel dedicated to the Virgin that was originally attached to the non-extant Church of Santa Maria Formosa in the southern Istrian city of Pula. The church complex was commissioned and funded by Maximian, bishop of Ravenna from 546-557. According to Agnellus, Maximian was a native of Vistrum and had been ordained a deacon by the city's bishop prior to his appointment in Ravenna. ${ }^{335}$ Upon his ascension to the Episcopacy, Maximian travelled to Constantinople to meet with Justinian in order to resolve a conflict that had arisen in Vistrum, leading to the Ravennate church's acquisition of Istrian land. ${ }^{336}$ Agnellus writes,

"Both were by that time furnished with grey hairs; most bitterly together they began to mourn about all the things they remembered, cut off from youth and united in old age. Then this worthy emperor and augustus Justinian established an

\footnotetext{
333 Terry (1984): 289; Pasquini (2002):

${ }^{334}$ Deliyannis (2004): 184, n. 1; for a discussion of Ravenna's holdings see Gina Fasoli, "Il patrimonio della chiesa Ravennate," Storia di Ravenna ed. Antonio Carile, vol. 2, bk. 1, (Venice, 1991): 389-400.

335 Deliyannis (2004): 184.

${ }^{336}$ Mackie (2003): 47.
} 
injunction for him about that forest, that it be perpetually and legally part of the holy church of Ravenna..., 337

It was on this land that Maximian built Santa Maria Formosa, which included two adjoining side-chapels. (fig. 97) The southern chapel, which no longer survives, was dedicated to St. Andrew, while the extant northern chapel was dedicated to Santa Maria del Canneto. It has a Latin-cross plan and is similar in appearance to the so-called Mausoleum of Galla Placidia in Ravenna, albeit made from limestone blocks. ${ }^{338}$ (fig. 98) In a study from the 1920s, Antonio Morassi claims to have seen pieces of the original mosaic decoration in situ. ${ }^{339}$ The panel, now located in the Pula Archaeological Museum, provides evidence for a lavish decorative program, which indicates that the building was generously funded. ${ }^{340}$

Today, the only decorative element that survives in situ are the remains of a stuccowork program. The chapel's extant stuccowork consists of a fragmentary cornice found in the eastern apse and a wreath-and-garland motif in the domical vault. The stuccoes found in this chapel are very similar to the examples discussed from Poreč and include bird and vegetal motifs. In addition, the wreath-and-garland motif of the chapel's vault can be viewed as a three dimensional version of the mosaic wreath-and-garland in the presbytery groin vault at San Vitale. (fig. 99; cf. fig. 75) The preservation of the chapel's stuccowork provides an understanding of how chapels in the Istrian peninsula were decorated during the sixth century. The architectural similarities between the Mausoleum of Galla Placidia and the Chapel of Santa Maria delle Canneto suggest

\footnotetext{
${ }^{337}$ Deliyannis (2004): 189.

${ }^{338}$ Pasquini (2002): 63; Mackie (2003): 49.

339 Antonio Morassi, "La chiesa di Santa Maria Formosa o del Canneto in Pola," Bolletino d'Arte IV (124125): 11-26.

${ }^{340}$ Mackie (2003): 48.
} 
similarities in their decorative programs. However such assumptions should be made cautiously, due to the chronological differences in fifth and sixth century architectural decoration. Conspicuous connections can be made, based on stylistic grounds, between the cities of the sixth-century Adriatic, as evidenced by the material presented above. These connections allow scholars to trace the influence of sixth-century non-classical styles to the popularity of abstraction and stylization of contemporary Constantinopolitan architectural decoration.

\section{Hagia Sophia, Constantinople}

This discussion of sixth-century stuccowork ends with the best-known building from the period, the Church of Hagia Sophia in Constantinople. Built in five years by Justinian, it has long been recognized as the most innovative structure of the early Byzantine period. The expanded-dome basilica church was built atop the ruins of Theodosius' church, which was destroyed during the Nika Riots of 532. For decades, scholars have recognized Hagia Sophia's architectural and decorative achievements, which have, throughout its history, been the subject to numerous restorations and renovations. ${ }^{341}$ The lavish interior decoration includes the installation of an extensive architectural sculpture program that includes marble revetment, opus sectile, and the most intricately carved marble sculpture found anywhere in the Empire. As with the churches discussed above, these lavish materials were placed alongside less-costly stucco elements.

\footnotetext{
${ }^{341}$ For an architectural survey see Rowland J. Mainstone, Hagia Sophia: Architecture, Structure, and Liturgy of Justinian's Great Church $2^{\text {nd }}$ edition (London: Thames and Hudson, 2002). For a collection of essays on the monument's architecture, decoration, and historical context see Robert Mark and Ahmet S. Çakmak, Hagia Sophia from the age of Justinian to the Present (Cambridge: Cambridge University Press, 1992).
} 
Hagia Sophia's original stuccowork program is limited to a fragmentary cornice in the southwestern esonarthex, below the tenth-century tympanum mosaic of the Virgin and Child between Emperors Justinian and Constantine. (fig. 100) A brief analysis of the stucco cornice was undertaken during the 1960s during mosaic restoration work conducted by the Byzantine Institute of America. ${ }^{342}$ The cornice is on the east and west walls of the esonarthex above the marble revetment and below the mosaics of the vault. It is composed of a repeating pattern of swirling acanthus leaves that form circles, and filled with rosettes, four-petalled flowers, grapes, and other vegetal motifs. The placement and subject matter of this cornice are consistent with the stuccowork examples found throughout the Empire and illustrate a continuity of style that most-likely emanated from the imperial capital. This hypothesis is supported by the absence of early Byzantinestyle stuccowork in Ravennate churches prior to the construction of San Vitale, a building that exhibits strong connections with Constantinopolitan trends. The high-level of workmanship present in the stucco cornice indicated, to scholars, that the stuccoes were installed with the use of molds, which ensured a uniform application to which further details could be incised by the stuccoist. ${ }^{343}$

The stucco cornice in Hagia Sophia's southwestern vestibule provides scholars with a definitive example of sixth-century Constantinopolitan stuccowork trends, which is notable due the lack of evidence for stuccowork in other sixth-century churches like Hagia Eirene and S.S. Sergius and Bacchus. The consistency of the decoration also indicates that stuccowork installed in the imperial capital was likely applied with the use of molds, something that is not inferred in the contemporary stuccoes of Italy and Istria.

\footnotetext{
${ }^{342}$ Hawkins (1964): 131-135.

${ }^{343}$ Ibid., 132
} 
Stuccoes of the west, however, illustrate conspicuous stylistic connections to Constantinople through the emphasis on pattern and stylization of organic forms. Additionally, the conspicuous lack of figural (human) imagery in early Byzantine stuccoes indicates a separation from the late antique world, which, as demonstrated in chapter 5, exploited its connection to classical antiquity. Kitzinger describes this period of transition as one that is defined by a sense of "seemingly conflicting forces and traditions [that] were balanced out in a state of controlled tension." ${ }^{344}$ The shift from classical styles, which used stucco as a medium to render the human form, to the preference for abstract and stylized forms in the sixth century illustrates the political transformation of Ostrogothic Italy and Istria, which was deliberately modeled on the classical past, into the provinces of the early Byzantine Empire. ${ }^{345}$

\footnotetext{
${ }^{344}$ Kitzinger (1977): 81.

${ }^{345}$ Ibid., 81-98.
} 


\section{CHAPTER 8}

\section{LOMBARD AND UMAYYAD STUCCOWORK: REVISITING THE PAST?}

A brief examination of stuccowork from the periods that immediately follow the early Byzantine reconquest of Italy provides an important supplement to the variable quality and quantity of the material. As we have seen, early Byzantine stuccowork was characterized by an emphasis on the abstraction and stylization of natural forms, which found their prototypes in the textiles of Sasanian Persia. The period was noted for its employment of stucco as a textural wall covering, which strayed from the sculptural quality of the stucco figures from the previous century. Moving forward into the Lombard and Umayyad periods, we find the reintegration of the human figure in stucco alongside abstracted and stylized floral, vegetal, and geometric motifs. The combination of these two styles was used by the Lombard kings of Italy and the Umayyad caliphs of the Near East in an effort to legitimize their newly acquired political and religious authority by hearkening back to the authority of the past.

In the wake of Justinian's death in 565, the vastly expanded Empire was subject to a new series of political and military threats. ${ }^{346}$ In the west, the threat came from a Germanic group called the Lombards, led by Alboin, who successfully invaded northern

\footnotetext{
${ }^{346}$ John Haldon, "Political-Historical Survey, 518-800," The Oxford Handbook of Byzantine Studies (Oxford: Oxford University Press, 2008): 253.
} 
Italy in 568/9 and established a kingdom that lasted until $774 .^{347}$ Similar to other Germanic groups, Lombard political organization was, initially, based on a system of chieftains. $^{348}$ The nomination and election process in the early period, while difficult to reconstruct, was closely associated with the rise of military leaders. ${ }^{349}$ Over time, military leaders began to model their leadership upon the Ostrogothic notion of rex, a title claimed by Theoderic in the fifth century. ${ }^{350}$ The new Lombard kings of the seventh century clarified the title by calling themselves Rex gentis Langobardorum, King of the Lombard people. $^{351}$ Along with this new title, kings began to create a legal system based on Byzantine models. In 643 King Rothari issued an edict that established a calendar based on the succession of Lombard kings in which year 1 was equivalent to the beginning of the reign of Alboin. ${ }^{352}$ The edict also included language that revealed Rothari's desire to place his authority within a Christian context, albeit one that was rooted in a Germanic expression of Roman law. ${ }^{353}$

By the end of the seventh century, the Lombard kingdom had officially converted to Orthodoxy, which aligned it, theologically, with the Byzantine court at Constantinople. It should be noted that during this period of Lombard rule, the Byzantine Empire

\footnotetext{
${ }^{347}$ For historical overviews of this period see Walter Pohl, "Invasions and Ethnic Identity," Italy in the Early Middle Ages ed. Cristina La Rocca (Oxford: Oxford University Press, 2002): 21-27; ibid., "Justinian and the Barbarian Kingdoms," The Cambridge Companion to the Age of Justinian (Cambridge: Cambridge University Press, 2005): 448-476; and Haldon (2008): 253-255.

${ }^{348}$ Dick Harrison, "Political Rhetoric and Political Ideology in Lombard Italy," Strategies of Distinction: The Construction of Ethnic Communities, 300-800, ed. Walter Pohl and Helmut Reimitz (Leiden: Brill, 1998): 241-254.

${ }^{349}$ Stefano Gasparri, "Kingship Rituals and Ideology in Lombard Italy," Rituals of Power: From Late Antiquity to the Early Middle Ages, ed. Frans Theuws and Janet L. Nelson, (Leiden: Brill, 2000): 95-114; and Jörg Jarnut, "Gens, rex and regnum of the Lombards," Regna and Gentes: The Relationship Between Late Antique and Early Medieval Peoples and Kingdoms in the Transformation of the Roman World, ed. H.-W. Goetz, et al. (Leiden: Brill, 2003): 409-428.

${ }^{350}$ Pohl (2002): 23.

${ }^{351}$ Ibid., 23.

${ }^{352}$ Harrison (1998): 242-243.

${ }^{353}$ Ibid., 243.
} 
continued to occupy portions of Italy. However, these areas were limited to the exarchate of Ravenna and portions of the Dalmatian coast, which included the Istrian peninsula. Contact between Lombards and Byzantines would have been common, which led to the transfer of artistic and architectural trends across political borders. While the impact of native Lombard art on Byzantine trends is a subject for further investigation, the influence of Byzantium, and to a greater extant, of classical antiquity, on Lombard art and architecture is visible in the built environment. As discussed in chapter 6, the tendency for Germanic tribes to base their government and architecture upon Roman and Byzantine models helped to provide legitimacy to their newly established kingdoms. A survey of Lombard architecture reveals strong connections to the classical past, especially in church architecture and decoration. This is on display at the Monastery of Santa Maria in Valle in Cividale.

The foundation of this monastery, which is located in the Gastalaga district of Cividale, dates to the eighth century. ${ }^{354}$ Several monastic buildings survive; however, only the so-called Tempietto Longobardo dates to the original phase of construction. The Tempietto's patronage has been debated, but archaeological evidence indicates that it was built during the reign of King Astolfo (752-755). ${ }^{355}$ The Tempietto's architectural plan includes a vaulted aula, or open room, which exhibits a large amount of the original decorative program, that is followed by an area described as a presbytery, which is covered by a series of three barrel vaults. (fig. 101)

The decorative program of the Tempietto Longobardo includes, among other materials, stuccowork and fresco programs. It has been suggested that the frescoes,

\footnotetext{
${ }^{354}$ Pasquini (2002): 85; Silvia Cernuschi, "L'iscrizione dipinta del Tempietto," Cividale Longobarda: Materiali per una rilettura archeologia ed. Silvia Lusuardi Siena (Milan: Università Cattolica, 2002): 168. ${ }^{355}$ Siena (2002): 168.
} 
which were added at a later date, were installed in place of an original stuccowork program that had not been completed. ${ }^{356}$ According to Siena, the stuccowork program was intended to cover all of the wall surfaces of the aula, at the level of fenestration, and would have continued the design of the stuccowork that is currently found above the structure's entrance on the western wall. (fig. 102) The completed stuccowork is found on two levels, one that forms an arcuated lintel above the western entrance, and a second level that includes a series of six standing female figures that confront a central niche, which is covered by another arcuated lintel made of stucco. (fig. 103)

The stuccowork of the Tempietto illustrates different installation processes than those described in chapters 6 and 8 and is more closely related to marble relief sculpture. The intricate nature of the arcuated lintels that cover the western entrance and the niche of the second level indicates that the stuccos were carved from a dry plaster compound and then installed, fully finished, onto the walls. This technique mirrors the production of marble relief sculpture, which is further emphasized by the extraordinarily high relief of the stuccoes. The stucco figures present in the second level are carved in such high relief that they can almost be described as sculptures in the round. (fig. 104) Three figures stand on either side of an open niche, which originally contained a statue of Christ. Two figures, dressed in simple garments, stand on either side of this niche, gesture towards it and are, themselves, flanked by four additional figures who stand frontally and are dressed in elaborate garments usually associated with the aristocracy. The identification of these figures has been the source of scholarly debate for decades.

\footnotetext{
${ }^{356}$ Pasquini (2002): 85-86; Silvia Lusuardi Siena, "Per una rilettura delle fasi edilizie del Tempietto," Cividale Longobarda: Materiali per una rilettura archeologia, ed. Silvia Lusuardi Siena (Milan: Università Cattolica, 2002): 224-226.
} 
They have been variously identified as saints, martyrs, and royalty. ${ }^{357}$ The overall style of these stuccoes, from the elaborately carved lintels to the exaggerated contrapposto of the standing figures, can be most accurately described as classicizing. The use of these classical styles in the decorative program was an effective way for Lombards to legitimize their political authority. ${ }^{358}$ Moreover, the explicit use of stucco to render the human figure recalls the monumental figural stuccowork of the late antique period, which was, as discussed above, reminiscent of imperial Roman stuccowork.

The stuccoes of the Tempietto Longobardo also find parallels in the elaborate stuccowork found in the mid-seventh to mid-eighth century Umayyad caliphate in the Near East. ${ }^{359}$ The connection between the Lombard and Umayyad decorative programs may, at first, seem tenuous due to the vast geographical, political, and religious differences. However, the two groups shared a common source of influence: the Byzantine Empire. Scholars of the Islamic Near East have, for decades, traced connections between the monuments of the Umayyad and early Byzantine periods, beginning with the Byzantine workmanship of the mosaics found in the Dome of the Rock. $^{360}$

\footnotetext{
${ }^{357}$ H.P. L'Orange, “L'originaria decorazione del Tempietto cividalese," Atti del II congresso di studi sull'arte dell'Alto Medioevo (1953): 95-113; Hjalmar Torp, "Il problema della decorazione originaria del Tempitto Longobardo di Cividale del Friuli," Quaderni della FACE; Familia rtisti Cattolici Ellero, (1959): 1-47; Sergio Tavano, "Tradizioni tardoantiche nel 'Tempietto longobardo' di Cividale," Atti dell'Accademia di scienze, lettere e arti di Udine LXXIX (1986): 153-186; Marilena Casirani, et al., "Dati per una riconsiderazione del Tempietto longobardo," Cividale Longobarda: Materiali per una rilettura archeologia, ed. Silvia Lusuardi Siena (Milan: Università Cattolica, 2002): 133-136; and Pasquini (2002): 88.

${ }^{358}$ This is a technique that was used outside of architectural decoration and occurred in the production of portable classicizing Lombard objects such as the silver gilt Hen and Chicks statue group that was sent on behalf of Queen Theodolinda (590-628) to Pope Gregory the Great. Ross Balzaretti, "Theodelinda, 'Most Glorious Queen': Gender and Power in Lombard Italy,” The Medieval History Journal 2:2 (1999): 183-207.

${ }^{359}$ Isabella Vaj, "Il tempietto di Cividale e gli stucchi omayyadi," Cividale Longobarda: Materiali per una rilettura archeologia, ed. Silvia Lusuardi Siena (Milan: Università Cattolica, 2002): 175-204.

${ }^{360}$ Hamilton A. R. Gibb, "Arab-Byzantine Relations under the Umayyad Caliphate," Dumbarton Oaks Papers 12 (1958): 219-233; Oleg Grabar, "The Umayyad Dome of the Rock in Jerusalem," Ars Orientalis
} 
After the rise of Islam in the Arabian peninsula, and the death of its founder, Muhammad in 632, political and religious leadership became a source of conflict. Initially, power was ceded to members of the Prophet's family and soon support for his father-in-law, Abu Bakr, led followers to acknowledge him as the first of the four Rashidun, or "rightly guided" caliphs. ${ }^{361}$ During the period of the Rashidun, military conquests of the Near East in previously held Byzantine provinces led to the formation of an increasingly defined Muslim state. ${ }^{362}$ The assassination of the final Rashidun, Ali, in 661 paved the way for the formation of the Umayyad Caliphate. Under the leadership of Muawiya, a man who had been the governor of Syria and who played a vital role in the military victories over the Byzantines, the Umayyad Caliphate ensured the protection and expansion of the Muslim world from its capital in Damascus. ${ }^{363}$ However, the emergence of a Muslim identity, under the governance of the Umayyad caliphs, was subject to the influence of the Near East's Sasanian past and its Byzantine present, which had only recently been subjugated. ${ }^{364}$ The combination of these two sources of influence in the built environment was not only inevitable, given the geography and history of the region, but also a deliberate method used by the caliphs to establish their political authority within the historical framework of the Near East, which recalls the use of classicizing architecture and decorative styles by the Lombards in Italy.

3 (1959): 33-62; ibid., "Islamic Art and Byzantium” in Dumbarton Oaks Papers 18 (1964): 69-88; Robert Hillenbrand, "Islamic Art at the Crossroads: East Verses West at Mshatta" in Studies in Medieval Islamic Architecture Vol. 1 (London: Pindar Press, 2001): 114-159; ibid., "The Classical Heritage in Islamic Art: The Case of Medieval Architecture" in Studies in Medieval Islamic Architecture Vol. 1 (London: Pindar Press, 2001): 225-242; Flood (2001): 139-183; Hugh Kennedy, The Byzantine and Early Islamic Near East (Aldershot: Ashgate Publishing Limited, 2006); Nadia Maria El Cheikh, Byzantium Viewed by the Arabs (Cambridge: Harvard University Press, 2003).

${ }^{361}$ Hugh Kennedy, The Prophet and the Age of the Caliphates $2^{\text {nd }}$ ed. (Harlow: Pearson, 2003): 51-52.

${ }^{362}$ For a discussion of these military activities, see Kennedy (2003): 52-81, esp. 52.

363 Ibid., 76-81; and Hugh Kennedy, "Byzantine-Arab diplomacy in the Near East from the Islamic conquests to the mid eleventh century," Byzantine Diplomacy ed. J. Shepard and S. Franklin (Aldershot: Ashgate, 1992): 133-143, reprinted in Kennedy (2006): IX, 135.

${ }^{364}$ For a complete discussion of these influences, see Talgam (2004): 48-97. 
The architectural decoration of Umayyad structures exhibited a similar combination of decorative materials as discussed throughout this study, which included marble, mosaic, and stuccowork. Scholars of the Umayyad period are fortunate that a large amount of stuccowork that coated the interior and exterior of a variety of structures survives. For the purposes of this study, the stuccowork found in the Umayyad palaces of the Near East provides a stylistic parallel for contemporary Lombard stuccowork. The stuccowork from the palaces of Khirbat al-Mafjar and Qasr al-Hayr West, while no longer in situ, contain the best and most extensive comparative examples. ${ }^{365}$

Umayyad stuccoes, similar to the stuccoes at Cividale, were carved from hardened plaster and, when fully finished, were applied to walls, vaults, and domes. ${ }^{366}$ The motifs employed in these stuccoes were both figural and non-figural, and comingled on the walls, vaults, and entryways of Near Eastern desert palaces. These lavish palaces have been compared, based on architectural similarities, to the construction of villas and fortresses in the Near East during the late antique period. ${ }^{367}$ The stuccowork programs found at both Khirbat al-Mafjar, near the modern city of Jericho, and Qasr al-Hayr West, located in the Syrian desert, exhibit a similar classicizing aesthetic as the one found in Cividale, albeit one that is seen through an Umayyad lens. Based on textual and archaeological analysis, the construction of these two palaces has been attributed to the patronage of either the caliph Hisham (724-743) or his successor Walid II (c. 743). ${ }^{368}$ The installation of deliberately classicizing styles of Byzantine and Sasanian motifs on

\footnotetext{
${ }^{365}$ For a complete study of these sites, see Talgam (2004); Pasquini (2002): 89.

${ }^{366}$ Vaj (2002): 184-185; R.W. Hamilton, "Carved Plaster in Umayyad Architecture," Iraq, 15:1 (1953): 47; Dominique Clévenot, Splendors of Islam: Architecture, Decoration and Ornament (New York: The Vendome Press, 2000): 105.

${ }^{367}$ Barbara Finster and J. Schmidt, “The origin of 'desert castles': Qasr Bani Muqatil, near Karbala, Iraq," Antiquity 79 (2004): 339-349.

${ }^{368}$ Talgam (2004): 3 and 19.
} 
the exterior and interiors of these desert palaces illustrates the desire of the Umayyad elite to exert their newly established political authority. As discussed above, the region had, only a century before, been under Byzantine control. The installation of fully mottled human figures alongside intricately carved geometric and vegetal motifs allowed Umayyad caliphs to place themselves, politically and culturally, within a long history of successful rulers of the Near East. ${ }^{369}$ (figs. 105-107) While differences are present in the compositional arrangement of Umayyad and Lombard stuccowork, the incorporation of classicizing styles and motifs is consistent. The deliberately classicizing style of Umayyad stucco provides an example of how the idea of recalling the classical past is an effective tool to promote political legitimacy.

The shift in power dynamics in the Lombard and Umayyad periods required rulers to place themselves within the social context of their newly conquered subjects. The most visible way to achieve this political authority was to incorporate past styles into newly constructed monuments. The use of stucco as a medium for rendering the human figure recalled Roman and late antique modes of representation, which had been abandoned during the early Byzantine period in favor of repeating patterns of floral and vegetal design. The combination of Byzantine styles with three-dimensional figural imagery allowed the Lombard kings of Italy and the Umayyad caliphs of the Near East to associtate their newly established centers of power with the successes of classical antiquity.

\footnotetext{
${ }^{369}$ Ibid., 73-97.
} 


\section{CONCLUSION}

The appearance of decorative stuccowork alongside marble revetment, opus sectile, and mosaic in a variety of historical, cultural, and religious contexts illustrates the adaptive quality of the material throughout the history of art. However, as demonstrated in the first chapter, the historiography of stucco scholarship is fairly limited and places an emphasis on material from the Roman period. The recent publication of Stucs et décors de la fin de l'Antiquité au Moyen Âge (Ve-XIIe siècle): Actes du colloque international tenu à Poitiers du 16 au 19 Septembre 2004 (2006) expanded the scholarship on stucco to include material from the late antique and medieval periods. ${ }^{370}$ Additionally, the work of Laura Pasquini has been influential in the interpretation of stuccowork found on the Italian and Istrian peninsulas and has proved to be an essential source on the subject. ${ }^{371}$

Even with the recent interest in stuccowork from the late antique and medieval periods, scholars have failed to identify and interpret the issues of the stylistic changes that occurred in stuccowork trends between the late antique and early Byzantine periods. These stylistic changes became apparent after the creation of a survey of late antique and early Byzantine stuccowork from Italy, Istria, and Constantinople. The results of this survey allowed me to address the issues associated with changes in style and to provide

\footnotetext{
${ }^{370}$ Christian Sapin, ed., Stucs et décors de la fin de l'Antiquité au Moyen Âge (Ve-XIIe siècle): Actes du colloque international tenu à Poitiers du 16 au 19 Septembre 2004 (Turnhout: Brepols Publishers, 2006).

${ }^{371}$ Pasquini (2002).
} 
an explanation for the transition from the figural stuccowork of late antiquity to the nonfigural trends of the early Byzantine period.

The investigation began with a discussion of the physical characteristics of stucco, which included an examination of the production and installation of stuccowork during the Roman period. It was imperative to begin with the Roman period because of the large amount of extant stuccowork, which, as stated, has been the focus of intense scholarly investigation. Next, a historical context of the late antique period was provided to trace the transfer of power between Rome, Milan, and Ravenna that occurred in the fourth and fifth centuries. The results of chapter 4 revealed the increased political authority of late antique bishops, who sought to place themselves in the company of Constantine and the "good emperors." The evidence for this was presented in chapter 5 where I discussed the use of classicizing stuccowork that connected fourth and fifthcentury structures to imperial Roman trends in architectural decoration. The most notable aspect of late antique stucco, which distinguished it from early Byzantine examples, was the inclusion of human figures. The figural stuccowork found in Rome and Ravenna illustrated direct stylistic connections to the figural trends of the Roman period, which helped to support the hypothesis that architectural decoration was used as a tool for promoting political legitimacy. The examination of the sixth-century historical context in chapter 6 revealed similar techniques that were used by the Ostrogoths upon the establishment of their kingdom under Odoacer and Theoderic.

After the reestablishment of Byzantine control during the reign of Justinian and the subsequent fall of the Ostrogothic kingdom, classicizing trends in architecture and architectural decoration were abandoned in favor of new styles that emanated from 
Constantinople. The examination of material from the early Byzantine period, found in chapter 7, revealed a stylistic shift that used stuccowork as a vehicle for the incorporation of abstracted and stylized vegetal forms, which found their source in the ecclesiastical monuments of Justinianic Constantinople. Furthermore, the installation of figural stuccowork was abandoned, due to its three-dimensionality, and any figures present in decorative programs were composed of mosaic, which emphasized the hieratic and otherworldly quality characterized by Constantinopolitan trends. ${ }^{372}$ The incorporation of Constantinopolitan decorative trends in the monuments of the Italian and Istrian peninsulas was an effective propagandistic tool that indicated the supremacy of the Byzantine authority.

The inclusion of Lombard and Umayyad stuccowork in chapter 8 provided additional evidence to support the notion that architectural decoration could be used as a tool for emphasizing political legitimacy. The most interesting aspect of the stuccowork of these two periods, which are roughly contemporary, albeit geographically disparate, was the return to the installation of monumental figural imagery. The stuccowork programs found at the Tempietto Longobardo in Cividale and the Umayyad desert palaces of the Near East illustrate a return to classicizing styles, albeit through distinct cultural lenses. The incorporation of such elements recalled the classicizing tendencies of late antiquity to revisit the successes of the past and indicates, once again, that architectural decoration was a popular means of expressing political and religious power.

\footnotetext{
${ }^{372}$ Kitzinger (1977): 81-98.
} 


\section{REFERENCES}

Alföldy, Géza. "Diffillima Tempora: Urban Life, Inscriptions, and Mentality in Late Antique Rome." Urban Centers and Rural Contexts in Late Antiquity ed. Thomas S. Burns and John W. Eadie (East Lansing: Michigan State University Press, 2001): 3-24.

Allag, Claudine and Nicole Blanc. "Vouneuil et la tradition des stucs antiques." Stucs et décors de la fin de l'Antiquité au Moyen Âge (Ve-XIIe siècle): Actes du colloque international tenu à Poitiers du 16 au 19 Septembre 2004 (2006): 105-114.

Andreescu-Treadgold, Irina. "The Wall Mosaics of San Michele in Africisco, Ravenna, Rediscovered." Corso di cultura sull'arte Ravennate e Bizantine 37 (1990): 1357.

Andreescu-Treadgold, Irina. "The Mosaic Workshop at San Vitale." Mosaici a S. Vitale e altri restauri: il restauro in situ di mosaici parietali. Atti del Convegno nazionale sul restauro in situ di mosaici parietali: Ravenna 1-3 ottobre 1990, ed. Anna Maria Iannucci (1992): 31-41.

Andreescu-Treadgold, Irina. "The Emperor's New Crown and St. Vitalis' New Clothes." Corso di cultura sull'arte Ravennate e Bizantine 41 (1994): 149-186.

Andreescu-Treadgold, Irina and Warren Treadgold. "Procopius and the Imperial Panels of S. Vitale." Art Bulletin 79 (1997): 708-723

Angiolini, Patrizia. La Basilica di San Vitale a Ravenna. Modena: F.C. Panini, 1997.

Arce, Ignacio. "The Umayyad Carved Stucco from Amman Citadel Congregational Mosque." Lo Stucco Proceedings of the XVII International Conference "Scienza e Beni Culturali" (2001): 107-123.

Asgari, N. "The Proconnesian production of architectural elements in late antiquity, based on evidence from the marble quarries," in Constantinople and its Hinterland edited by Cyril Mango and Gilbert Dagron (Aldershot: Ashgate Publishing Limited, 1993): 263-288.

Augenti, Andrea. "Archeologia e topografia a Ravenna: il Palazzo di Teodorico e la Moneta Aurea." Archeologia Medievale 31 (2005): 7-34. 
Augenti, Andrea. "The Palace of Theoderic at Ravenna: a New Analysis of the Complex," in Housing in Late Antiquity: From Palaces to Shops edited by Luke Lavan, et al. (Leiden: Brill, 2007), pp. 425-453.

Bagnall, Roger S. Egypt in the Byzantine World: 300-700. Cambridge: Cambridge University Press, 2007.

Ball, L.F. "How did the Romans install revetment?" American Journal of Archaeology 106 (2002), pp. 551-573.

Balzaretti, Ross. "Theodelinda, 'Most Glorious Queen': Gender and Power in Lombard Italy." The Medieval History Journal 2:2 (1999): 183-207.

Bardill, Jonathan. "The Great Palace of the Byzantine emperors and the Walker Trust excavations.” Journal of Roman Archaeology 12:1 (1999): 216-230.

Bardill, Jonathan. "A New Temple for Byzantium: Anicia Juliana, King Solomon, and the Gilded Ceiling of the Church of St. Polyeuktos in Constantinople" Social and Political Life in Late Antiquity ed. William Bowden, et al. (Leiden: Brill, 2006): 339-370.

Bertacchi, L. “Architettura e mosaico, Grado, S. Maria delle Grazie.” Da Aquileia a Venezia: una mediazione tra l'Europa e l'Oriente dal II secolo a.C. al VI secolo d.C. (Milano: Libri Scheiwiller, 1980): 295-298.

Bolman, Elizabeth. "The Red Monastery Conservation Project, 2004 Campaign: New Contributions to the Corpus of Late Antique Art." Interactions: Artistic Interchange Between the Eastern and Western Worlds in the Medieval Period, ed. Colum Hourihane (Princeton: Index of Christian Art, 2007): 260-281.

Bolman, Elizabeth. "Late Antique Aesthetics, Chromophobia, and the Red Monastery, Sohag, Egypt." Eastern Christian Art 3 (2006): 1-24.

Bolman, Elizabeth. "The Red Monastery Conservation Project, 2006 and 2007 Campaigns: Contributing to the Corpus of Late Antique Art." Christianity and Monasticism in Upper Egypt vol. 1: Akhmim and Sohag, ed. Gawdat Gabra and Hany N. Takla, Saint Mark Foundation Book (Cairo: American University of Cairo Press, 2008): 305-317.

Bolman, Elizabeth. "Painted Skins: The Illusions and Realities of Architectural Polychromy, Sinai and Egypt." Approaching the Holy Mountain : Art and Liturgy at St Catherine's Monastery in the Sinai, eds. S.E.J. Gerstel and R.S. Nelson. Turnhout: Brepols, forthcoming. 
Bonelli, Massimo. "Rilevamento delle decorazioni in stucco altomedievali di Roma." Roma e l'età Carolingia (Roma: Multigrafica Editrice, 1976): 304-305.

Bracci Pinza, Maria Teresa. "Decorazioni in stucco degli edifici di culto paleocristiani di Ravenna." Felix Ravenna (1970): 151-167.

Bratož, Rajko. "The Development of the Early Christian Research in Slovenia and Istria Between 1976 NS 1986." Actes du XIe Congrès International d'Archéologie Chrétienne (1989): 2345-2388.

Bratož, Rajko. "Cristianesimo in Istria. Una sintesi e alcune riflessioni (con particolare riguardo allo sviluppo dell'organizzazione ecclesiastica)." Il Christianesimo in Istria fra tarda antichità e alto medioevo: Novita e riflessioni: Atti delle giornata tematica dei Seminari di Archeologia Cristiana (Roma-8 marzo 2007), ed. Emilo Marin and Danilo Mazzoleni (Città del Vaticano: Pontifico Istituto di Archeologia Cristiana, 2009): 9-46.

Britt, Karen. "Mosaics in the Early Byzantine Churches of Palestine: Innovation or Replication?” PhD diss., Indiana University, 2003.

Burns, Thomas S. and John W. Eadie, eds. Urban Centers and Rural Contexts in Late Antiquity. East Lansing: Michigan State University Press, 2001.

Cameron, Averil. "Remaking the Past." Interpreting Late Antiquity: Essays on the Postclassical World (Cambridge: The Belknap Press of Harvard University Press, 2001): 1-20.

Casirani, Marilena et al. "Dati per una riconsiderazione del Tempietto longobardo." Cividale Longobarda: Materiali per una rilettura archeologia, ed. Silvia Lusuardi Siena (Milan: Università Cattolica, 2002): 133-136.

Cernuschi, Silvia. "L'iscrizione dipinta del Tempietto." Cividale Longobarda: Materiali per una rilettura archeologia ed. Silvia Lusuardi Siena (Milan: Università Cattolica, 2002): 161-174.

Cheilik, Michael. "Opus Albarium: A Chronology of Roman Stucco Reliefs in Italy." PhD diss., Johns Hopkins University, 1965.

Creswell, K.A.C. "Coptic Influences on Early Muslim Architecture.” Bulletin de la société d'archéologie copte 6 (1938): 29-42.

Christie, Neil. From Constantine to Charlemagne: An Archaeology of Italy, AD 300-800. Burlington: Ashgate Publishing Company, 2006.

Clévenot, Dominique. Splendors of Islam: Architecture, Decoration and Ornament. New York: The Vendome Press, 2000. 
Codini, Laura. "La Chiesa di San Giovanni in Valle." Cividale Longobarda: Materiali per una rilettura archeologica ed. Silvia Lusuardi Siena (Milan: Università Cattolica, 2002): 89-107.

Cortesi, Giuseppe. "La Chiesa di S. Croce di Ravenna alla luce degli ultimi scavi e ricerche." Corso di cultura sull 'arte ravennate e bizantina (1978): 47-76.

Curran, John. Pagan City and Christian Capital: Rome in the Fourth Century. Oxford: Clarendon Press, 2000.

Debevoise, Neilson C. "The Origins of Decorative Stucco.” American Journal of Archaeology 45:1 (1941): 45-61.

Deichmann, Friedrich Wilhelm. Ravenna, Hauptstadt des spätantiken Abendlandes. Weisbaden: F. Steiner, 1974.

Deichmann, Friedrich Wilhelm. Ravenna, Hauptstadt des spätantiken Abendlandes. Wiesbaden: F. Steiner, 1976.

Deliyannis, Debora Mauskopf, trans. Agnellus of Ravenna: The Book of Pontiffs of the Church of Ravenna. Washington D.C.: The Catholic University of America Press, 2004.

Deliyannis, Deborah Mauskopf. Ravenna in Late Antiquity. Cambridge: Cambridge University Press, 2010.

Doig, Allen. Liturgy and Architecture: From the Early Church to the Middle Ages. Aldershot: Ashgate Publishing Company, 2009.

El Cheikh, Nadia Maria. Byzantium Viewed by the Arabs. Cambridge: Harvard University Press, 2003.

Fasoli, Gina. "Il patrimonio della chiesa Ravennate." Storia di Ravenna ed. Antonio Carile, vol. 2, bk. 1 (Venice, 1991): 389-400.

Finster, Barbara and J. Schmidt. “The origin of 'desert castles': Qasr Bani Muqatil, near Karbala, Iraq." Antiquity 79 (2004): 339-349.

Flood, Finbarr Barry. The Great Mosque of Damascus: Studies on the Makings of Umayyad Visual Culture. Leiden: Brill, 2001.

Fowden, Garth. Qusayr 'Amra: Art and the Umayyad Elite in Late Antique Syria. Berkley: University of California Press, 2004. 
Gapper, Claire. "What is 'Stucco'? English Interpretations of an Italian term." Architectural History, 42 (1999): 333-343.

Gaspari, Stefano. "Kingship Rituals and Ideology in Lombard Italy." Rituals of Power: From Late Antiquity to the Early Middle Ages, ed. Frans Theuws and Janet Nelson (Leiden: Brill, 2000): 95-114.

Gelichi, Sauro and Paola Novara. "La Chiesa di Santa Croce a Ravenna: la sequenza architettonica." Corso di cultura sull'arte ravennate e bizantina 42 (1995): 347382.

A. R. Gibb, Hamilton A.R. "Arab-Byzantine Relations under the Umayyad Caliphate." Dumbarton Oaks Papers 12 (1958): 219-233.

Gillett, Andrew. "Rome, Ravenna and the Last Western Emperors." Papers of the British School at Rome, 69 (2001): 131-167.

Gonosová, Anna. "The Formation and Sources of Early Byzantine Floral Semis and Floral Diaper Patterns Reexamined." Dumbarton Oaks Papers 41 (1987): 27237.

Gonosová, Anna. "Exotic Taste: The Lure of Sasanian Persia." Antioch: The Lost Ancient City ed. Christine Kondoleon (Princeton: Princeton University Press, 2000): 130-133, reprinted in Late Antique and Medieval Art of the Mediterranean World ed. Eva R. Hoffman (Malden: Blackwell Publishing Ltd, 2007): 40-46.

Grabar, Oleg. "The Umayyad Dome of the Rock in Jerusalem.” Ars Orientalis 3 (1959): 33-62.

Grabar, Oleg. "Islamic Art and Byzantium.” Dumbarton Oaks Papers 18 (1964): 69-88.

Haldon, John. "Political-Historical Survey, 518-800." The Oxford Handbook of Byzantine Studies (Oxford: Oxford University Press, 2008): 249-263.

Hamilton, R.W. “Carved Plaster in Umayyad Architecture.” Iraq 15:1 (1953): 43-55.

Hanfmann, George M.A. "The Continuity of Classical Art: Culture, Myth, and Faith." Age of Spirituality: A Symposium ed. Kurt Weitzmann (New York: Metropolitan Museum of Art, 1980): 75-99.

Hansen, Maria Fabricius. The Eloquence of Appropriation: Prolegomena to an Understanding of Spolia in Early Christian Rome. Rome, L'Erma di Breschneider, 2003.

Harmless, William. Desert Christians. Oxford: Oxford University Press, 2004. 
Harper, J. G. "The Provisioning of Marble for the sixth-century Churches of Ravenna: a reconstructive analysis," in Pratum Romanum: Richard Krautheimer zum 100. Gerburtstag. Wiesbaden, 1997, pp. 131-148.

Harrison, Dick. "Political Rhetoric and Political Ideology in Lombard Italy." Strategies of Distinction: The Construction of Ethnic Communities, 300-800, ed. Walter Pohl and Helmut Reimitz (Leiden: Brill, 1998): 241-254.

Harrison, Martin. Excavations at Saraçhane in Istanbul. Princeton: Princeton University Press, 1986.

Harrison, Martin. A Temple for Byzantium : The Discovery and Excavation of Anicia Juliana's Palace-Church in Istanbul. Austin: University of Texas, 1989.

Haselhoff, Albert. Pre-Romanesque Sculpture in Italy. New York: Harcourt, Brace and Company: 1931.

Hawkins, E.J.W. "Plaster and Stucco Cornices at Haghia Sophia, Istanbul." Actes du XIIe Congrés International d'études byzantines (1964): 131-135.

Hillenbrand, Robert. "Islamic Art at the Crossroads: East Verses West at Mshatta." Studies in Medieval Islamic Architecture Vol. 1 (London: Pindar Press, 2001): 114-159.

Hillenbrand, Robert. "The Classical Heritage in Islamic Art: The Case of Medieval Architecture." Studies in Medieval Islamic Architecture Vol. 1 (London: Pindar Press, 2001): 225-242.

Humfress, Caroline. "Law and Legal Practice in the Age of Justinian." The Cambridge Companion to The Age of Justinian ed. Michael Mass (Cambridge: Cambridge University Press, 2004): 161-184.

Holum, Kenneth. "Pulcheria's Crusade A.D. 421-22 and the Ideology of Imperial Victory." Greek, Roman, and Byzantine Studies 18 (1977): 153-172.

Holum, Kenneth. Theodosian Empresses: Women and Imperial Dominion in Late Antiquity. Berkley: University of California Press, 1982.

Jackson, M.D. et al. "The Judicious Selection and Preservation of Tuff and Travertine Building Stone in Ancient Rome." Archaeometry 47:3 (2005): 485-510.

James, Liz. "Byzantine glass mosaic tesserae: some material considerations." Byzantine and Modern Greek Studies 30:1 (2006): pp. 29-47.

Jarnut, Jörg. "Gens, rex and regnum of the Lombards." Regna and Gentes: The Relationship Between Late Antique and Early Medieval Peoples and Kingdoms in 
the Transformation of the Roman World, ed. H.-W. Goetz, et al. (Leiden: Brill, 2003): 409-428.

Johnson, Mark J. “Toward a History of Theodoric's Building Program.” Dumbarton Oaks Papers 42 (1988): 73-96.

Joyce, Hetty. The Decoration of Walls, Ceilings, and Floors in Italy in the Second and Third Centuries A.D. Roma: Giorgio Bretschneider, 1981.

Kaldellis, Anthony. Hellenism in Byzantium: The Transformations of Greek Identity and the Reception of the Classical Tradition. Cambridge: Cambridge University Press, 2007.

Kelly, J.N.D. Early Christian Doctrines. New York, Harper \& Row, Publishers: 1978.

Kennedy, Hugh. "Byzantine-Arab diplomacy in the Near East from the Islamic conquests to the mid eleventh century." Byzantine Diplomacy ed. J. Shepard and S. Franklin (Aldershot: Ashgate, 1992): 133-143, reprinted in Kennedy, The Byzantine and Early Islamic Near East. (Aldershot: Ashgate Publishing Limited, 2006): IX.

Kennedy, Hugh. The Prophet and the Age of the Caliphates $2^{\text {nd }}$ ed. Harlow: Pearson, 2003.

Kennedy, Hugh. The Byzantine and Early Islamic Near East. Aldershot: Ashgate Publishing Limited, 2006.

Kiilerich, Bente. Late Fourth Century Classicism in the Plastic Arts : Studies in the socalled Theodosian Renaissance. Odense: Odense University Press, 1993.

Kinney, Dale. "The Evidence for the Dating of S. Lorenzo." Journal of the Society of Architectural Historians 31 (1972): 92-107.

Kitzinger, Ernst. "The Hellenistic Heritage in Byzantine Art." Dumbarton Oaks Papers 17 (1963): 95-115.

Kitzinger, Ernst. Byzantine Art in the Making: Main lines of stylistic development in Mediterranean Art $3^{\text {rd }}-7^{\text {th }}$ Century. Cambridge: Harvard University Press, 1977.

Kleinbauer, W. Eugene. "Toward a dating of San Lorenzo in Milan: Masonry and Building Methods of Milanese Roman and Early Christian Architecture." Arte Lombarda XMII (1968): 1-22.

Kostof, Spiro K. The Orthodox Baptistery of Ravenna. New Haven: Yale University Press, 1965. 
Krautheimer, Richard. Corpus Basilicarum Christianarum Romae. Città del Vaticano: Pontificio Instituto di Archeologia Cristiana, 1937-1977.

Krautheimer, Richard. "Recent Publications on S. Maria Maggiore in Rome." American Journal of Archaeology 46:3 (1942): 373-379.

Krautheimer, Richard. "The Architecture of Sixtus III: A Fifth-Century Renascence?" Essays in Honor of Erwin Panofsky ed. Millard Meiss (New York: New York University Press, 1961): 291-302.

Krautheimer, Richard. Three Christian Capitals: Topography and Politics. Berkeley: University of California Press, 1983.

Krautheimer, Richard. Rome: Profile of a City, 312-1308. Princeton: Princeton University Press, 1983.

Lee, A.D. Pagans and Christians in Late Antiquity: A Sourcebook. London: Routledge, 2000.

Lee, A.D. "The Empire at War." The Cambridge Companion to The Age of Justinian ed. Michael Mass (Cambridge: Cambridge University Press, 2004): 113-133.

Lewis, Suzanne. "San Lorenzo Revisited: A Theodosian Palace Church at Milan." Journal of the Society of Architectural Historians 32 (1973): 197-222.

Ling, Roger. Stuccowork and Painting in Roman Italy. Aldershot: Ashgate Publishing Company, 1999.

Ling, Roger. "Some Roman Stucco Reliefs from Pozzuoli now in The British Museum." Papers of the British School at Rome 34 (1966): 24-33.

Ling, Roger. "Stucco decoration in pre-Augustan Italy." Papers of the British School at Rome 40 (1972): 11-58.

Ling, Roger. "Stuccowork." Roman Crafts (London: 1976): 209-221.

Ling, Roger. "Stucco Decorations at Baia." Papers of the British School at Rome 45 (1977): 24-51.

Ling, Roger. "Roman Paintings and Stucco Reliefs in the Victoria and Albert Museum." Papers of the British School at Rome 49 (1981): 46-58.

Lohuizen-Mulder, Mab. "Early Christian Lotus-panel capitals and other so-called Impost Capitals.” Bulletin Antieke Beschaving 62 (1987): 131-151. 
Lohuizen-Mulder, Mab. "The Cathedra of St. Mark in Venice." Bulletin Antieke Beschaving 63 (1988): 165-179.

Lohuizen-Mulder, Mab. “The Two-zone Capitals.” Bulletin Antieke Beschaving 64 (1989): 172-183.

Lohuizen-Mulder, Mab. "Stuccoes in Ravenna, Poreč, and Cividale of Coptic Manufacture.” Bulletin Antieke Beschaving 65 (1990): 139-156.

L'Orange, H.P. "L'originaria decorazione del Tempietto cividalese." Atti del II congresso di studi sull'arte dell'Alto Medioevo (1953): 95-113.

Mackie, G. Early Christian Chapels in the West. Toronto, University of Toronto Press, 2003.

MacCormack, Sabine G. Art and Ceremony in Late Antiquity. Berkley: University of California Press, 1981.

Mainstone, Rowland J. Hagia Sophia: Architecture, Structure, and Liturgy of Justinian's Great Church $2^{\text {nd }}$ edition. London: Thames and Hudson, 2002.

Mango, Cyril. "The Church of Saints Sergius and Bacchus at Constantinople and the Alleged Tradition of Octagonal Palatine Churches." Jahrbuch der österreichischen Byzantinistik 21 (1972): 189-193.

Mark, Robert and Ahmet S. Çakmak. Hagia Sophia from the age of Justinian to the Present. Cambridge: Cambridge University Press, 1992.

Mass, Michael. "Roman Questions, Byzantine Answers: Contours of the Age of Justinian." The Cambridge Companion to The Age of Justinian ed. Michael Mass (Cambridge: Cambridge University Press, 2004): 3-27.

Matejčić, Ivan. "Breve nota a novitá sulle decorazioni a stucco del periodo paleocristiano in Istria." Stucs et décors de la fin de l'Antiquité au Moyen Age (Ve-XIIe siècle): Actes du colloque international tenu à Poitiers du 16 au 19 Septembre 2004 (2006): 125-132.

McLynn, Neil. Ambrose of Milan: Church and Court in a Christian Capital. Berkeley: University of California Press, 1994.

Marazzi, Federico. "The Last Rome: From the End of the Fifth to the End of the Sixth Century." The Ostrogoths from the Migration Period to the Sixth Century: An Ethnographic Perspective, ed. S.J. Barnish and F. Marazzi (Woodbridge, The Boydell Press, 2007): 279-316. 
Miles, Margaret R. "Santa Maria Maggiore's Fifth-Century Mosaics: Triumphal Christianity and the Jews." The Harvard Theological Review 86:2 (1993): 155175.

Moorhead, John. Theoderic in Italy. Oxford: Clarendon Press, 1992.

Morassi, Antonio. "La chiesa di Santa Maria Formosa o del Canneto in Pola." Bolletino d'Arte IV (124-125): 11-26.

Novara, Paola. La cattedrale di Ravenna: storia e archeologia. Ravenna: D. Montanari, 1997.

Novara, Paola. "La Ravenna tardo imperiale." Ravenna Romana ed. Maurizio Mauro (Ravenna: Adriapress, 2001): 251-280.

Pasquini, Laura. "Elementi orientali-costantinopolitani nelle decorazioni a stucco di S. Vitale." Corso di cultura sull'arte Ravennate e bizantina (1994): 187-206.

Pasquini, Laura. "Gli stucchi della basilica Eufrasiana di Parenzo.” Ocnus, Quaderni della Schuola di Specializzazione in Archeologia IV (1996): 191-201.

Pasquini, Laura. La decorazione a stucco in Italia fra Tardo Antico e Alto Medioevo. Ravenna: Longo Editore, 2002.

Pasquini, Laura. "Il battistero della cattedrale cattolica a Ravenna." Venezia e Bisanzio: aspetti della cultura artistica bizantina da Ravenna a Venezia, V-XIV secolo (2005): 327-344.

Pavan, Gino. "Il problema della decorazione a stucco nelle basiliche ravennati alla luce degli ultimi ritrovamenti." Corso di cultura sull'arte ravennate e bizantina (1980) 137-165.

Penni Iacco, Emanuela. La Basilica di S. Apollinare Nuovo di Ravenna attraverso I secoli. Bologna: Università di Bologna, 2004.

Pohl, Walter. "Invasions and Ethnic Identity." Italy in the Early Middle Ages ed. Cristina La Rocca (Oxford: Oxford University Press, 2002): 11-33.

Pohl, Walter. "Justinian and the Barbarian Kingdoms." The Cambridge Companion to the Age of Justinian, (Cambridge: Cambridge University Press, 2005): 448-476.

Roldanus, Johannes. The Church in the Age of Constantine: The Theological Challenges. London: Routledge, 2006. 
Russo, Eugenio. "Scavi e scoperte nella chiesa di S. Agata di Ravenna. Notizie Preliminari." Actes du XIe Congrès international d'archéologie chrétienne: Lyon, Vienne, Grenoble, Genève et Aoste (1989): 2317-2341.

Russo, Eugenio. "L'Architettura di Ravenna paleocristiana." Venezia e Bisanzio: Aspetti della cultura artistica bizantina da Ravenna a Venezia (V-XIV secolo) ed. Clementina Rizzardi (Venice: Istituto Veneto di scienze, lettere ed arti, 2005): 89103.

Sapin, Christian, ed. Stucs et décors de la fin de l'Antiquité au Moyen Âge (Ve-XIIe siècle): Actes du colloque international tenu à Poitiers du 16 au 19 Septembre 2004. Turnhout: Brepols Publishers, 2006.

Sapin, Christian. "Vouneuil et les stucs de l'Antiquité tardive." Stucs et décors de la fin de l'Antiquité au Moyen Age (Ve-XIIe siècle): Actes du colloque international tenu à Poitiers du 16 au 19 Septembre 2004 (2006): 51-68.

Shapely, Joy. "The Stuccoes of San Vitale.” Studien zur Kunst des Ostens. Josef Strzygowski zum sechzigsten Geburtstage von seinen Freunden und Schülern (1923): 19-32.

Siena, Silvia Lusuardi. "Per una rilettura delle fasi edilizie del Tempietto." Cividale Longobarda: Materiali per una rilettura archeologia, ed. Silvia Lusuardi Siena, (Milan: Università Cattolica, 2002): 205-250.

Sivan, Hagith. Palestine in Late Antiquity. Oxford: Oxford University Press, 2008.

Šonje, A. "Gli stucchi della basilica eufrasiana di Parenzo." Felix Ravenna (1967): 5168.

Spain, Suzanne. “"The Promised Blessing”: The Iconography of the Mosaics of Santa Maria Maggiore.” Art Bulletin 61 (1979): 518-540.

Strong, D.E. “A Group of Roman Stucco Reliefs.” The British Museum Quarterly 21:4 (1959): 98-100.

Strong, Eugénie and Norah Jolliffe. "The Stuccoes of the Underground Basilica near the Porta Maggiore.” Journal of Hellenic Studies 44 (1924): 65-111.

Strzygowski, Josef. Orient oder Rom: Beiträge zur Geschichte der spätantiken und frühchristlichen Kunst. Leipzig: J.C. Hinrichs'sche Buchhandlung, 1901.

Strzygowski, Josef. "Orient or Rome: The Porphyry Groups at St. Mark's, Venice, as Test Case." trans. Iain Boyd White. Art in Translation 1:1 (2009): 61-76. Originally published in German as "Orient oder Rom. Stichprobe: Die 
Porphyrguppen von S. Marco in Venedig." C.F. Lehmann ed. Kilo: Beiträg zur alten Geschichte 2 (Leipzig: Dietrich'sche Verlagsbuchhandlung, 1902): 105-124.

Swift, Ellen. Style and Function in Roman Decoration: Living with Objects and Interiors. Farnham: Ashgate, 2009.

Talgam, Rina. The Stylistic Origins of Umayyad Sculpture and Architectural Decoration. Wiesbaden: Harrassowitz Verlag, 2004.

Tavano, Sergio. "Rilievi paleocristiani di Grado." Grado nella storia e nell'arte (1980): 355-371.

Tavano, Sergio. "Tradizioni tardoantiche nel 'Tempietto longobardo' di Cividale." Atti dell'Accademia di scienze, lettere e arti di Udine LXXIX (1986): 153-186.

Tavano, Sergio. Il Tempietto Longobardo di Cividale. Longobarde, 1990.

Terry, Ann. "The Architecture and Architectural Sculpture of the sixth-century Eufrasius Cathedral." PhD diss., University of Illinois at Urbana-Champaign, 1984.

Terry, Ann. "The Opus Sectile in the Eufrasius Cathedral at Poreč." Dumbarton Oaks Papers 40 (1986): 147-164.

Terry, Ann. "The Early Christian Sculpture at Grado: A Reconsideration." Gesta 26:2 (1987): 93-112.

Terry, Ann. "The Sculpture at the Cathedral of Eufrasius in Poreč." Dumbarton Oaks Papers 42 (1988): 13-64.

Terry, Anne and Henry Maguire. Dynamic splendor: the Wall Mosaics in the Cathedral of Eufrasius at Poreč. University Park: Pennsylvania State University Press, 2007.

Torp, Hjalmar. "Il problema della decorazione originaria del Tempitto Longobardo di Cividale del Friuli." Quaderni della FACE; Familia rtisti Cattolici Ellero (1959): $1-47$.

Urbano, Arthur. "Donation, Dedication, and Damnatio Memoriae: The Catholic Reconciliation of Ravenna and the Church of Sant'Apollinare Nuovo." Journal of Early Christian Studies 13:1 (2005): 71-110.

Vaj, Isabella. "Il tempietto di Cividale e gli stucchi omayyadi." Cividale Longobarda: Materiali per una rilettura archaeologica (Milan: Università Cattolica, 2002): 175-204.

Van Buren, A.W. "The Technique of Stucco Ceilings at Pompeii." The Journal of Roman Studies 14 (1924): 112-122. 
Vicelja-Matijašić, Marina. "Christological Program in the Apse of Basilica Eufrasiana in Poreč.” IKON (2008): 91-102.

Vitruvius. The Ten Books on Architecture trans. Morris Hicky Morgan. New York: Dover Publications, Inc., 1960.

Volpe, Guliano. "Architecture and Church Power in Late Antiquity: Canosa and San Giusto (Apulia)," Housing in Late Antiquity: From Palaces to Shops edited by Luke Lavan, et al. (Leiden: Brill, 2007), pp. 131-168.

M.B.W. "Stucco Reliefs from Nero's Palace." Bulletin of the Art Institute of Chicago 17:2 (Feb., 1923): 15-16.

Wadsworth, E.L. "Stucco reliefs of the first and second centuries still extant in Rome." Memoirs of the American Academy in Rome 4 (1924): 9-102.

Wataghin, Gisella Cantino. "Lo stucco nei sistemi decorative della tarda antica." Stucs et décors de la fin de l'Antiquité au Moyen Âge (Ve-XIIe siècle): Actes du colloque international tenu à Poitiers du 16 au 19 Septembre 2004 (2006): 115-124.

Wataghin, Gisella Cantino. "Architecture and Power: Churches in Northern Italy from the $4^{\text {th }}$ to the $6^{\text {th }}$ C." Social and Political Life in Late Antiquity (London: Brill, 2006): 287-309.

Wharton, Annabel Jane. "Ritual and Reconstructed Meaning: The Neonian Baptistery in Ravenna." The Art Bulletin 69:3 (1987): 358-375.

Zovatto, P.L. "La Basilica di S. Maria di Grado.” Memorie Storiche Forogiulesi XXXIX (1951): 14-33. 

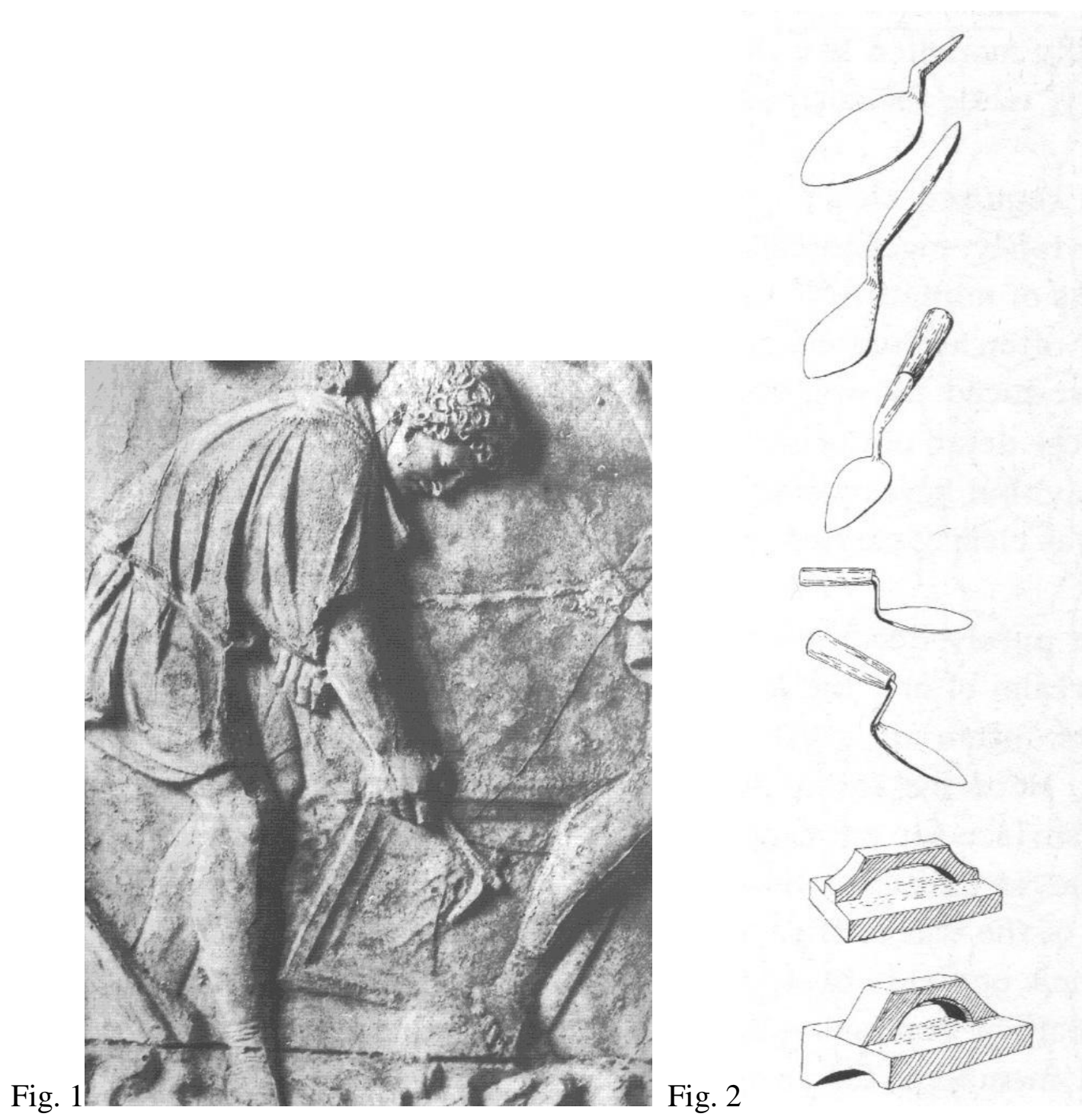


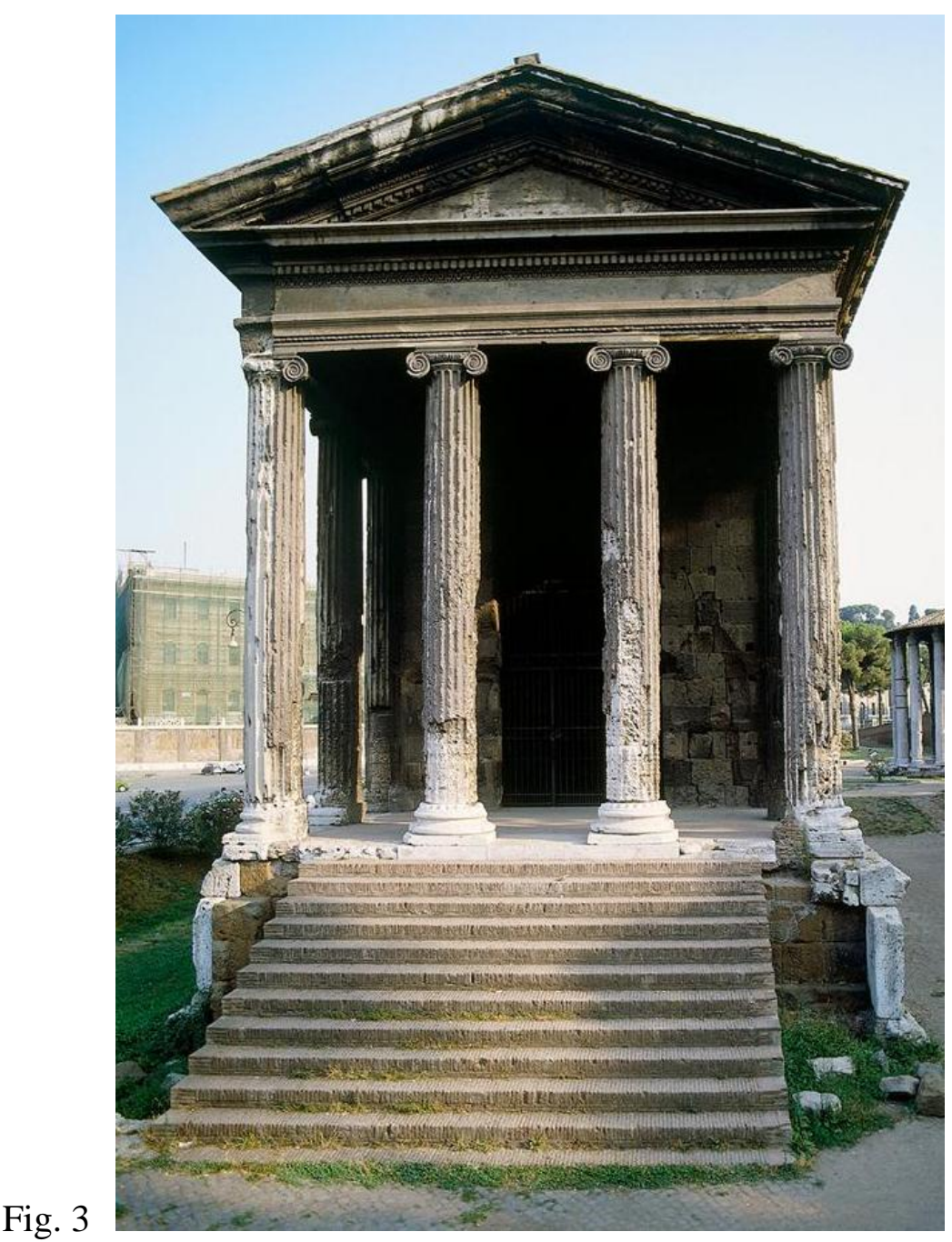

Fig. 3

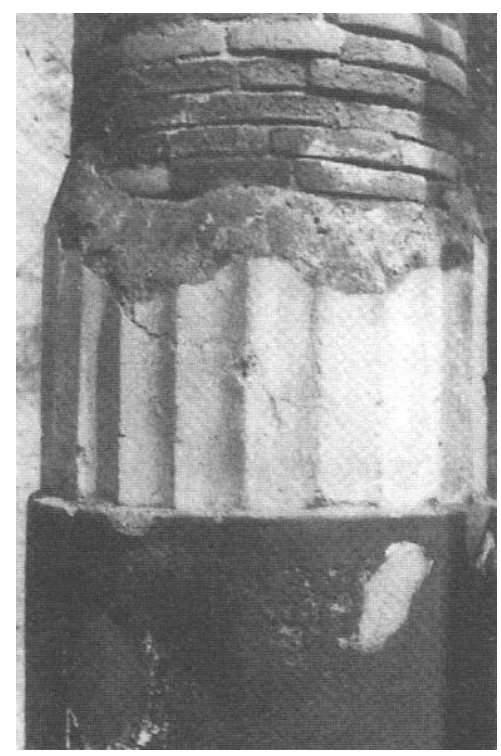




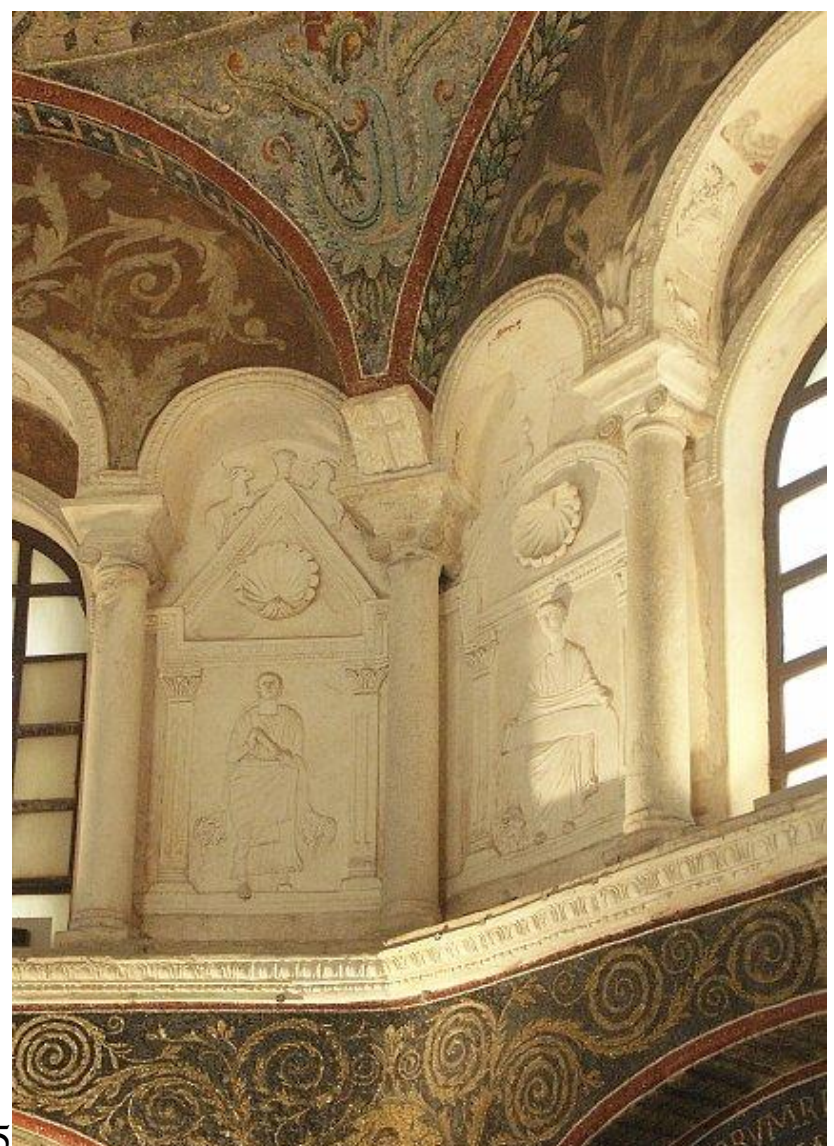

Fig. 5

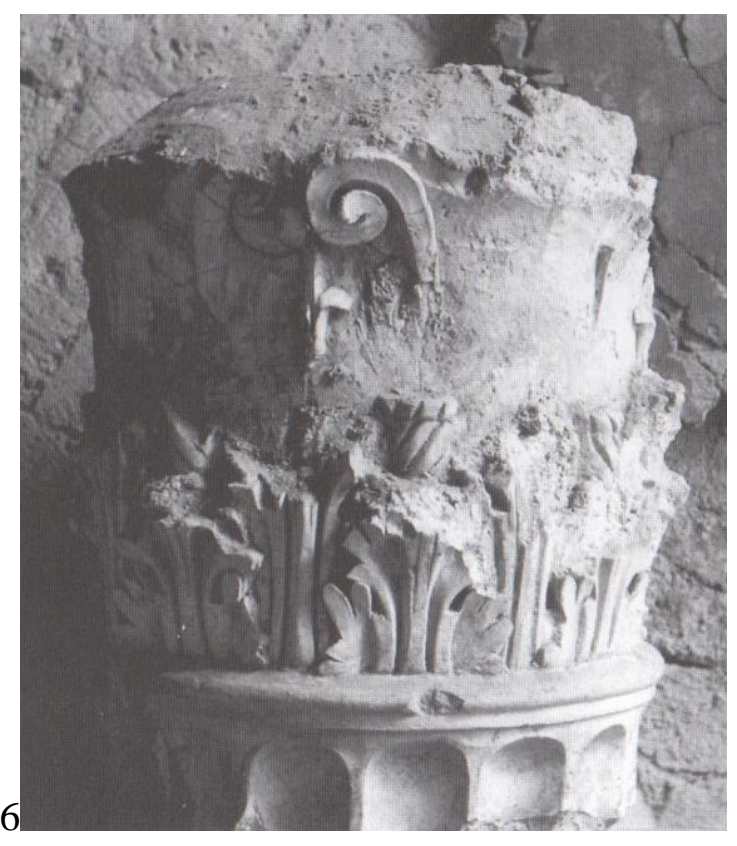




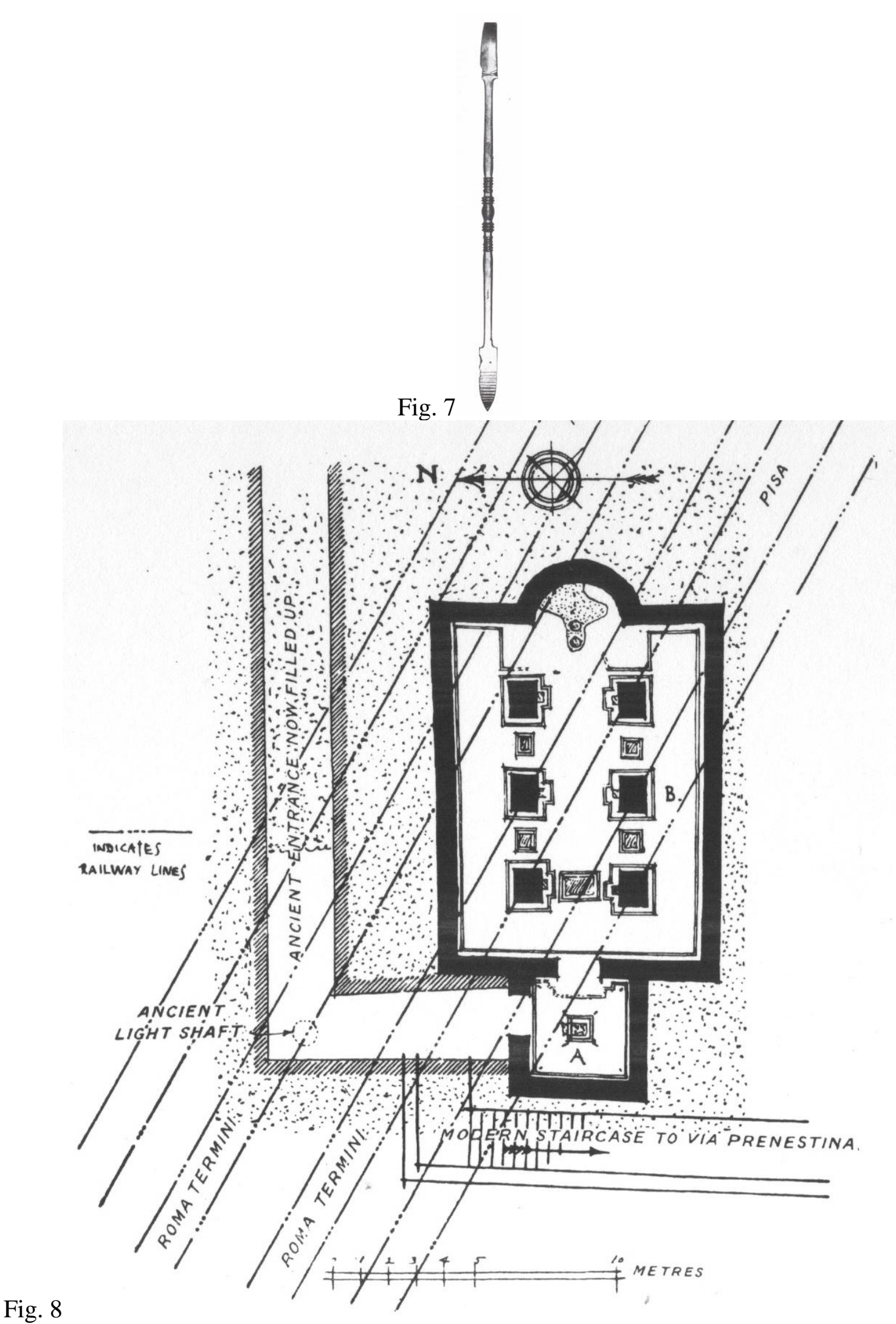




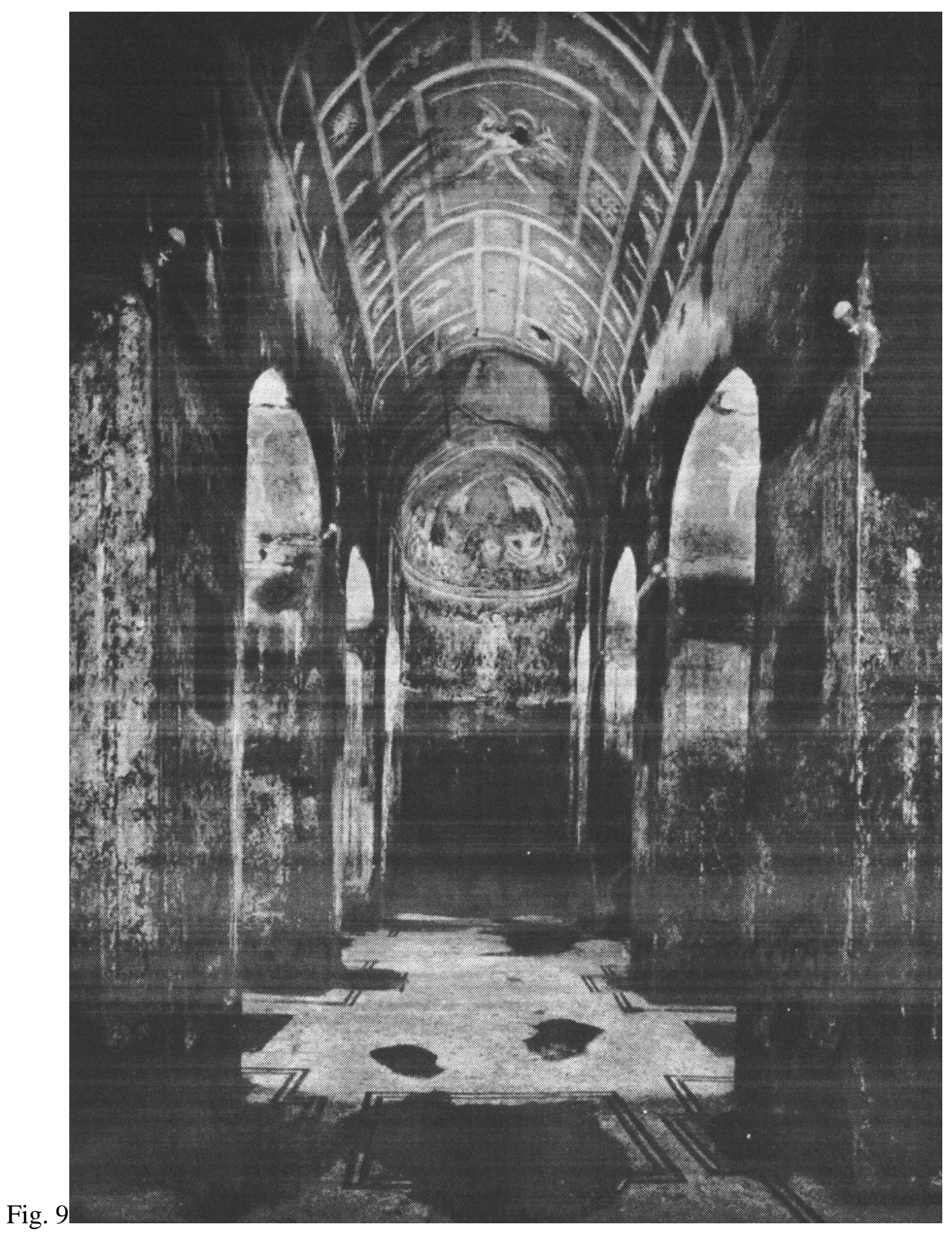




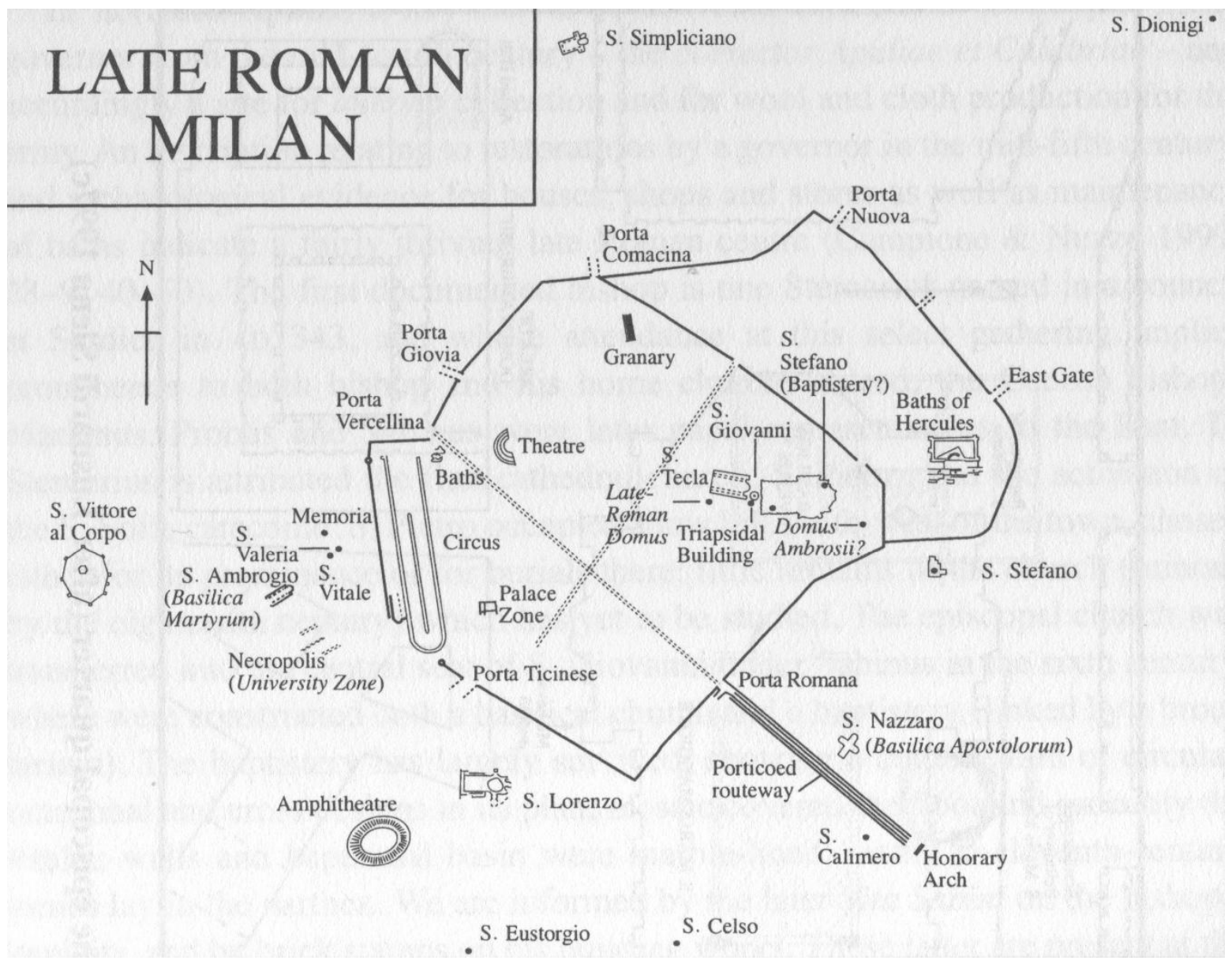

Fig. 10 


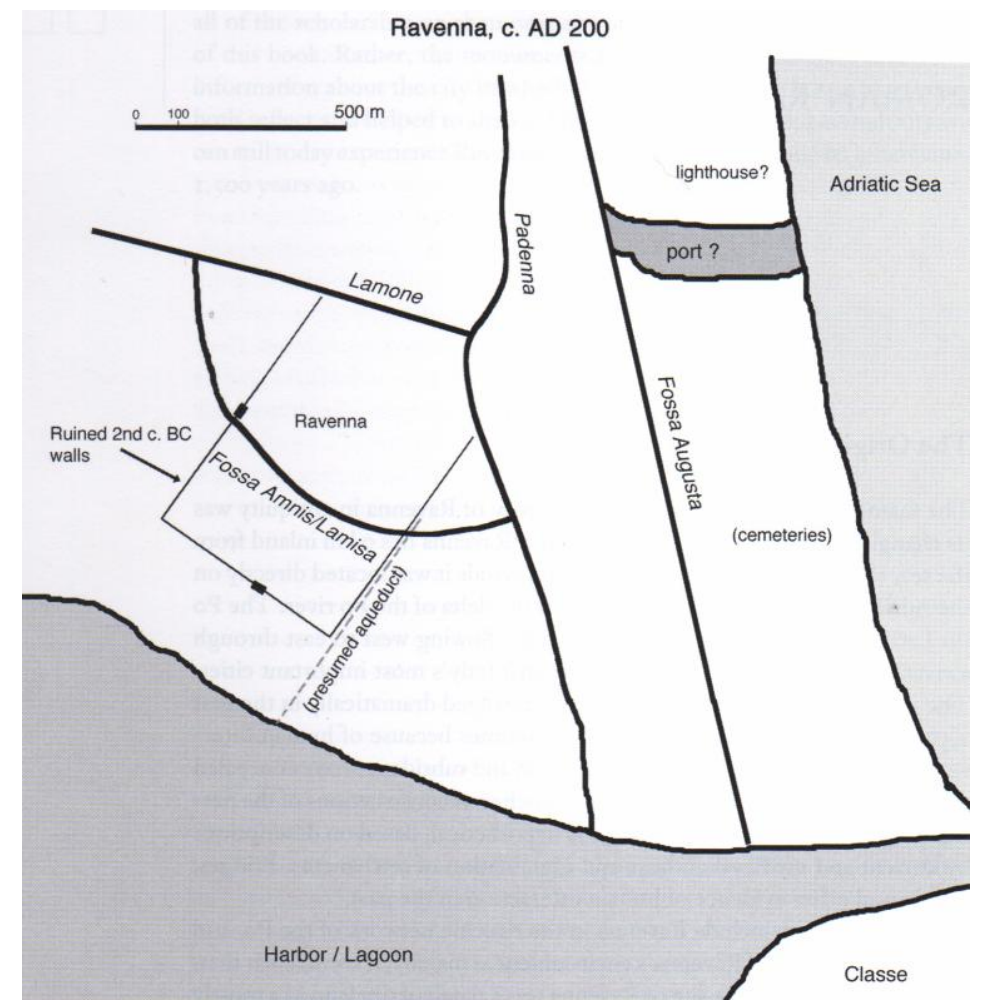

Fig. 11

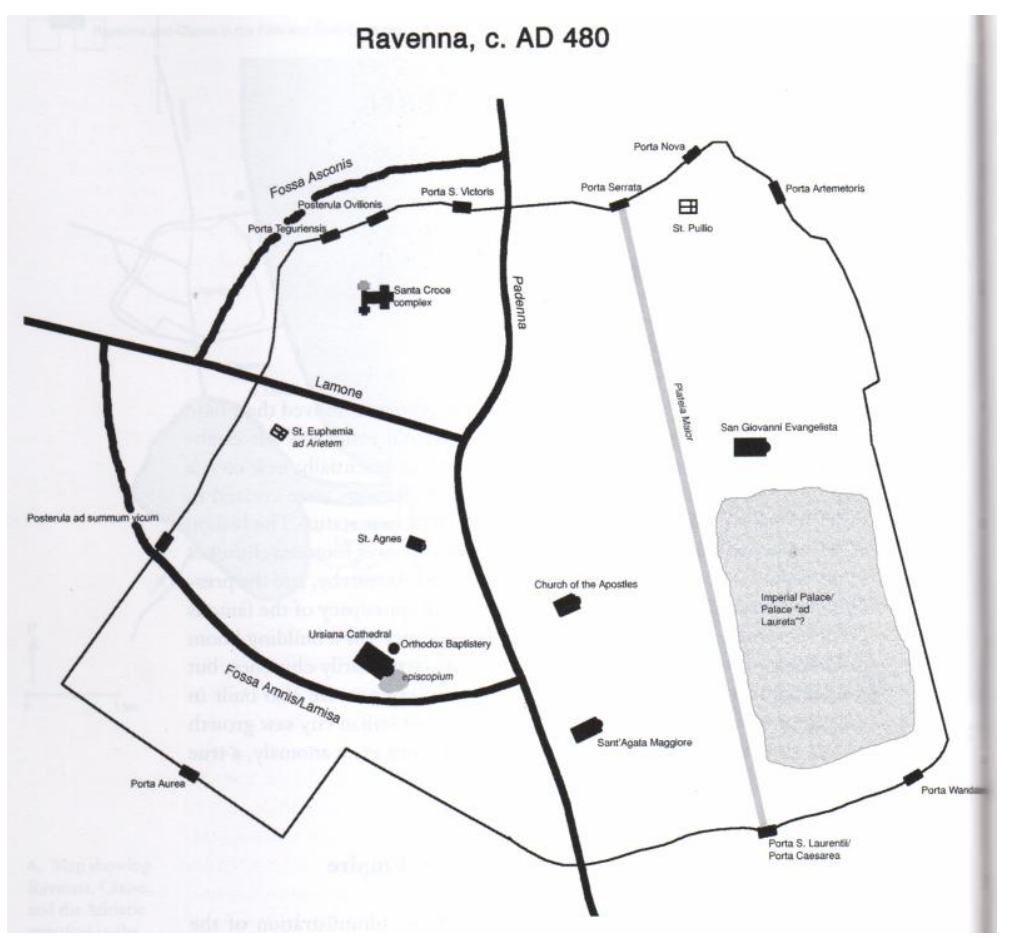

Fig. 12 

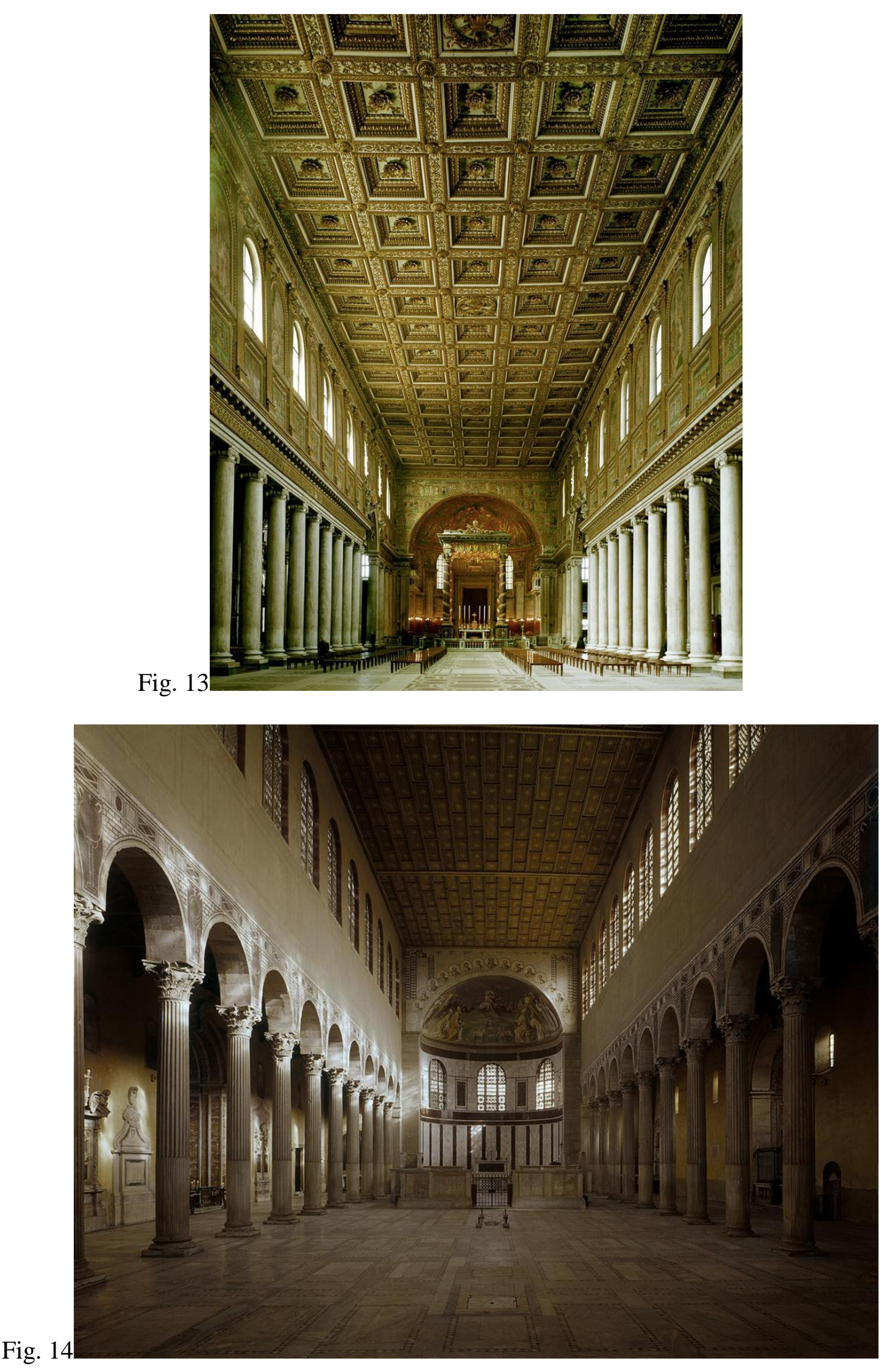


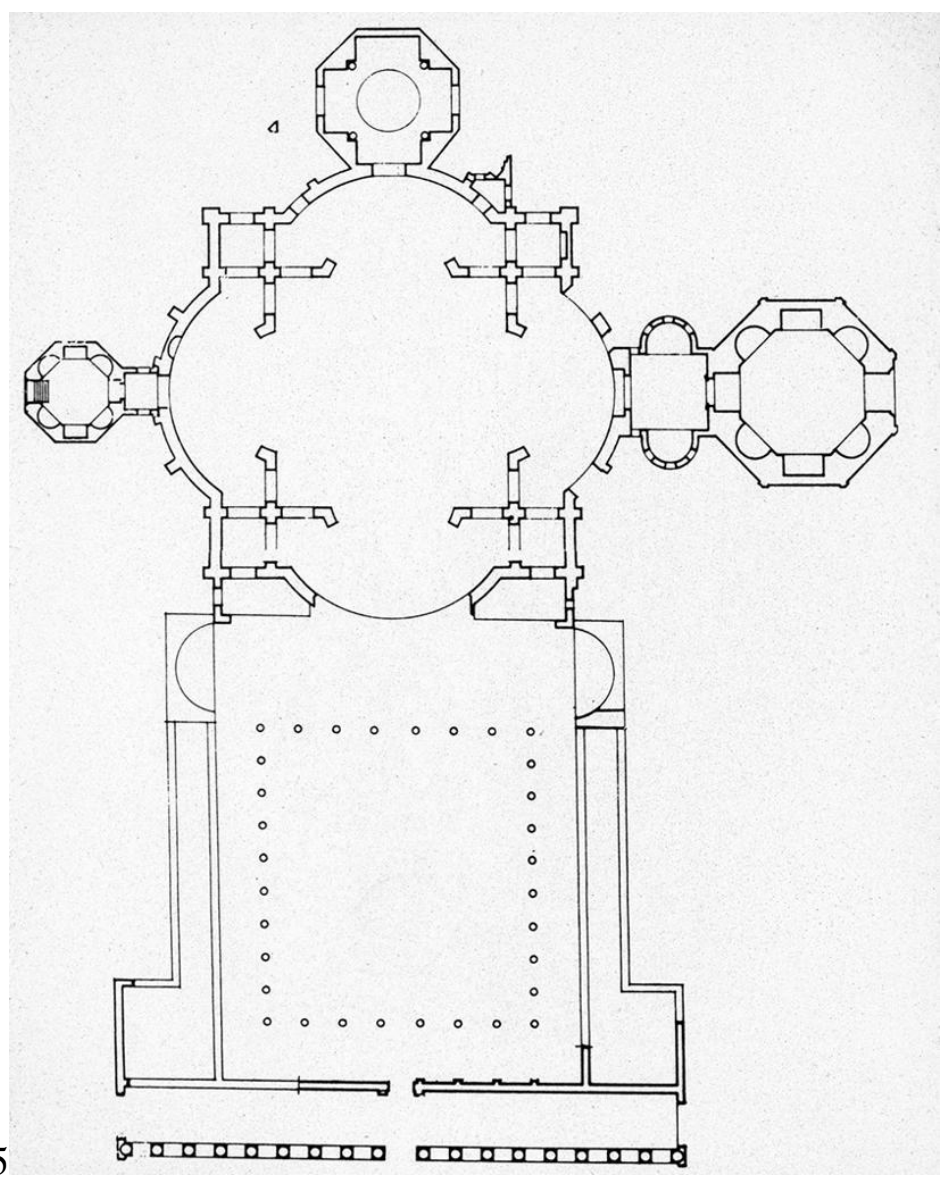

Fig. 15

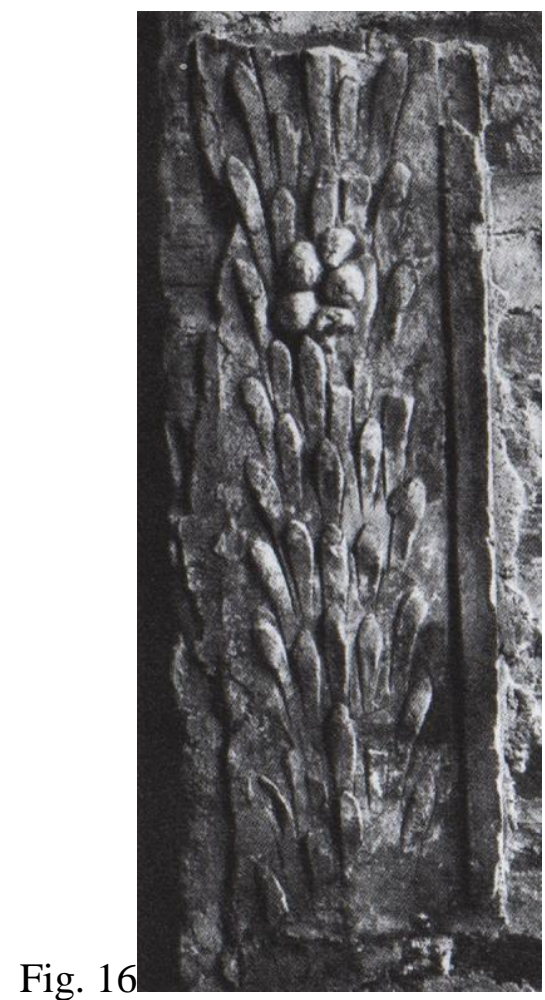




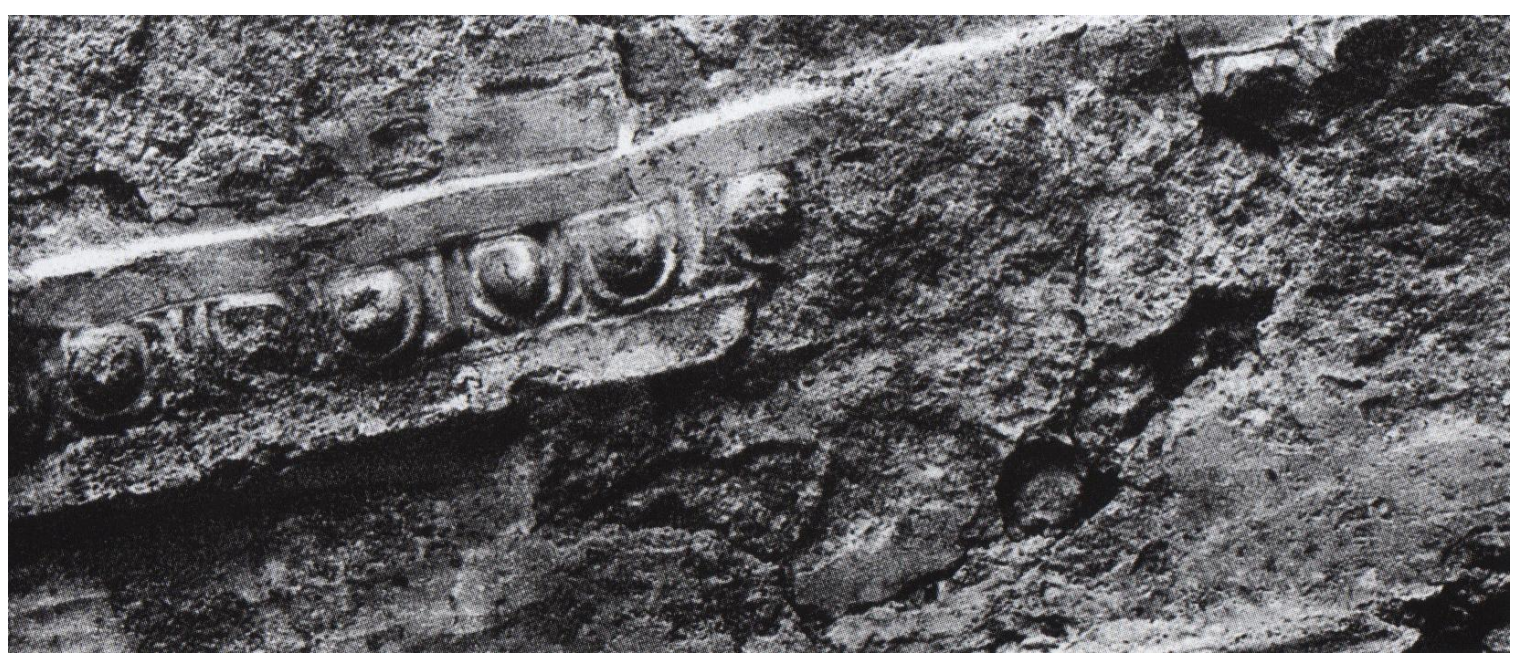

Fig. 17

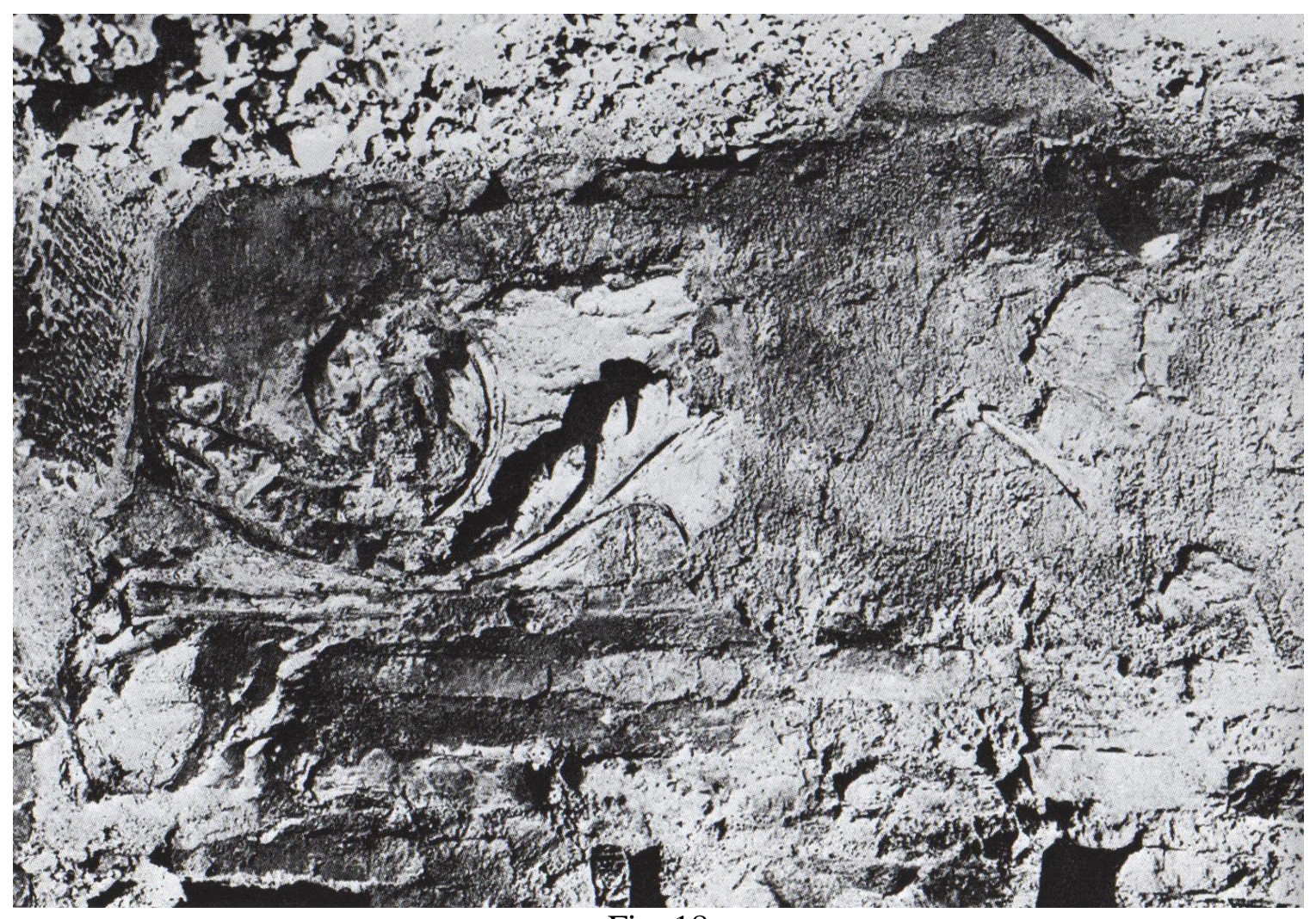

Fig. 18 


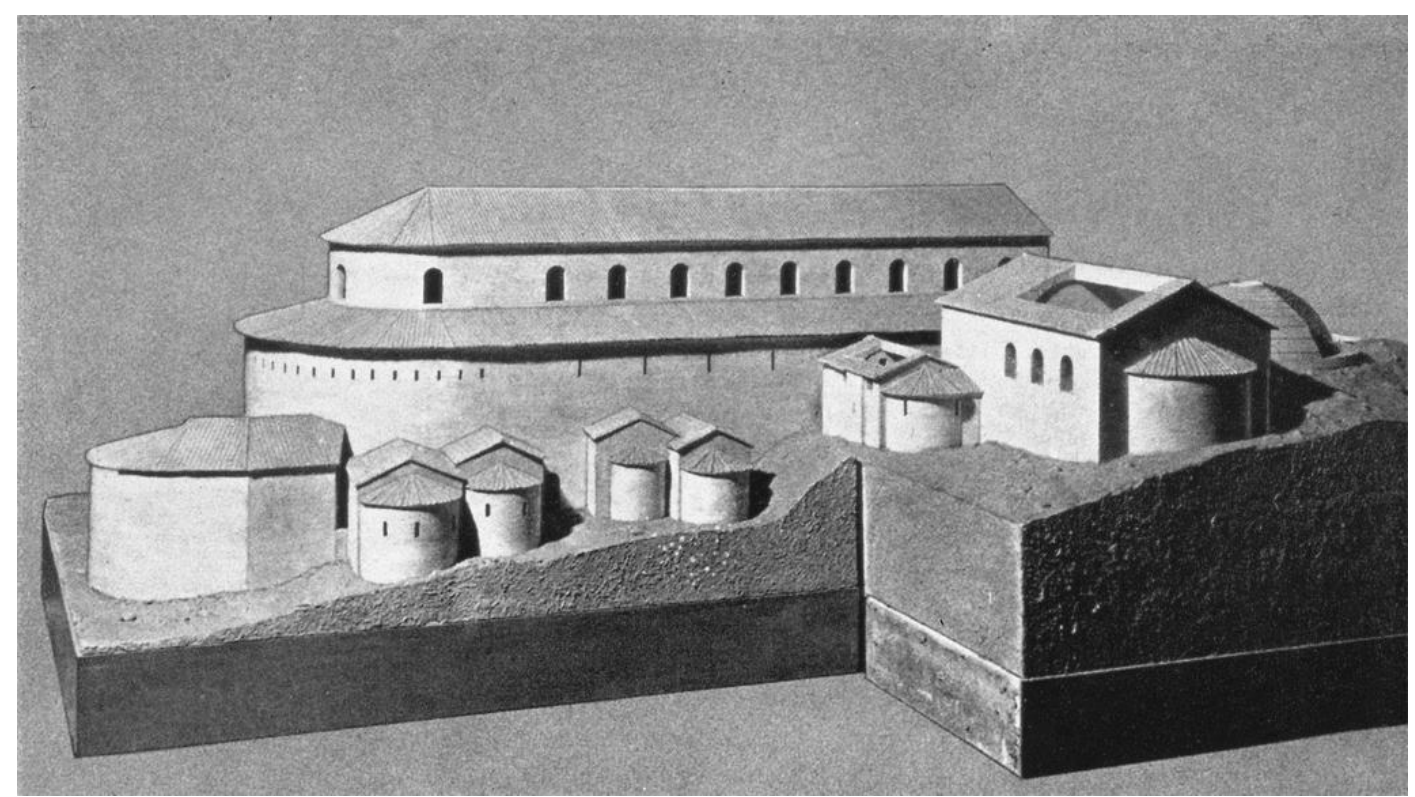

Fig. 19

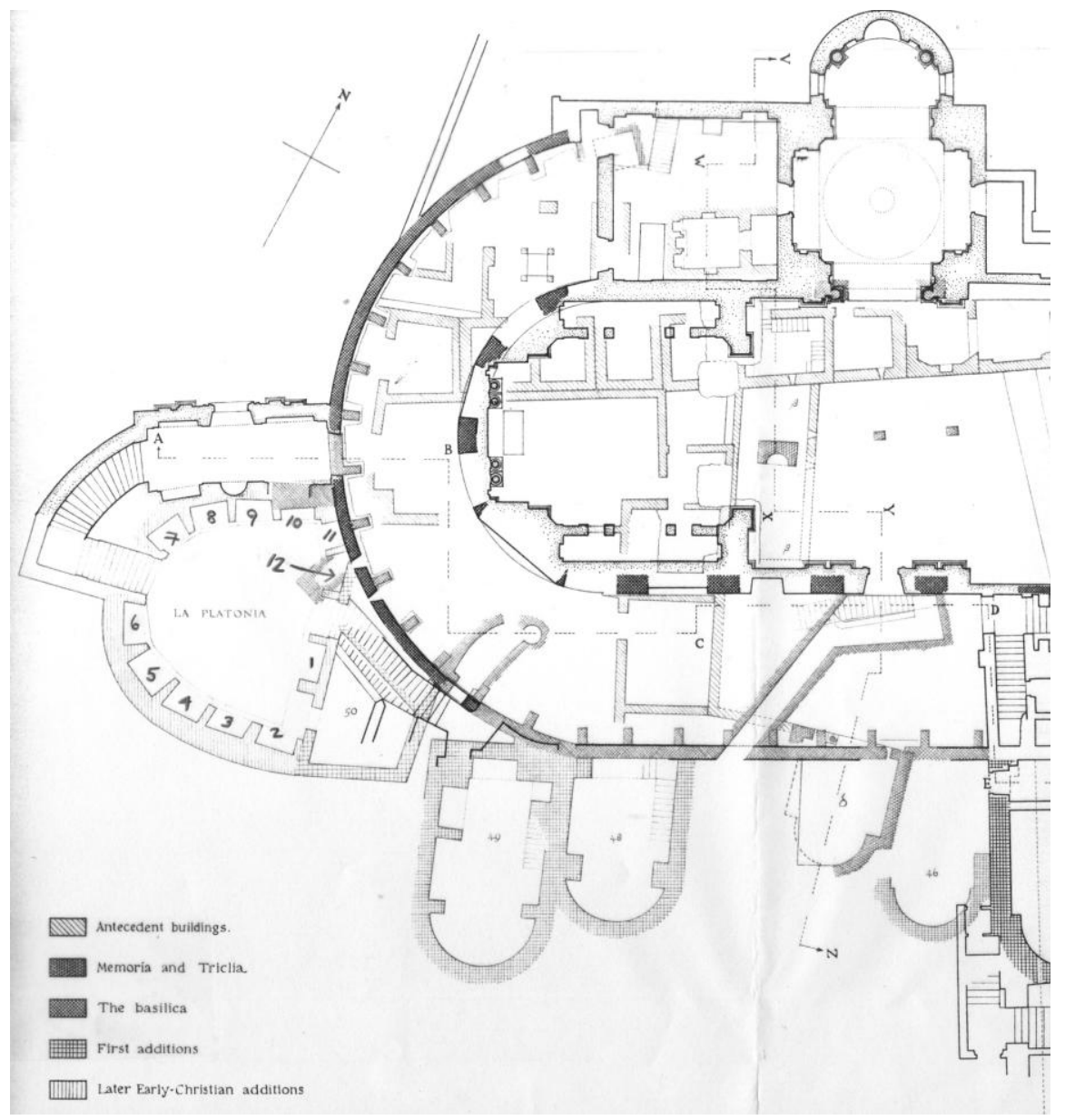

Fig. 20 


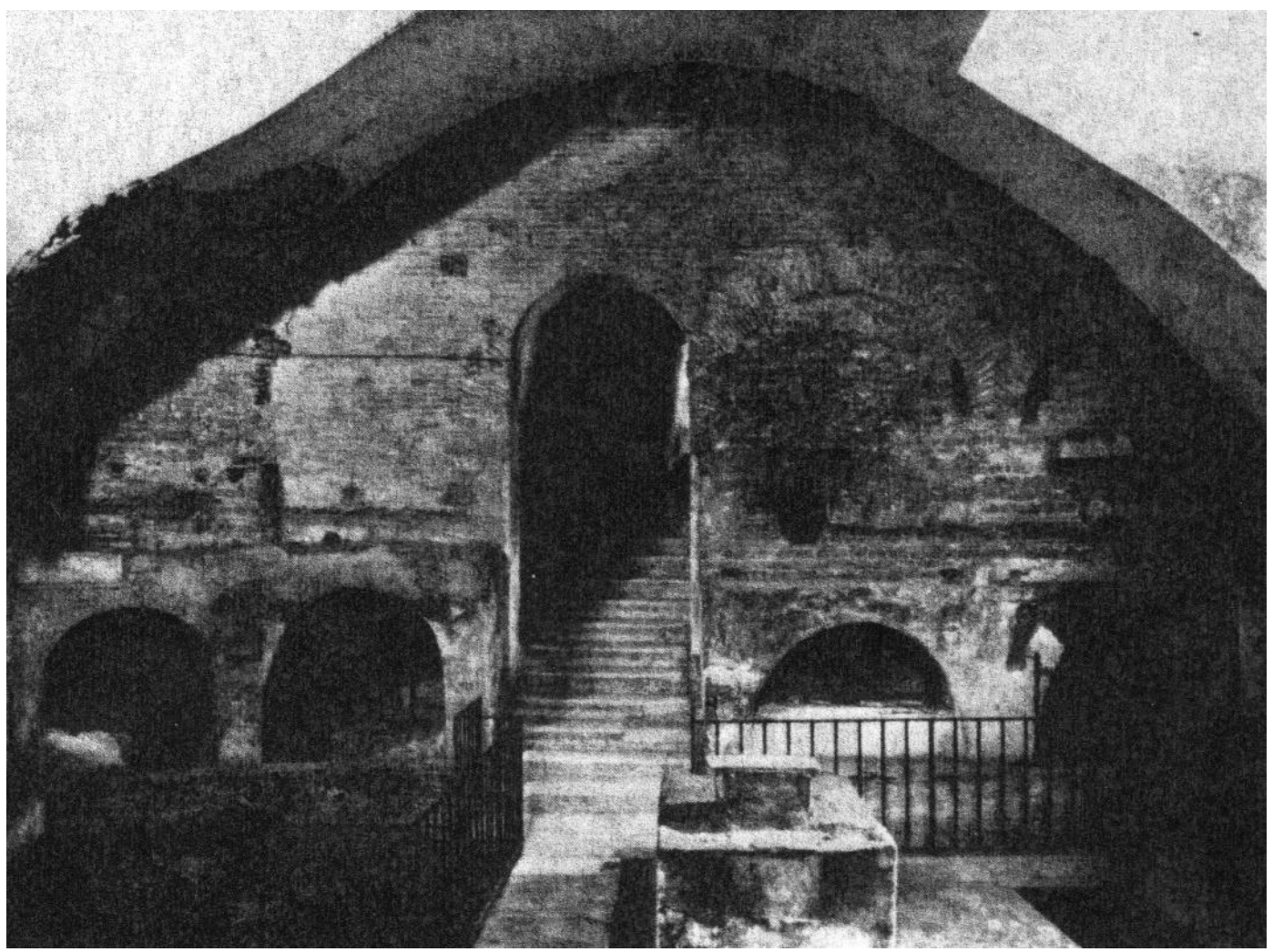

Fig. 21

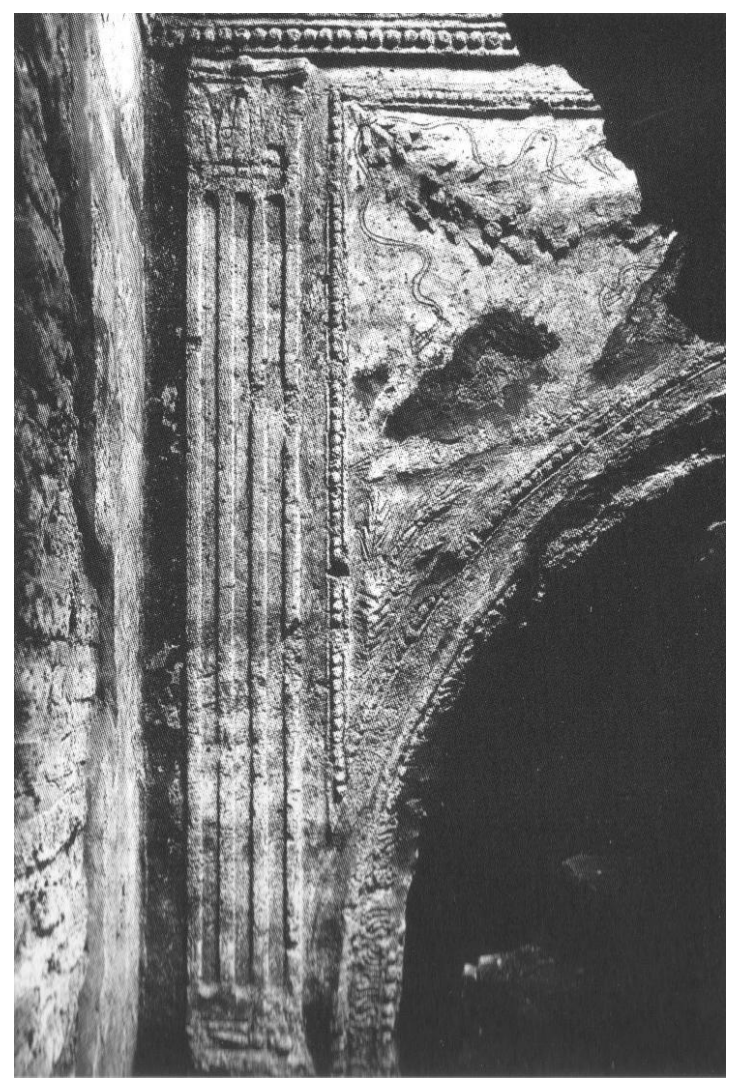

Fig. 22 


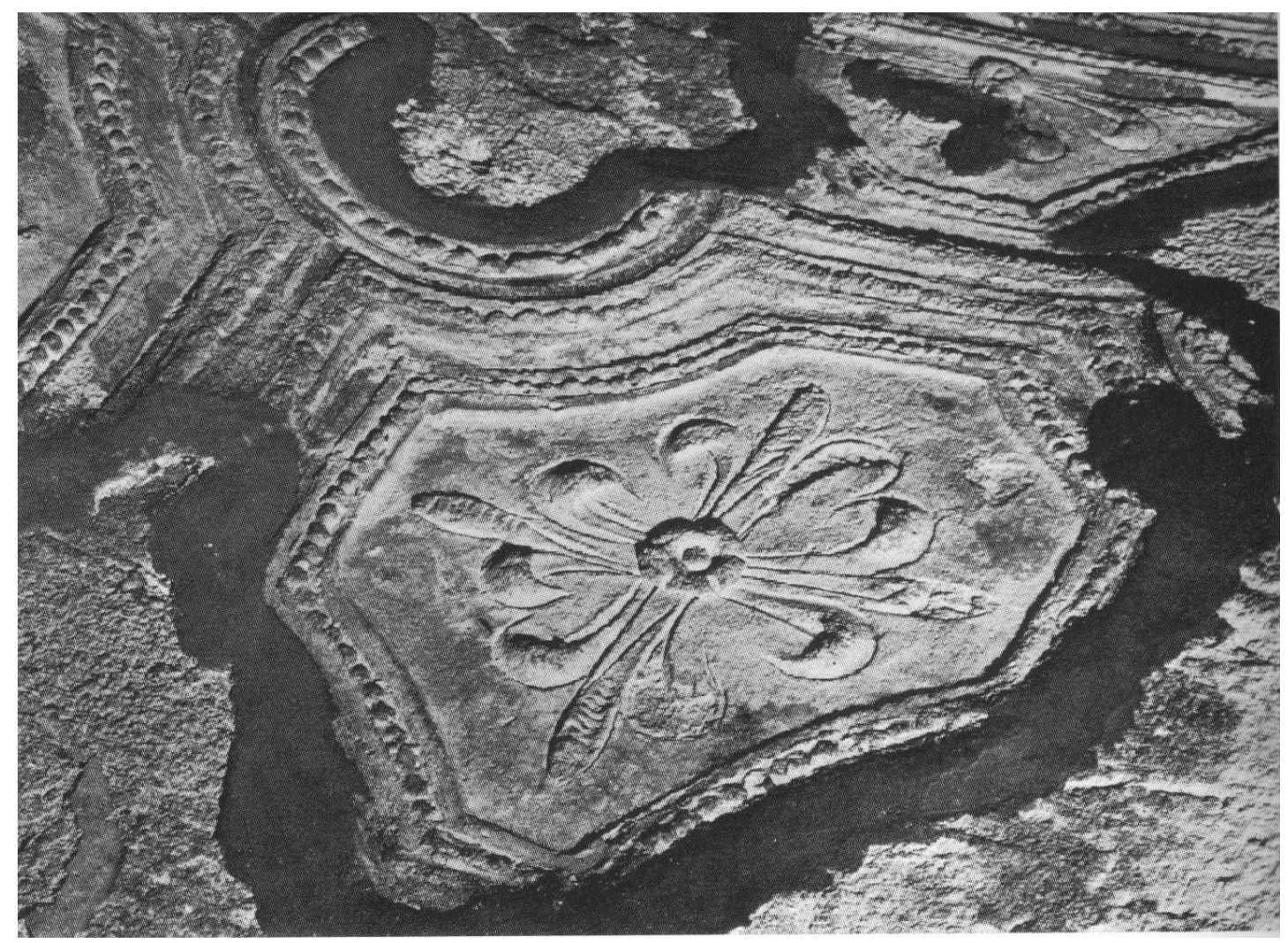

Fig. 23

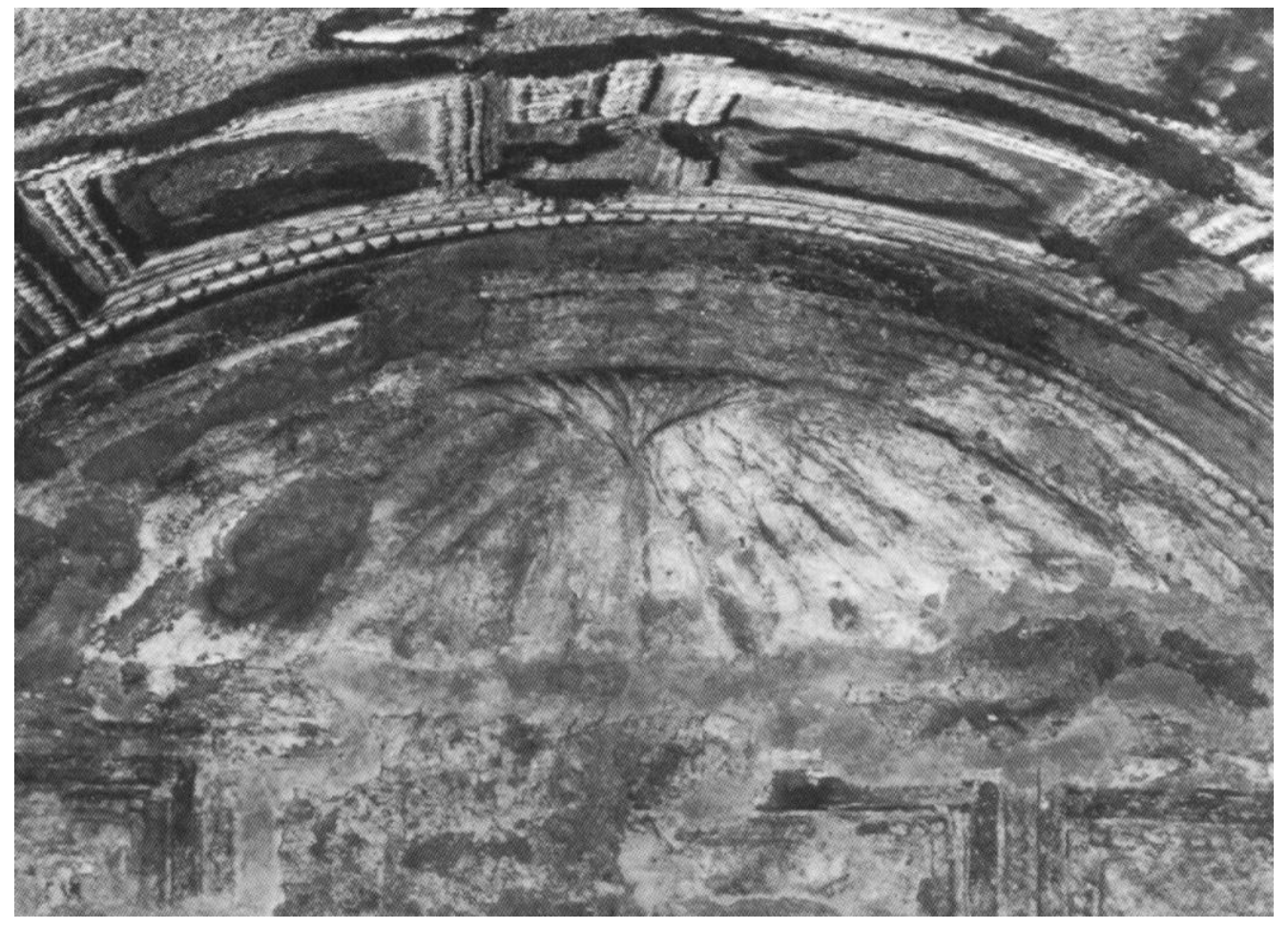

Fig. 24 


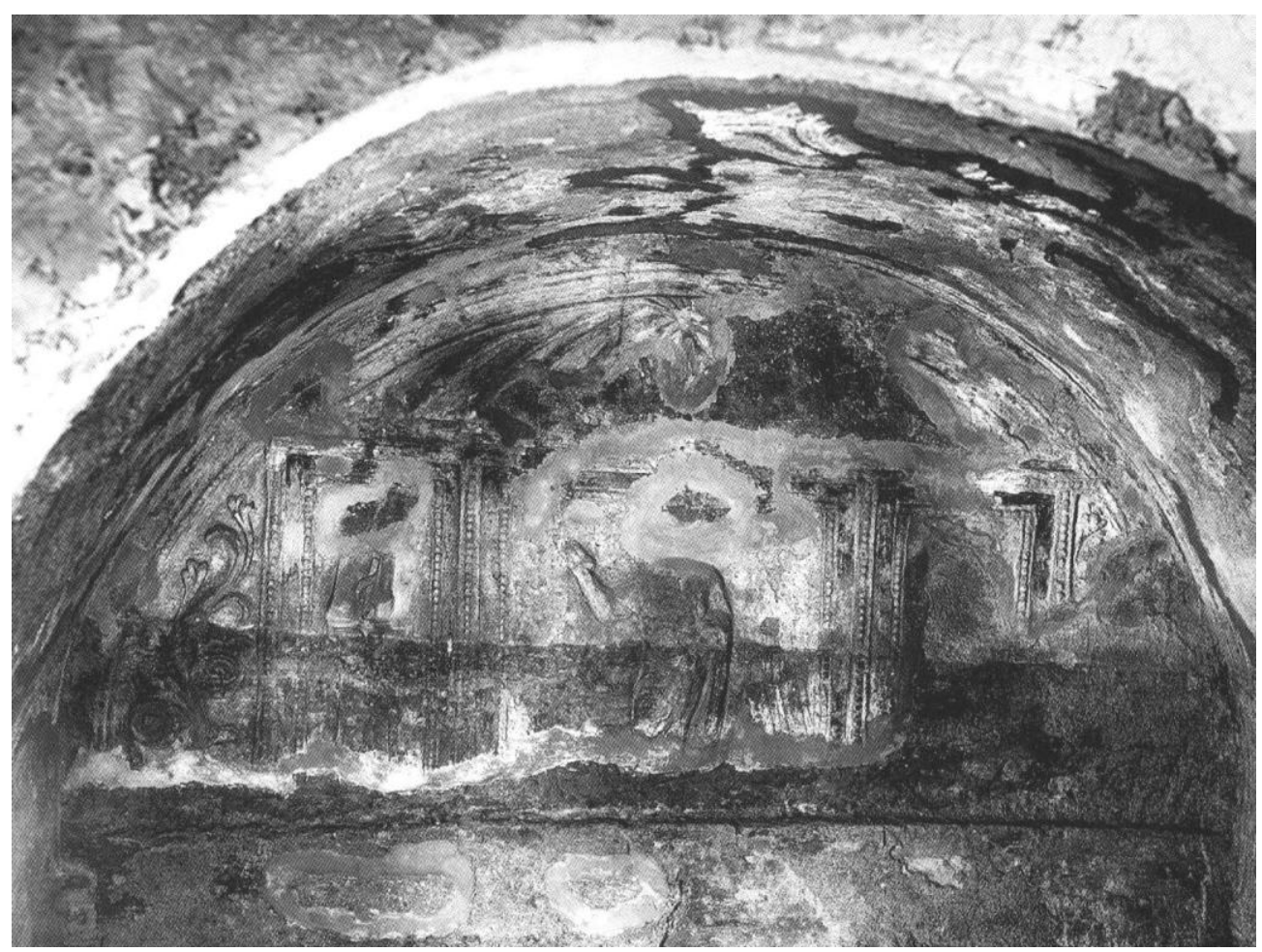

Fig. 25

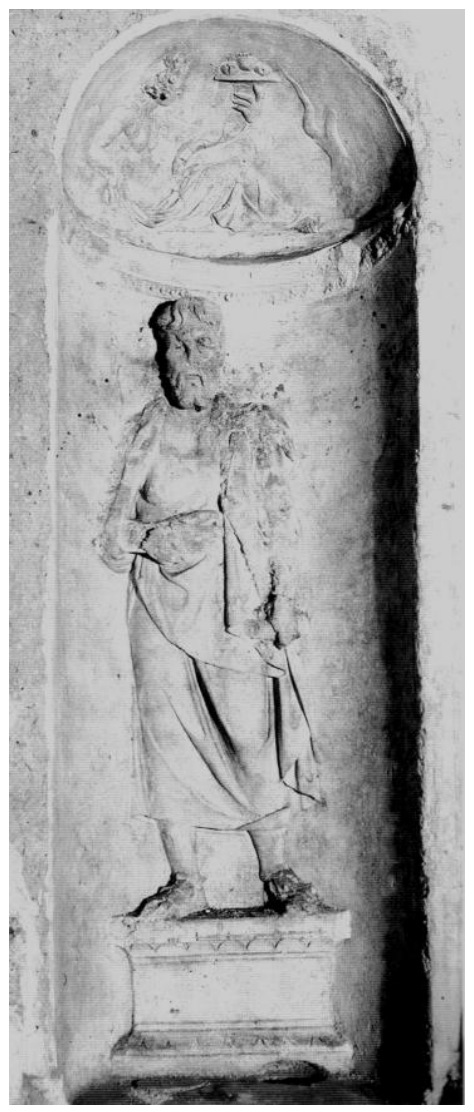

Fig. 26 


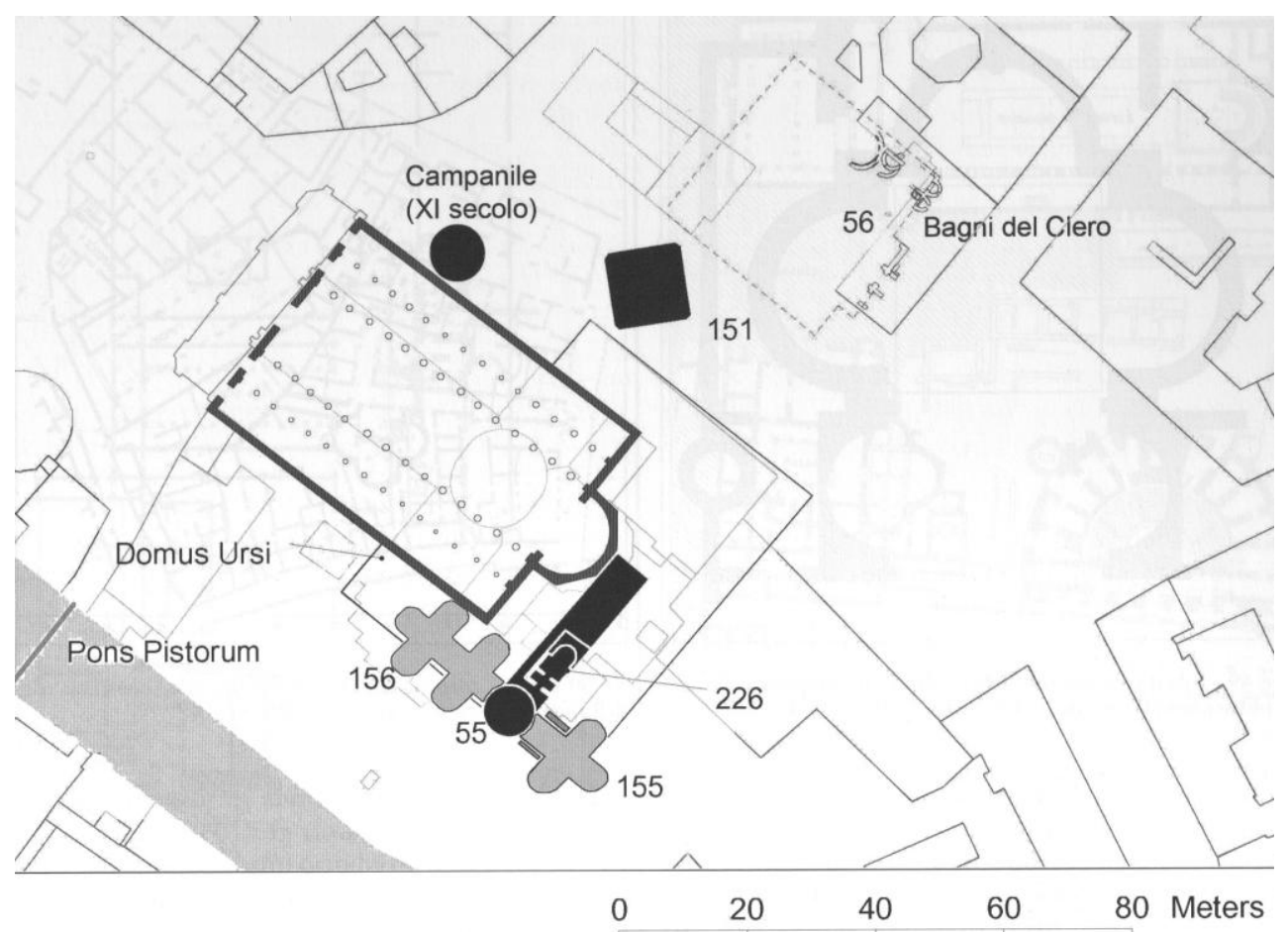

Complesso episcopale (schema ricostruttivo):

55 = Torre Salustra; 56 = Bagni del Clero; 151 = Battistero Neoniano; 155 = Tricoli; 156 = Quinque accubita

Episcopio

Strutture ipotetiche

Area dell'episcopio

Strutture dell'episcopio conservate in elevato
Basilica Ursiana

Strutture della basilica Ursiana

desunte dai rilievi di Buonamici (XVIII sec.)

Fig. 27

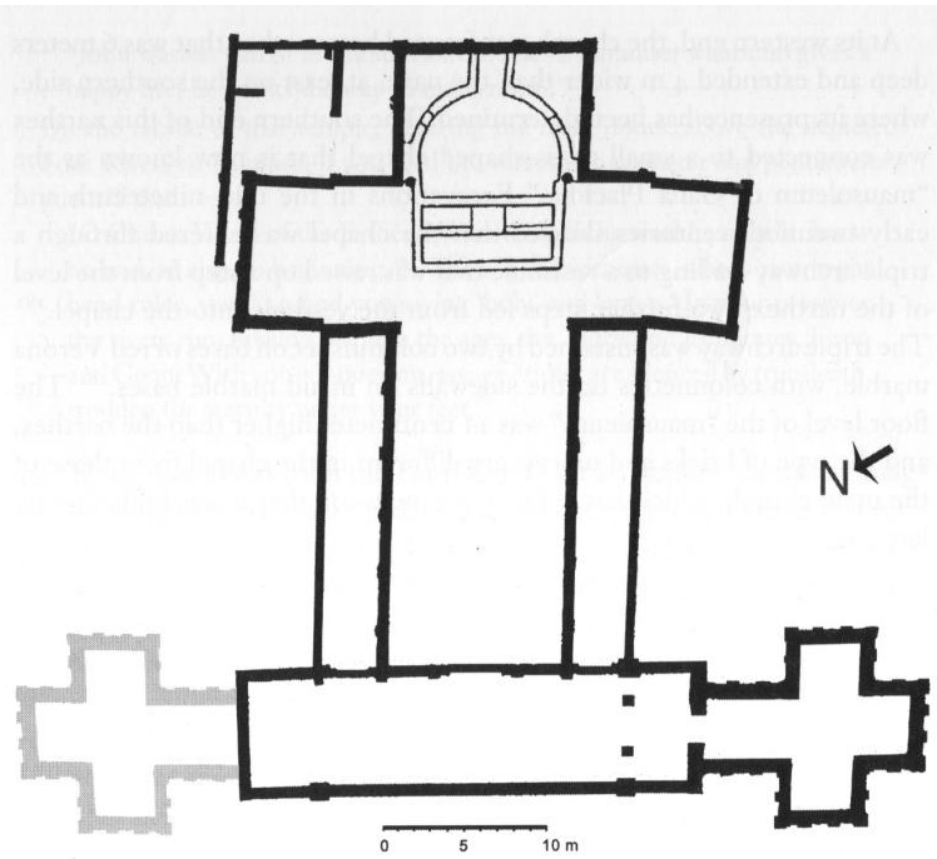

Fig. 28 


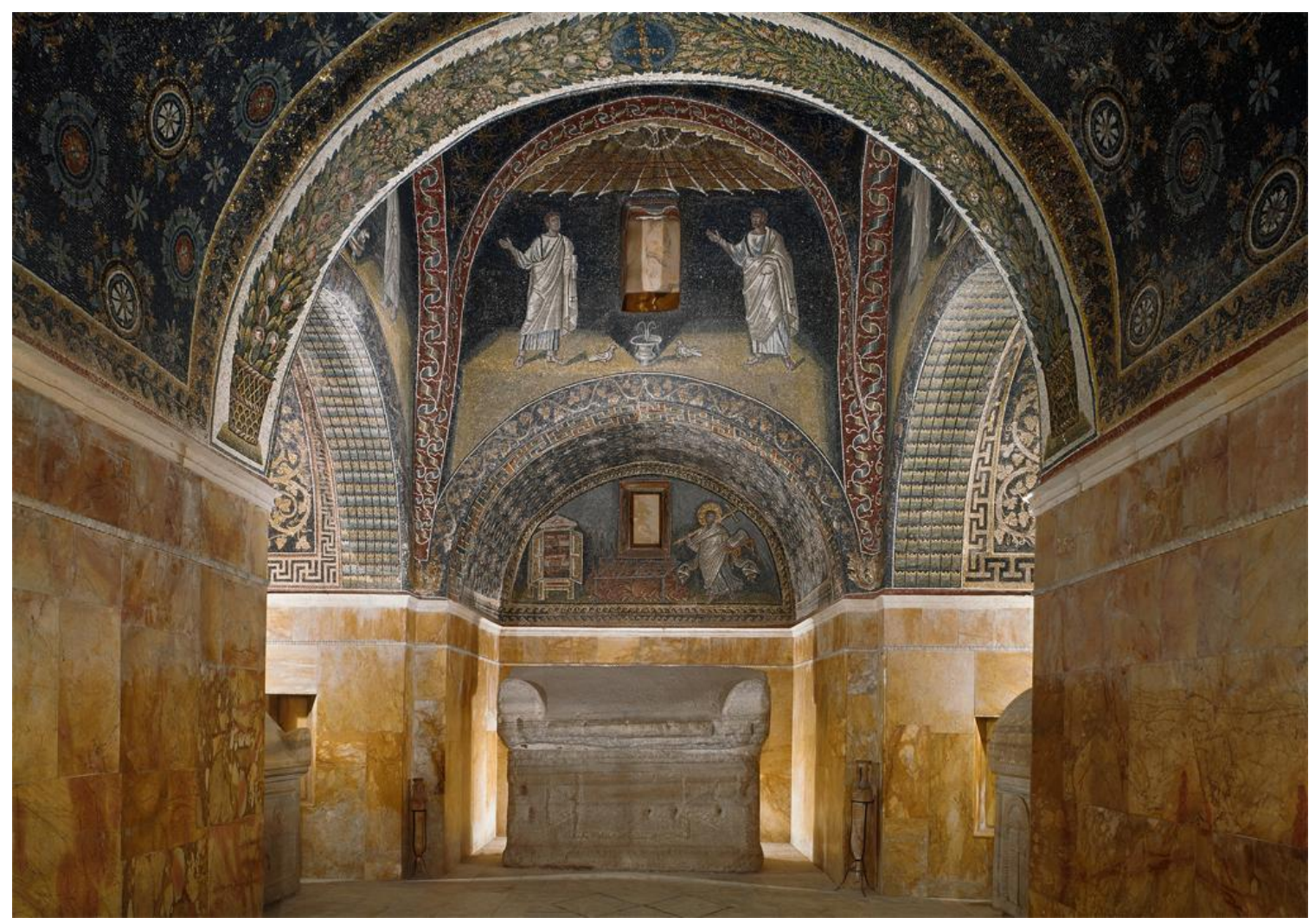

Fig. 29
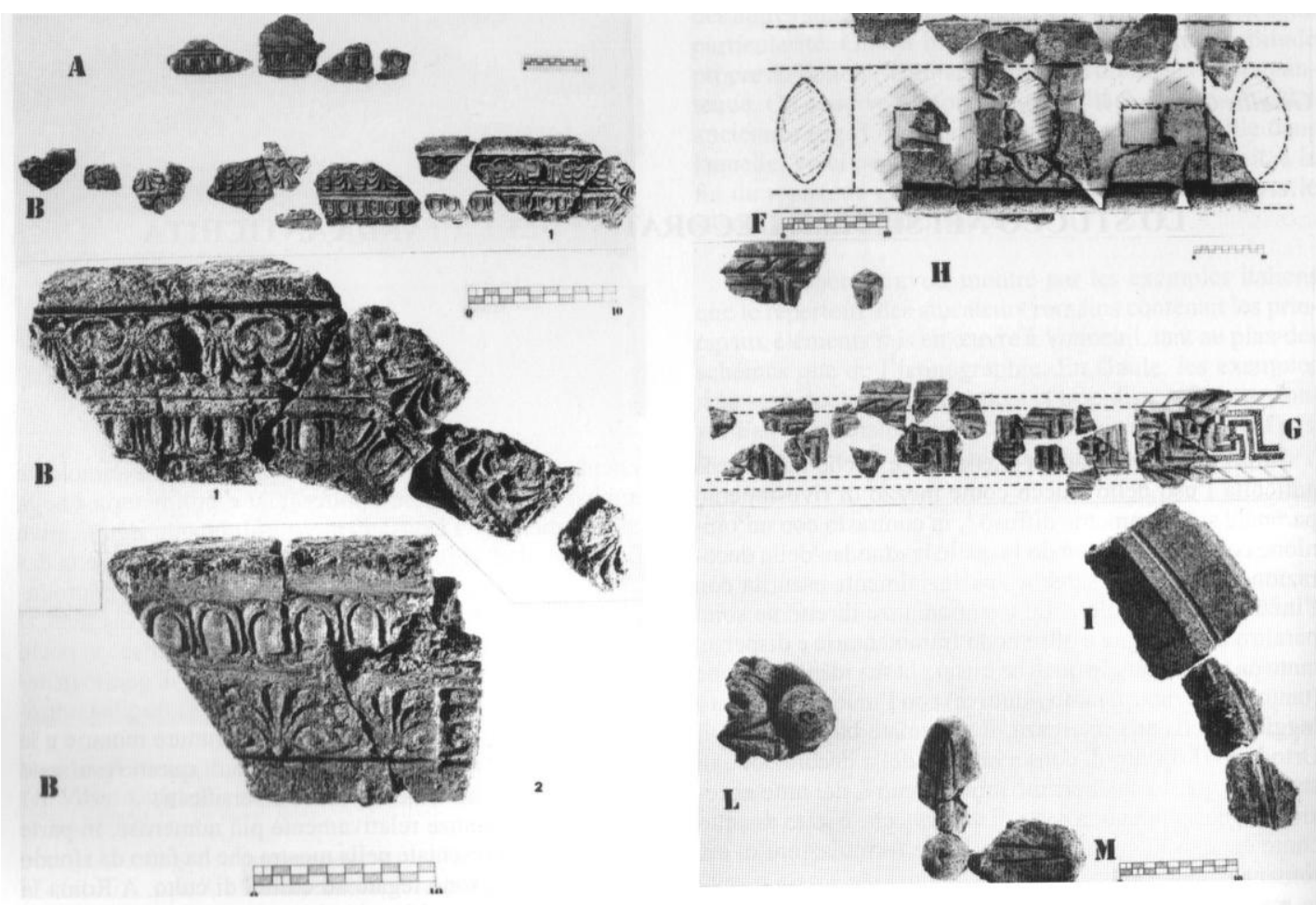

Fig. 30 


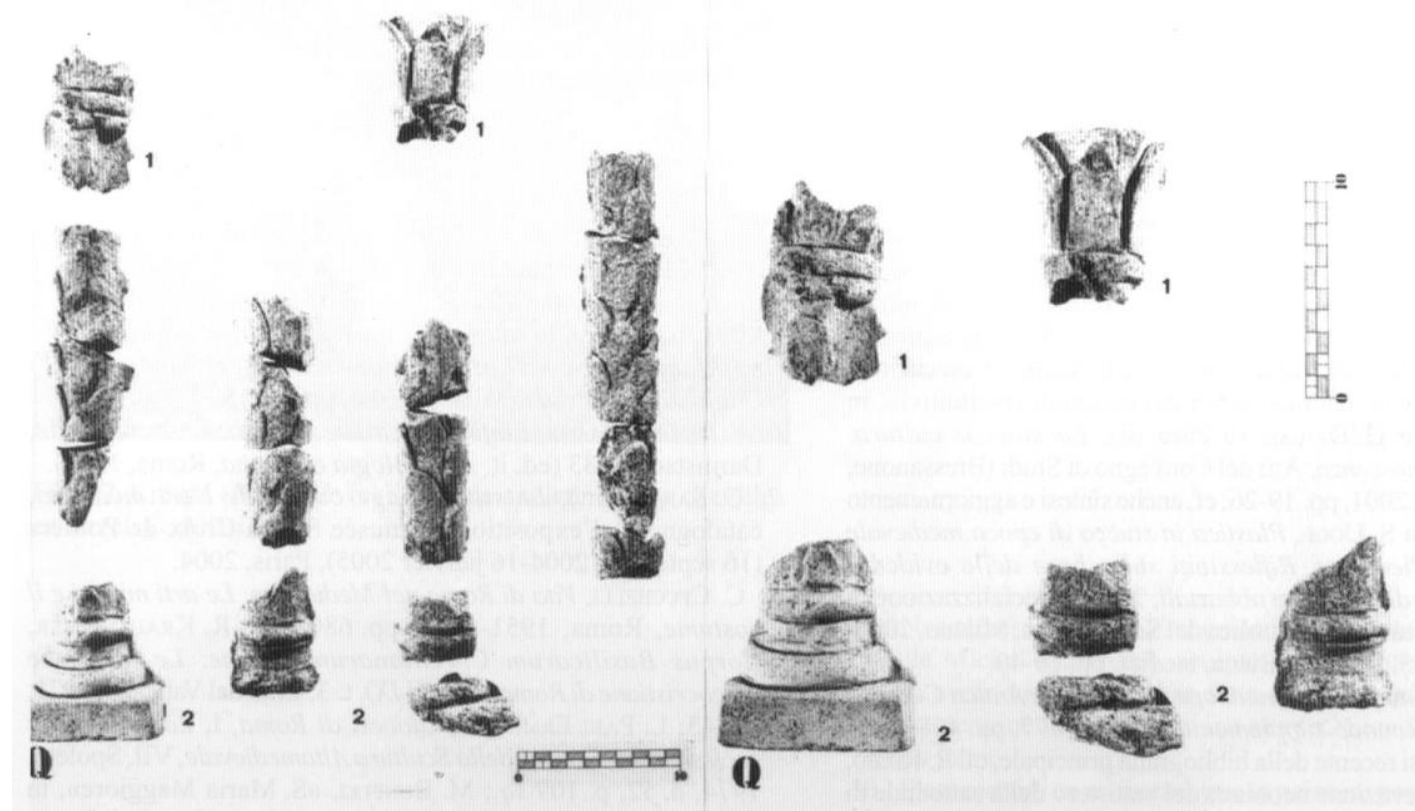

Fig. 31
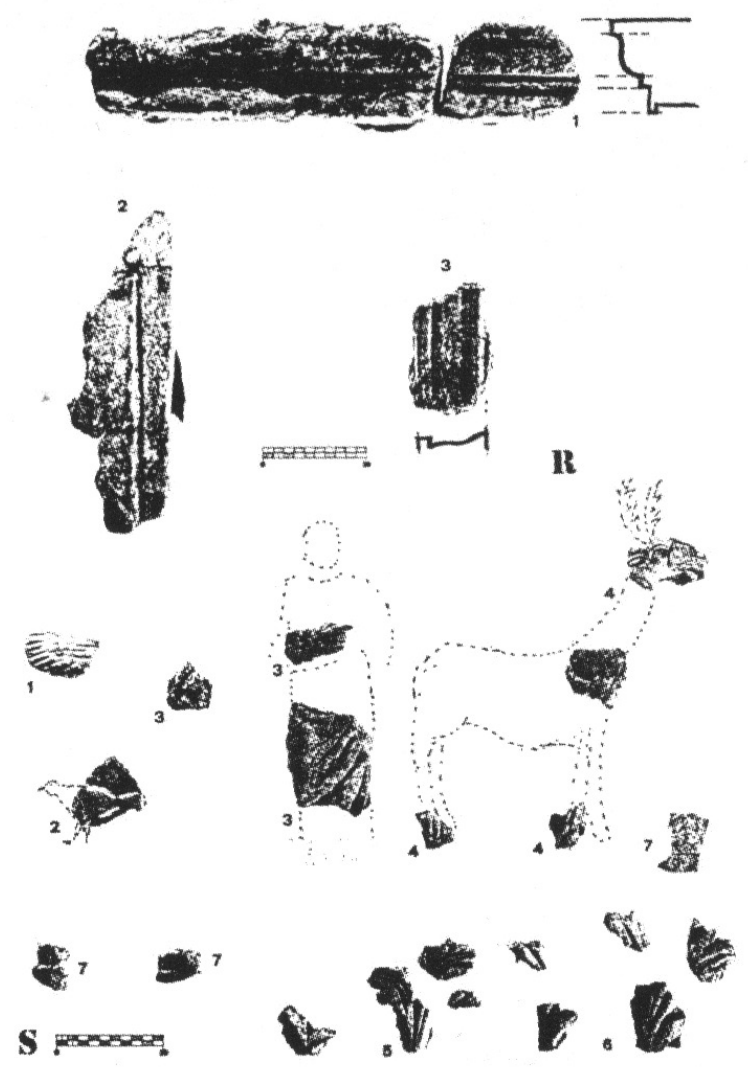

Fig. 32 

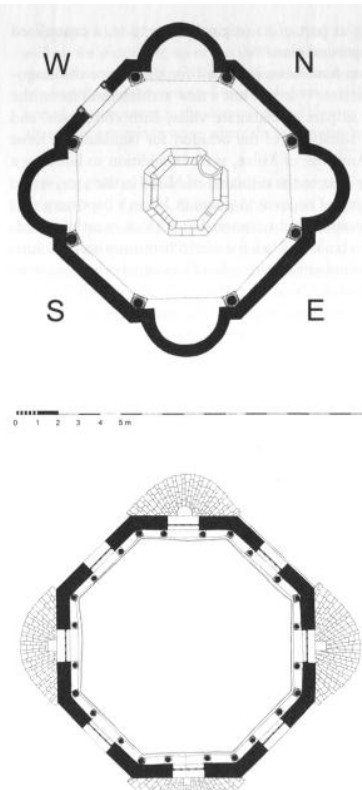

Fig. 33

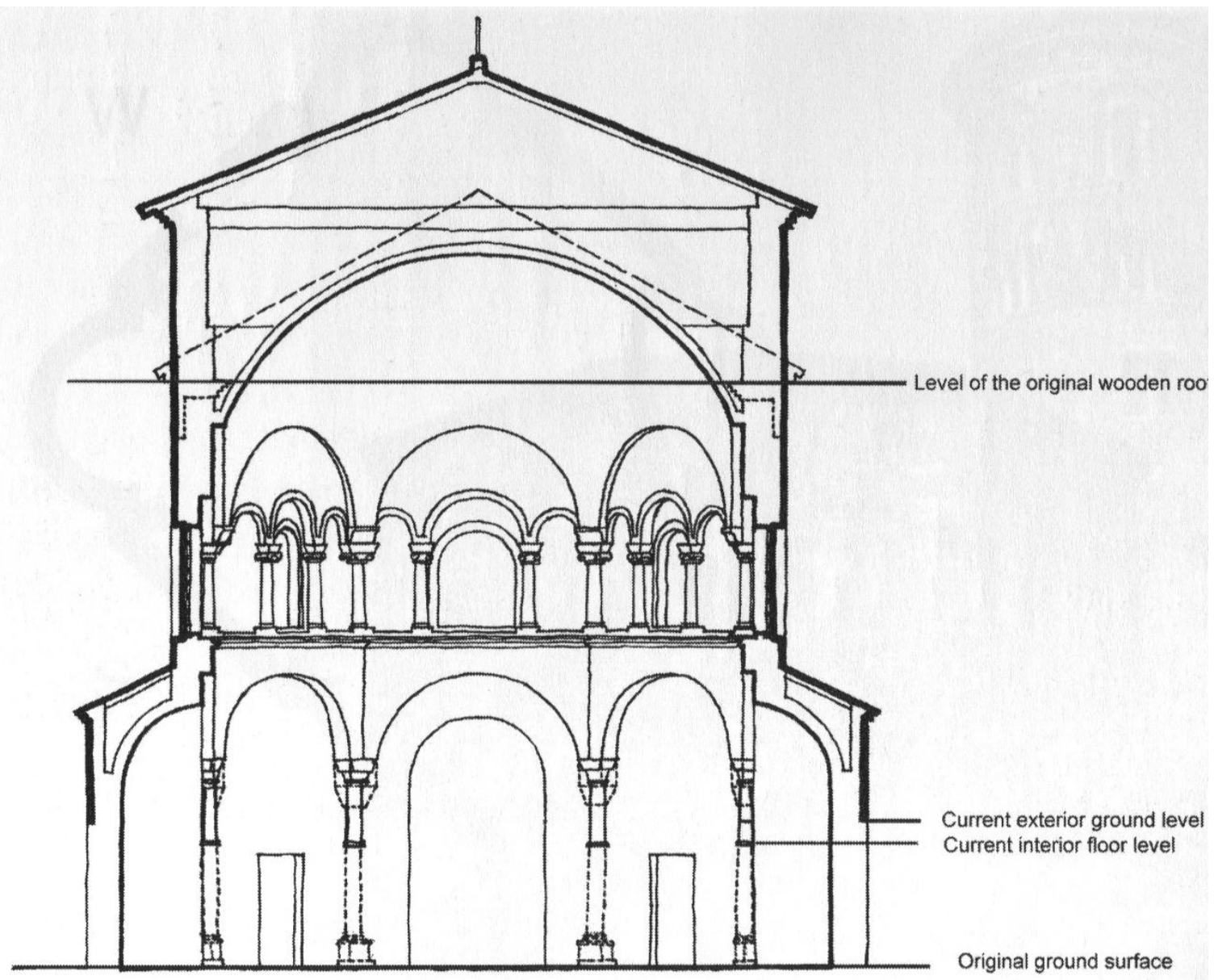

Fig. 34 


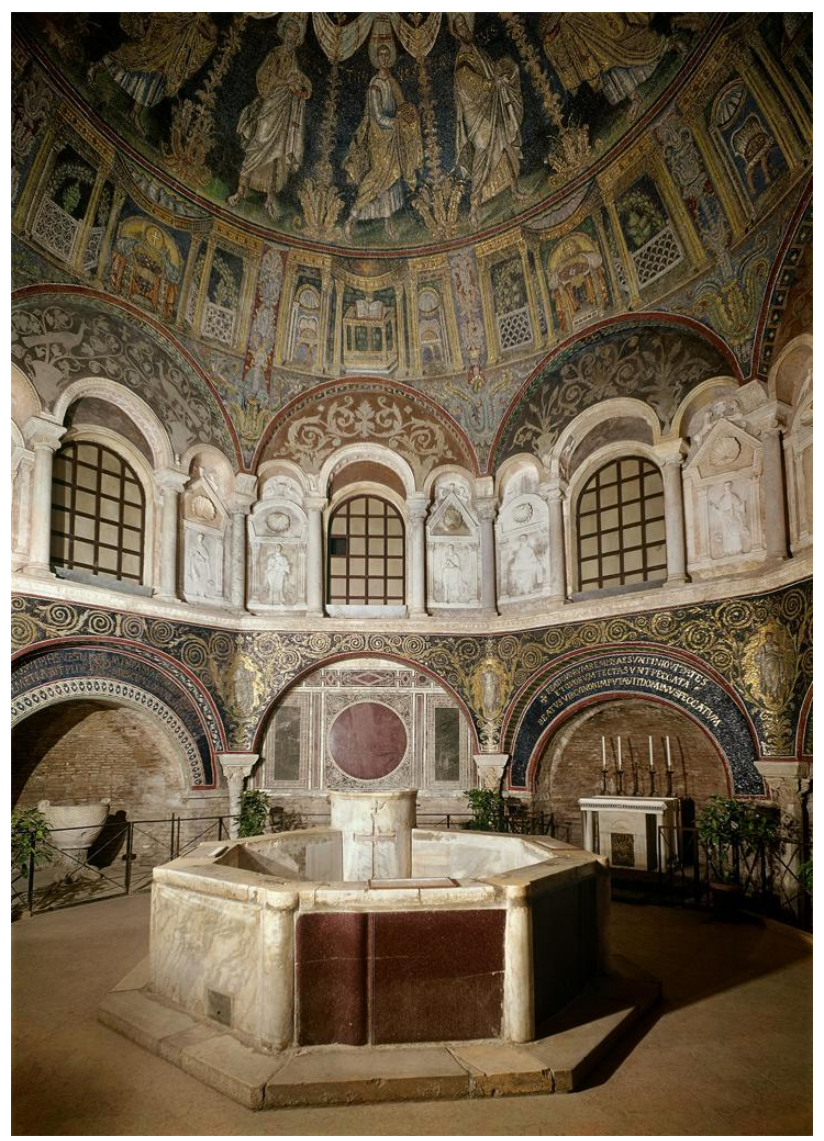

Fig. 35

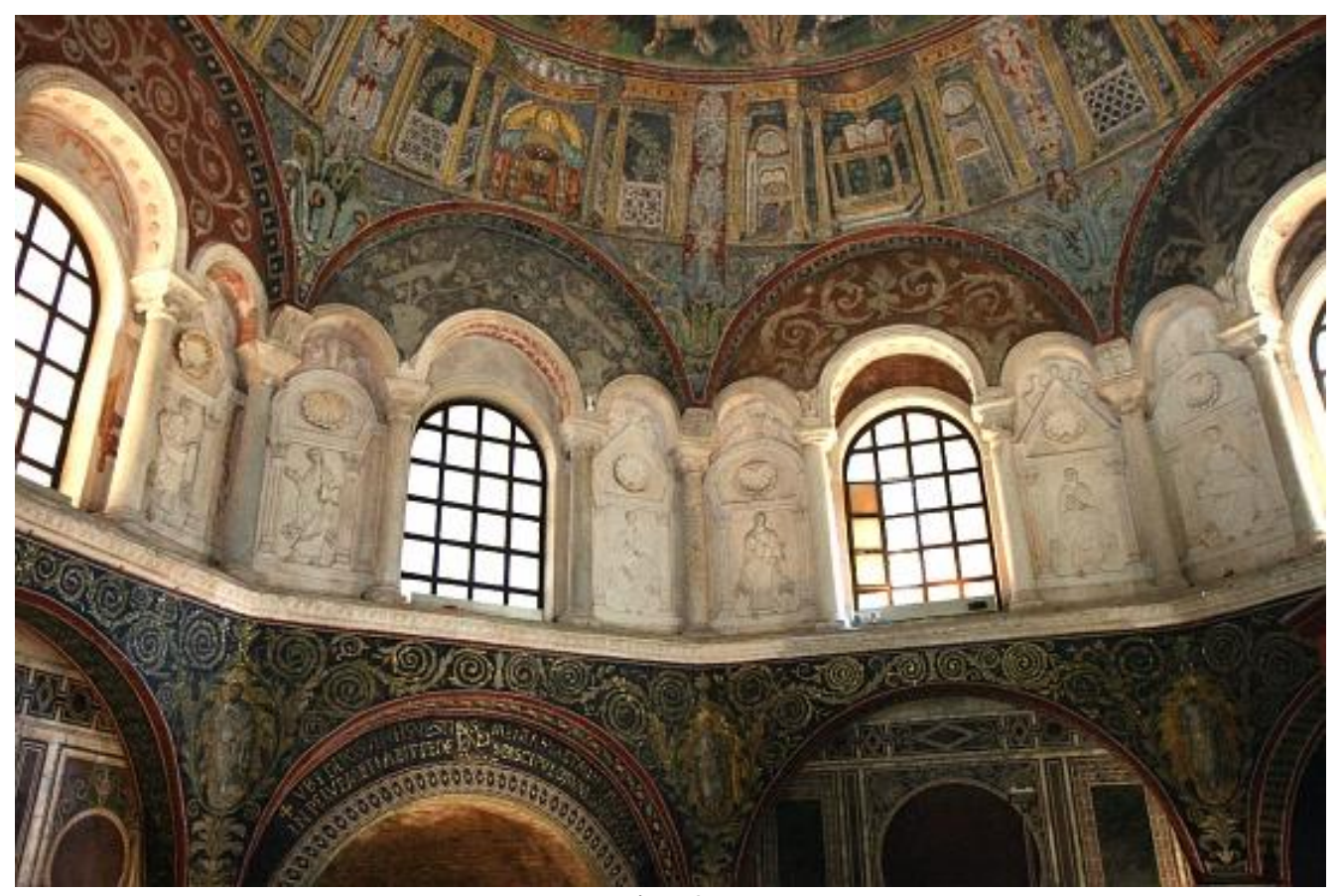

Fig. 36 


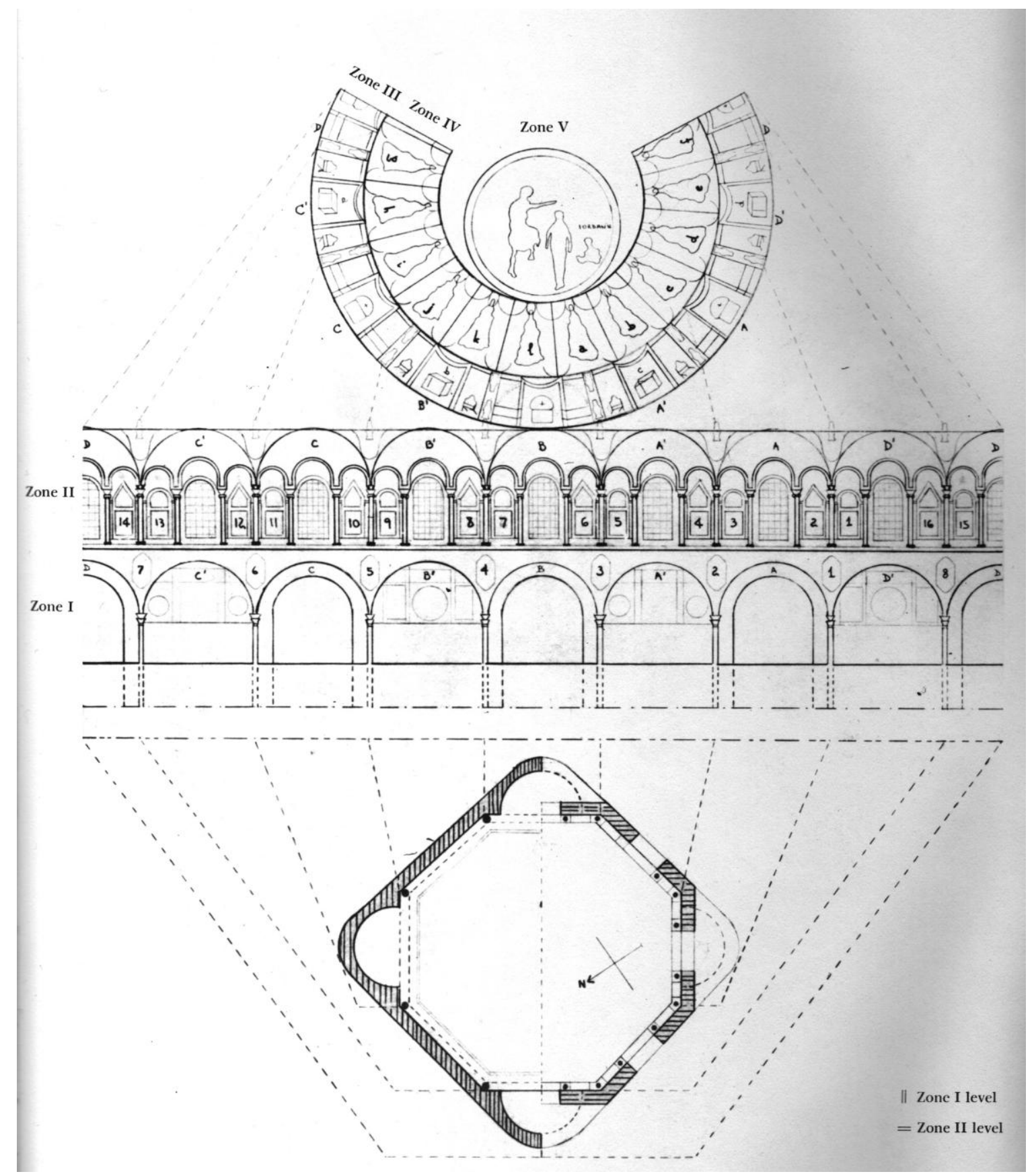

Fig. 37 


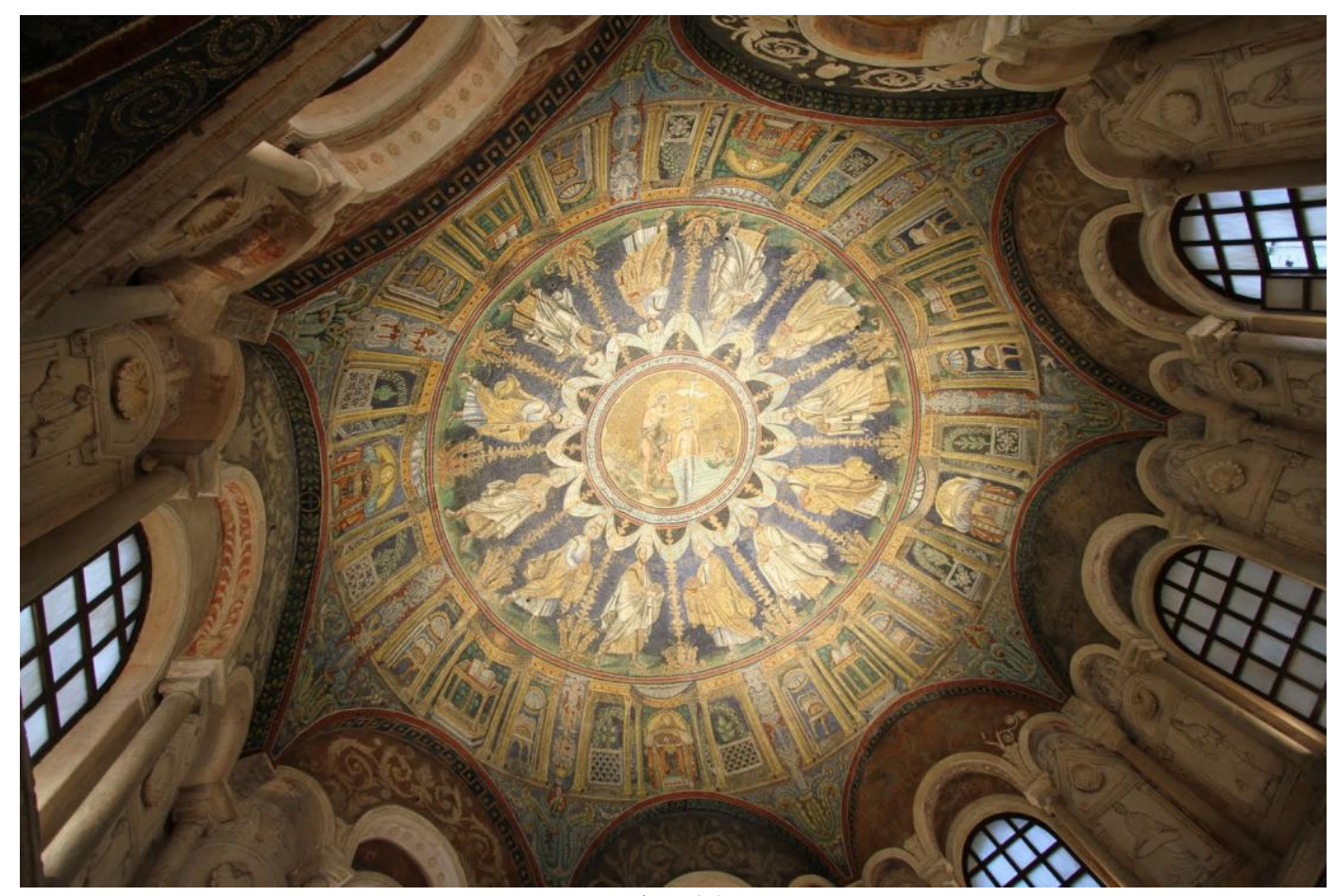

Fig. 38

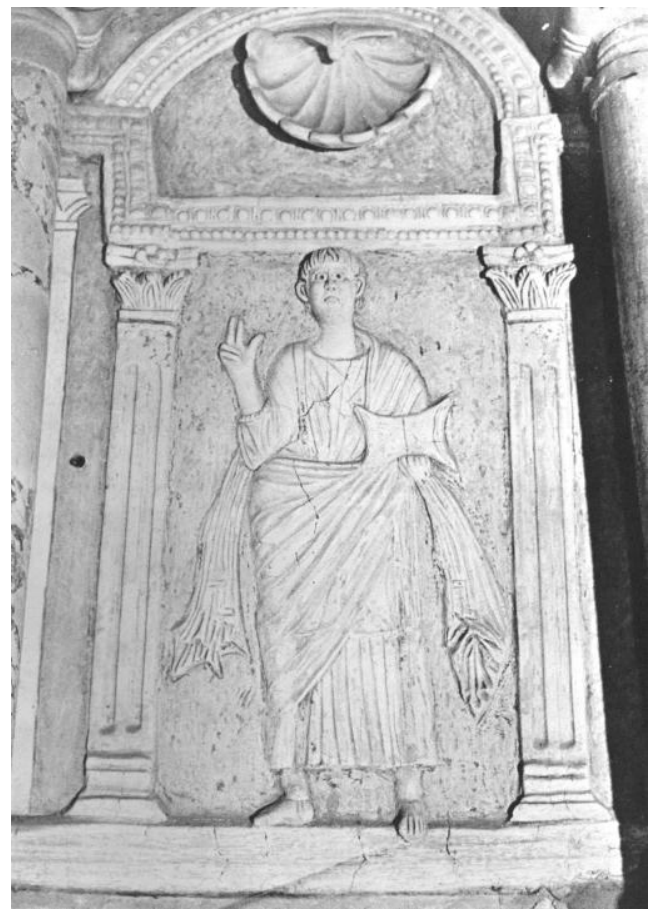

Fig. 39 (Niche 1)

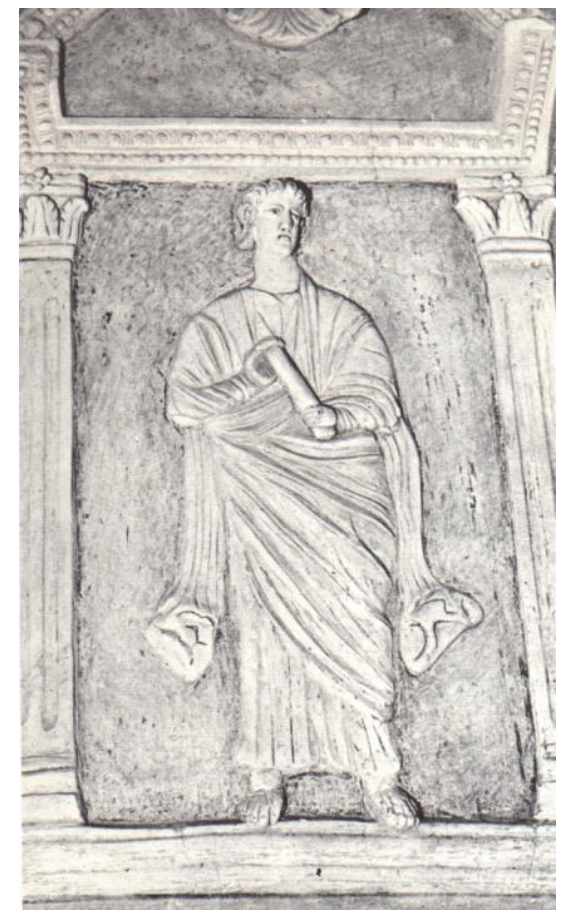

Fig. 40 (Niche 2) 


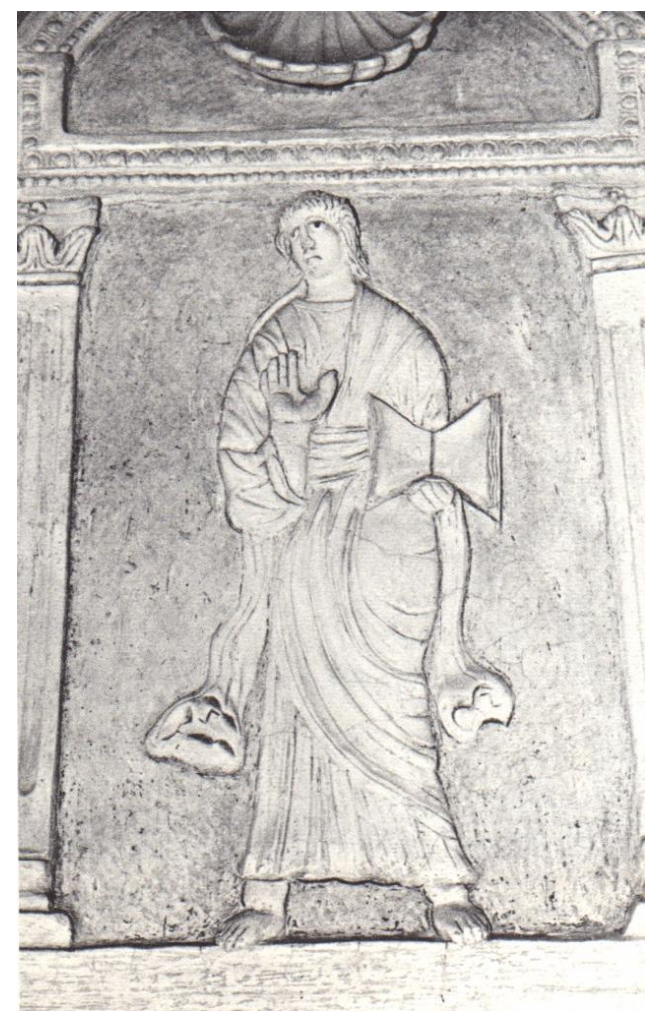

Fig. 41 (Niche 3)

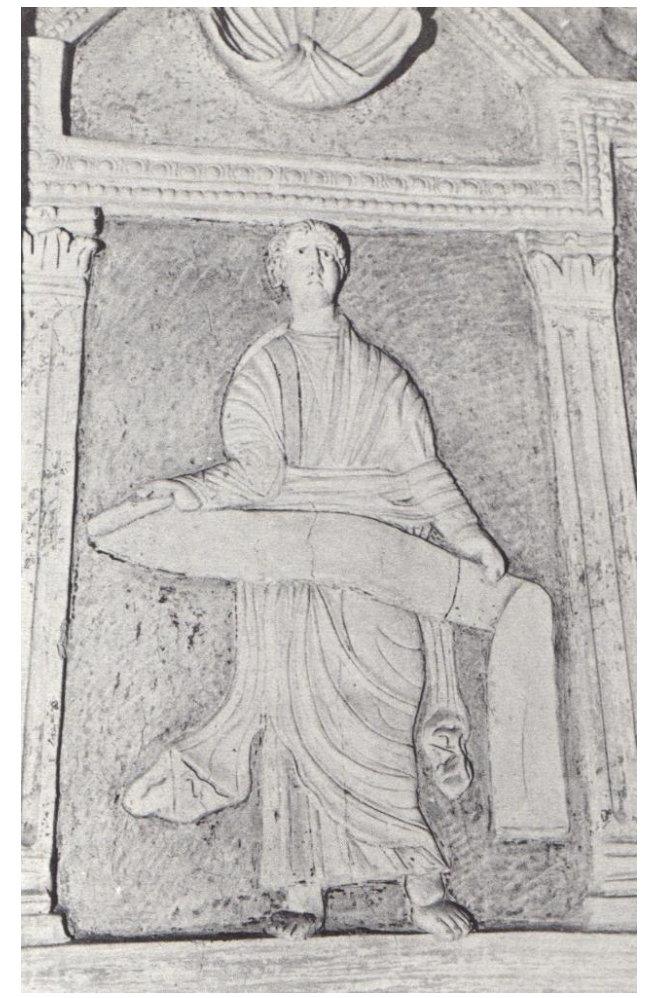

Fig. 42 (Niche 4)

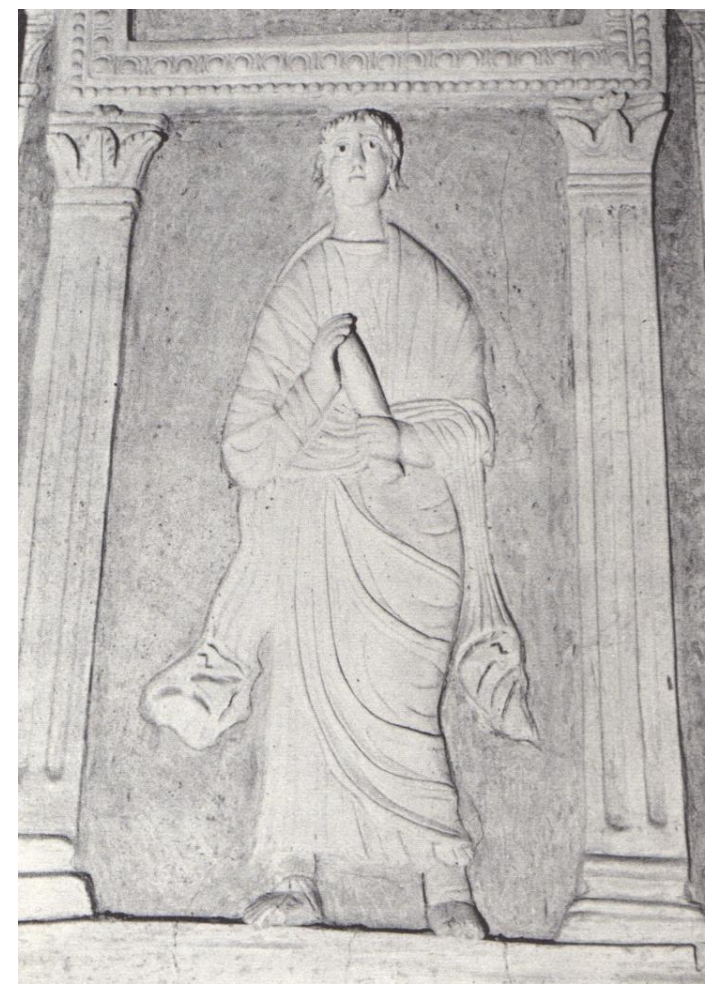

Fig. 43 (Niche 5)

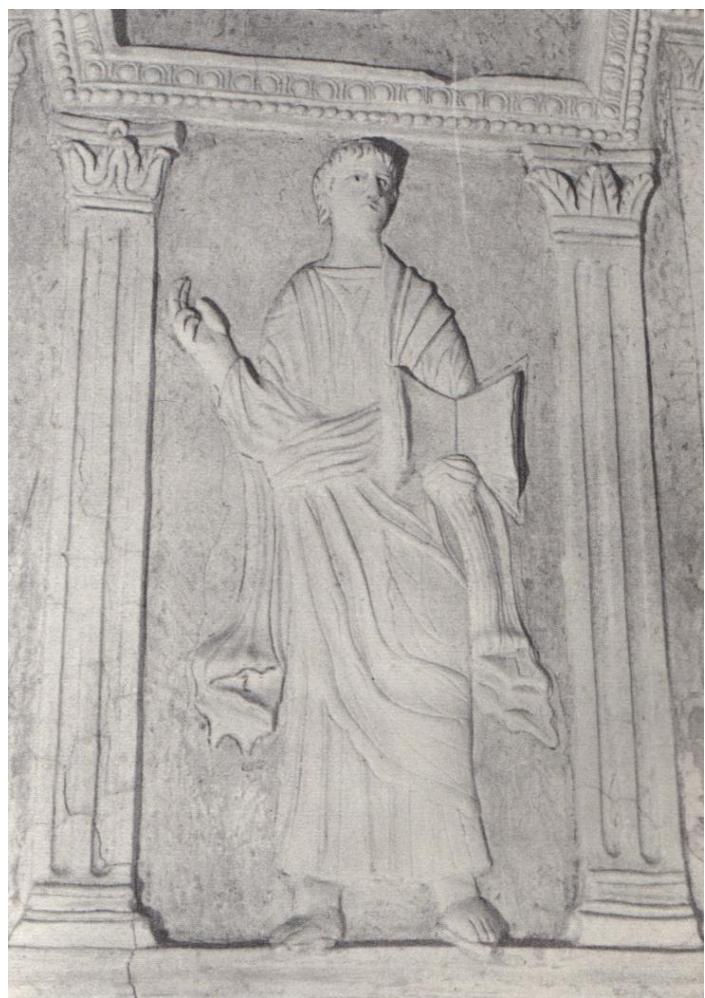

Fig. 44 (Niche 6) 


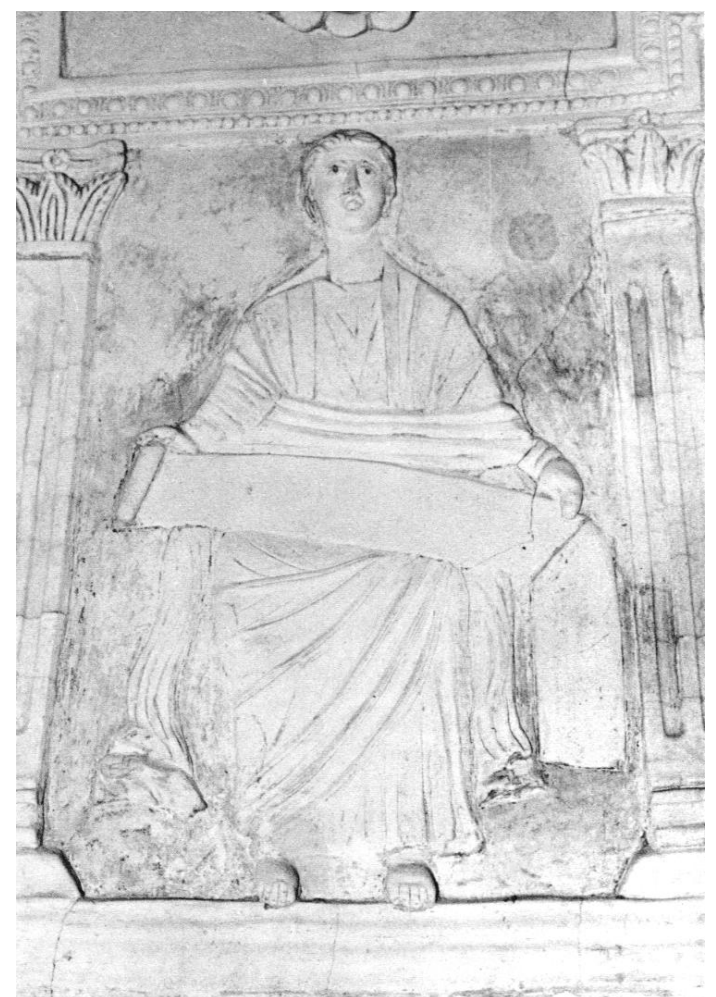

Fig. 45 (Niche 7)

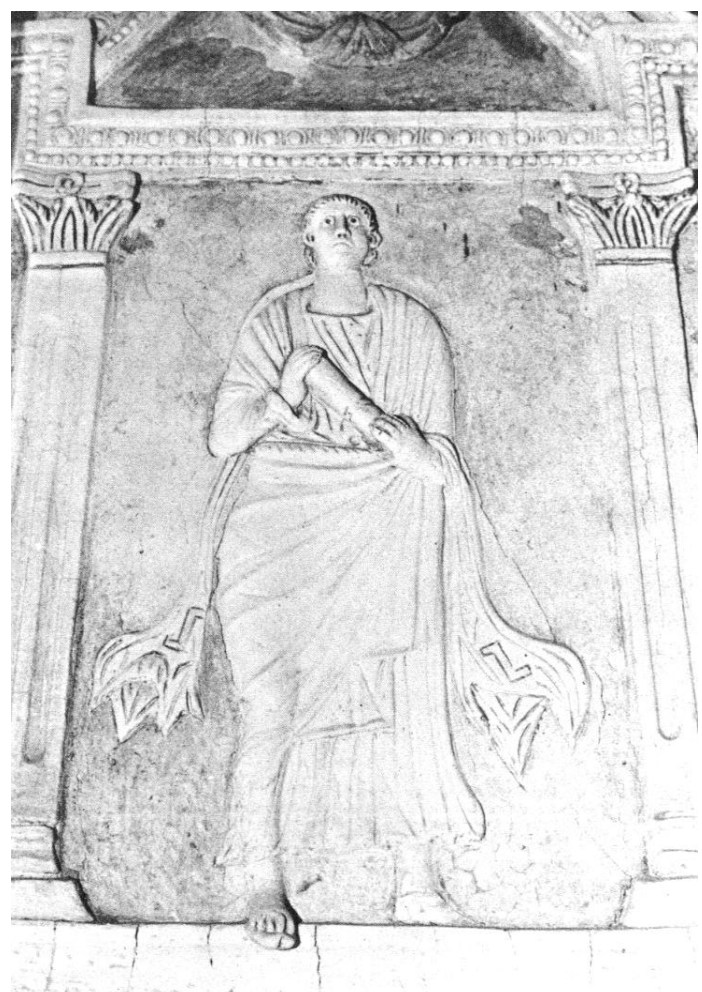

Fig. 46 (Niche 8)

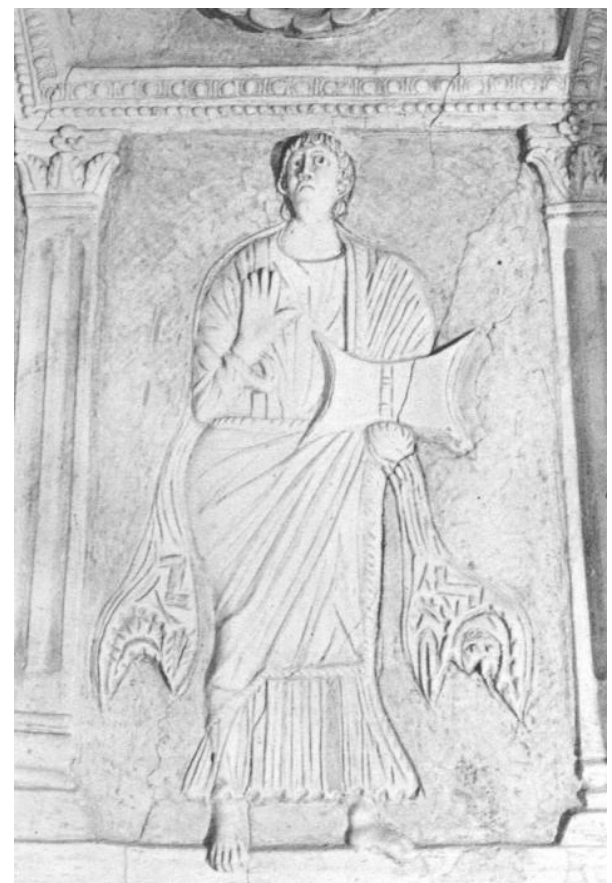

Fig. 47 (Niche 9)

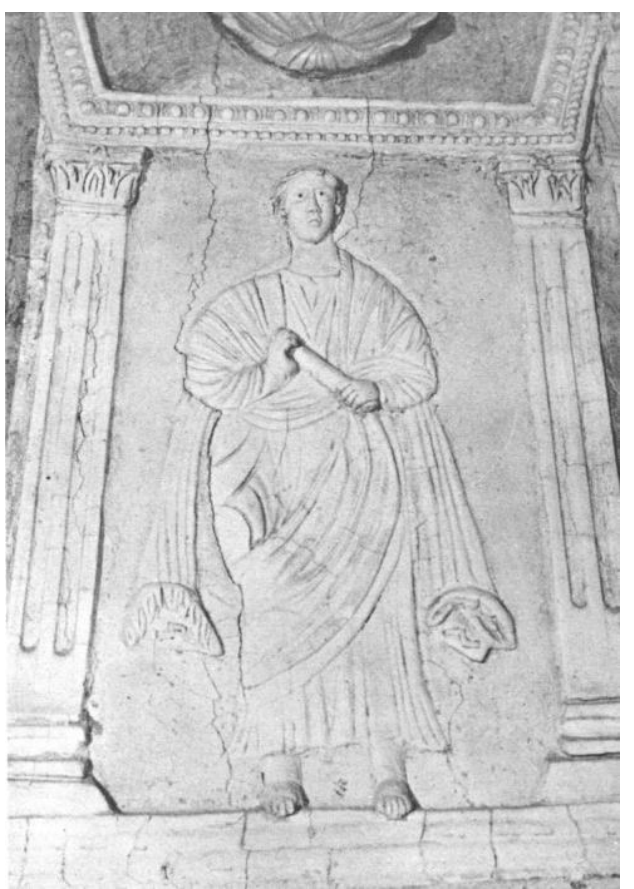

Fig. 48 (Niche 10) 


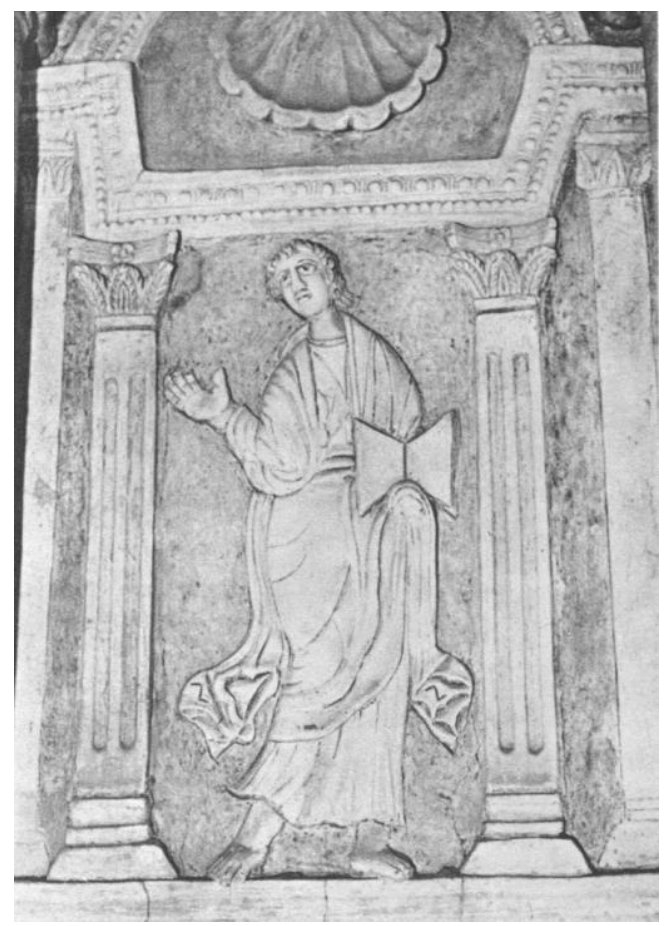

Fig. 49 (Niche 11)

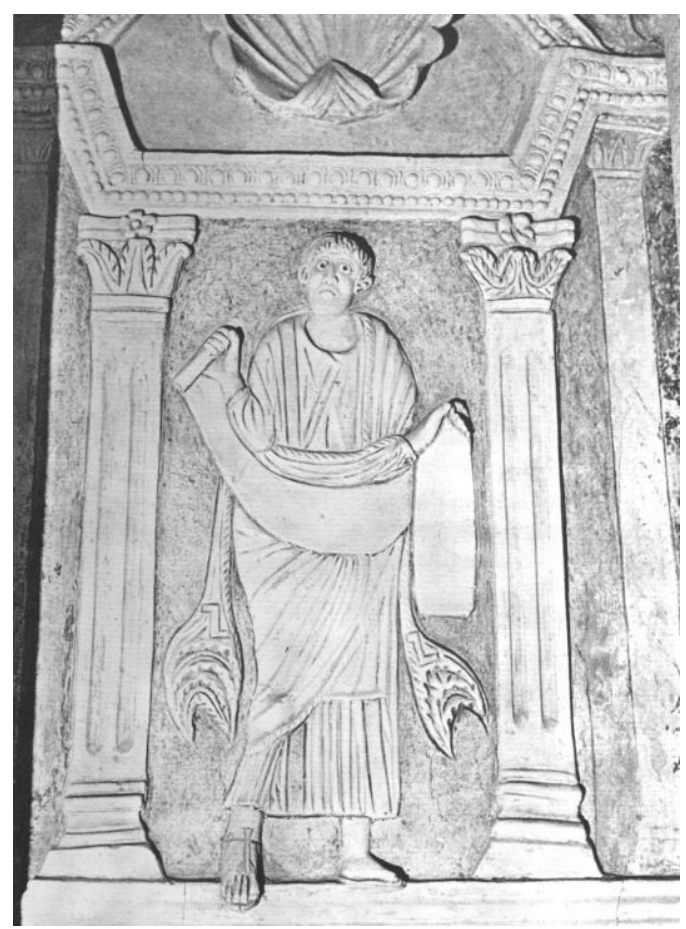

Fig. 50 (Niche 12)

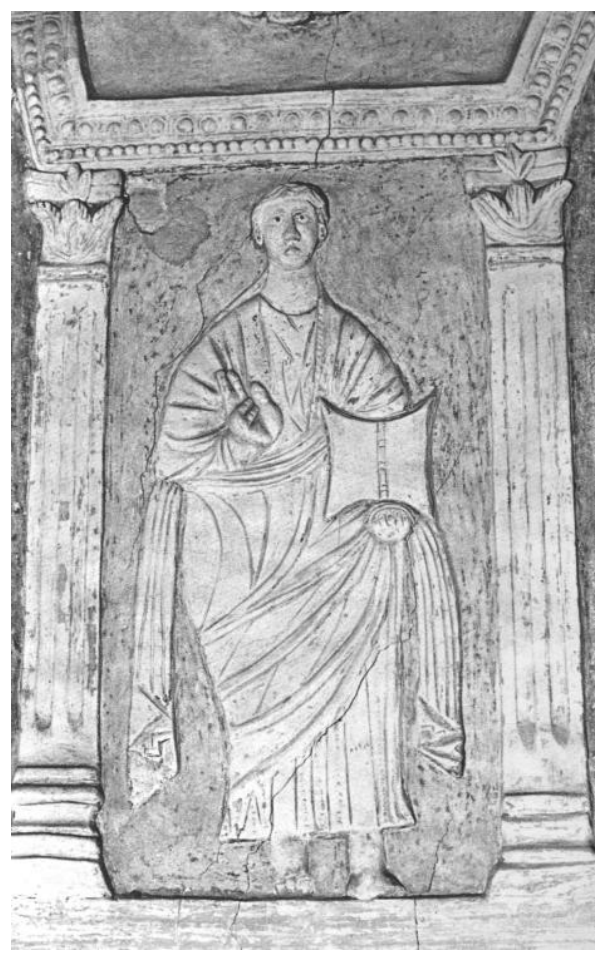

Fig. 52 (Niche 13)

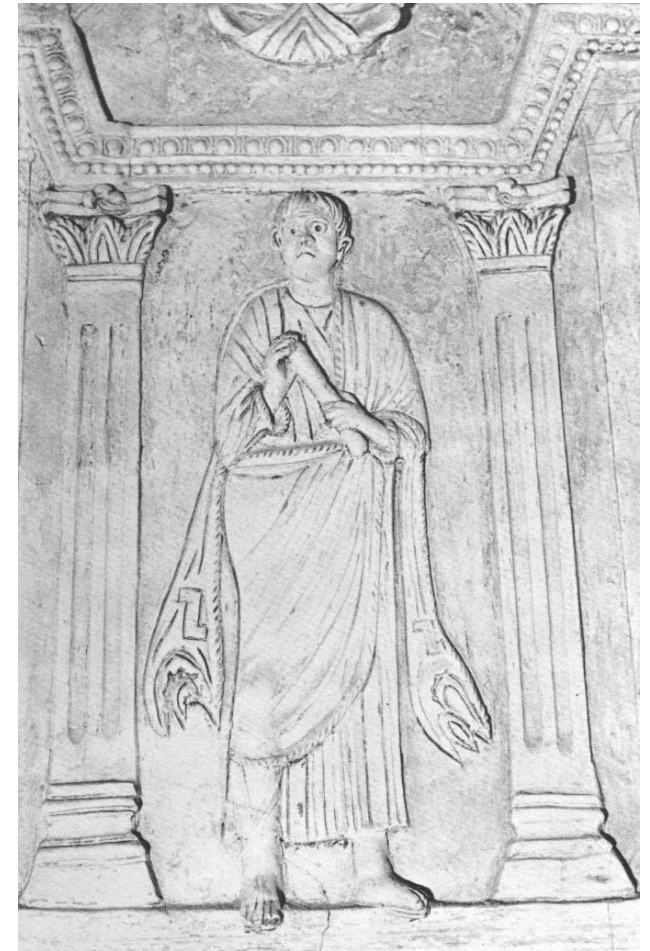

Fig. 53 (Niche 14) 


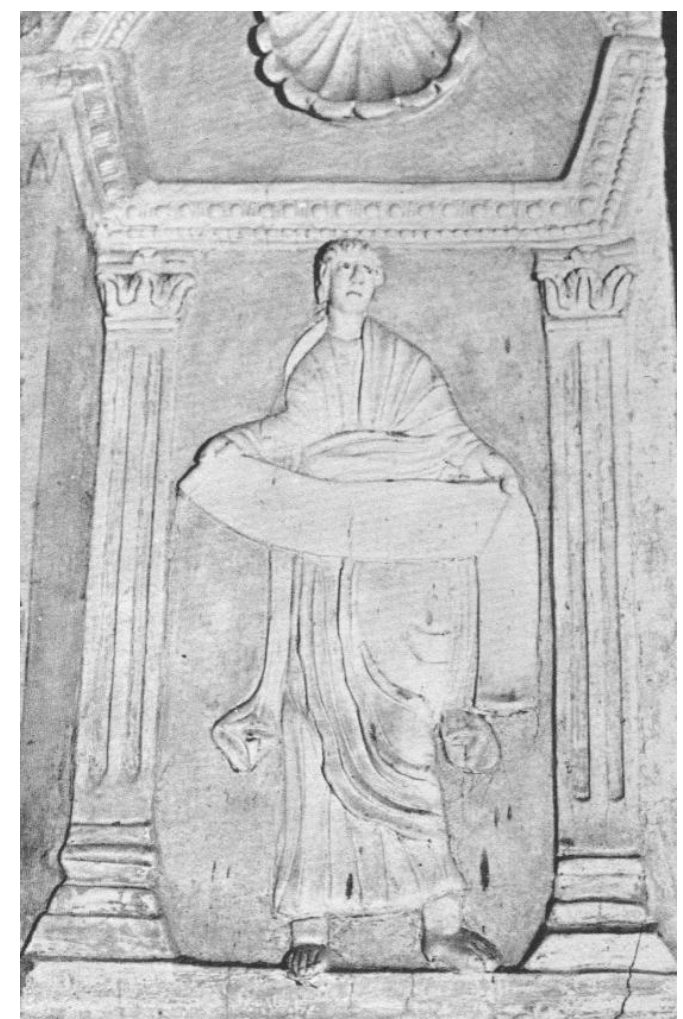

Fig. 53 (Niche 15)

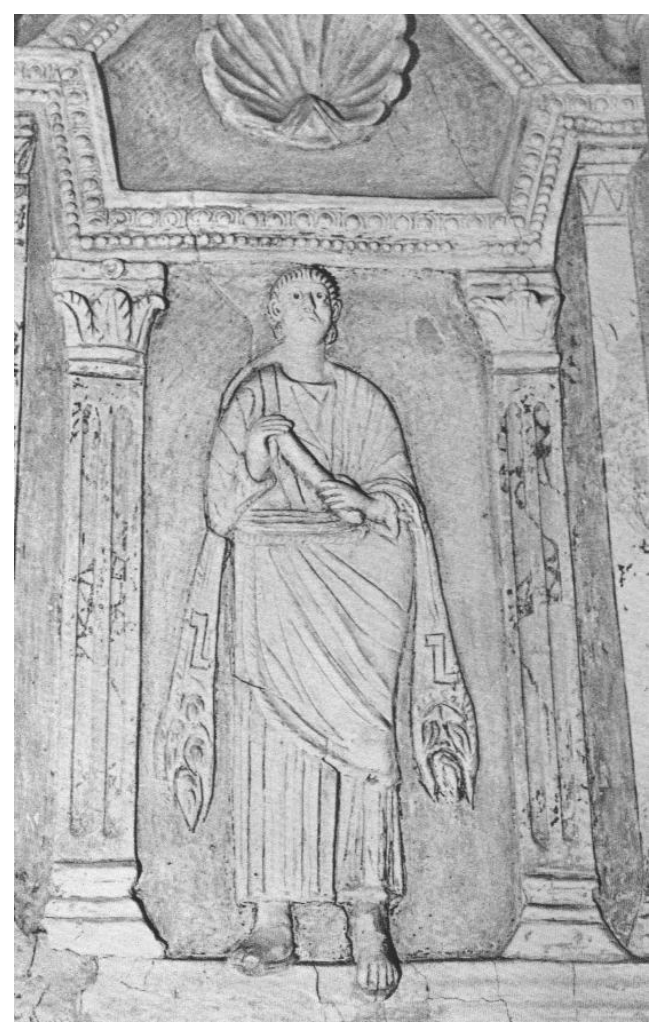

Fig. 54 (Niche 16)

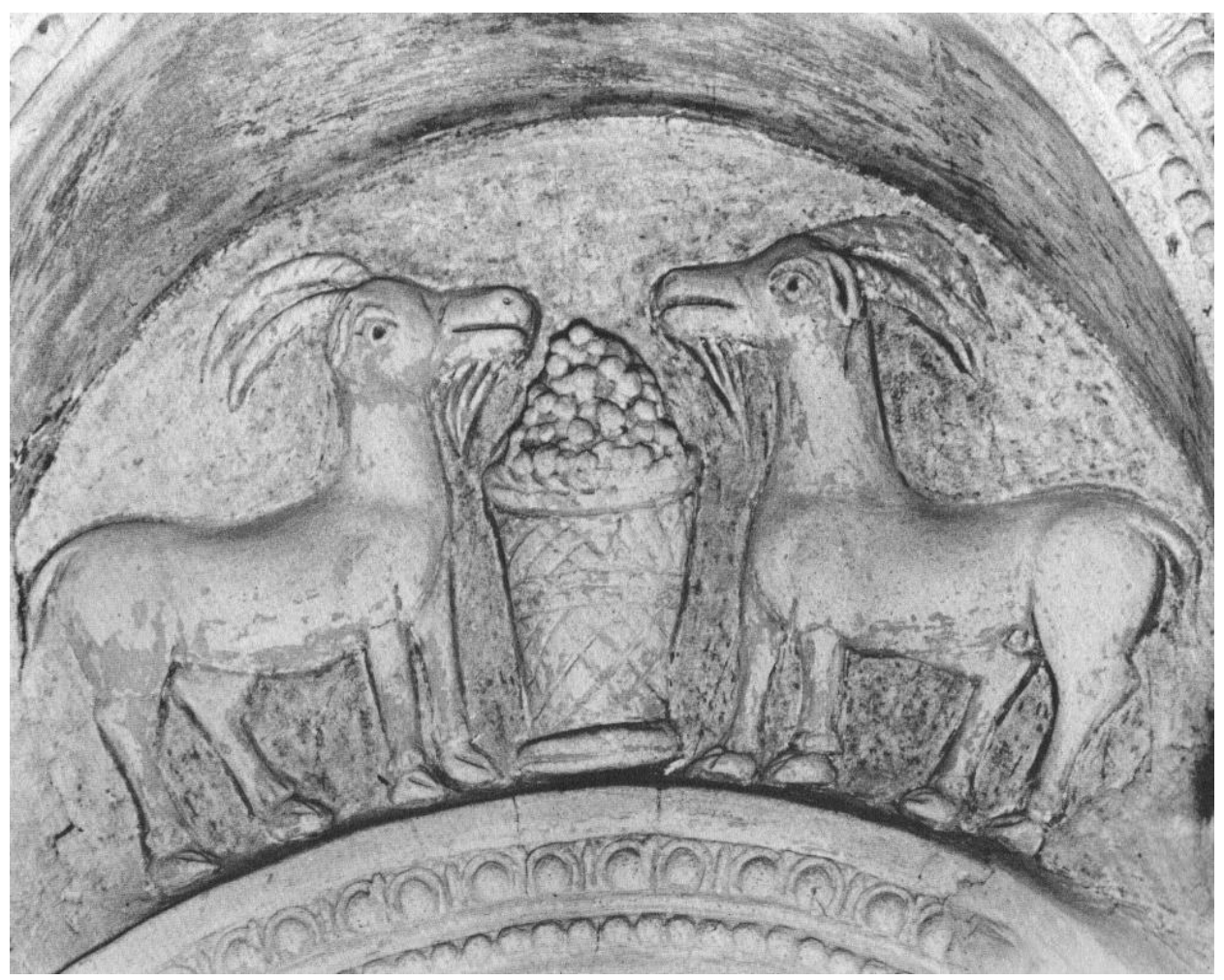

Fig. 55 (Above Niche 1) 


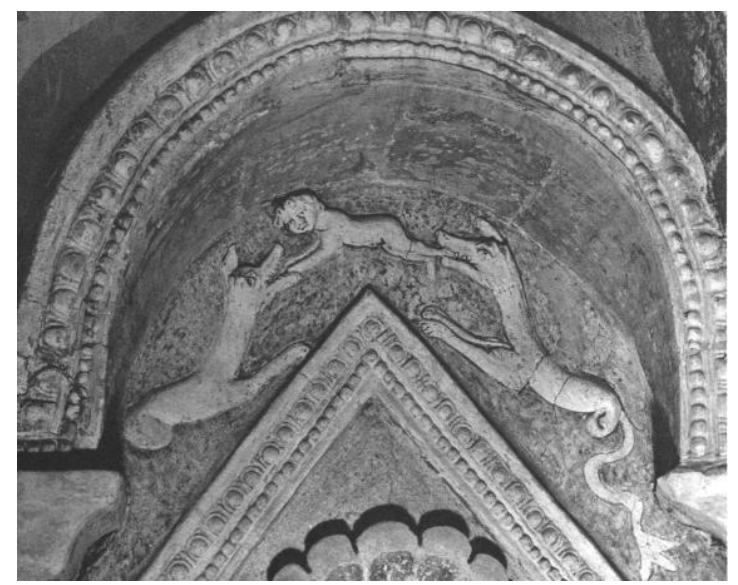

Fig. 56 (Above Niche 12)

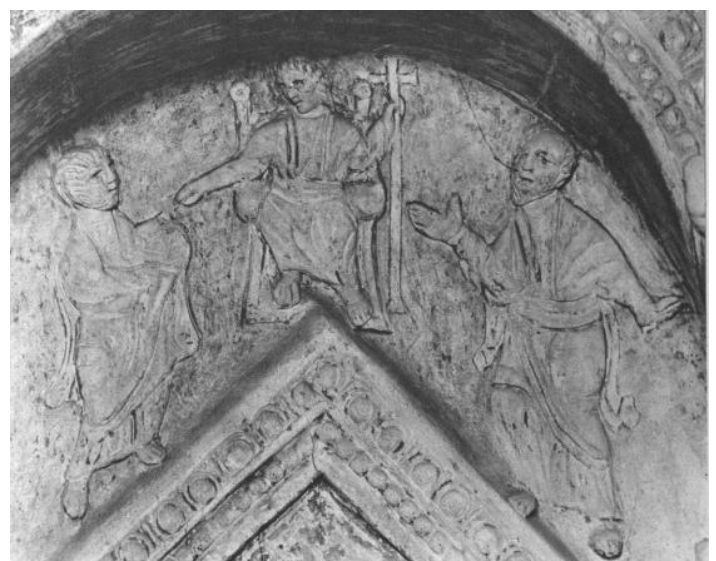

Fig. 58 (Above Niche 14)

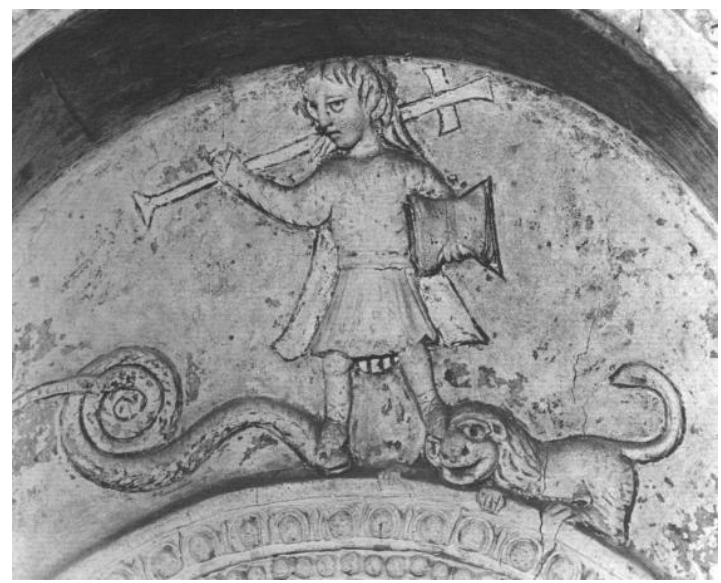

Fig. 57 (Above Niche 13)

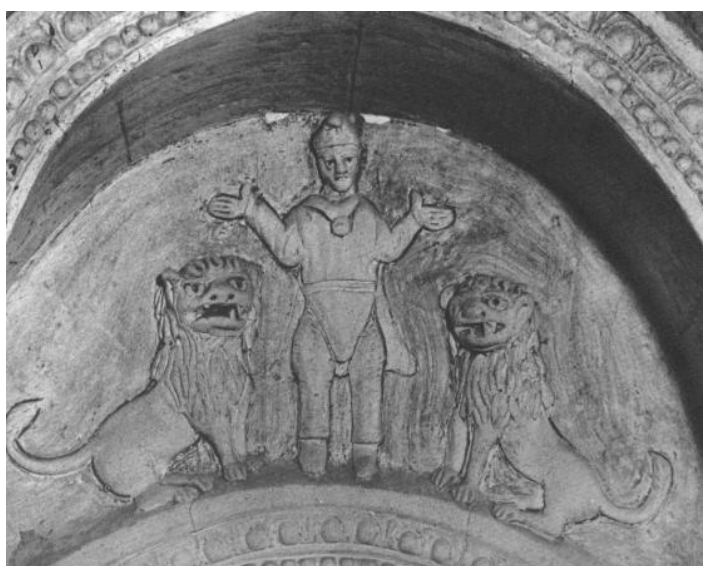

Fig. 59 (Above Niche 15)

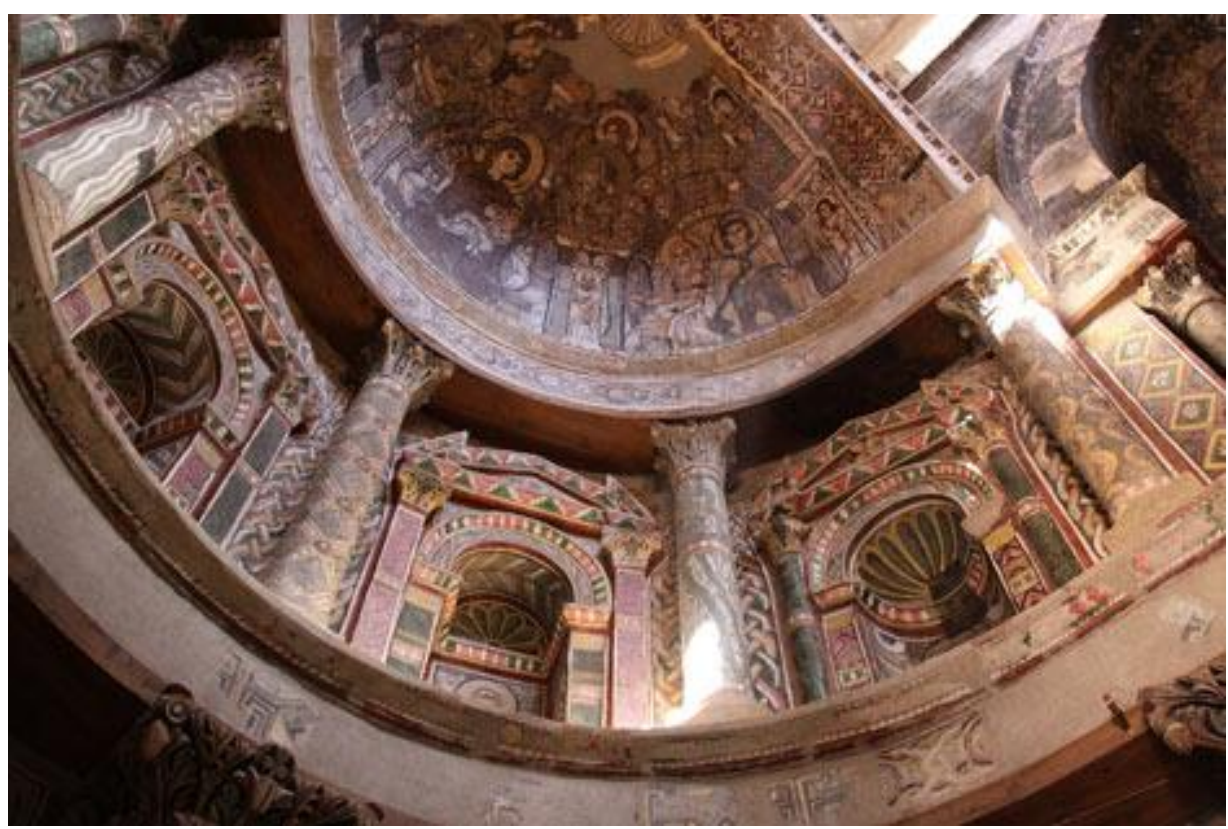

Fig. 60 


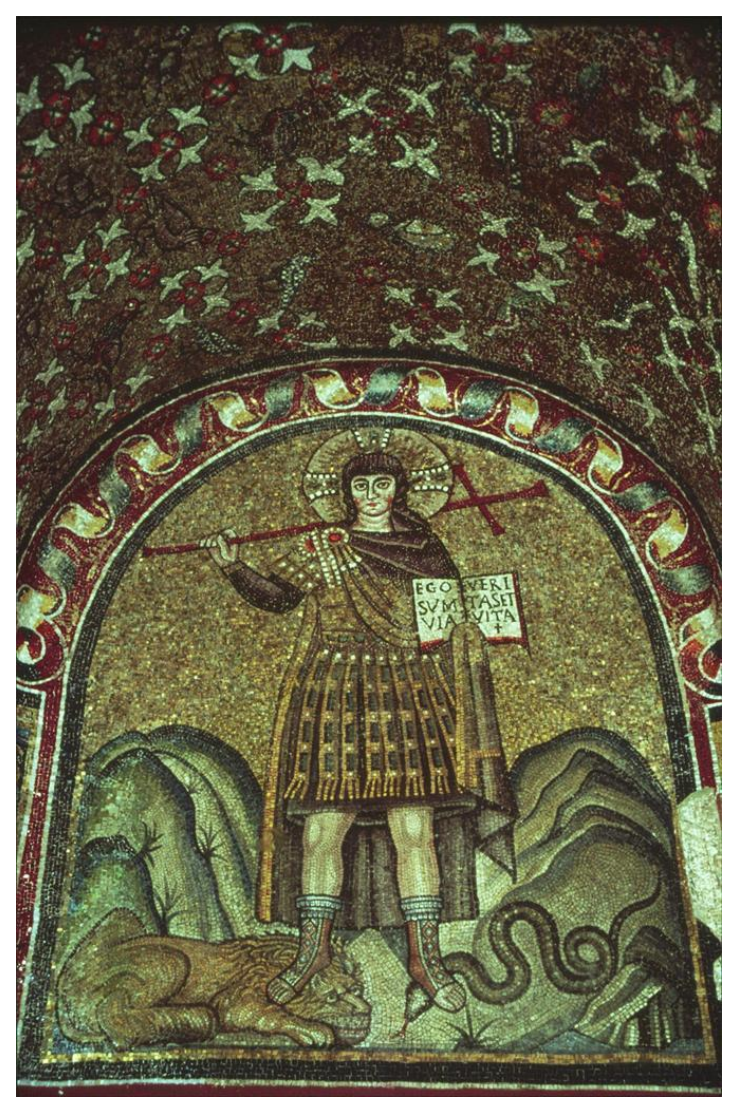

Fig. 61

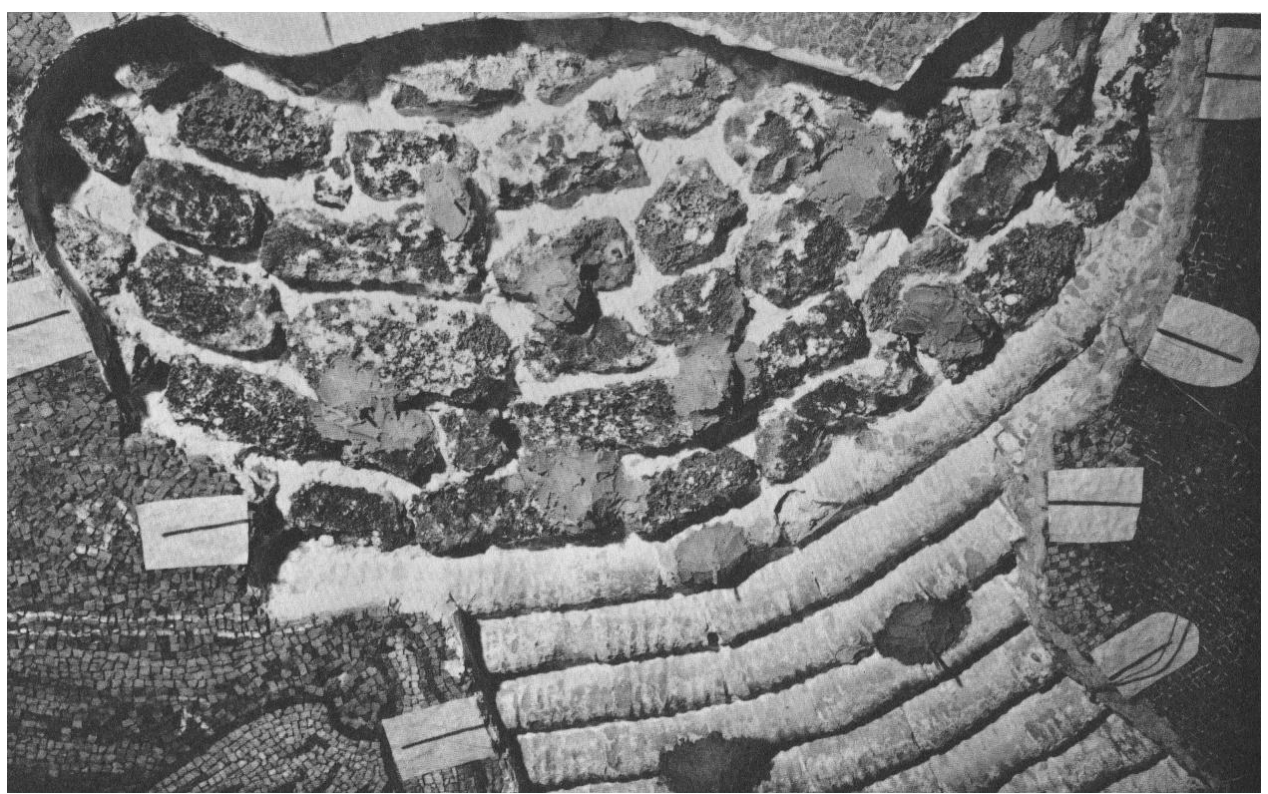

Fig. 62 


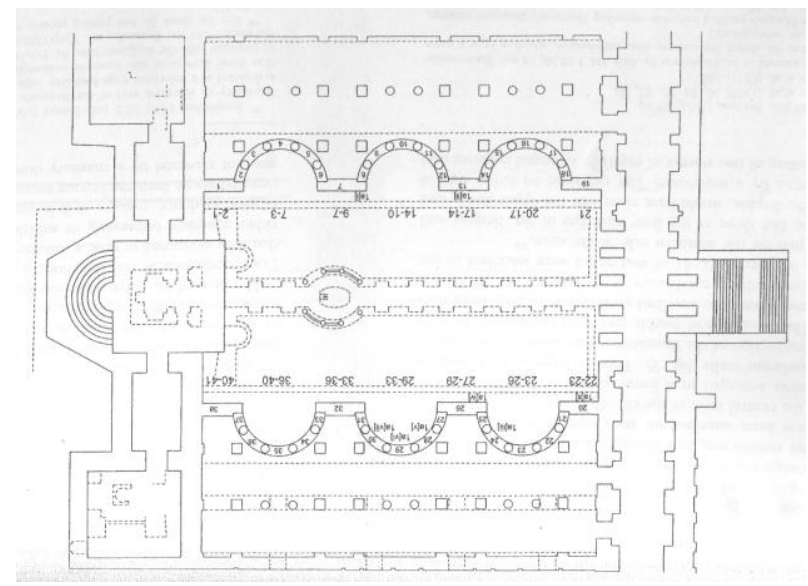

Fig. 63

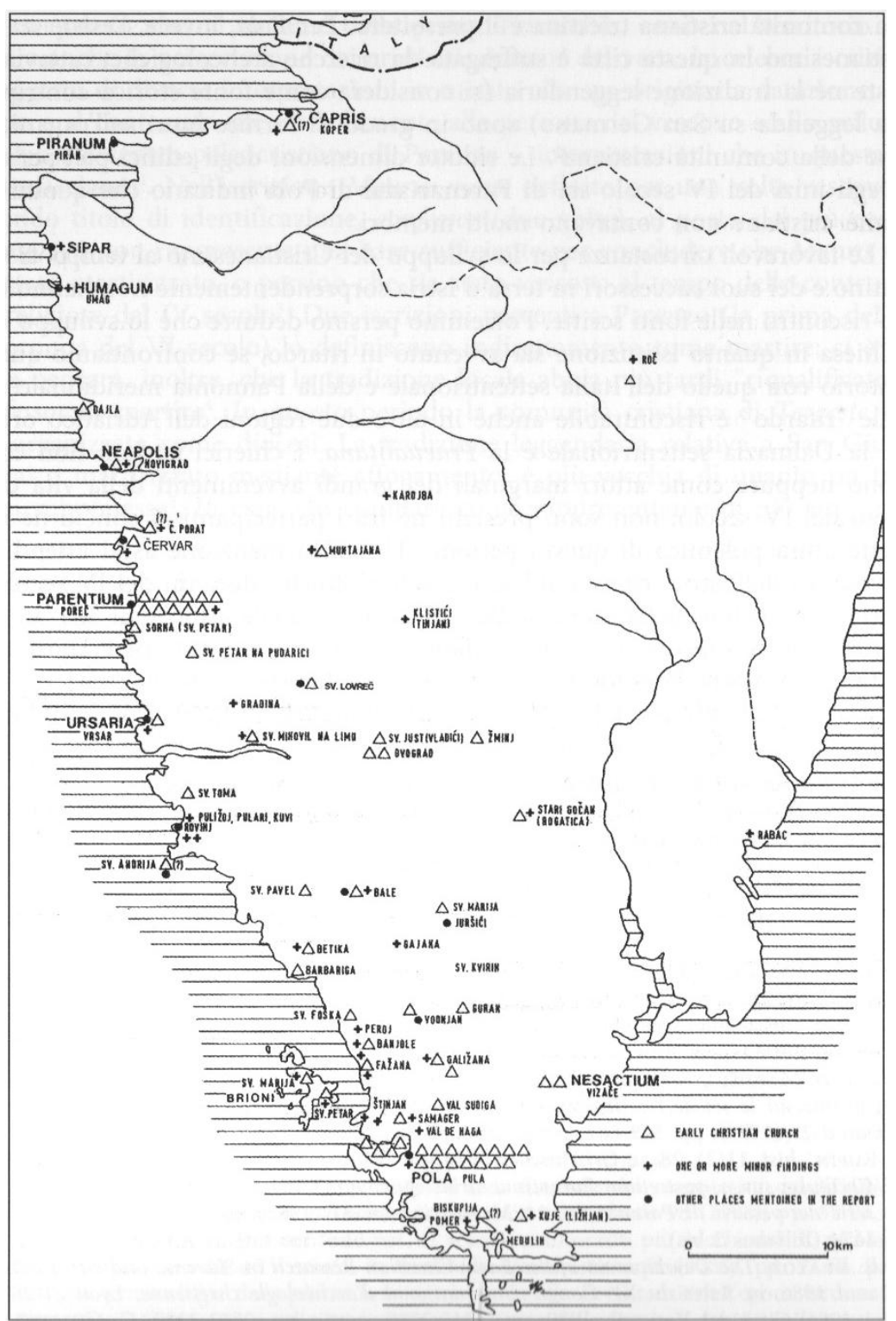

Fig. 64 


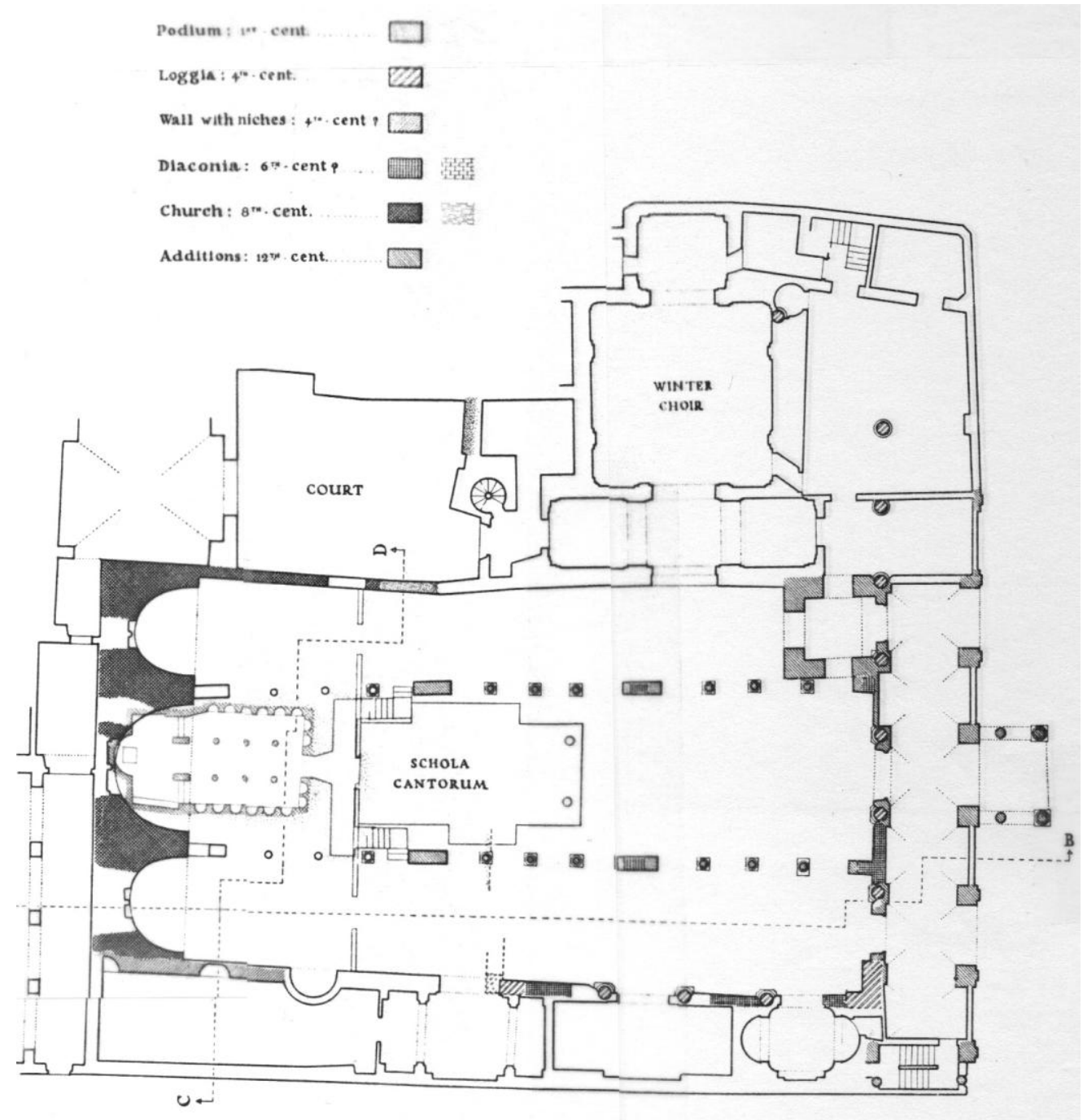

Fig. 65

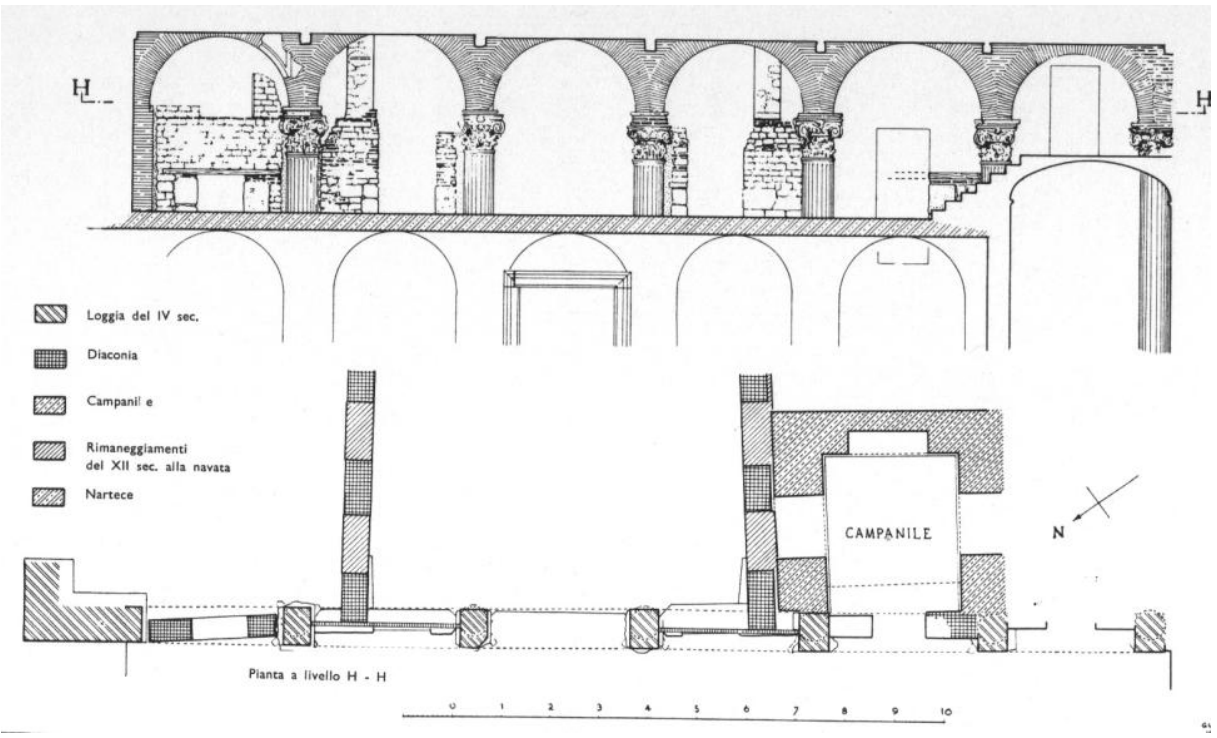

Fig. 66 


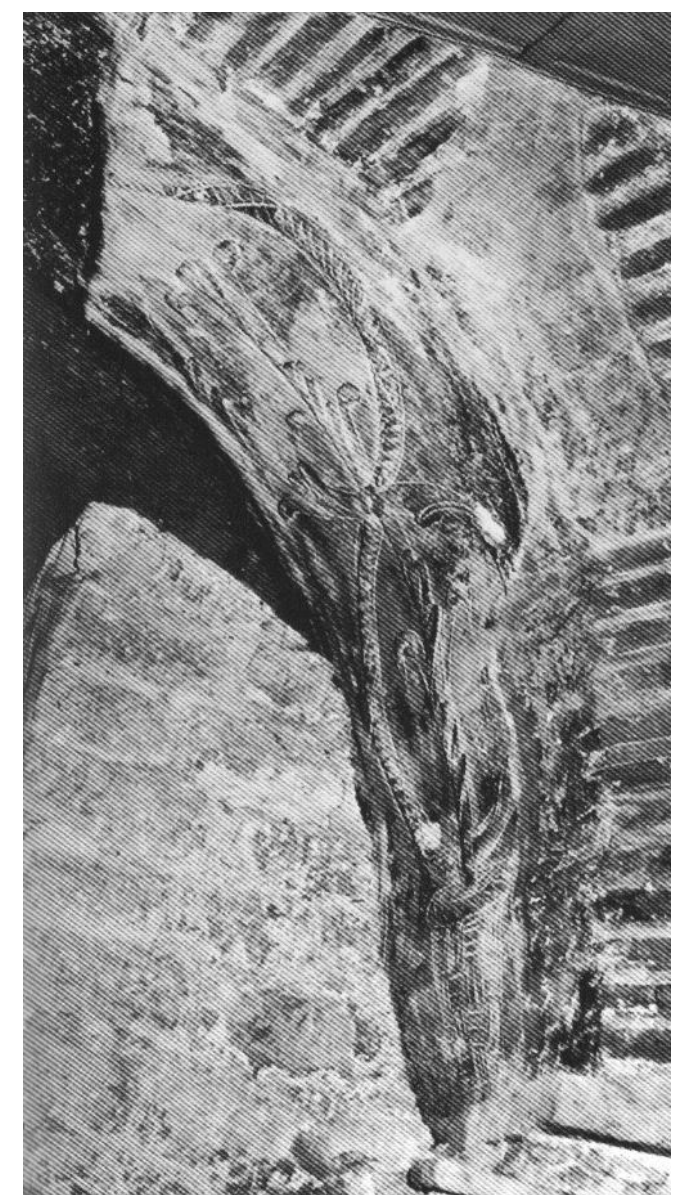

Fig. 67

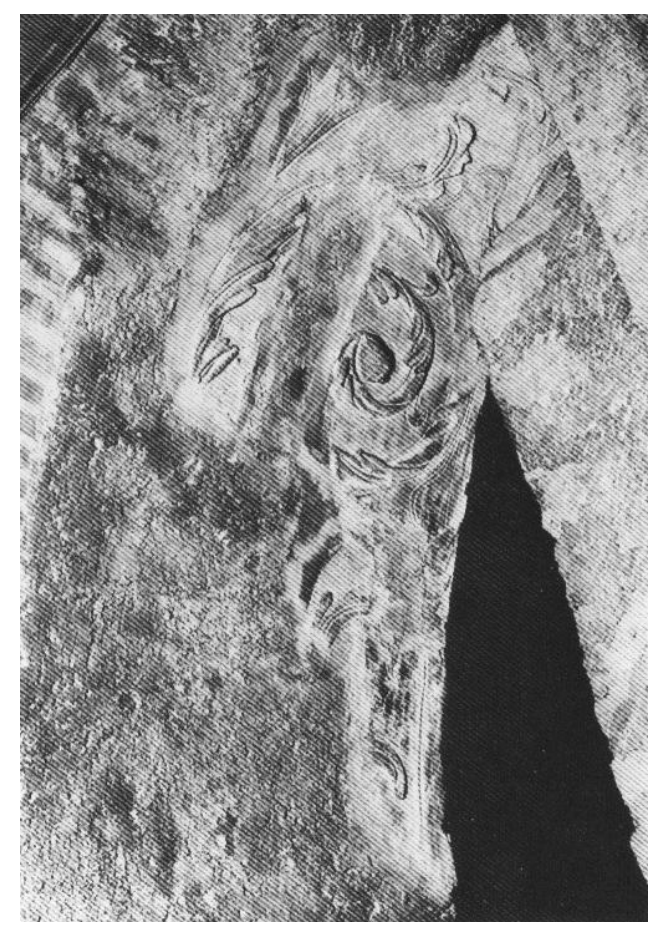

Fig. 68

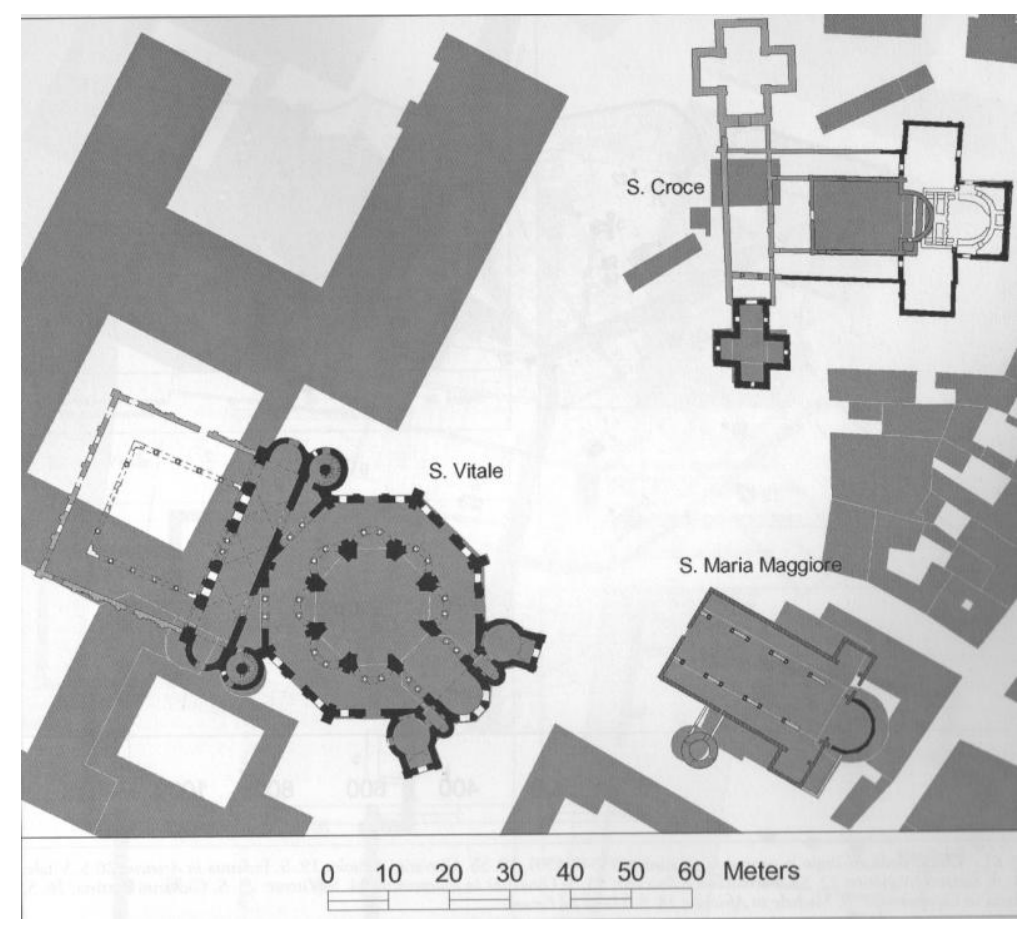

Fig. 69 


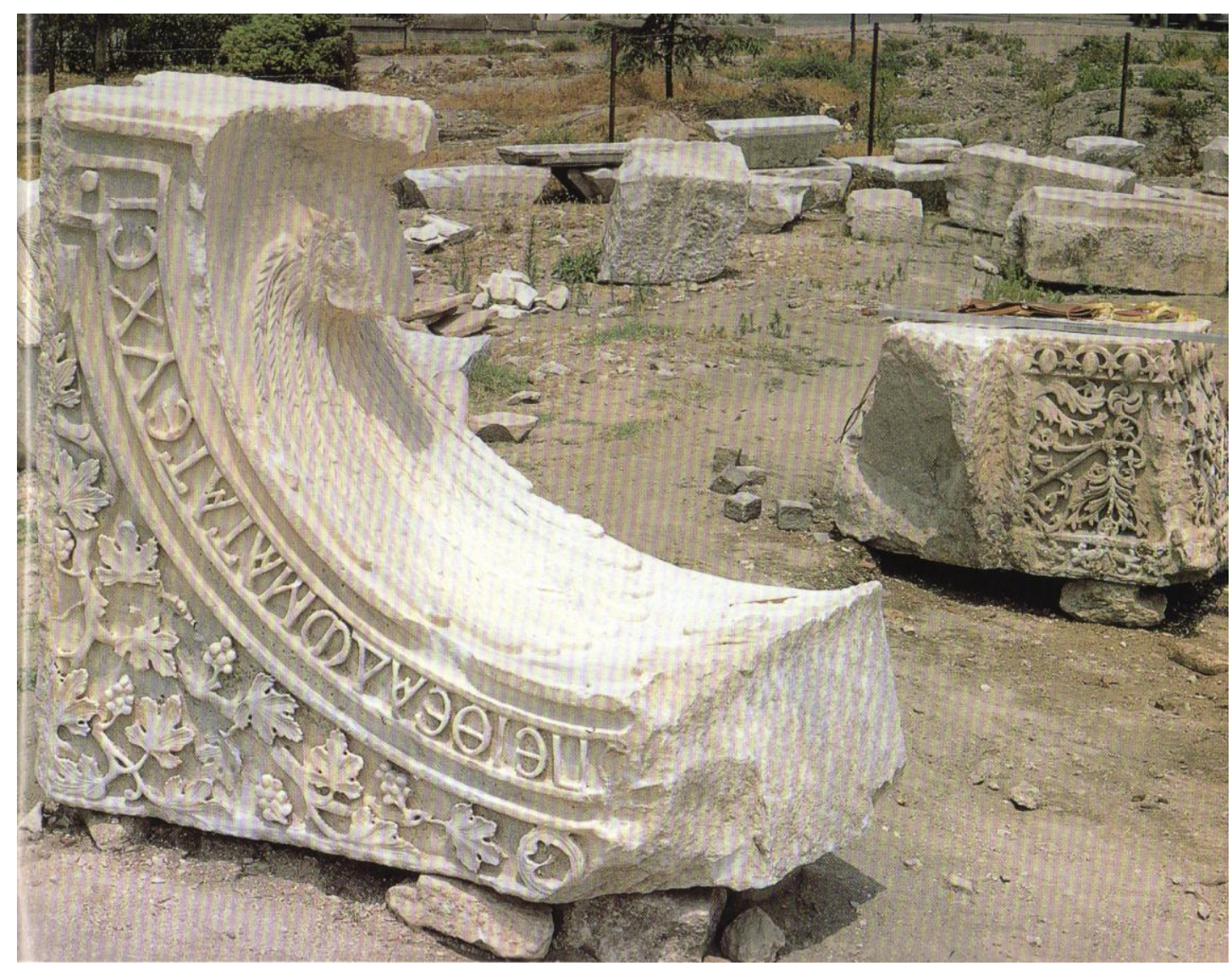

Fig. 70

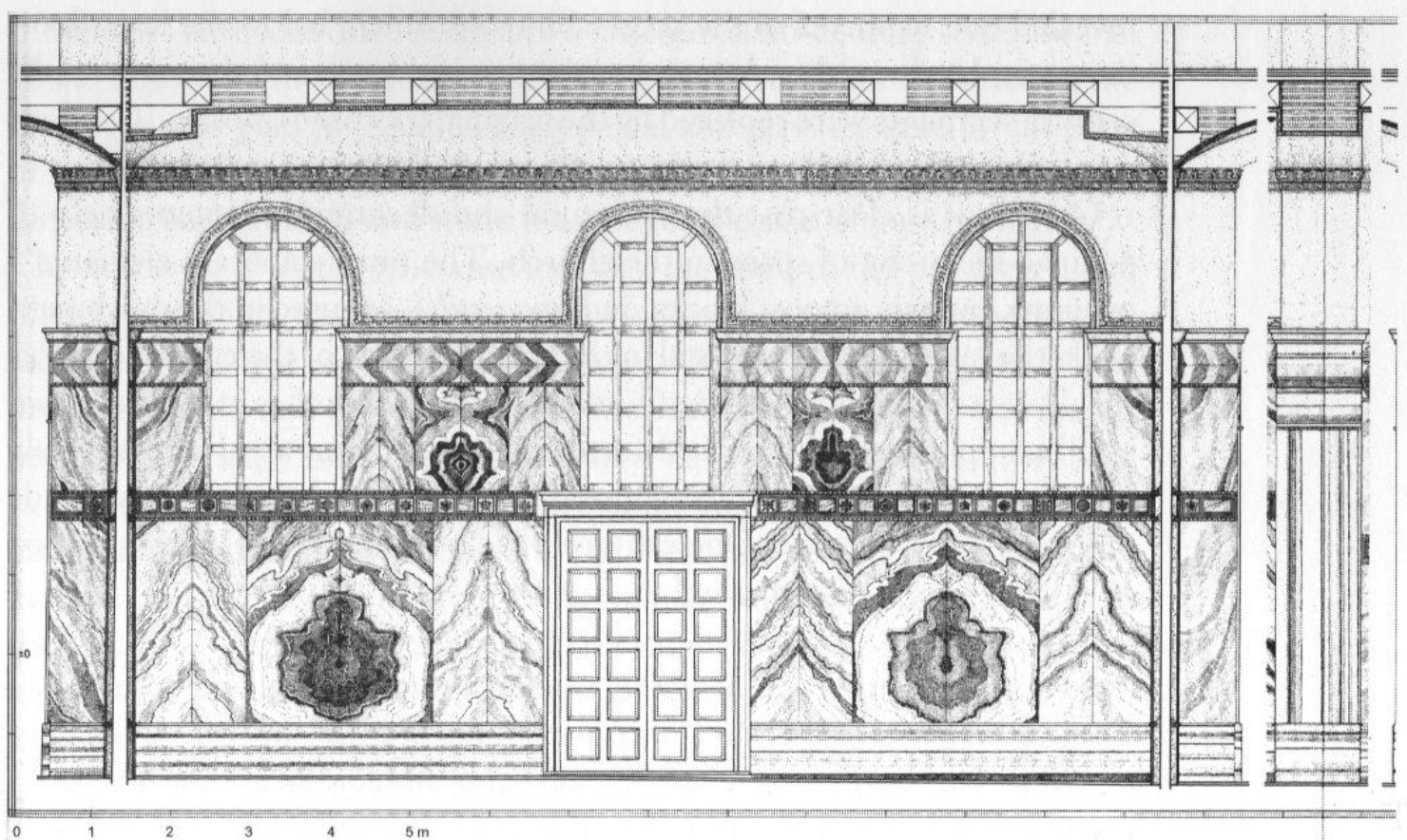

Fig. 71 


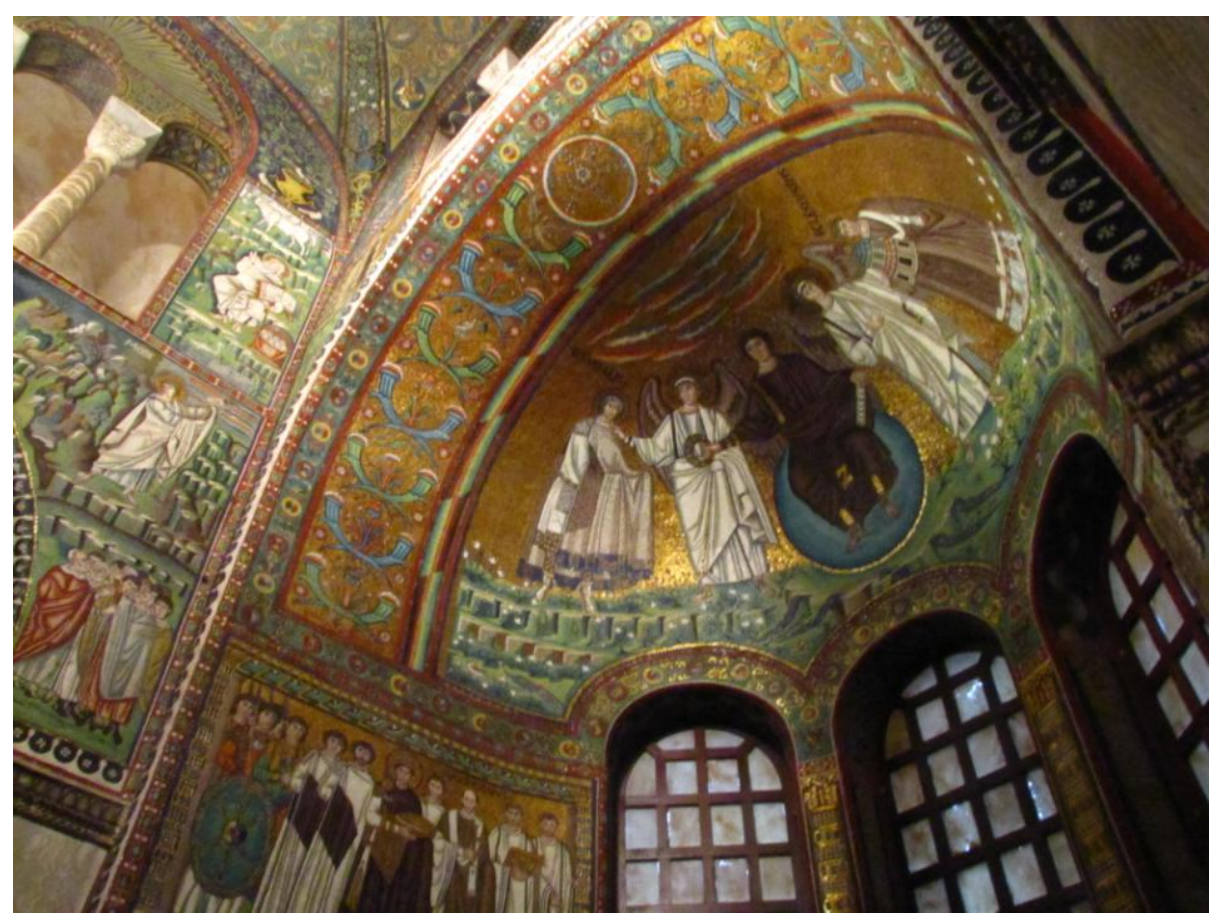

Fig. 72

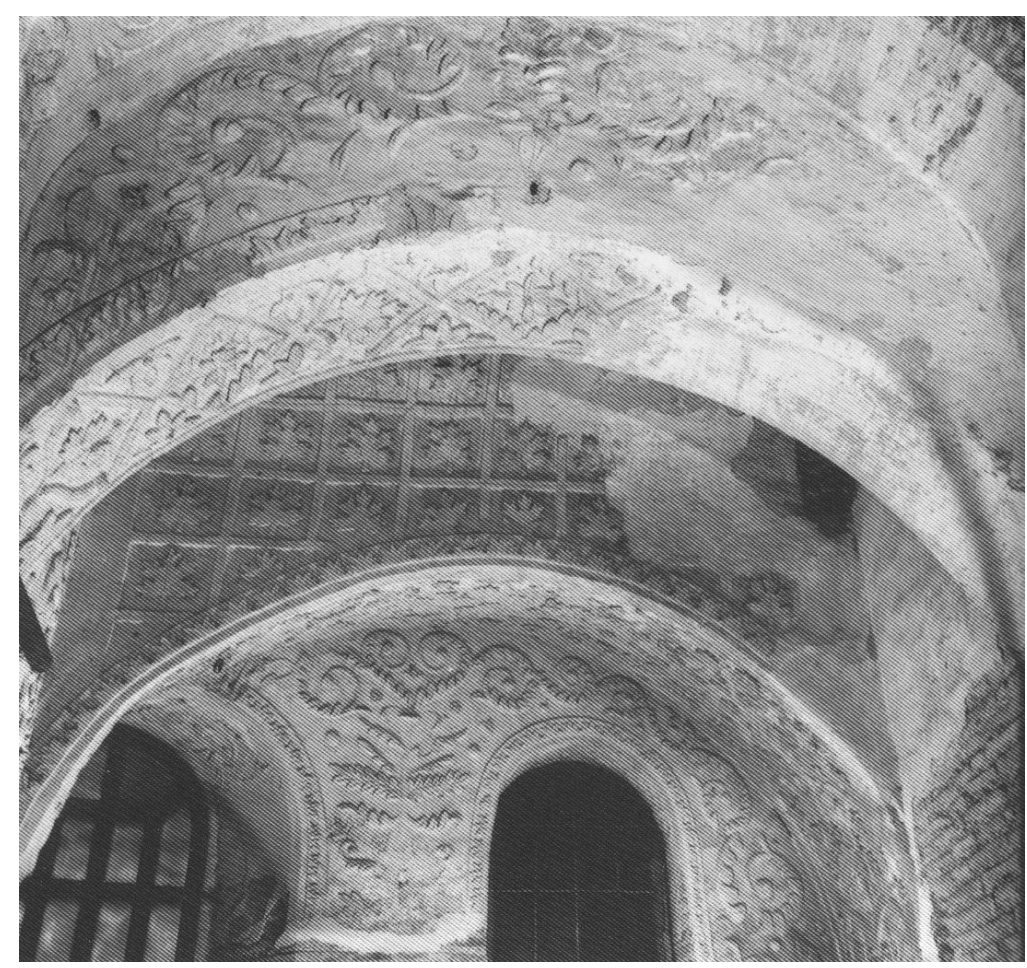

Fig. 73 


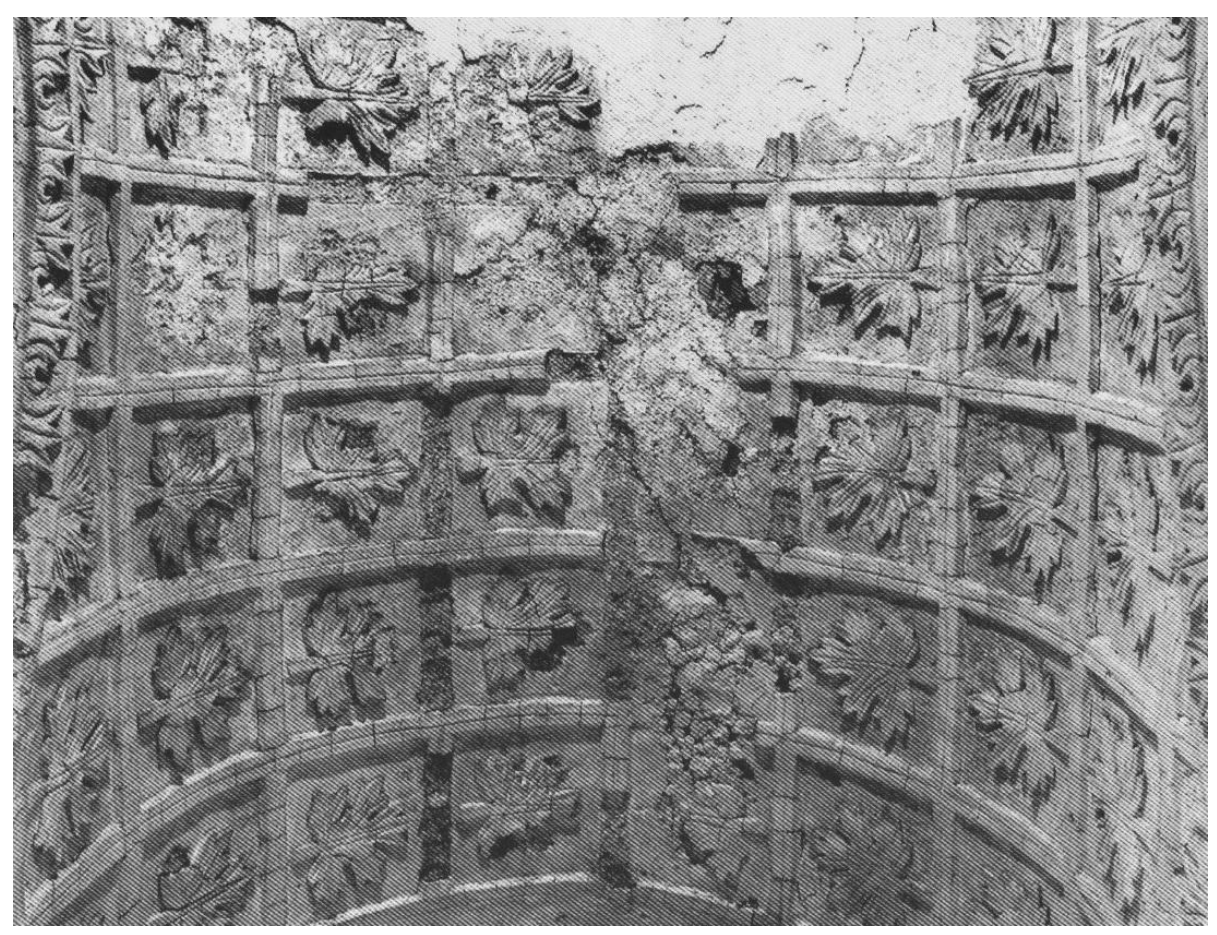

Fig. 74

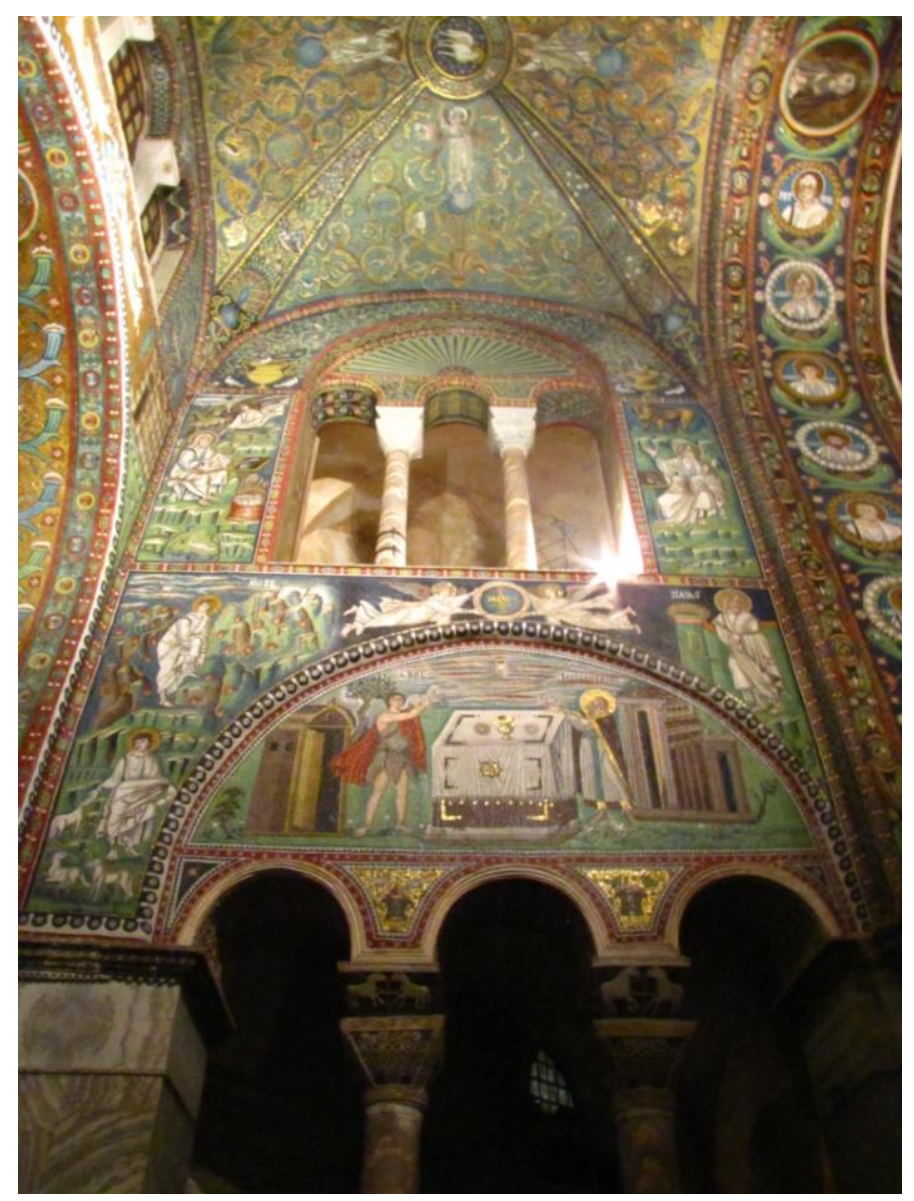

Fig. 75 


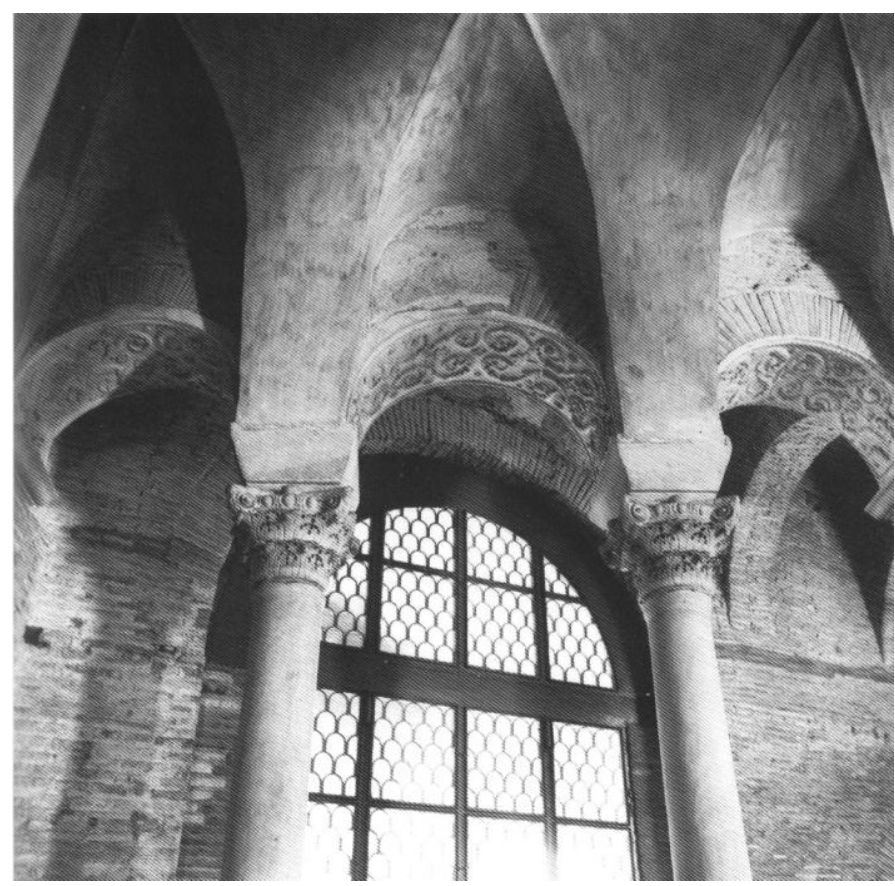

Fig. 76

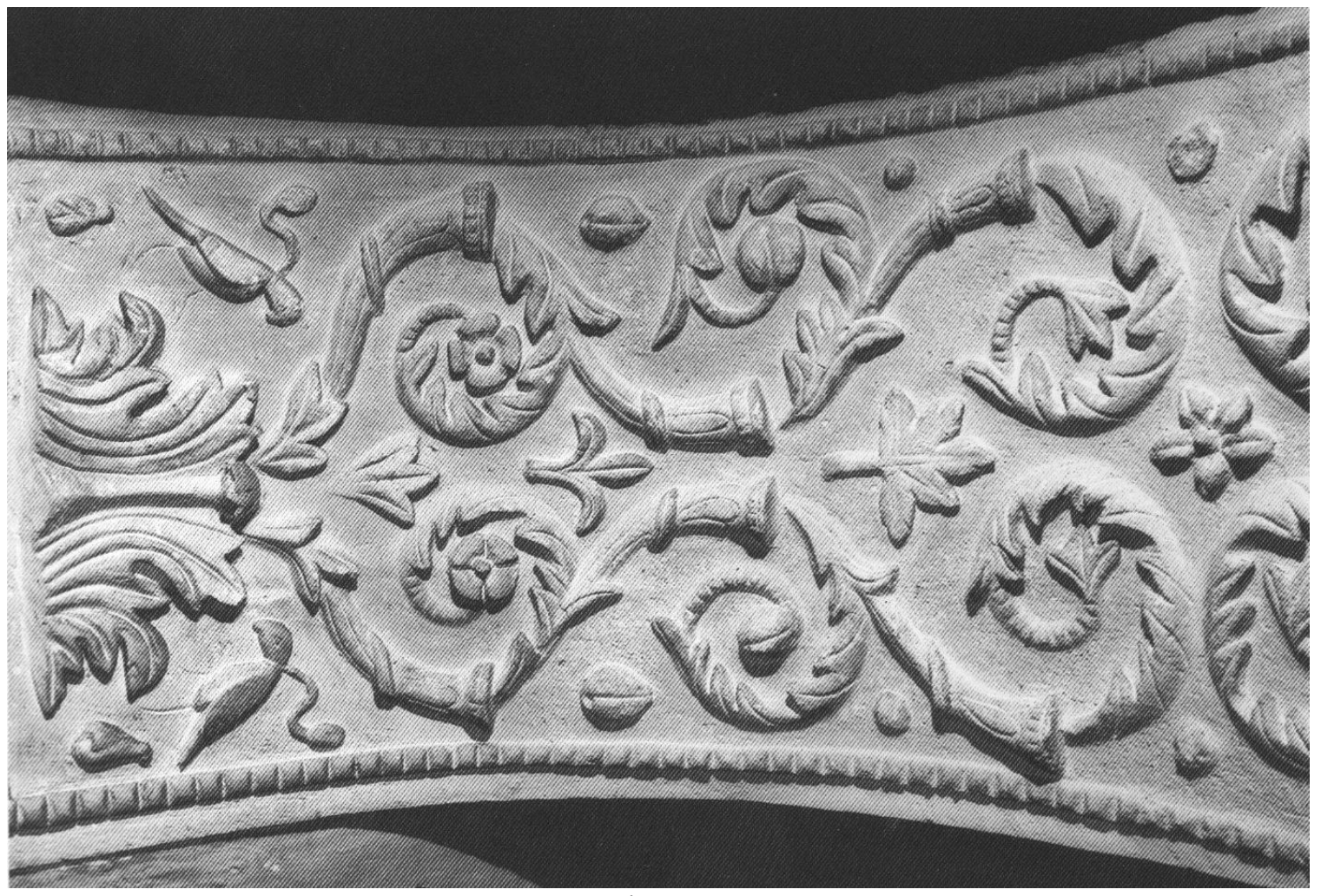

Fig. 77 


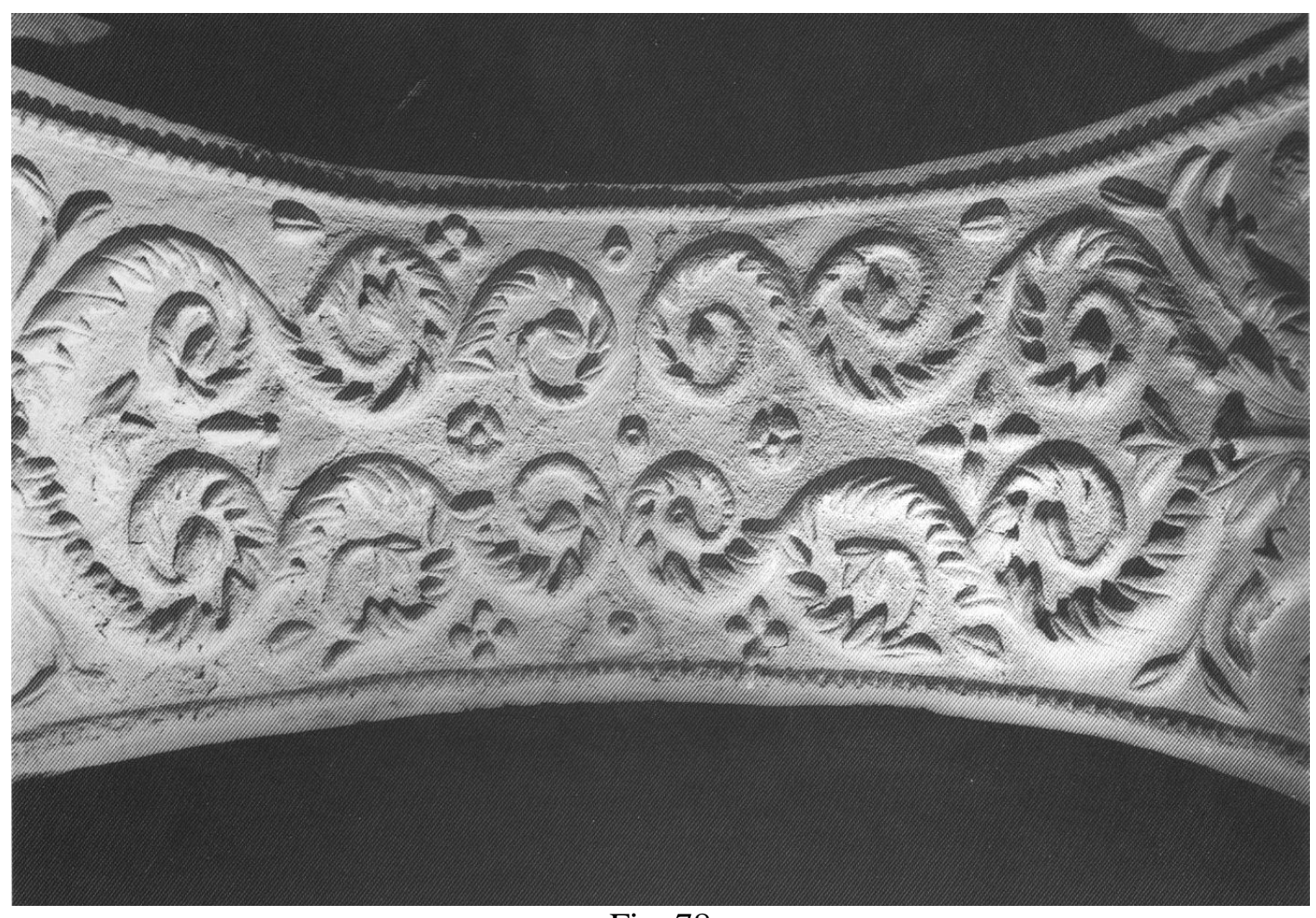

Fig. 78

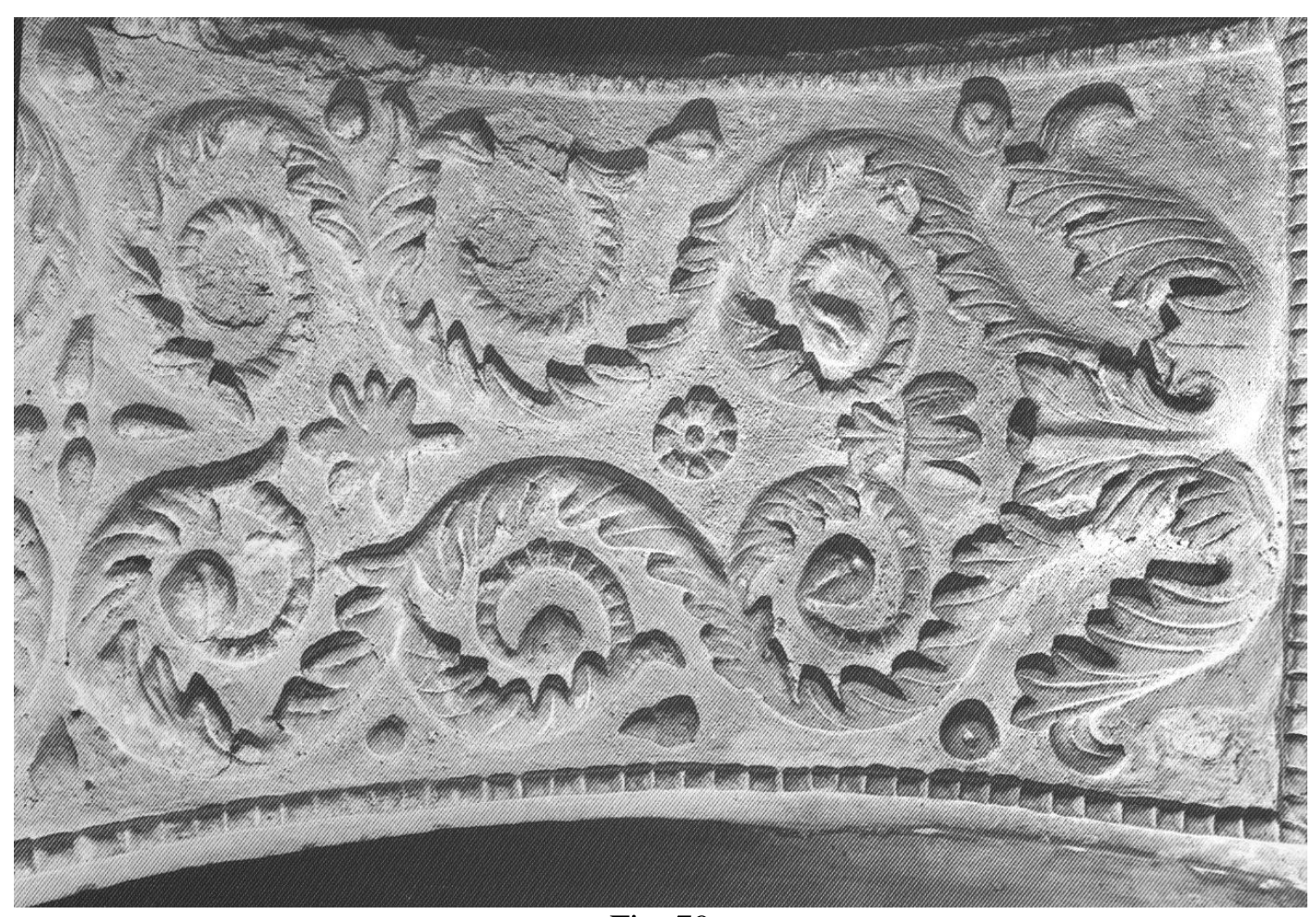

Fig. 79 


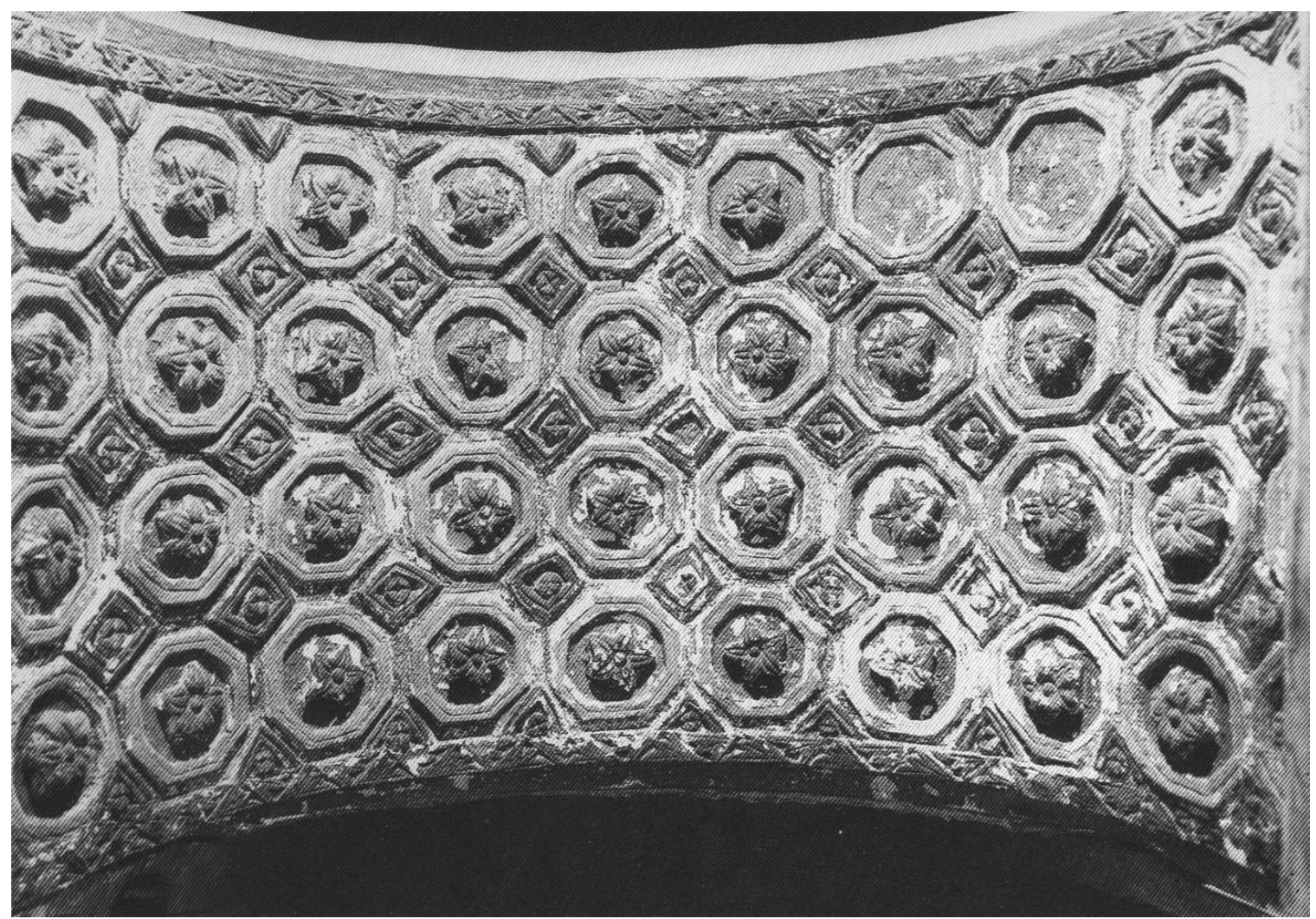

Fig. 80

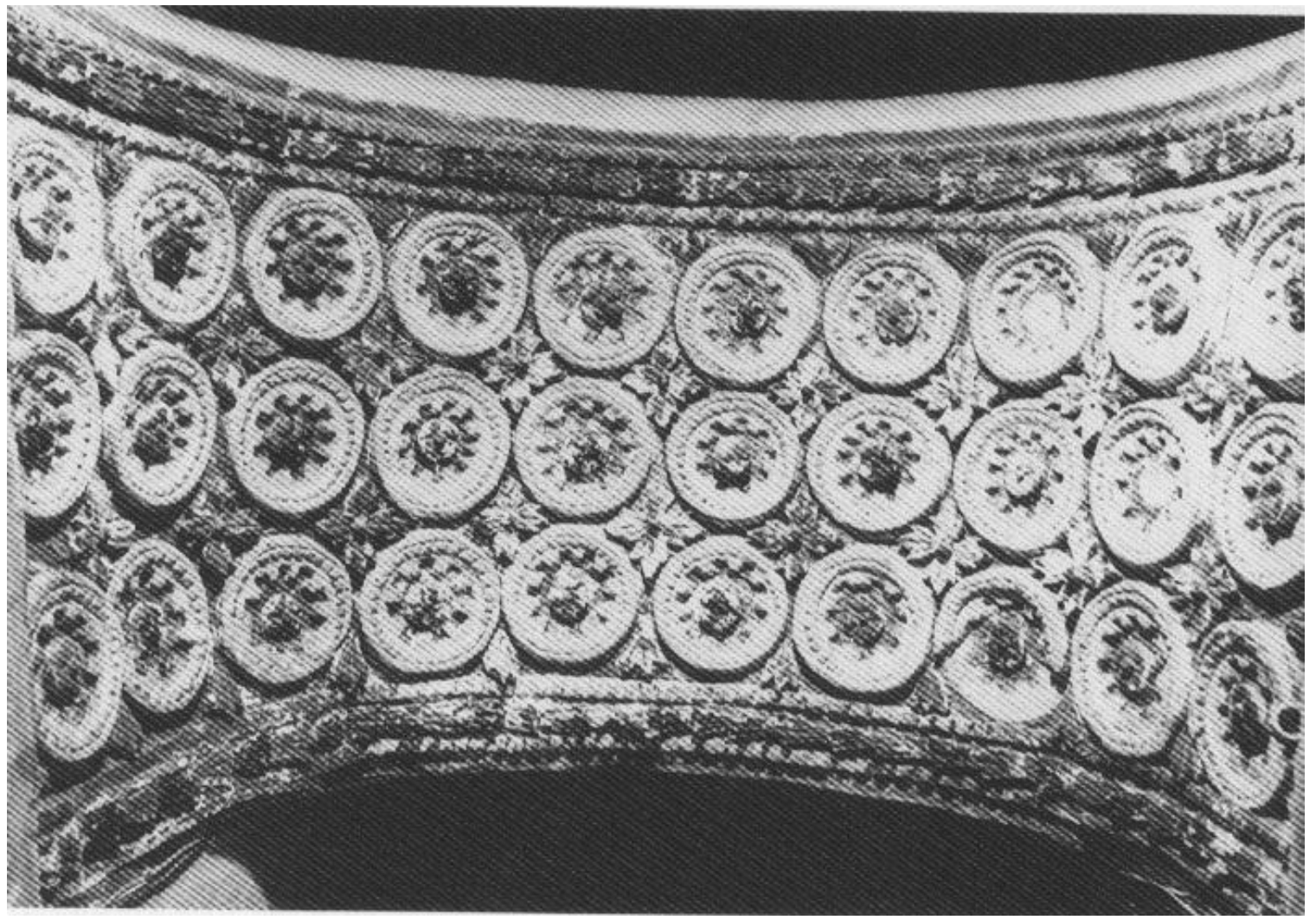

Fig. 81 


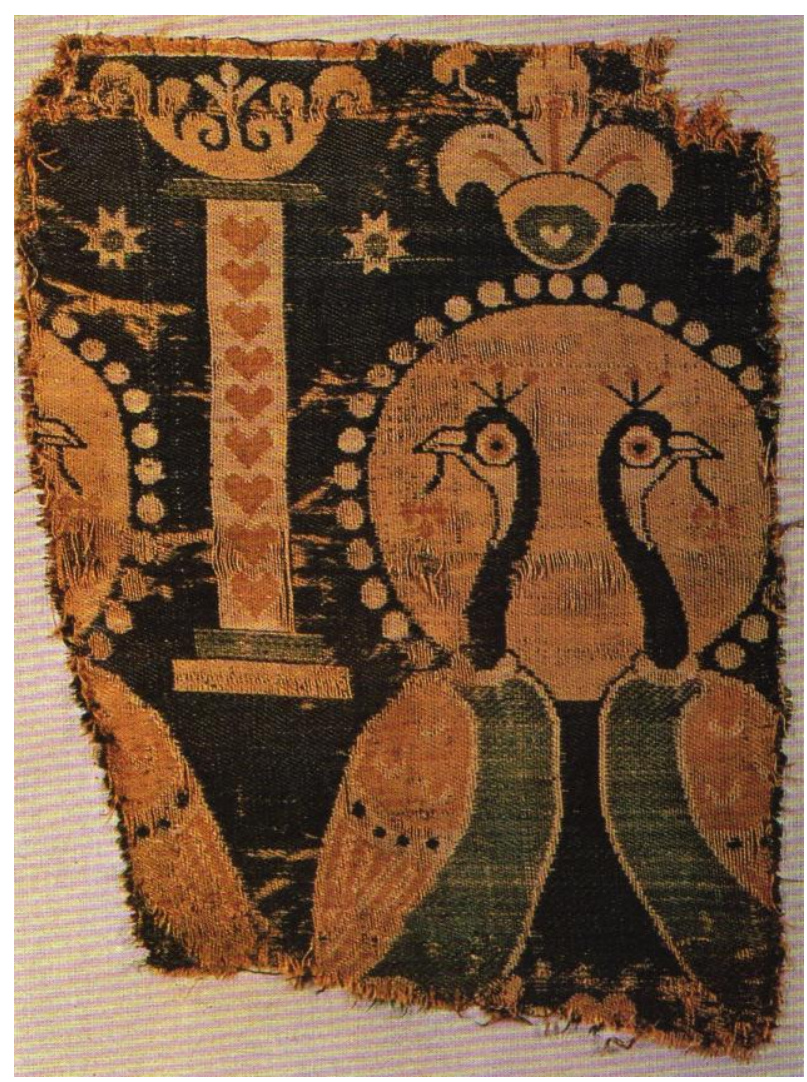

Fig. 82

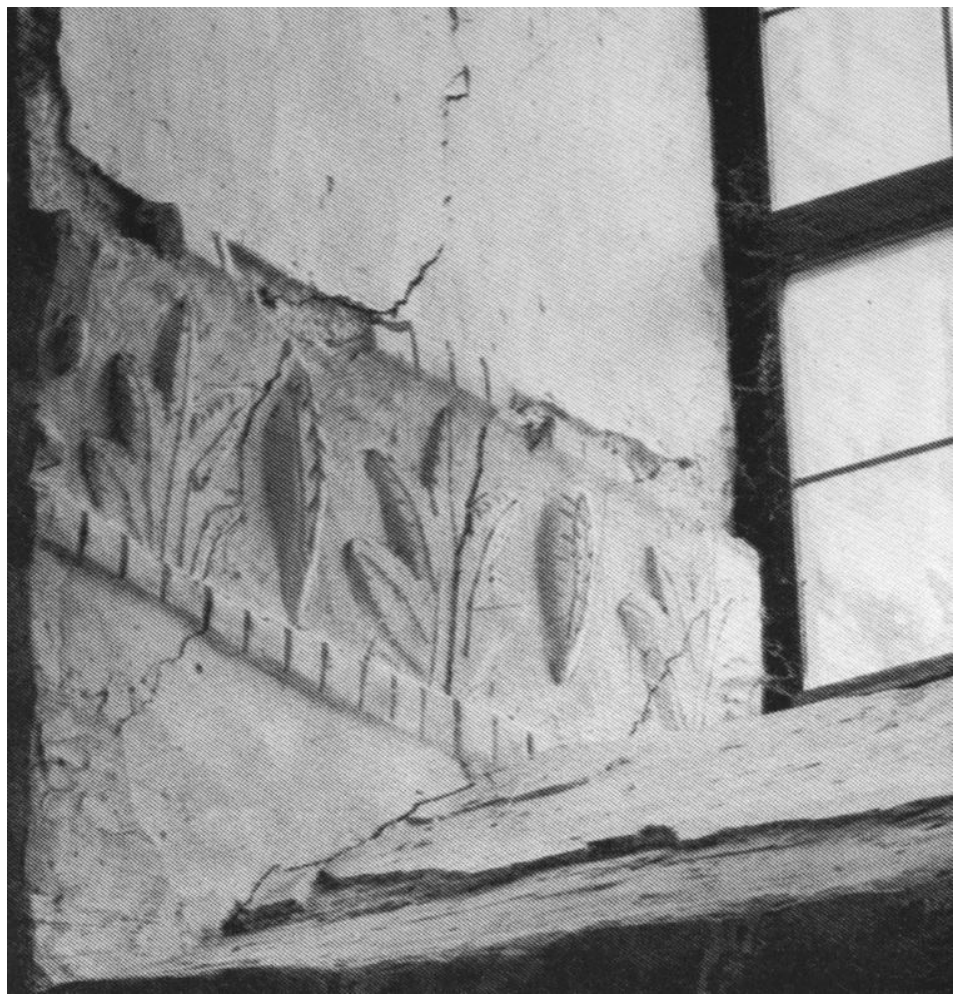

Fig. 83 


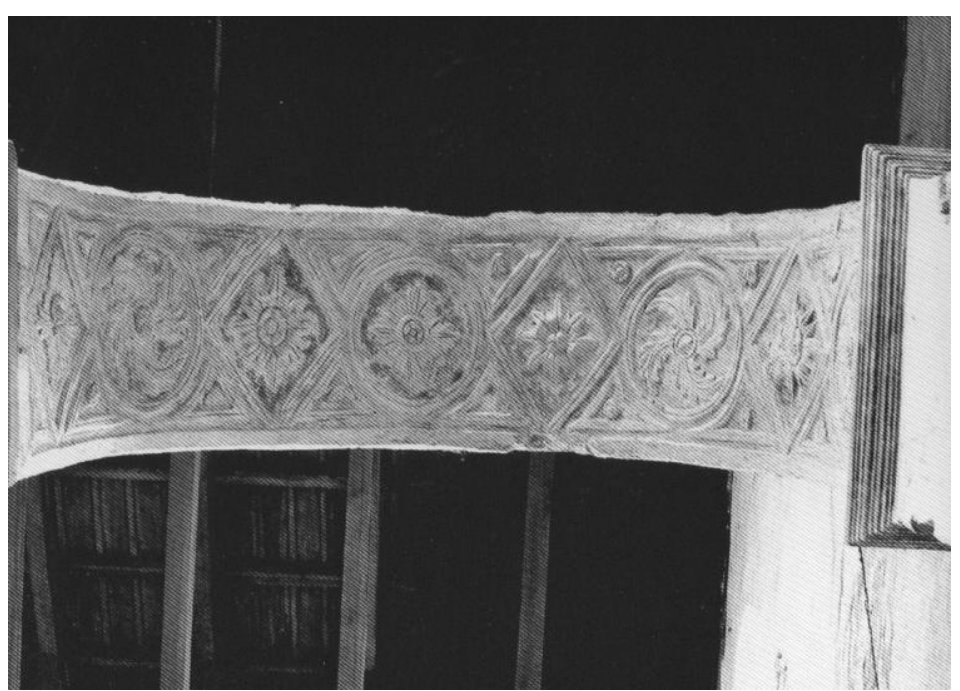

Fig. 84

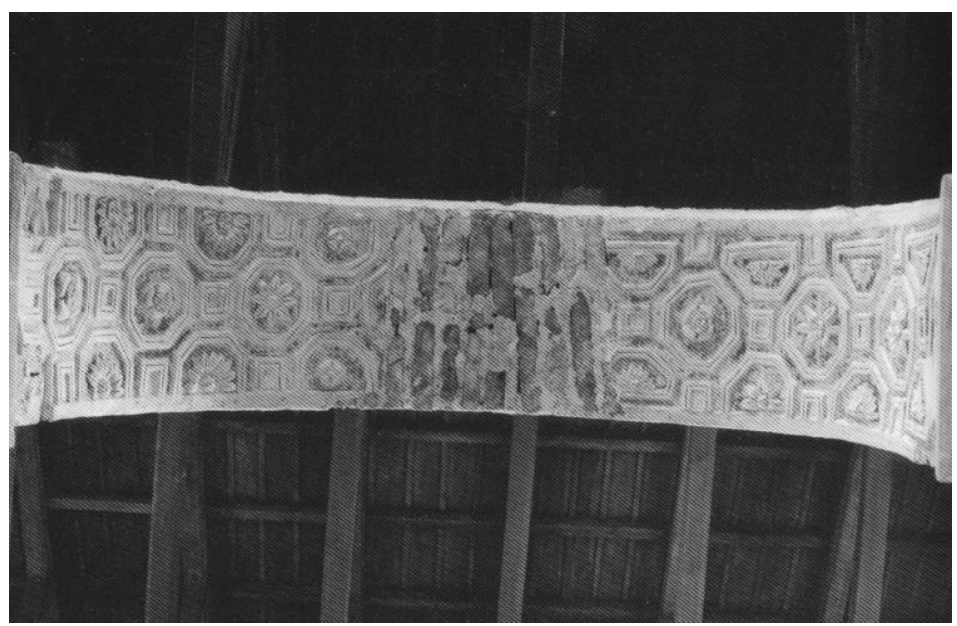

Fig. 85

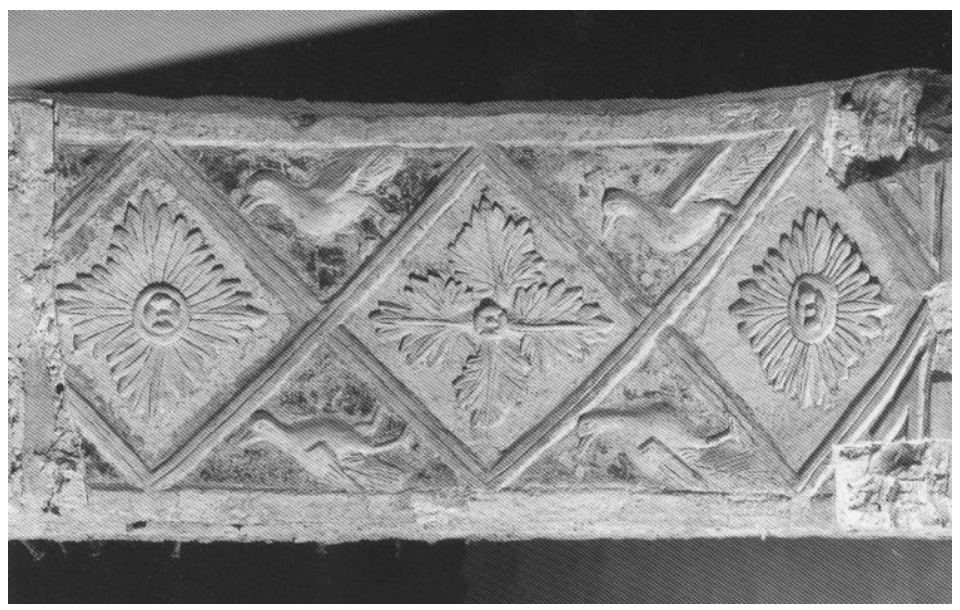

Fig. 86 

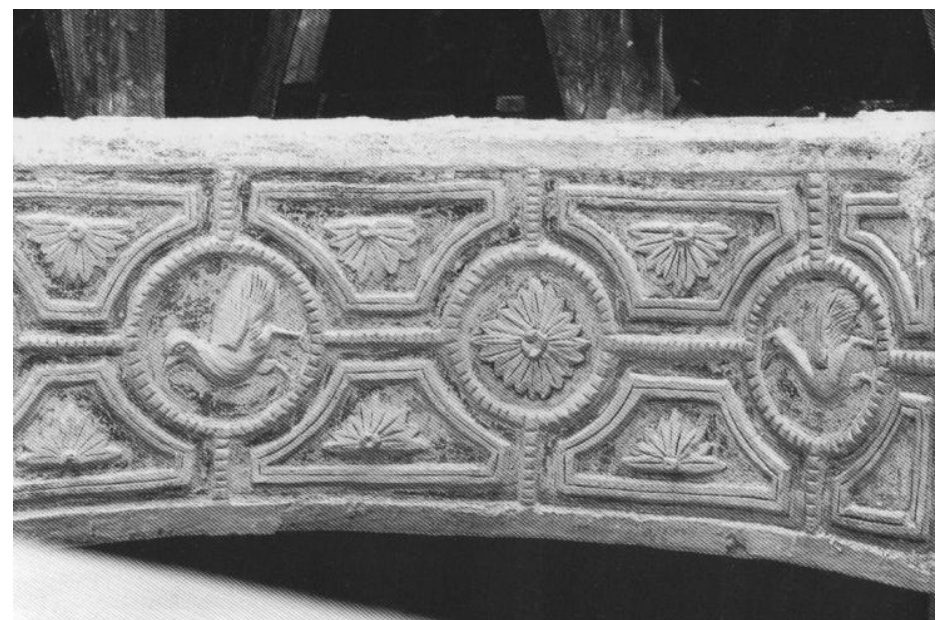

Fig. 87

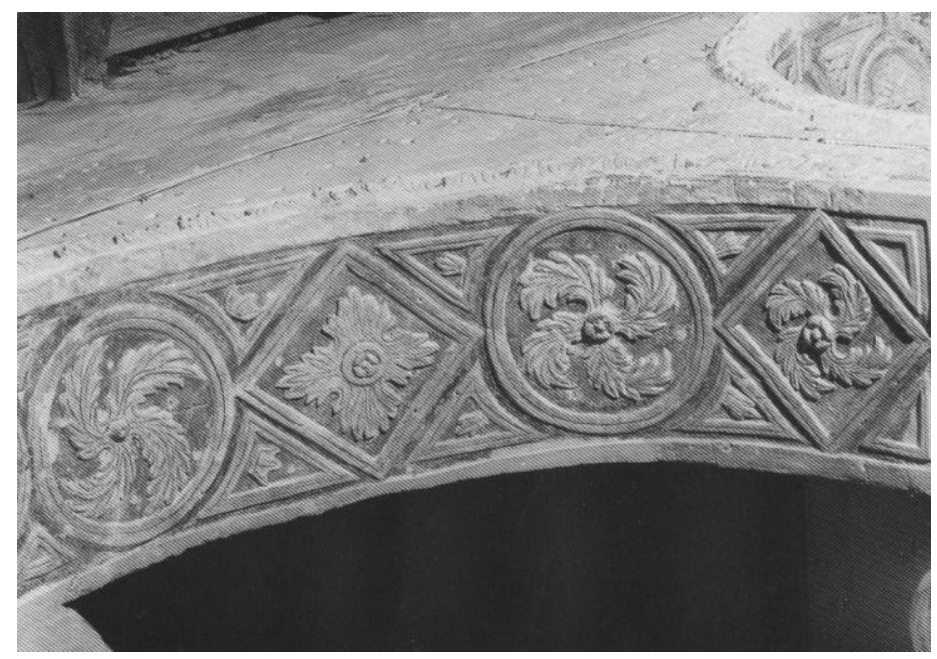

Fig. 88

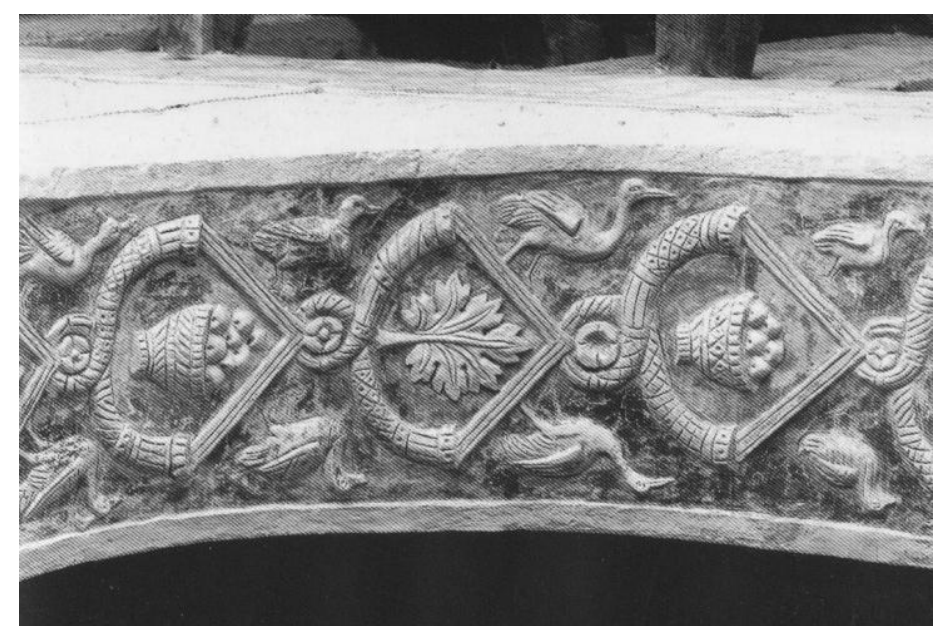

Fig. 89 


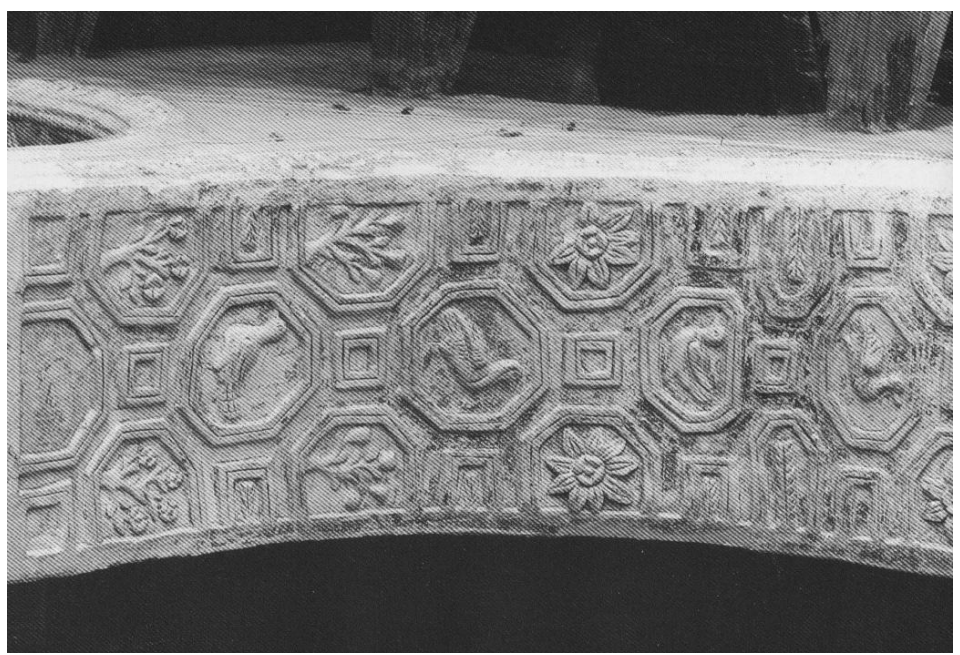

Fig. 90

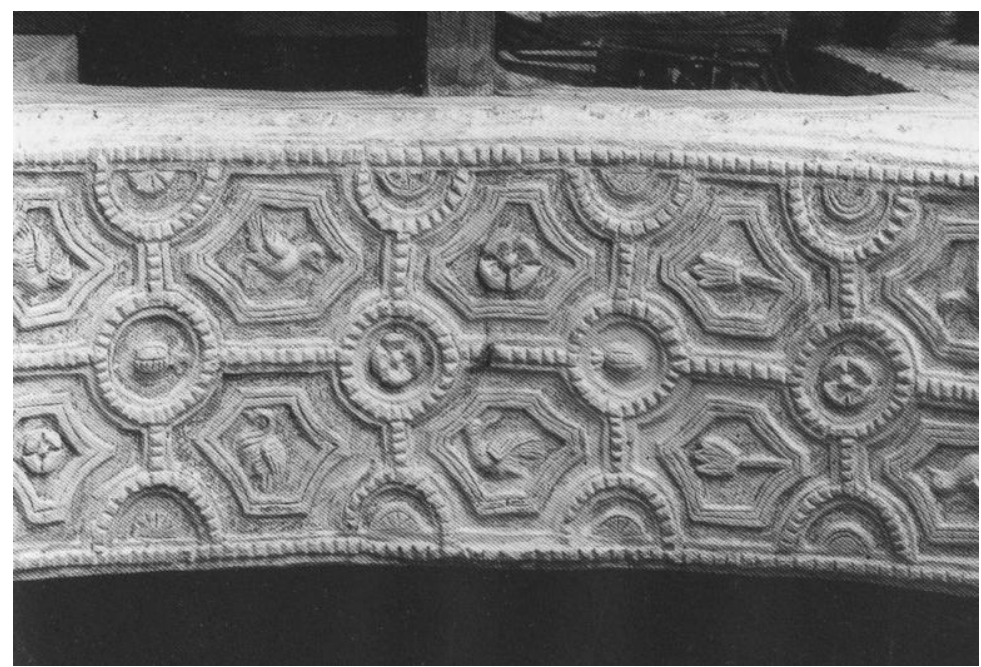

Fig. 91

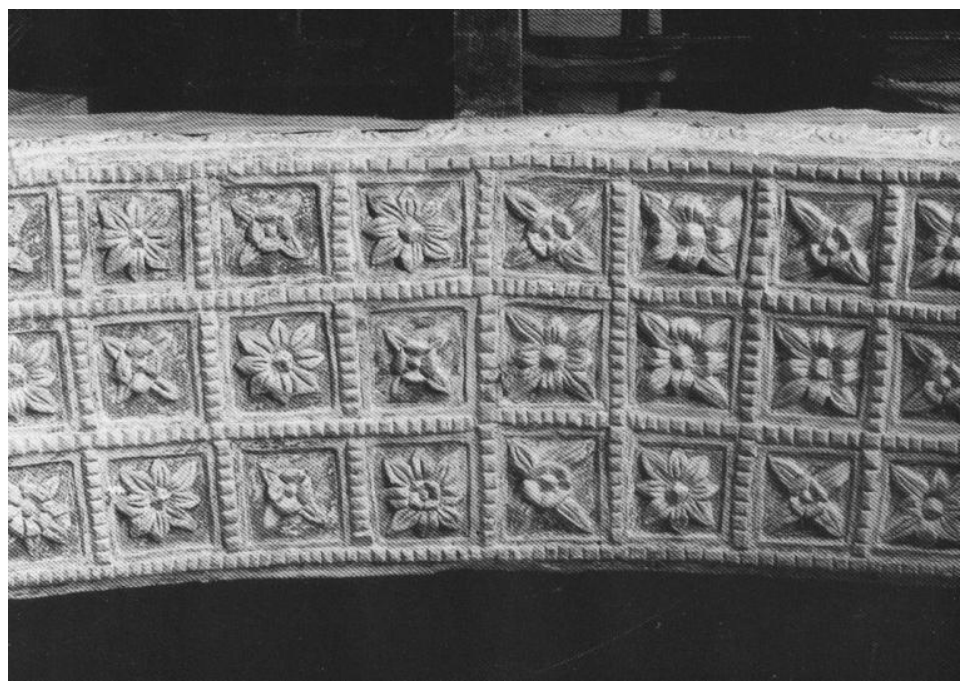

Fig. 92 


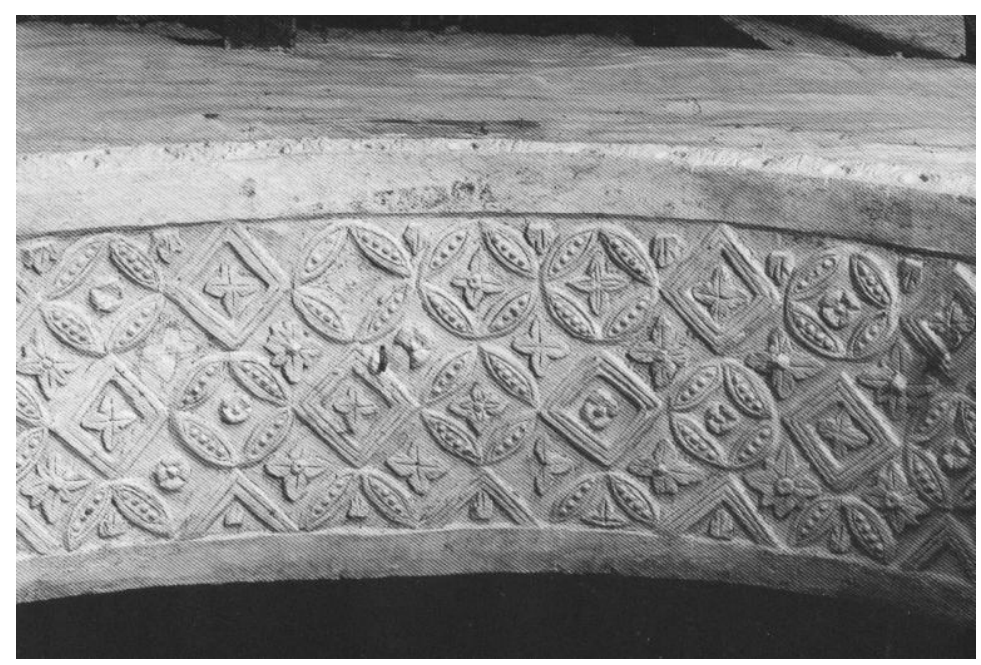

Fig. 93

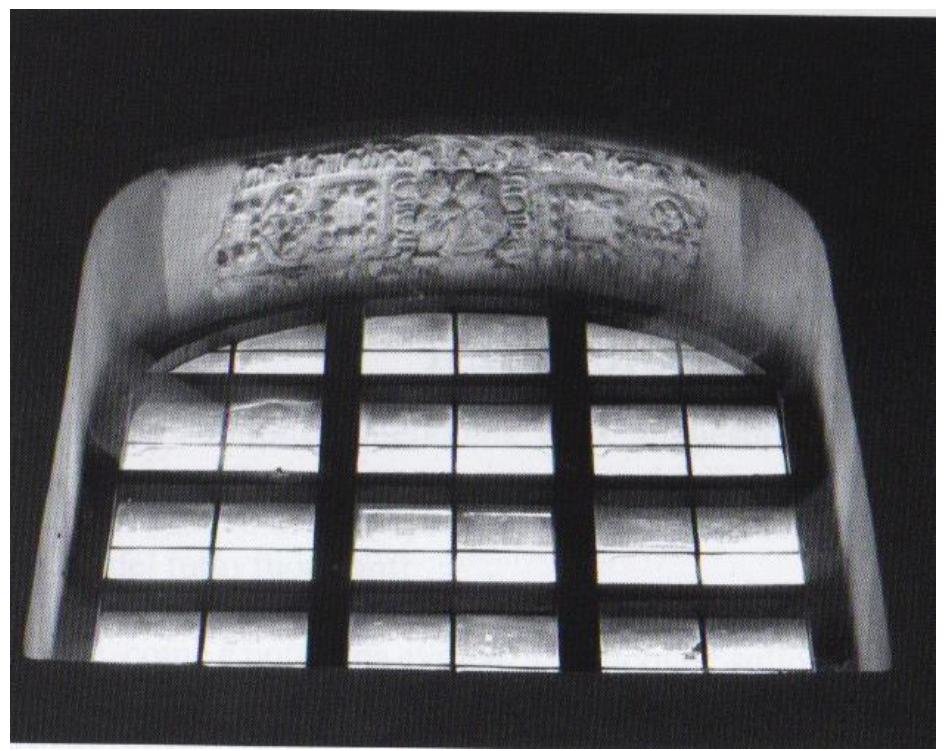

Fig. 94

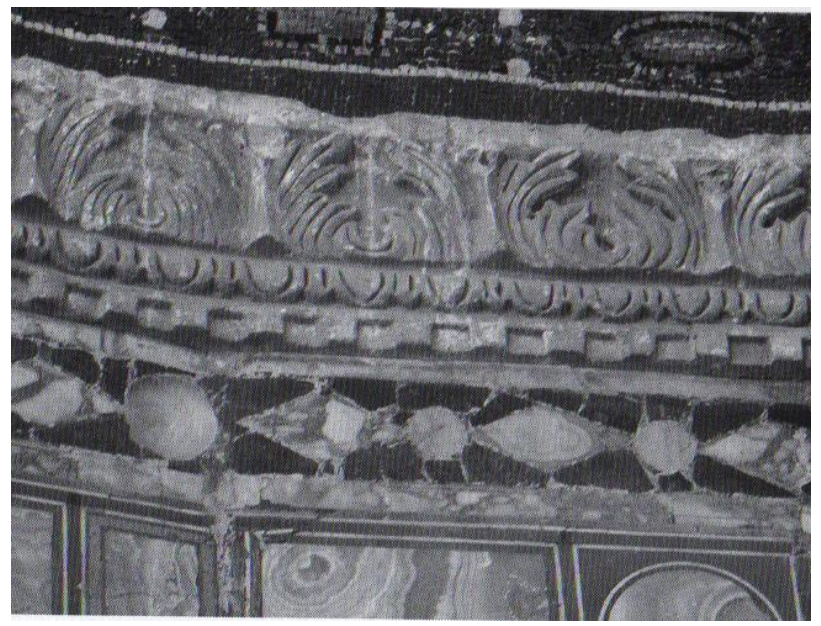

Fig. 95 

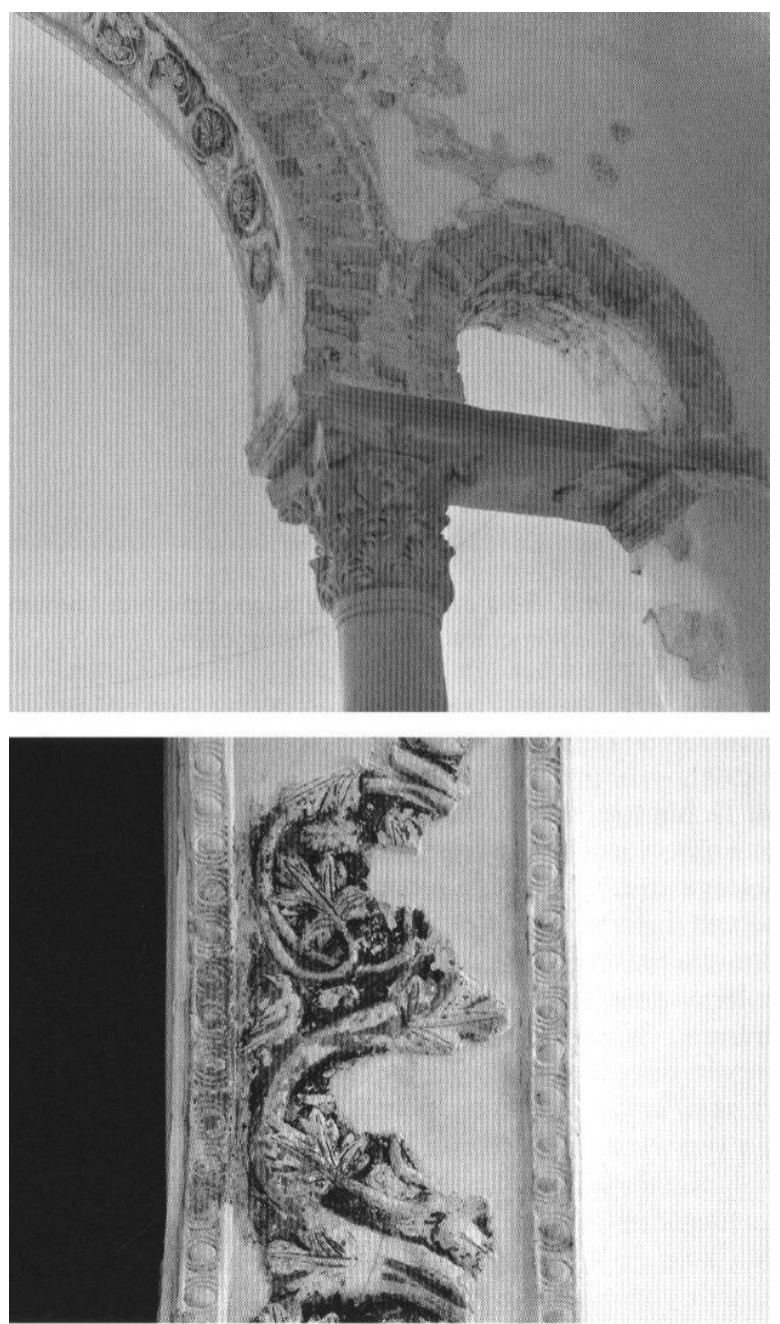

Fig. 96

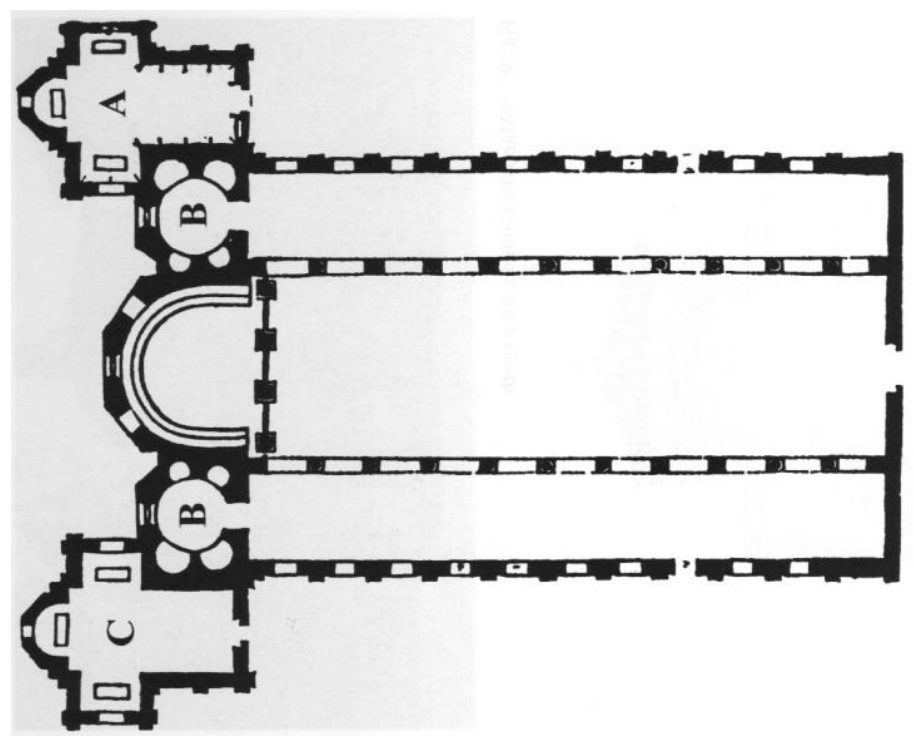

Fig. 97 


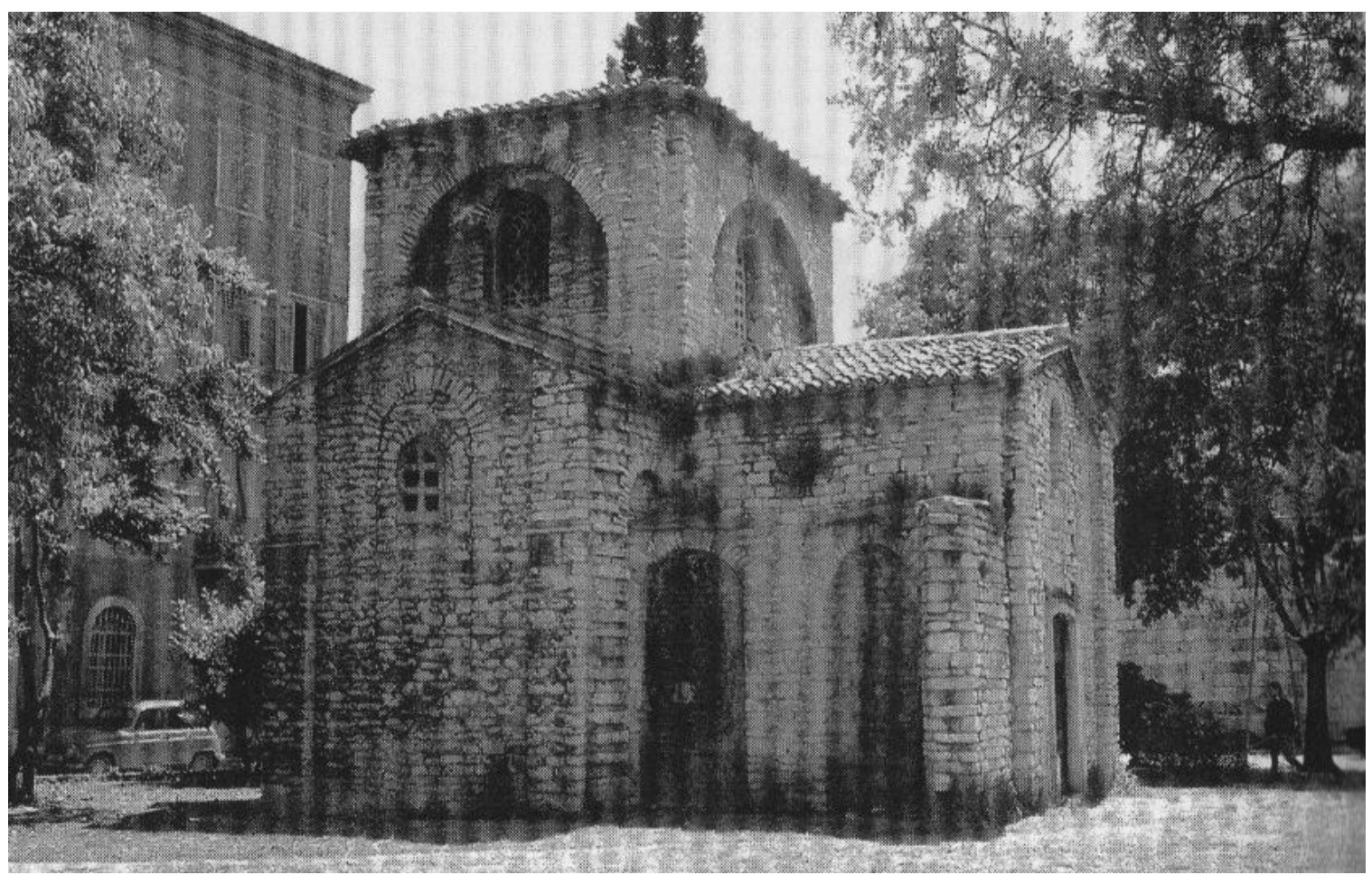

Fig. 98

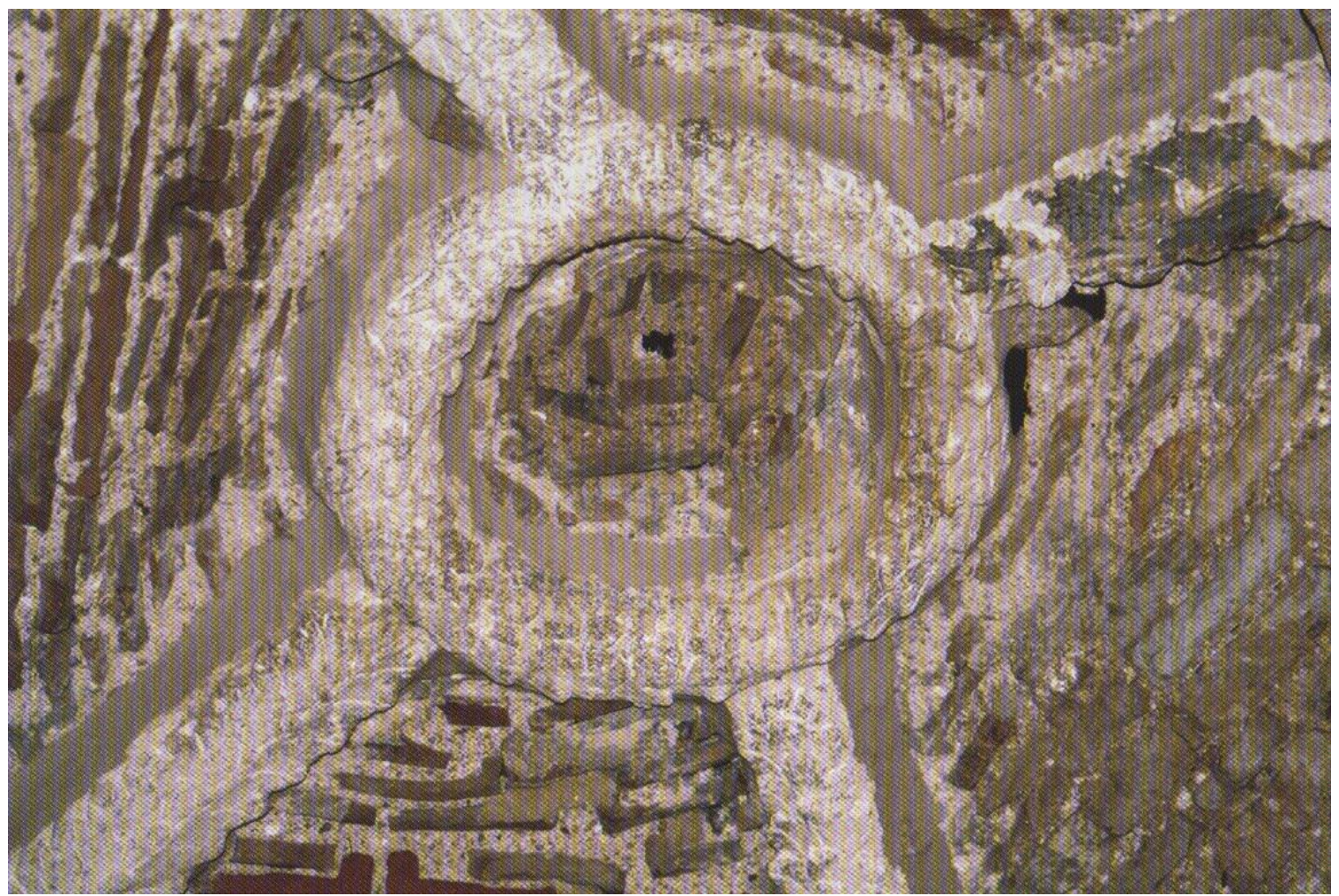

Fig. 99 


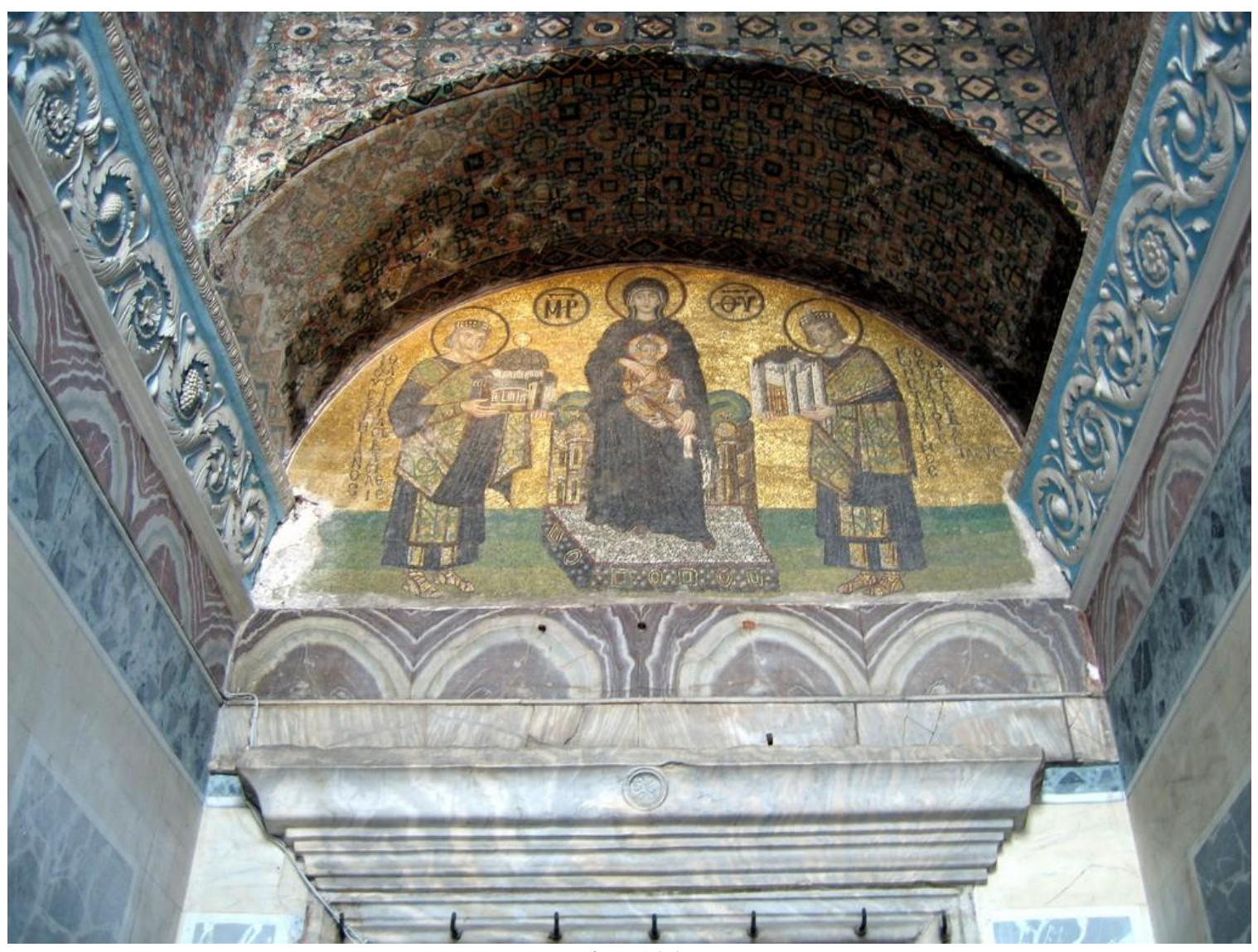

Fig. 100

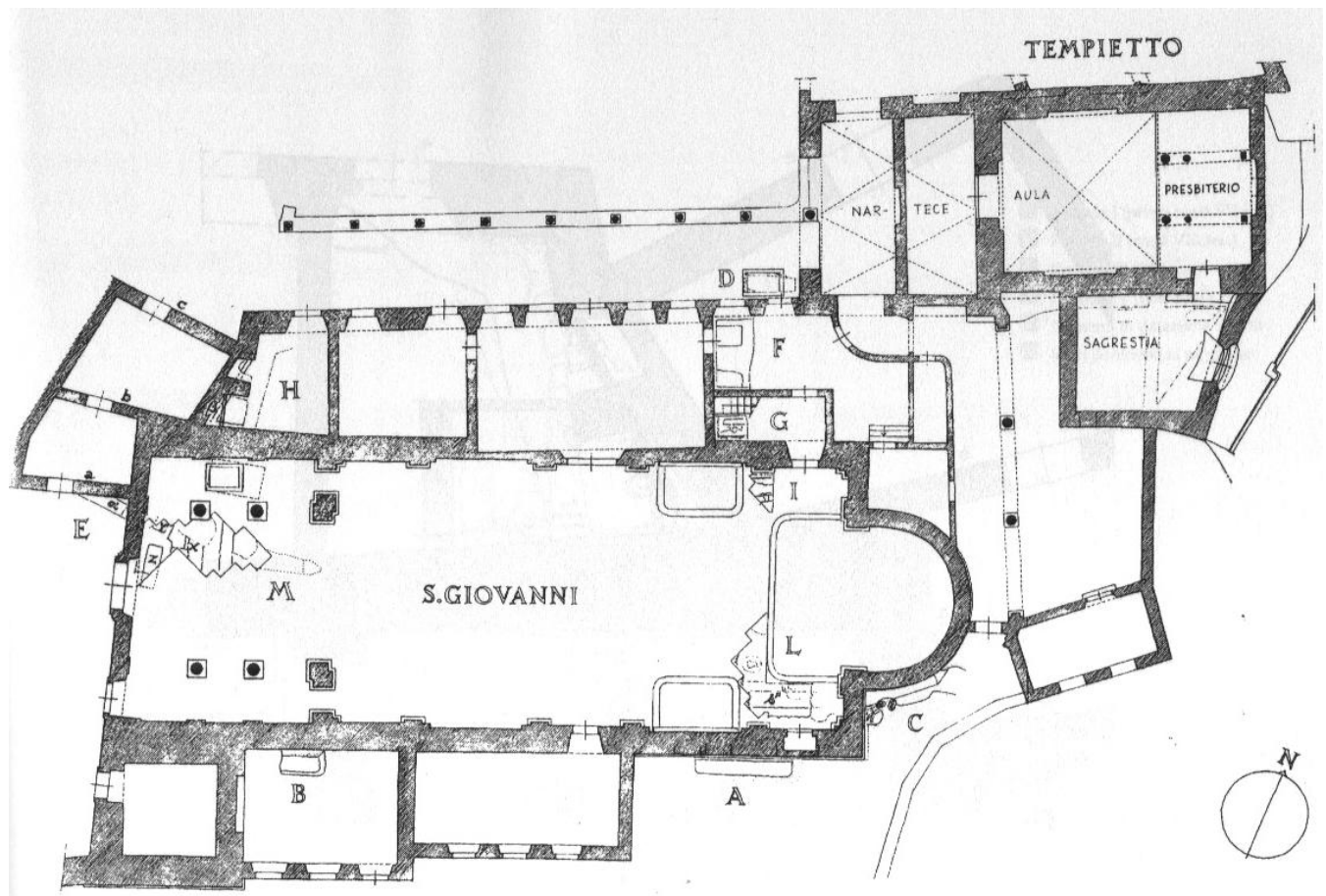

Fig. 101 


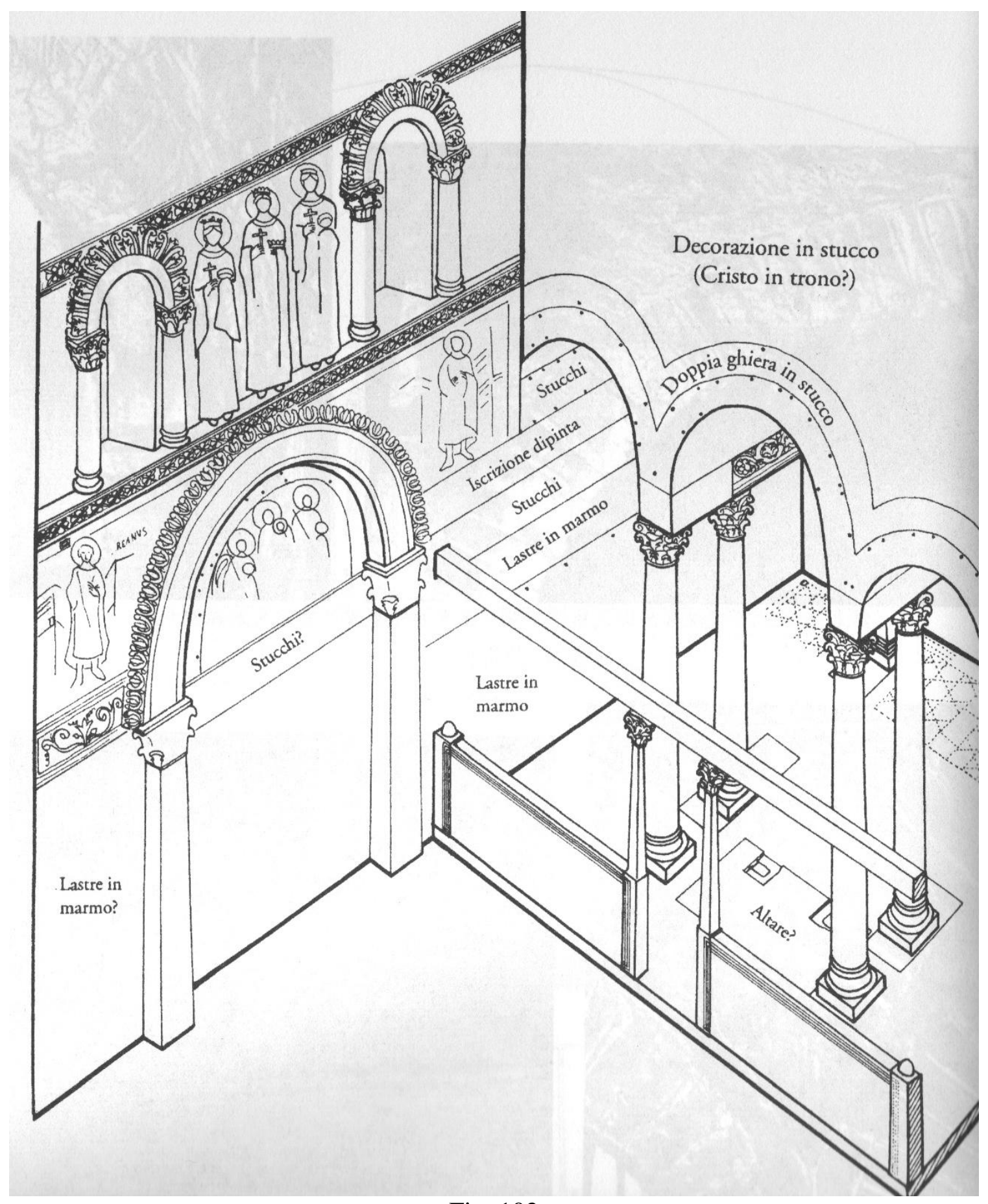

Fig. 102 


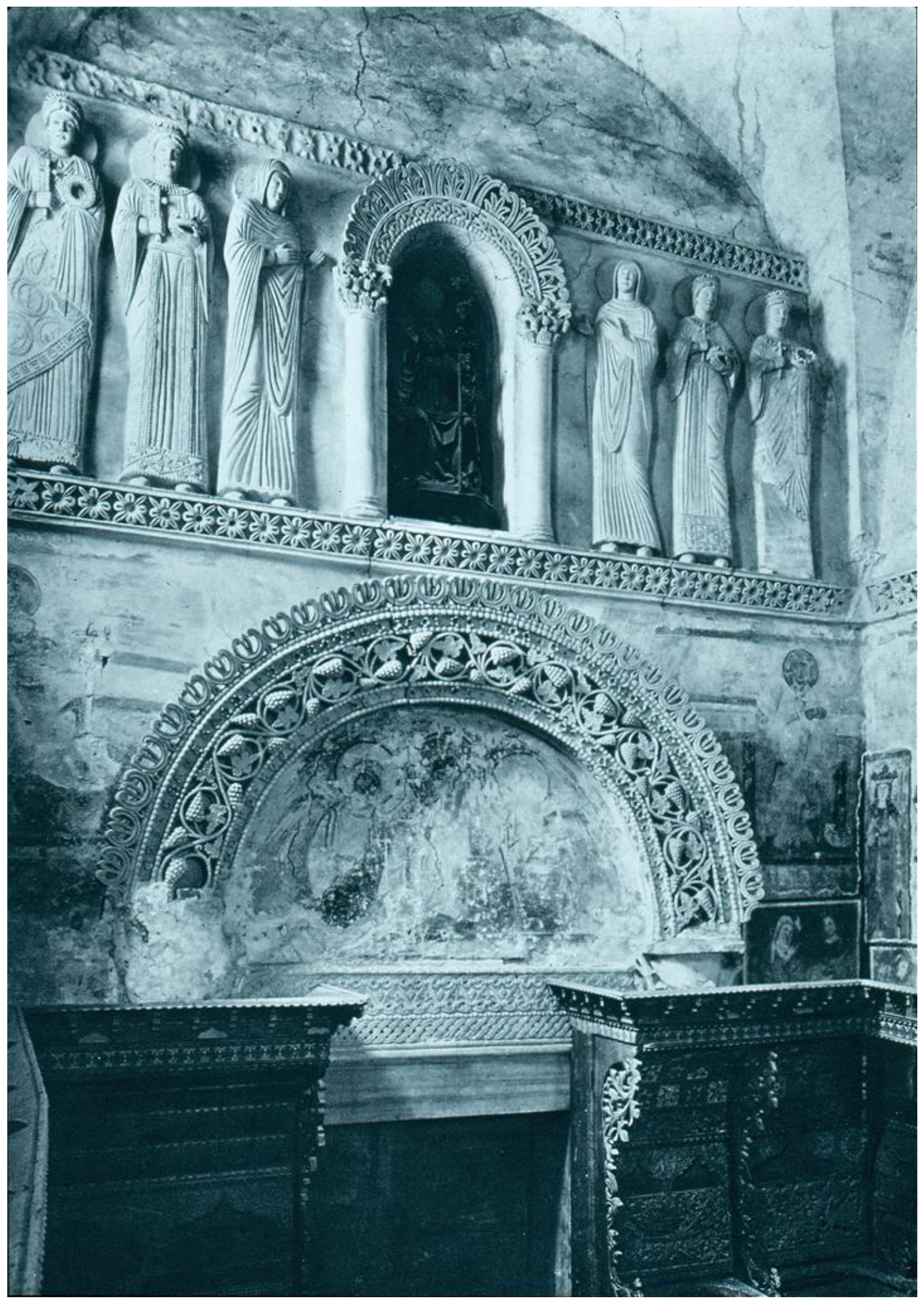

Fig. 103 


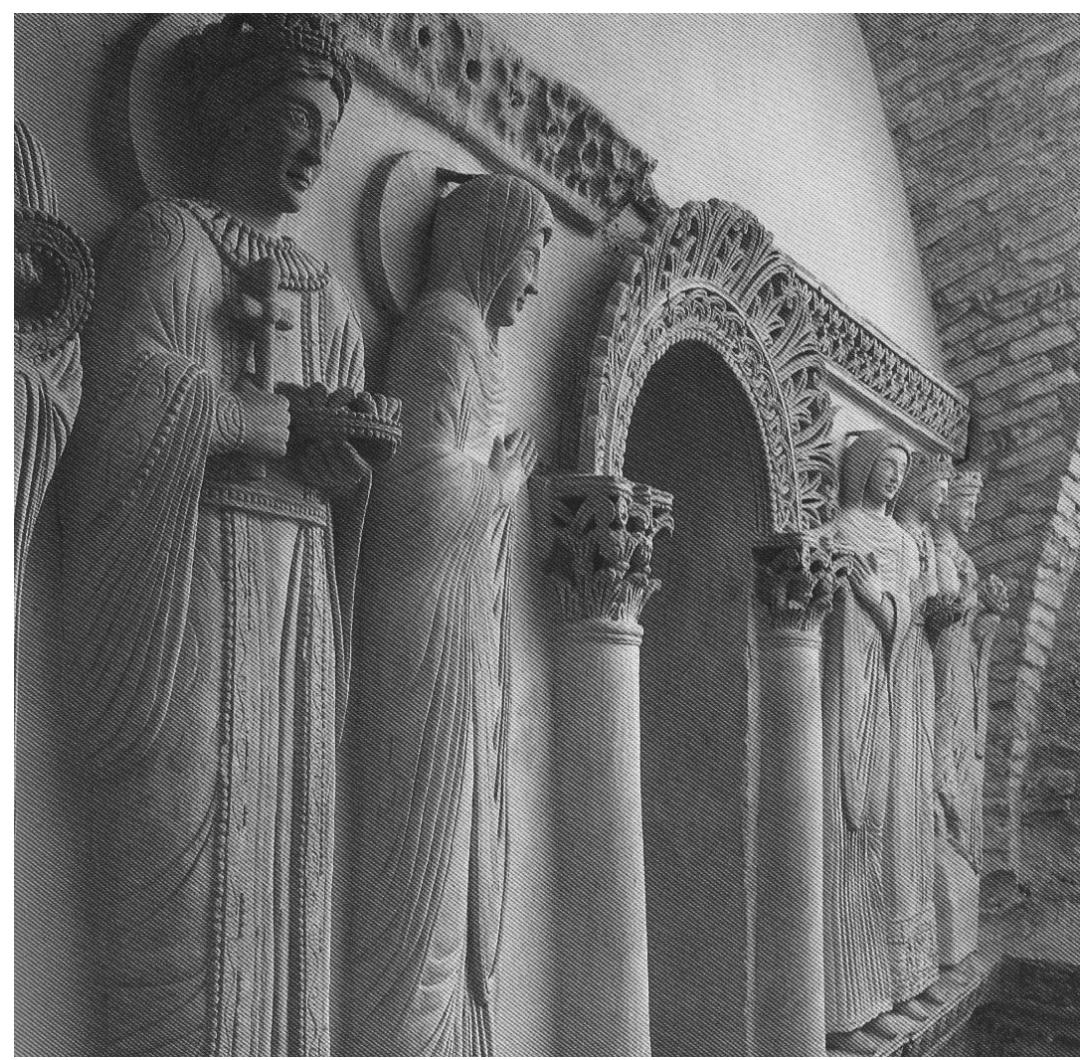

Fig. 104

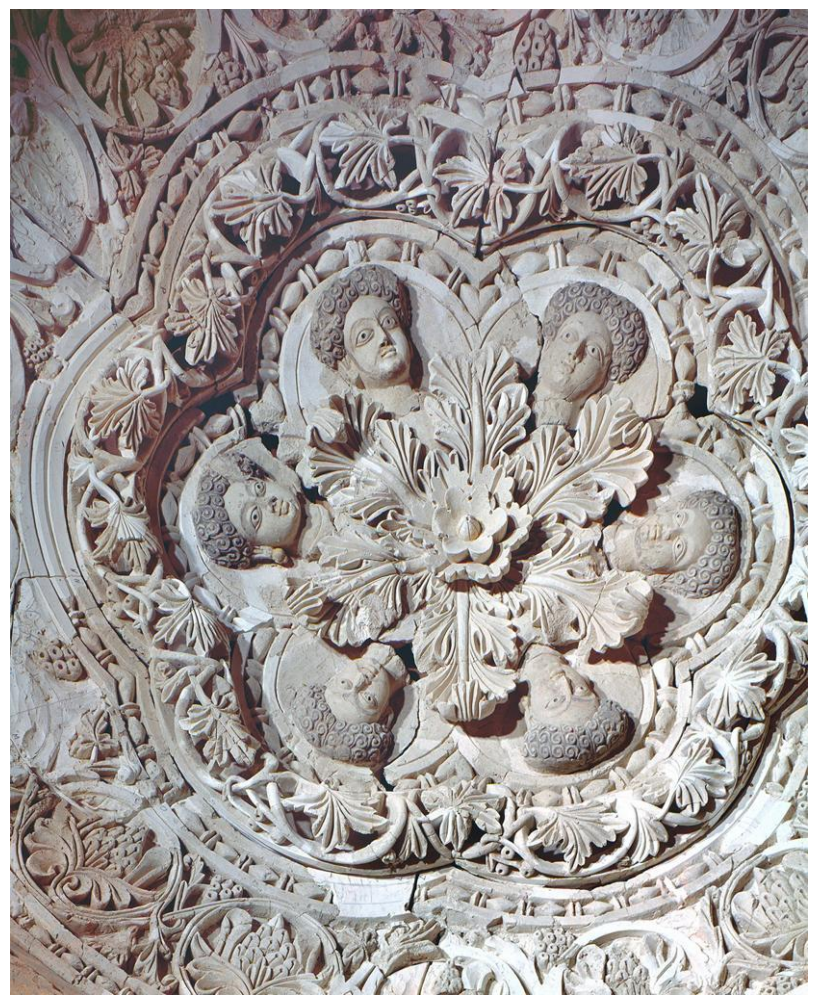

Fig. 105 


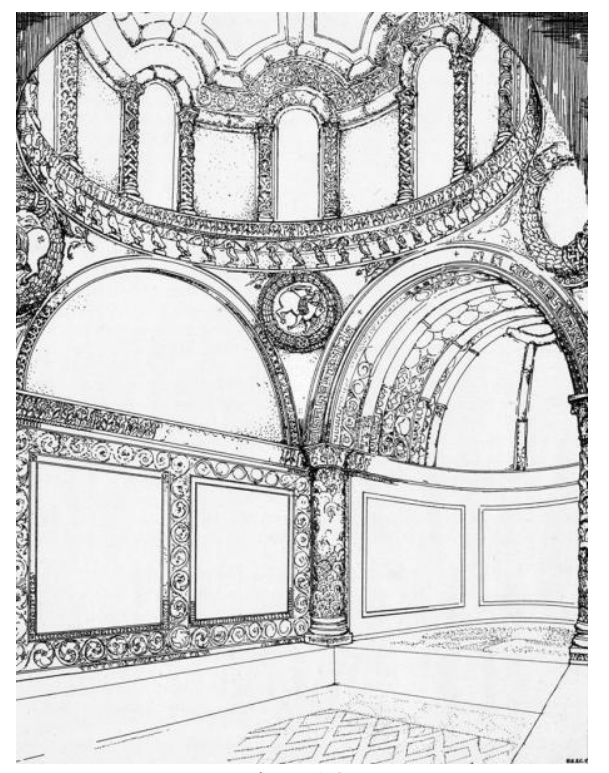

Fig. 106

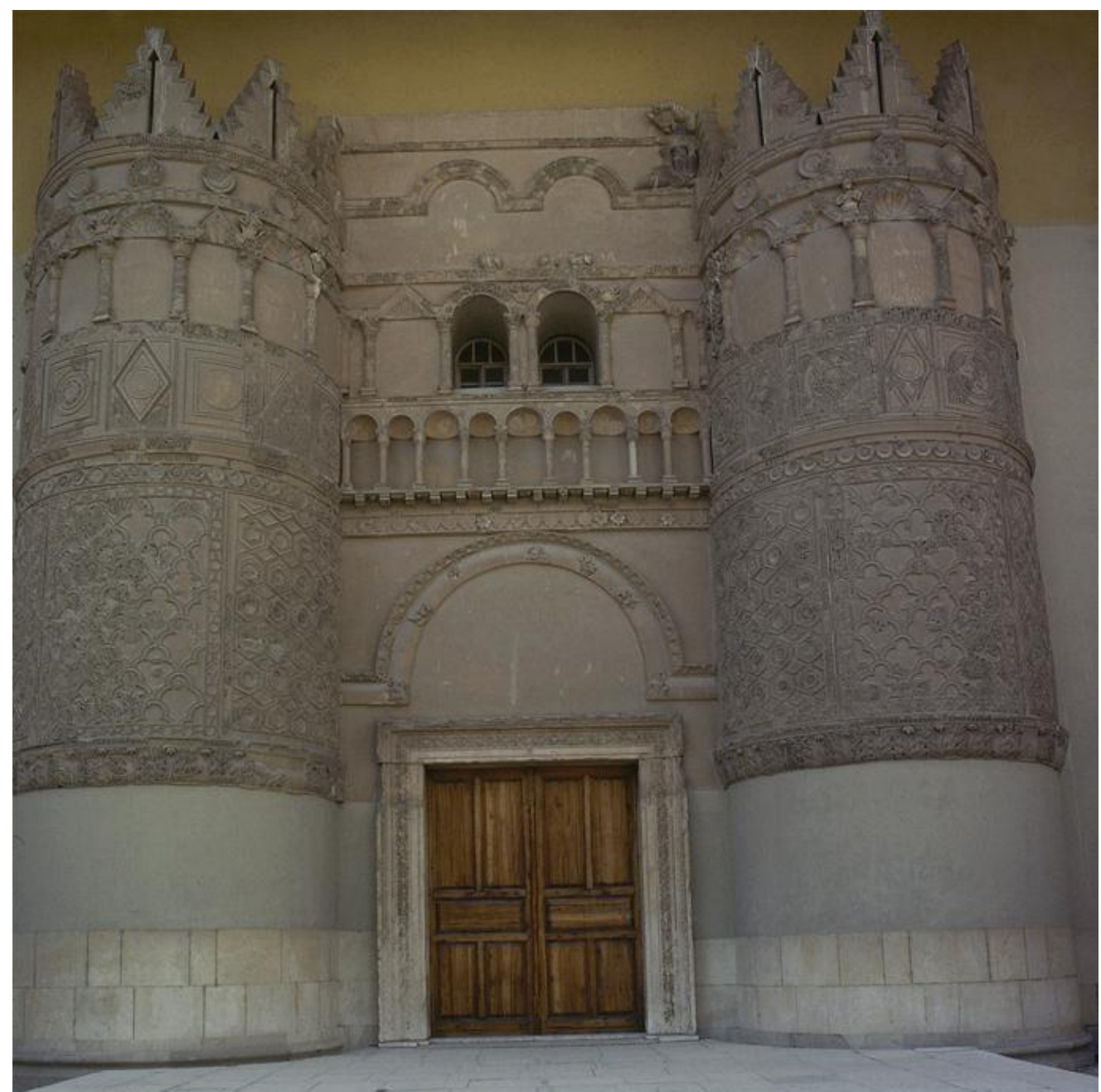

Fig. 107 


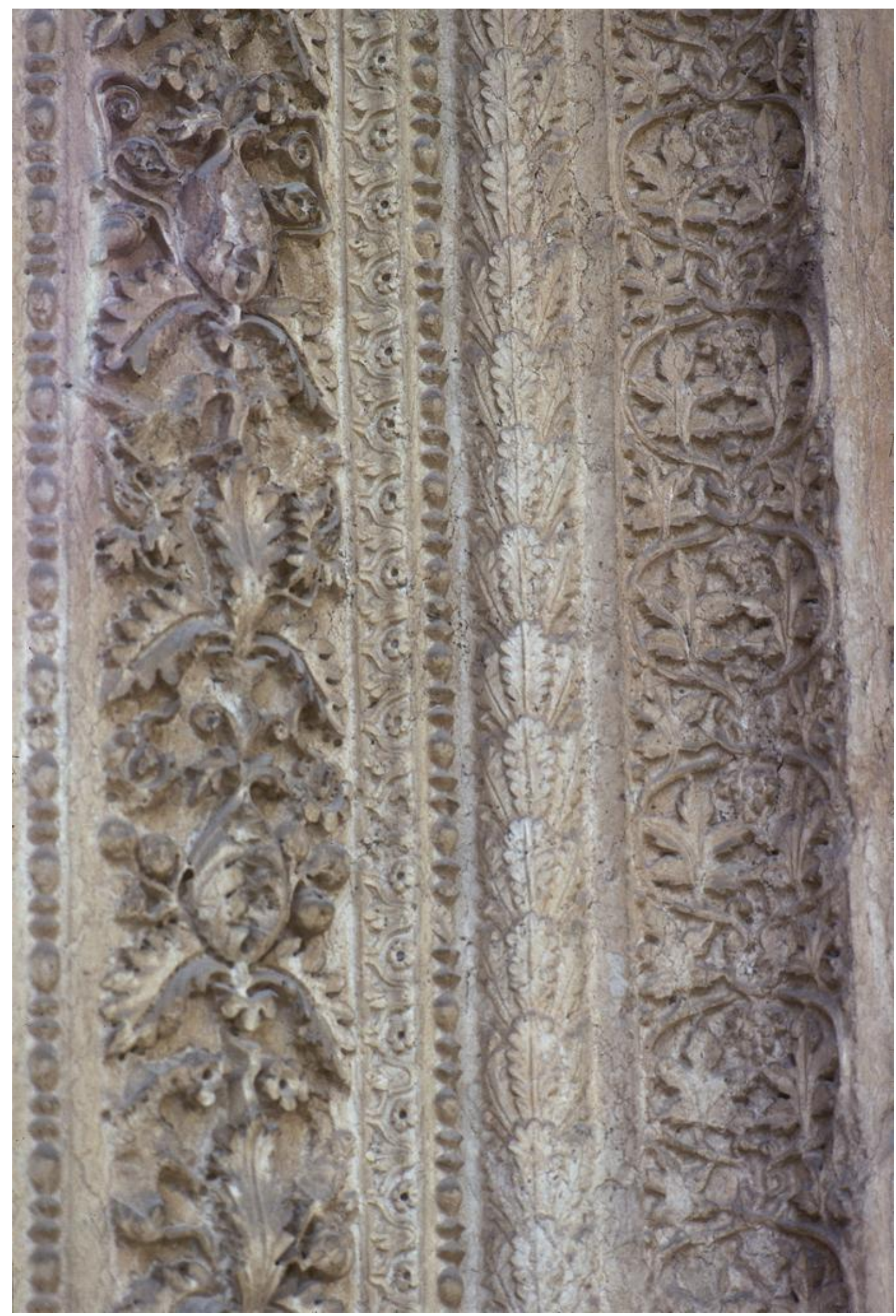

Fig. 108 


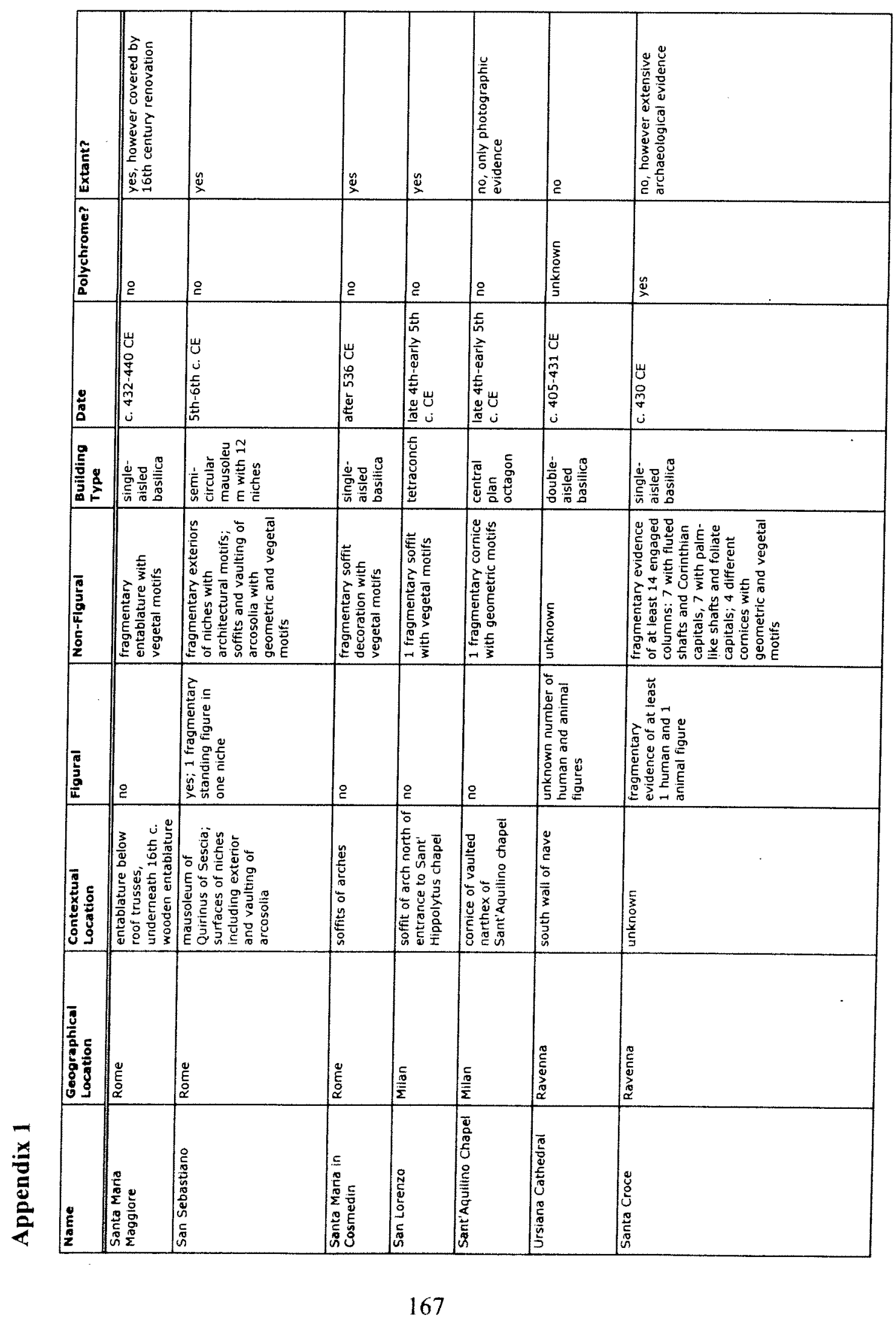




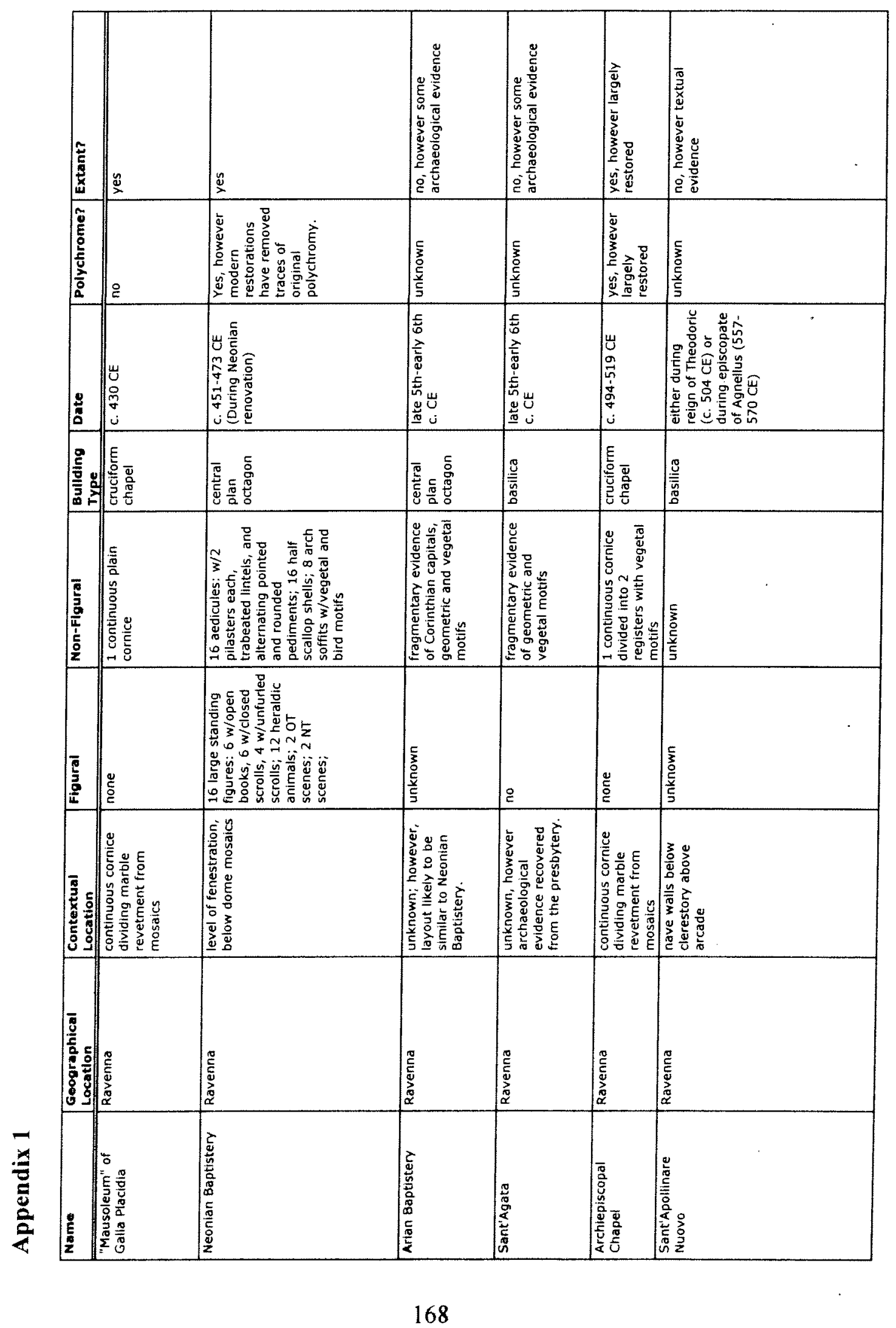




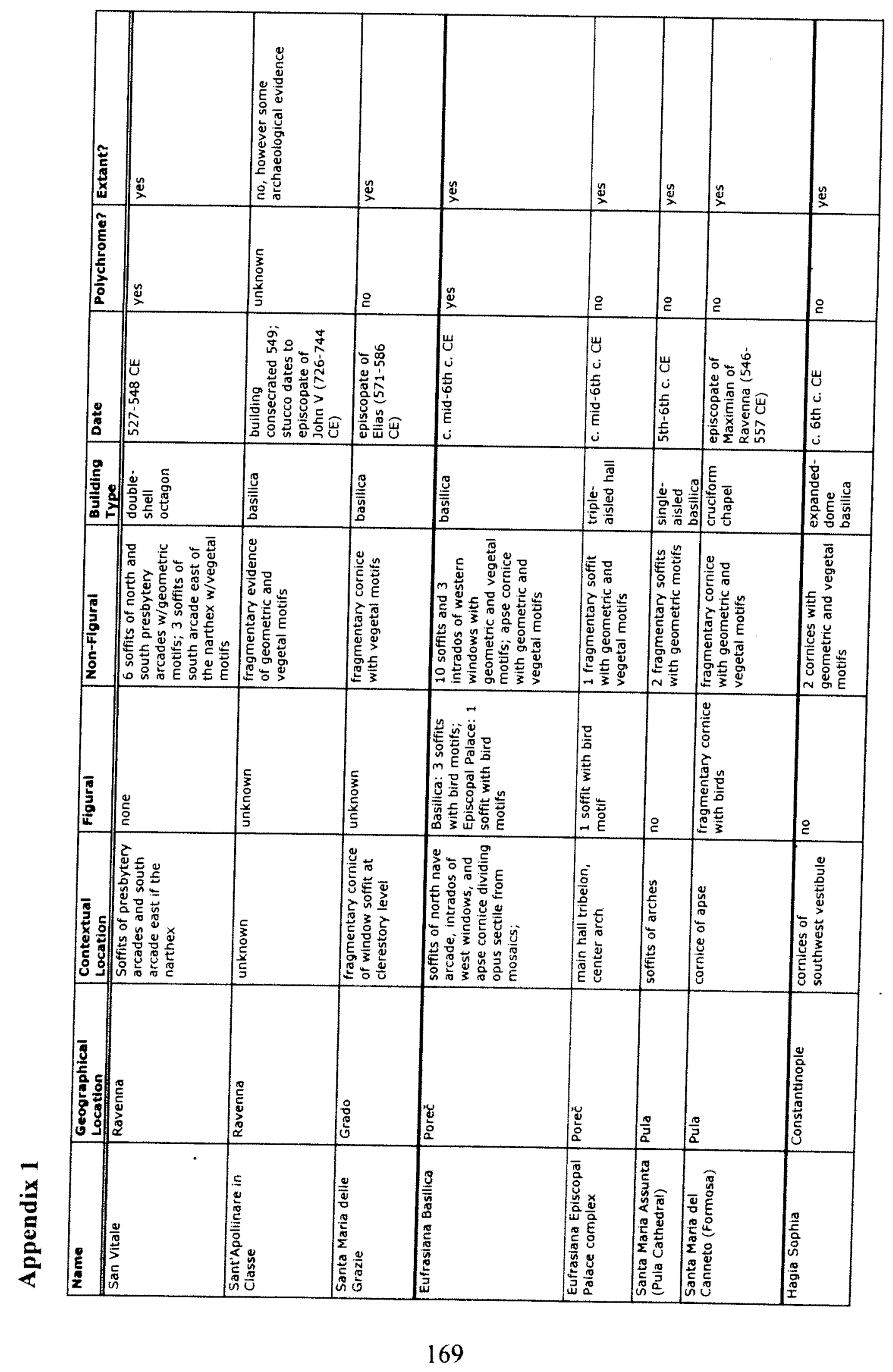




\section{CURRICULUM VITAE \\ Kaelin M. Jewell}

\section{Education:}

University of Louisville

Louisville, KY

University of Louisville

Louisville, KY
M.A. Art History

B.A. Anthropology

B.F.A. Fine Arts
2011

2006

2006

Academic Scholarships:

2010-2011

2009-2010

2008-2009
Graduate Teaching Assistantship; College of Arts \& Sciences; University of Louisville Cressman Scholarship; Hite Art Institute; University of Louisville Cressman Scholarship; Hite Art Institute; University of Louisville

Conference Presentations:

October 2010

"Architectural Vessels: The Octagonal Churches of Byzantine Palestine." Byzantine Studies Conference, Philadelphia, PA.

\section{Professional Experience:}

Hite Art Institute

University of Louisville

Hite Art Institute

University of Louisville

Visual Resources Center

University of Louisville

John Milner and Associates

Croton-on-Hudson, NY
Instructor, Ancient to Medieval Art

2010-2011

Research and Teaching Assistant for Dr. Karen Britt 2009-2010

Curatorial Assistant

2008-2009

Archaeological Field Technician

March 2007-August 2008

\section{Professional Organizations:}

Archaeological Institute of America

Byzantine Studies Association of North America

International Center of Medieval Art

College Art Association

Society of Architectural Historians
Member, 2007-present

Member, 2009-present

Member, 2010-present

Member, 2010-present

Member, 2010-present

\section{Academic References:}

Dr. Karen Britt

Dr. Blake Beattie

Dr. Linda Gigante
Assistant Professor, Art History, University of Louisville Associate Professor, History, University of Louisville Assistant Professor, Art History, University of Louisville 


\section{CURRICULUM VITAE \\ Kaelin M. Jewell}

\section{Education:}

University of Louisville

Louisville, KY

University of Louisville

Louisville, KY
M.A. Art History

B.A. Anthropology

B.F.A. Fine Arts
2011

2006

2006

Academic Scholarships:

2010-2011 Graduate Teaching Assistantship; College of Arts \& Sciences; University of Louisville 2009-2010 Cressman Scholarship; Hite Art Institute; University of Louisville

2008-2009 Cressman Scholarship; Hite Art Institute; University of Louisville

Conference Presentations:

October 2010

“Architectural Vessels: The Octagonal Churches of Byzantine Palestine.” Byzantine Studies Conference, Philadelphia, PA.

\section{Professional Experience:}

Hite Art Institute

University of Louisville

Hite Art Institute

University of Louisville

Visual Resources Center

University of Louisville

John Milner and Associates

Croton-on-Hudson, NY
Instructor, Ancient to Medieval Art

2010-2011

Research and Teaching Assistant for Dr. Karen Britt 2009-2010

Curatorial Assistant

2008-2009

Archaeological Field Technician

March 2007-August 2008

\section{Professional Organizations:}

Archaeological Institute of America

Byzantine Studies Association of North America

International Center of Medieval Art

College Art Association

Society of Architectural Historians
Member, 2007-present

Member, 2009-present

Member, 2010-present

Member, 2010-present

Member, 2010-present

\section{Academic References:}

Dr. Karen Britt

Dr. Blake Beattie

Dr. Linda Gigante
Assistant Professor, Art History, University of Louisville Associate Professor, History, University of Louisville Associate Professor, Art History, University of Louisville 